\author{
Universidade de São Paulo \\ Instituto de Química \\ Programa de Pós-Graduação em Ciências Biológicas (Bioquímica)
}

César Moisés Camilo

Regulação da expressão gênica por oxigênio no fungo aquático Blastocladiella emersonii

São Paulo

Data do Depósito na SPG

$13 / 11 / 2009$ 
César Moisés Camilo

\section{Regulação da expressão gênica por oxigênio no fungo aquático Blastocladiella emersonii}

Tese apresentada ao Instituto de Química da Universidade de São Paulo para a obtenção do título de Doutor em Ciências (Bioquímica)

Orientadora: $\operatorname{Prof}^{\mathrm{a}} \operatorname{Dr}^{\mathrm{a}}$ Suely Lopes Gomes

São Paulo 
César Moisés Camilo

Regulação da expressão gênica por oxigênio no fungo aquático Blastocladiella emersonii

Tese apresentada ao Instituto de Química da Universidade de São Paulo para a obtenção do título de Doutor em Ciências (Bioquímica)

Aprovado em:

\section{Banca Examinadora}

Prof. Dr.

Instituição:

Assinatura:

Prof. Dr.

Instituição:

Assinatura:

Prof. Dr.

Instituição:

Assinatura:

Prof. Dr.

Instituição:

Assinatura:

Prof. Dr.

Instituição:

Assinatura: 


\section{PRÓLOGO}

Por absoluto acaso, mas por ironia dele, neste ano de 2009 comemoramos os 200 anos do nascimento de Charles Robert Darwin e os 150 anos da publicação de sua mais bela obra “A Origem das Espécies”. Não quero sugerir nenhum significado cabalístico para esta data, mas fica impossível não reverenciar este que é um dos maiores pensadores que já existiram. Darwin, por meio da teoria da seleção natural, conseguiu dar uma explicação elegante e absolutamente bela a uma das questões mais intrigantes da humanidade: "De onde viemos?". Sua teoria mudou para sempre nossa visão em relação ao mundo e nosso lugar

nele, além de lançar as bases da biologia moderna, juntamente com as descobertas posteriores sobre a transmissão hereditária das características dos seres, por meio dos genes. A genialidade de Darwin não está somente em sua descoberta sobre a complexidade e diversidade da vida, mas na simplicidade de sua explicação e nas evidências gritantes que ele encontrou em sua viagem a bordo do HMS Beagle. Tanto foi genial sua teoria, que conseguiu se perpetuar em uma época em que os mitos religiosos de criação divina tinham extrema influência, até mesmo no meio científico. Darwin iluminou o mundo provando que não somos seres perfeitos criados por entidades sobrenaturais. $\mathrm{Na}$ verdade, somos seres vencedores que graças à adaptação de nossos antepassados mais distantes, gozamos de um momento único e fantasticamente supremo - a vida.

"Eu estou quase convencido de que (completamente contrário à opinião de quando comecei) as espécies não são (e isso é tal como uma confissão de um assassinato) imutáveis." 


\section{AGRADECIMENTOS}

À Prof ${ }^{\mathrm{a}}$. Dra. Suely Lopes Gomes, por confiar no meu trabalho e me proporcionar todas as condições para desenvolver minha pesquisa. Sua seriedade e zelo com que trata o patrimônio público é algo que deveria ser copiado e que levarei comigo para sempre.

Ao Prof. Dr. Hamza El-Dorry e todos os amigos de seu antigo laboratório, Wilton, Zilda, Marluce, Erik, Augusto, Eric, Ari e Inês.

Ao Prof. Dr. Felipe Chambergo pela amizade, parceria e discussões durante todo meu doutorado e iniciação científica.

À CAPES, CNPq e FAPESP, pelo apoio financeiro.

Aos amigos do laboratório André Vieira, Rogério Lourenço, Gabriela Mol, Raphaela Georg, Karina Ribichich, Michelle Suzin, Christian Kohler, Anne Krause, Ricardo Vêncio, Tie Koide, Luci Navarro, Sandra Mara e Ivone Pereira, pela amizade, trabalho em equipe e ajudas imprescindíveis para a realização desse trabalho.

À Prof ${ }^{a}$. Dra. Regina Baldini e seus alunos Ana Laura, Eliezer, Diogo, Gianlucca, Ana Paula, Patrícia e Gilberto, por tornarem a rotina no laboratório sempre agradável.

À Denise Yamamoto, pelo apoio técnico durante os experimentos de microarranjo e pelas divertidas conversas.

Aos colegas da Secretaria de Pós-Graduação pela ajuda e agilidade.

Ao Prof. Dr. Etelvino Bechara, ao Prof. Dr. Nilson Assunção e suas alunas de iniciação científica Adriana, Cecilia e Ana, pela realização das análises metabolômicas por Eletroforese Capilar.

Aos meus amigos da Rep. Pasquote e da Rep. Pablito: Otávio, Jairo, Pedro, Diego e Gordz, por tudo aquilo que não diz respeito a trabalho na vida acadêmica.

Aos meus amigões do peito Jão, Rita, Rafa, Rê, Careca, Ligera, Regina, Northon, Brunão, Lucas, Gui, Heid, Flaviona, Flavinha, Tabata e Talissa, pela valiosa e sincera amizade de sempre. 
À Fabiana, que me fez superar todos os momentos difíceis deste trabalho e por ser uma pessoa tão maravilhosa com quem tenho o prazer de compartilhar minha vida. E é claro a toda sua família, Mariângela, Sérgio, Marina e Renata, que sempre me apoiaram em tudo.

Aos meus irmãos Thales e Luciana, companheiros de todas as horas.

Aos meus pais, Ciro e Beth, meus agradecimentos vão muito além desta tese. Toda uma vida de exemplos, dedicação e ensinamentos é prova de verdadeiro amor incondicional que me faz um imenso nó na garganta. Além de matarem um leão por dia para que eu e meus irmãos pudéssemos estudar, fizeram de nossa casa um ambiente de inúmeros estímulos à cultura, ao esporte e à ciência, sem os quais dificilmente estaria defendendo uma tese de doutorado.

É com imensa gratidão que dedico esta tese aos meus pais. 


\section{RESUMO}

Camilo, C.M. Regulação da expressão gênica por oxigênio no fungo aquático Blastocladiella emersonii. 2009. 140 p. Tese (Doutorado) - Programa de Pós-Graduação em Bioquímica. Instituto de Química, Universidade de São Paulo, São Paulo.

Neste trabalho realizamos a análise das variações na expressão gênica global do fungo aquático Blastocladiella emersonii submetido ao estresse de carência de oxigênio (hipóxia), utilizando a técnica de microarranjos de cDNA em lâminas contendo 3773 genes distintos. Nos experimentos de hipóxia gradual (diminuição gradual da concentração de oxigênio dissolvido, seguido de reoxigenação) e hipóxia direta (diminuição direta da concentração de oxigênio dissolvido, seguido de reoxigenação) observamos que 650 genes foram diferencialmente expressos em pelo menos uma das condições de estresse e que 534 deles mostraram-se afetados (direta ou indiretamente) pela disponibilidade de oxigênio, uma vez que apresentaram recuperação (ou tendência à recuperação) da sua expressão aos níveis normais, quando as células foram reoxigenadas. Além de modular a expressão de diversos genes sem função conhecida, $B$. emersonii responde à hipóxia reajustando a expressão de genes responsáveis pela produção e consumo de energia. Pelo menos transcricionalmente, este fungo favorece o metabolismo anaeróbico, através da indução de genes que codificam enzimas da via glicolítica e lactato desidrogenase, ao passo que no ciclo do ácido cítrico, a maioria dos genes encontram-se reprimidos ou não sofrem alteração na expressão. Processos dispendiosos em energia como síntese protéica, metabolismo de aminoácidos, enovelamento de proteínas e transporte por membrana apresentaram perfis predominantemente de repressão gênica quando em carência de oxigênio. Ainda utilizando a técnica de microarranjos, mostramos semelhanças entre os perfis transcricionais nos experimentos hipóxia e de carência de $\mathrm{Fe}^{2+}$ (tratamento com quelante de $\mathrm{Fe}^{2+} 2,2^{\prime}$-dipyridyl) sugerem que estes estresses estão de alguma forma relacionados, fornecendo bons indícios de que o íon $\mathrm{Fe}^{2+}$ possa ter um papel importante no mecanismo sensor de oxigênio e/ou de resposta a hipóxia em $B$. emersonii. Além disso, o tratamento prévio de células submetidas à hipóxia com o antibiótico geldanamicina, um conhecido inibidor da proteína de choque térmico HSP90, levou à diminuição da indução de certos genes de hipóxia, indicando que este fungo pode possuir algum mecanismo semelhante ao do fator de transcrição de hipóxia HIF1- $\alpha$ de mamíferos, uma vez que este fator também é afetado por geldanamicina. Adicionalmente, desenvolvemos um protocolo para transformação de $B$. emersonii mediada por Agrobacterium tumefasciens que se mostrou promissor. A transferência do T-DNA contendo um gene de resistência a higromicina $\mathrm{B}$, presente no vetor binário pBINPLUS-Hph, foi evidenciada pelo crescimento normal e esporulação das células transformadas, na presença do antibiótico e pela amplificação do gene de resistência no DNA genômico de células transformadas.

Palavras-chave: fungo aquático, microarranjos de cDNA, hipóxia, expressão gênica 


\section{ABSTRACT}

Camilo, C.M. Regulation of gene expression by oxygen in the aquatic fungus Blastocladiella emersonii. 2009. 140 p. PhD Thesis - Graduate Program in Biochemistry. Instituto de Química, Universidade de São Paulo, São Paulo.

In this work we analyzed global gene expression changes in the aquatic fungus Blastocladiella emersonii submitted to oxygen deprivation (hypoxia), using cDNA microarrays containing 3,773 distinct genes. In gradual hypoxia (gradual decrease in dissolved oxygen concentration, followed by reoxygenation) and direct hypoxia (direct decrease of dissolved oxygen concentration, followed by reoxygenation) we observed 650 differentially expressed genes in at least one of the stress conditions tested, 534 of them being affected (directly or indirectly) by oxygen availability, since they showed recovery of normal expression levels or a tendency to recover, when cells were reoxygenated. Besides modulating many genes with no previously assigned function, $B$. emersonii responds to hypoxia by readjusting the expression levels of genes responsible for energy production and consumption. At least transcriptionally, this fungus seems to favour anaerobic metabolism through the induction of genes encoding glycolytic enzymes and lactate dehydrogenase, while in the TCA-cycle, most genes were repressed or unchanged. Energy-costly processes like protein synthesis, amino acid metabolism, protein folding and transport had their gene expression profiles predominantly repressed during oxygen deprivation. Microarray experiments also showed similarities between the transcriptional profile of genes in hypoxia and iron (II) deprivation (treatment with the iron (II) chelator 2,2'-dipyridyl), suggesting that these stresses are somehow related, giving good evidence that $\mathrm{Fe}^{2+}$ ion could have a role in the mechanism of oxygen sensing and/or response to hypoxia in B. emersonii. Furthermore, pretreatment of cells subjected to hypoxia with the antibiotic geldanamycin, a known inhibitor of the heat shock protein HSP90, caused a significant decrease in the induction of certain hypoxic genes, indicating that this fungus could have a mechanism similar to that of the mammalian hypoxia transcription factor HIF-1 $\alpha$, which is also affected by geldanamycin. Additionally, we developed an Agrobacterium tumefasciens-mediated protocol for transformation of $B$. emersonii that has shown to be promising. The capacity to transfer the T-DNA containing a hygromycin B resistance gene, present in the pBINPLUSHph binary vector, was evidenced by the normal growth and sporulation of the transformed cells in the presence of antibiotic and by amplification of the resistance gene from the genomic DNA of transformed cells.

Keywords: aquatic fungus, cDNA microarray, hypoxia, gene expression 


\section{SUMÁRIO}

LISTA DE FIGURAS

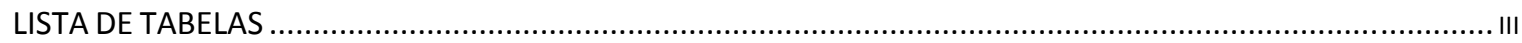

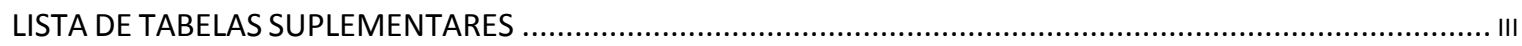

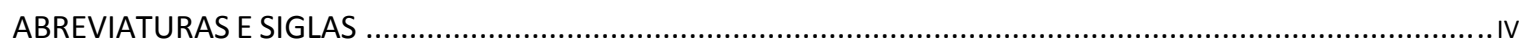

1 INTRODUÇÃO

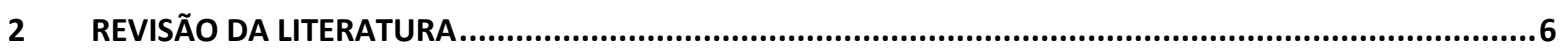

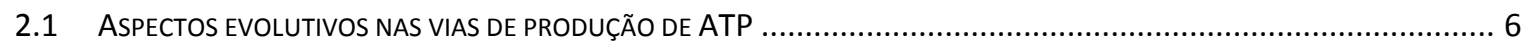

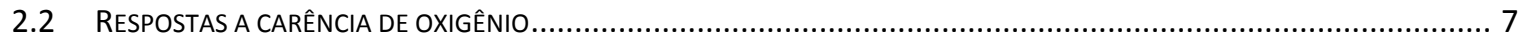

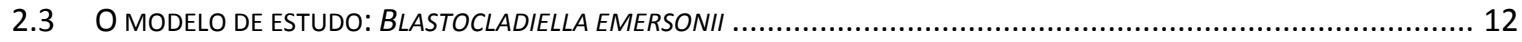

2.4 ESTUdos METABolôMICOS UTILIZANDO A TÉCNICA DE ELETROFORESE CAPILAR .................................................. 17

2.5 TRANSFORMAÇÃO DE EUCARIOTOS MEDIADA POR AGROBACTERIUM TUMEFASCIENS .......................................... 19

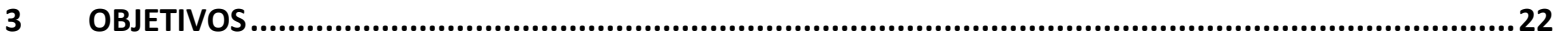

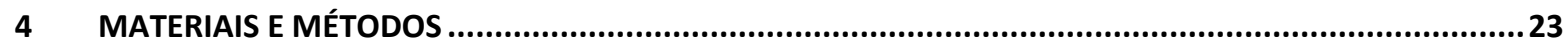

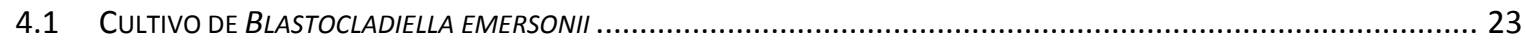

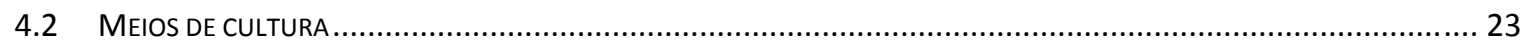

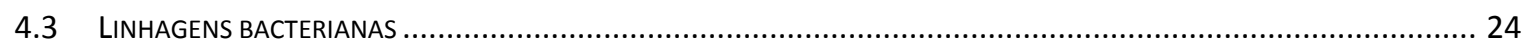

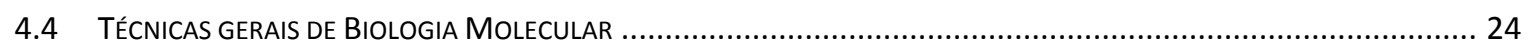

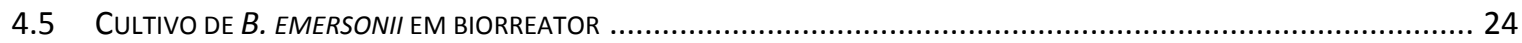

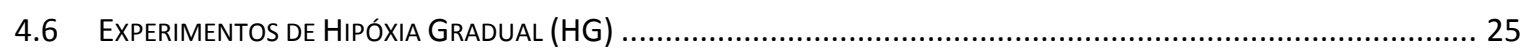

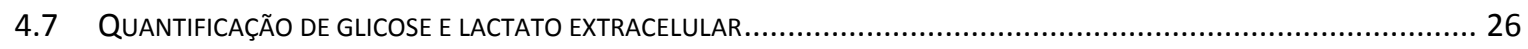

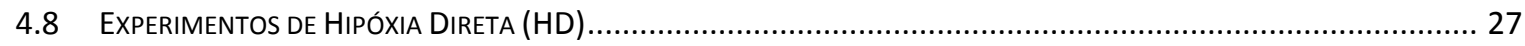

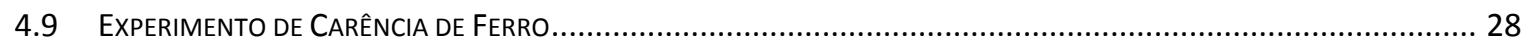

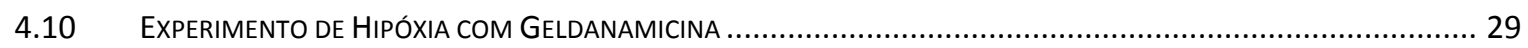

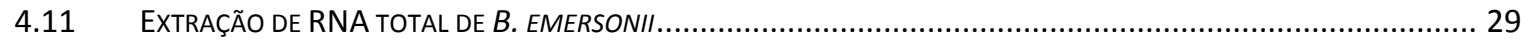

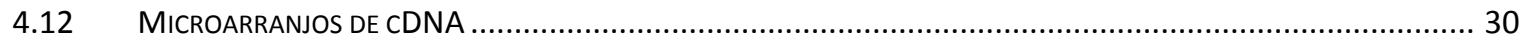

4.12.1 Síntese de cDNA e marcação com fluoróforo para hibridização dos microarranjos.............. 30 
4.12.2 Hibridização e leitura da fluorescência das lâminas de microarranjos................................ 31

4.12.3 Quantificação da fluorescência emitida nos microarranjos e extração dos dados ............... 33

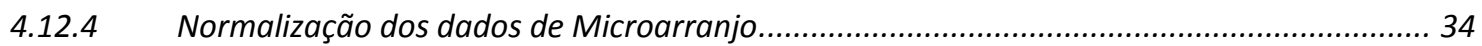

4.12.5 Determinação dos genes diferencialmente expressos................................................. 34

4.12.6 Agrupamento dos genes diferencialmente expressos segundo o perfil de expressão........... 37

4.12.7 Determinação das categorias do Consórcio Gene Ontology mais representadas entre os genes diferencialmente expressos

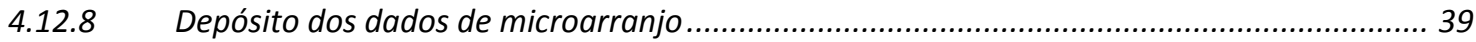

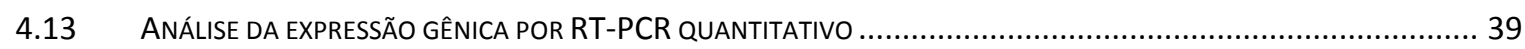

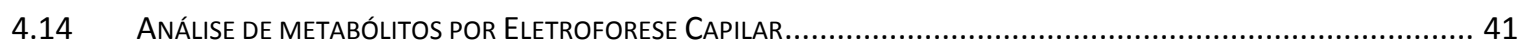

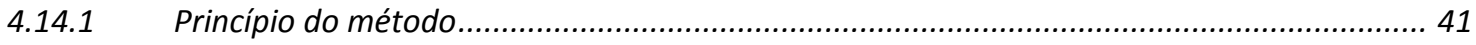

4.14.2 Análise de metabólitos catiônicos por CE-MS......................................................... 41

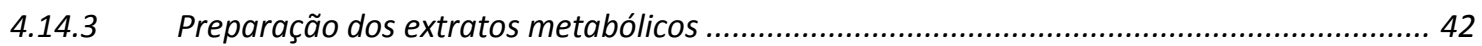

4.14.4 Quantificação de proteínas totais - Método Bradford ..................................................43

4.15 TRANSFORMAÇÃO DE B. EMERSONII POR AGROBACTERIUM TUMEFASCIENS ….......................................... 43

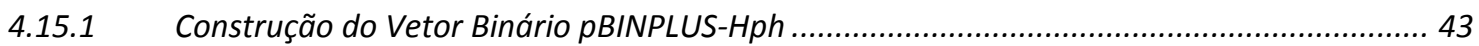

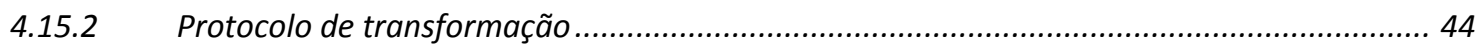

4.15.3 Extração rápida de DNA genômico de zoósporos ....................................................... 46

5 RESULTADOS E DISCUSSÃO

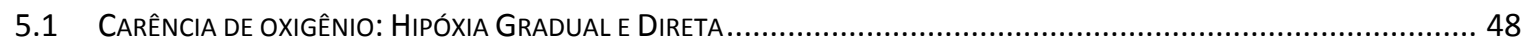

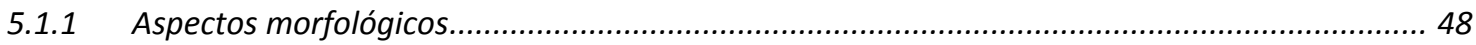

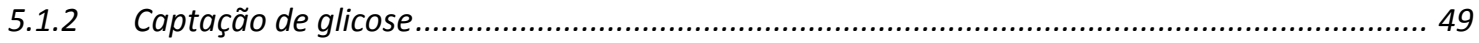

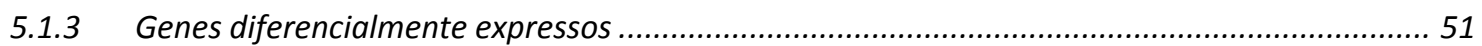

5.1.4 Agrupamento dos genes diferencialmente expressos segundo os perfis de expressão .............52

5.1.5 Determinação das categorias do Consórcio Gene Ontology (GO) mais representadas entre os

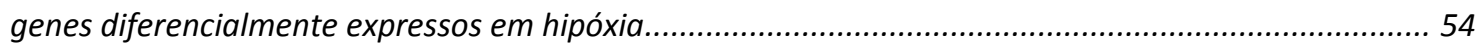

5.1.6 Análise da expressão de genes ausentes nos microarranjos por qRT-PCR ..........................56

5.1.7 Análise dos genes afetados pela concentração de oxigênio dissolvido.................................. 58 
5.1.8 Comparação da resposta transcricional de B. emersonii com a de outros fungos......

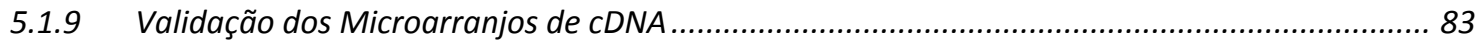

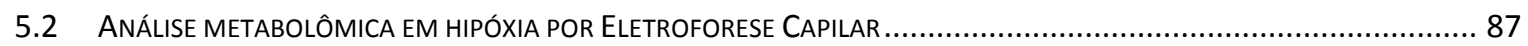

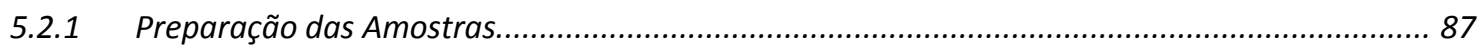

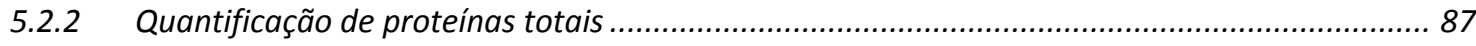

5.2.3 Análise de metabólitos catiônicos por CE-MS .............................................................. 88

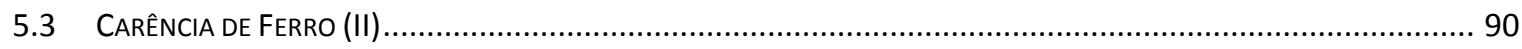

5.3.1 Análise dos genes cuja expressão é afetada pela carência de ferro (II) ................................ 90

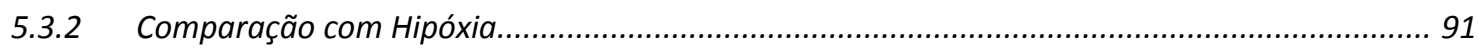

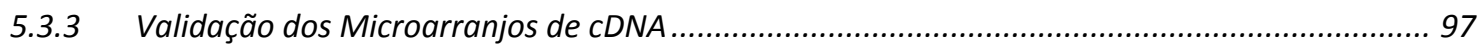

5.4 GENES REgULAdOS POR HIPÓXIA, CARÊNCIA DE FE ${ }^{2+}$, CÁDMIO E CHOQUE TÉRMICO ..........................................98

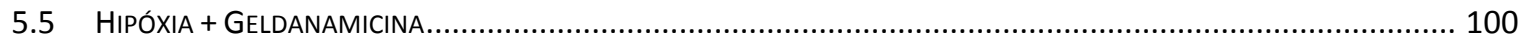

5.6 UMA PROTEÍNA DE QUITRIDIOMICETO SIMILAR AO FATOR INIBITÓRIO DE HIF-1A (FIH) ................................... 103

5.7 TRANSFORMAÇÃO DE B. EMERSONII MEDIADA POR AGROBACTERIUM TUMEFASCIENS...................................... 104

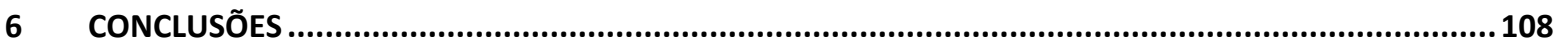

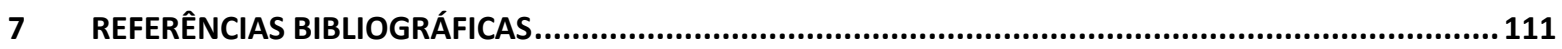

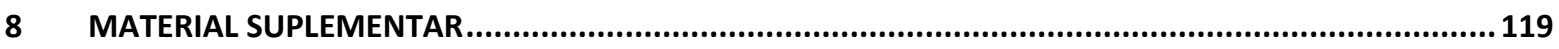

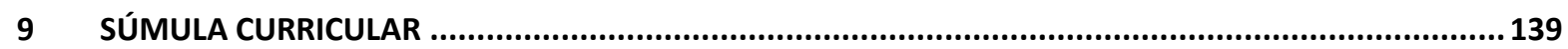




\section{LISTA DE FIGURAS}

FIGURA 1: CICLO DE VIDA DO FUNGO BLASTOCLADIELLA EMERSONII.

FIGURA 2: DISTRIBUIÇÃO DOS GENES DEPOSITADOS NAS LÂMINAS DE MICROARRANJO DE CDNA, DE ACORDO COM OS PROCESSOS BIOLÓGICOS DETERMINADOS PELO CONSÓRCIO GENE ONTOLOGY.

FIGURA 3: VISÃo ESQUEMÁtICA DO PROCESSO DE TRANSFERÊNCIA DE T-DNA POR AGROBACTERIUM TUMEFACIENS

Figura 4: EXPERIMENTO dE HIPÓXIA GRAdUAL.

FiguRA 5: EXPERIMENTO DE HIPÓXIA DIRETA

FIGURA 6: DESENHO ESQUEMÁTICO DA LÂMINA DE MICROARRANJO DE DNA.

Figura 7: Hibridização SELF-SELF de Hipóxia GRAduAl E DiRETA

FiguRA 8: PLASMÍDEOS UTILIZADOS NA CONSTRUÇão dO VETOR BINÁRIO PBINPLUS-HPH .....

FIgURA 9: ESQUEMA DO PROTOCOLO DE TRANSFORMAÇÃO DE B. EMERSONII MEDIADA POR A. TUMEFASCIENS. 46

FIGURA 10: ALTERAÇõES MORFOLÓGICAS EM CÉLULAS DE B. EMERSONII SUBMETIDAS À HIPÓXIA GRADUAL 49

FIGURA 11: EFEITO DA DISPONIBILIDADE DE OXIGÊNIO NA CAPTAÇÃO DE GLICOSE EM HIPÓXIA GRADUAL. 51

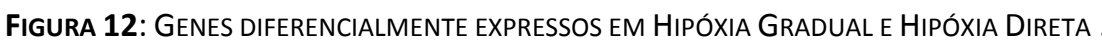

Figura 13: Agrupamento dos genes diferencialmente expressos em Hipóxia Gradual (A) e Hipóxia Direta (B)......... 53

FIGURA 14: ANÁLISE DA EXPRESSÃO POR QRT-PCR DE GENES AUSENTES NOS MICROARRANJOS DE CDNA.

FIGURA 15: GENES COM PERFIS INDUZIDOS OU REPRIMIDOS EM HIPÓXIA GRADUAL E/OU DIRETA, DISTRIBUÍDOS EM CATEGORIAS FUNCIONAIS DE ACORDO COM O GO

FiguRA 16: GENES RESPONSÁVEIS PELA BIOSSÍNTESE DE S-ADENOSIL-METIONINA (SAM).

FIGURA 17: EXPRESSÃO DOS GENES CODIFICANDO ENZIMAS DO METABOLISMO ENERGÉTICO CENTRAL DE B. EMERSONII EM HIPÓXIA GRADUAL E/OU DIRETA . 73

FIGURA 18: EXPRESSÃO GÊNICA DE ENZIMAS DA CADEIA RESPIRATÓRIA DE B. EMERSONII EM HIPÓXIA GRADUAL E/OU DIRETA...... 74

FIGURA 19: ESQUEMA DAS MODIFICAÇÕES DE LIPÍDEOS PROMOVIDAS PELAS ENZIMAS $\triangle$-9 ÁCIDO GRAXO DESATURASE E CFA SINTASE 77

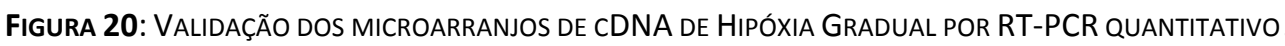
85

Figura 21: VALIDAÇÃo dOS MicroarRANJOS dE CDNA de HIPÓXIA DiRETA POR RT-PCR QUANTITATIVO. 86

Figura 22: ANÁLISE DE AMINOÁCIDOS LIVRES INTRACELULARES POR CE-MS 90

FIGURA 23: GENES INDUZIDOS OU REPRIMIDOS DURANTE CARÊNCIA DE FERRO (II), DISTRIBUÍDOS EM CATEGORIAS FUNCIONAIS... 91 
Figura 24: VALIDAÇÃo dOS EXPERIMENTOS DE MICROARRANJOS COM CÉLULAS EM CARÊNCIA DE FERRO POR RT-PCR

QUANTITATIVO

FIGURA 25: VALIDAÇÃO dOS MICROARRANJOS DO EXPERIMENTO HIPÓXIA + GELDANAMICINA

FIgURA 26: ALINHAMENTO DAS SEQUÊNCIAS DOS DOMÍNIOS JMJC DA PROTEÍNA HIPOTÉTICA DE B. DENDROBATIDIS

(BDEG_02431.1) E DAS PROTEÍNAS JMJD5 E FIH DE METAZOÁRIOS 104

FIGURA 27: APARÊNCIA TÍPICA DOS TRANSFORMANTES RESISTENTES A HIGROMICINA B 105

FIGURA 28: ANÁLISE DO DNA GENÔMICO DOS TRANSFORMANTES DE B. EMERSONII POR PCR 106 


\section{LISTA DE TABELAS}

TABELA 1: OligonUCLEOTídEOS UTILIZADOS NOS EXPERIMENTOS DE QRT-PCR PARA VALIDAÇÃo DOS MICROARRANJOS E ANÁLISE DA EXPRESSÃO GÊNICA DE GENES AUSENTES NAS LÂMINAS.

TABela 2: CATEgorias do Gene Ontology (GO) MAIS REPRESENTAdAS ENTRE OS GENES COM PERFIS INDUZIDOS E REPRIMIDOS EM HIPÓXIA GRADUAL E DIRETA 55

TABELA 3: LISTA DE GENES AFETADOS POR HIPÓXIA GRADUAL E/OU DIRETA OBTIDOS PELA TÉCNICA DE MICROARRANJO DE CDNA 59

TABELA 4: QUANTIFICAÇÃo de PROTEÍNAS TOTAIS NOS EXTRATOS METABÓLICOS DE B. EMERSONII ..... 88

TABELA 5: LISTA DE GENES AFETAdOS POR CARÊNCIA DE FERRO (II) OBTIDOS PELA TÉCNICA DE MICROARRANJO de CDNA E A COMPARAÇÃO COM OS MICROARRANJOS DE HIPÓXIA GRADUAL E/OU DIRETA. 93

TABela 6: Genes RegulAdOS POR HIPÓXIA, CARÊNCIA DE FE ${ }^{2+}$, CÁDMIO E CHOQUE TÉRMICO 99

TABela 7: GENES DE HIPÓXIA AFETAdOS PELO TRATAMENTO COM GELDANAMICINA 101

\section{LISTA DE TABELAS SUPLEMENTARES}

TABELA S 1: LISTA COMPLETA DOS GENES DIFERENCIALMENTE EXPRESSOS EM HIPÓXIA GRADUAL E DIRETA

TABELA S 2: LISTA COMPLETA DOS GENES DIFERENCIALMENTE EXPRESSOS POR CARÊNCIA DE FERRO (II) E COMPARAÇÃO COM OS MICROARRANJOS DE HIPÓXIA GRADUAL E DIRETA

TABELA S 3: LISTA COMPLETA DOS GENES DIFERENCIALMENTE EXPRESSOS NO EXPERIMENTO DE HIPÓXIA + GELDANAMICINA...... 136 


\section{ABREVIATURAS E SIGLAS}

ATP - Adenosina trifosfato

ATPase - Adenosina trifosfatase

BSA - Albumina acetilada de soro bovino

$\mathrm{Ca}^{2+}$ - Cálcio

CaM - Calmodulina

cAMP - Adenosina monofosfato cíclico

cDNA - DNA complementar

cGMP - Guanosina monofosfato cíclico

CTAB - brometo de cetil-trimetil-amônio

DEPC - Dietilpirocarbonato

DM4 - Meio definido

DMSO - Dimetilsulfóxido

DNB - ácido dinitrobenzóico

DO - Densidade óptica

DPY - 2,2'-dipyridyl

EDTA - Ácido etilenodiaminotetracético

EST - Expressed sequence tag

$\mathrm{g}$ - Unidades de gravidade

GO - Gene Ontology

GTP - Guanosina trifosfato

$\mathrm{h}$ - Hora

HIF-1 - Hypoxia-inducible Factor 1

HSP - Heat Shock Protein

ID - Identidade

$\mathrm{kDa}$ - Quilodaltons

M - Molar

MOPS - Ácido 3-[N-morfolino] propanosulfônico

$\mu \mathrm{g}$ - Micrograma

$\mu 1$ - Microlitro

$\mu \mathrm{m}$ - Micrômetro

nm - Nanômetro 
$\mathrm{nM}$ - Nanomolar

$\mathrm{O}_{2}-$ Oxigênio molecular

PIPES - piperazina-N,N'-bis-[ácido etanossulfônico]

$\mathrm{pb}$ - Pares de base

PMSF - Fluoreto de fenilmetilsulfona

PYG - Peptona - extrato de levedura - glicose

rpm - Rotações por minuto

RT-PCR - Reação de polimerização em cadeia em tempo real

SDS - Dodecil sulfato de sódio

SREBP - Sterol-response element binding protein

TBE - Tampão Tris-Borato EDTA

TBS - Tampão tris-borato SDS

Ciclo TCA - Ciclo do ácido tricarboxílico

Tris - Tris-(hidroxometil)-aminometano 


\section{INTRODUÇÃO}

Aproximadamente 1,7 milhão de espécies de organismos pertencentes ao ecossistema terrestre já foram descritas e catalogadas. Essa enorme variabilidade se deve a milhões de anos de evolução e revelam adaptações das espécies a distintas condições ambientais e nutricionais, o que proporciona marcantes diferenças entre esses organismos no que diz respeito a aspectos como morfologia, organização celular, fisiologia, metabolismo, entre outros.

Mesmo com inúmeras diferenças, organismos evolutivamente distantes também podem guardar características semelhantes, que foram preservadas por apresentarem vantagens evolutivas e conferirem adaptação às condições de vida vigentes. Um bom exemplo, do ponto de vista bioquímico, é o metabolismo energético de produção de energia em eucariotos. Glicose, o monossacarídeo mais abundante na natureza e fonte preferencial de carbono e energia para grande parte dos organismos (Johnston, 1999; Vaulont et al., 2000), apresenta um papel central na produção de energia através da via glicolítica (glicólise), vias alternativas do metabolismo do piruvato, ciclo dos ácidos tricarboxílicos (TCA ou ciclo de Krebs) e cadeia respiratória (transporte de elétrons e fosforilação oxidativa). No entanto, mesmo que relativamente conservada ao longo da evolução, essa rede metabólica pode ser regulada de maneira distinta entre as espécies, devido a diferentes pressões seletivas (Pfeiffer et al., 2001). Deste modo, a produção de energia na forma de ATP pode ocorrer tanto de forma aeróbia (respiração) quanto anaeróbia (fermentação), dependendo do organismo, do tecido ou do estado metabólico da célula. A disponibilidade de oxigênio é, portanto um ponto chave no metabolismo e, em última instância, na sobrevivência da maioria dos organismos eucarióticos.

$\mathrm{Na}$ natureza, situações de privação de oxigênio podem ocorrer com uma alta freqüência, por isso, os organismos desenvolveram um complexo conjunto de respostas 
adaptativas celulares e moleculares, ativado pela própria diminuição da disponibilidade de oxigênio. Estas respostas são adaptativas, pois podem levar a alterações fisiológicas e metabólicas permitindo às células lidarem com o estresse associado à limitação de oxigênio e, em última instância, reforçam a sobrevivência celular. Especialmente nos habitats aquáticos, a hipóxia pode ser uma importante força motriz evolutiva resultando em estratégias fisiológicas de sobrevivência à carência de oxigênio.

Cabe enfatizar aqui que o termo "hipóxia" indica baixa tensão de oxigênio dissolvido, mas a concentração de oxigênio em que se caracteriza hipóxia é controversa na literatura, pois se baseia na mínima concentração tolerável para determinado organismo e, por isso, é variável. Em geral a concentração adotada para mamíferos e leveduras fica em torno de 5 a $10 \%$ de saturação de $\mathrm{O}_{2}$ do $\operatorname{ar}\left(\% \mathrm{satO}_{2}\right)$.

Em 1861, Louis Pasteur (Pasteur, 1861) mostrou que o oxigênio inibe o processo fermentativo e que o consumo de glicose é inversamente proporcional à disponibilidade de oxigênio, mostrando que a glicólise é positivamente regulada por hipóxia, o chamado “Efeito Pasteur". Tal efeito pode ser observado em diversos organismos, dentre os quais o eucarioto unicelular Saccharomyces cerevisiae. Análise transcricional global nessa levedura mostrou que quase todos os genes dos complexos respiratórios e de enzimas do ciclo de Krebs eram reprimidos em condições de crescimento anaeróbico, enquanto genes envolvidos na glicólise, síntese de glicerol e genes para as isoformas citoplasmáticas da álcooldesidrogenase eram induzidos (Kwast et al., 2002). Medidas de fluxos metabólicos mostraram que a anóxia aumentava o fluxo glicolítico até a produção de etanol e glicerol (Nissen et al., 1997), indicando que o re-direcionamento metabólico de aerobiose para anaerobiose (fermentação) é fundamentalmente controlado em nível transcricional.

O mesmo pode ser observado em células de tecido muscular esquelético de mamíferos em grandes altitudes ou durante o exercício (Vogt et al., 2001), e em células de 
tumores sólidos (Helmlinger et al., 1997). Devido ao fato de serem submetidas a condições de hipóxia, elas não podem obter energia total da glicose pelo metabolismo oxidativo e, por isso, o metabolismo anaeróbico gera parte de seu ATP, reduzindo piruvato a lactato. Este processo se opera a uma taxa mais alta, mas produzindo menos ATP a partir da mesma quantidade de substrato (glicose).

Num estudo recente com o fungo filamentoso multicelular e aeróbico obrigatório, Trichoderma reesei, foi demonstrado que hipóxia e anóxia transiente causam uma diminuição na produção de ATP, como resultado de uma drástica repressão da transcrição da maioria dos genes codificando enzimas da via glicolítica e do ciclo de Krebs (Bonaccorsi et al., 2006). Este tipo de resposta parece contradizer o tradicional "Efeito Pasteur" e deve estar mais relacionada a mecanismos de tolerância em longo prazo, como o observado em tartarugas tolerantes a anóxia (Stecyk et al., 2004). Organismos tolerantes a hipóxia raramente ativam o metabolismo anaeróbico para suprir seu déficit energético; ao invés disso favorecem uma redução do "turnover" energético, entrando num estado chamado de suspensão de animação (Hochachka and Lutz, 2001).

Dificilmente encontrar-se-á um eucarioto tão estudado quanto Saccharomyces cerevisiae. Durante décadas essa levedura tem sido usada como modelo de estudo de diversas funções celulares básicas e processos bioquímicos em sistemas eucarióticos. Entretanto, no que diz respeito a estudos de resposta a hipóxia, S. cerevisiae torna-se limitada por ser um organismo anaeróbico facultativo, e isto deve ser considerado quando se compara essa levedura com outros modelos celulares. Além disso, S. cerevisiae é dotada de um metabolismo com características peculiares e versáteis, não encontradas comumente em outros eucariotos, incluindo a maioria das leveduras. Um exemplo é a produção de etanol através do metabolismo anaeróbico, mesmo na presença de oxigênio (Breunig et al., 2000). 
Esta tese de doutorado aborda os efeitos transcricionais decorrentes da diminuição da concentração de oxigênio dissolvido em culturas do fungo aquático Blastocladiella emersonii (seção 2.3), que está localizado na base da árvore filogenética dos fungos. $B$. emersonii apresenta um metabolismo estritamente aeróbico e pode ser um interessante modelo de estudo de resposta ao estresse de hipóxia, por estar potencialmente adaptado a ambientes com pouca aeração, uma vez que possui um comportamento saprofítico aquático (Lovett, 1975). Neste trabalho, analisamos as respostas transcricionais e metabólicas de $B$. emersonii a decrescentes concentrações de oxigênio dissolvido, utilizando as técnicas de microarranjos de DNA e eletroforese capilar, respectivamente.

Como será abordado na seção 2.2, HIF-1 (hypoxia-inducible factor 1) é o principal regulador da homeostase de oxigênio em metazoários. Sabe-se que quelantes de ferro (II) como 2,2'-dipyridyl, são conhecidos agentes mimetizadores de hipóxia através da estabilização de HIF-1 $\alpha$ (Semenza, 2007) e que inibidores da proteína de choque térmico HSP90 como a geldanamicina, induzem a degradação de HIF-1 $\alpha$ de maneira independente de oxigênio (Liu and Semenza, 2007). Por isso, procuramos encontrar evidências de um possível sistema sensor de oxigênio em B. emersonii, similar ao HIF-1, pela comparação entre as respostas transcricionais globais de células submetidas à hipóxia, carência de ferro (II) e tratamento com geldanamicina seguido de hipóxia. Este estudo comparativo, realizado nesta tese, embora não tenha resultado na elucidação do mecanismo regulatório da resposta à concentração de oxigênio em $B$. emersonii, forneceu evidências da existência de um mecanismo similar ao HIF-1. Pelo menos no que diz respeito ao padrão da resposta transcricional à hipóxia e aos estímulos que afetam a atividade deste regulador, como carência de ferro (II) ou inibição da HSP90.

A transformação de Blastocladiella emersonii foi sempre um dos objetivos do laboratório. Diversos estudos atualmente conduzidos neste fungo poderiam ser 
consideravelmente enriquecidos pela utilização de técnicas de manipulação genética, entretanto, até o momento $B$. emersonii revelou-se inapropriada em diversos experimentos de transformação, quando testada por diferentes metodologias, como eletroporação, uso de protoplasto e até biobalística. Como objetivo adicional, resolvemos desenvolver um protocolo de transformação de $B$. emersonii mediado pela bactéria gram-negativa Agrobacterium tumefaciens (seção 2.5). Este tipo de transformação, comumente utilizado em plantas, mostrou ser eficiente para diversos fungos, leveduras e até células humanas (Bundock et al., 1995; Chen et al., 2000; de Groot et al., 1998; Kunik et al., 2001; Zwiers and De Waard, 2001). Demonstramos que Agrobacterium tumefasciens pode transferir seu T-DNA, contendo um cassete de resistência a higromicina B, para o DNA genômico de células de Blastocladiella emersonii. Este trabalho representa o primeiro protocolo de transformação de Blastocladiomicetos existente até o momento. 


\section{REVISÃO DA LITERATURA}

\subsection{Aspectos evolutivos nas vias de produção de ATP}

Após o surgimento do oxigênio na atmosfera, o metabolismo aeróbico nos eucariotos se desenvolveu com o surgimento das mitocôndrias. Este tipo de metabolismo apresenta uma marcante vantagem sobre o metabolismo fermentativo que é o alto rendimento na produção de ATP a partir de uma mesma quantidade de glicose. No entanto, produção aeróbica de ATP apresenta uma menor velocidade quando comparada com a anaeróbica. Isto se deve ao fato de que no catabolismo de qualquer substrato, parte de sua energia livre é conservada nas moléculas de ATP, enquanto outra parte é necessariamente consumida para poder alimentar as reações envolvidas no processo. Portanto, reações que consomem menos da energia contida no substrato, como no caso da respiração, ocorrem em menor velocidade, mas com rendimento maior. Por outro lado, a maior utilização da energia contida no substrato resulta em um processo mais rápido, porém com menor rendimento.

De fato, o metabolismo aeróbico gera 38 mols de ATP por mol de glicose consumida, ao passo que o metabolismo fermentativo apresenta um rendimento de apenas 2 mols de ATP por mol de glicose consumida. Foi demonstrado recentemente por Pfeiffer e colaboradores (Pfeiffer et al., 2001) que o metabolismo fermentativo apresenta uma vantagem sobre o respiratório em casos em que há disputa por fontes de carbono ou limitação de oxigênio. Nessas situações, levam vantagem os organismos capazes de consumir mais rapidamente o substrato disponível. Por outro lado, consumir rapidamente os nutrientes, com baixo rendimento, limita o potencial crescimento das populações. Segundo os autores, o modelo pelo qual os organismos conseguiram se aproveitar do metabolismo aeróbico foi o de cooperação entre os competidores, sejam eles da mesma espécie ou de espécies distintas. Segundo os modelos simulatórios utilizados, em ambientes com baixa taxa de difusão celular, o metabolismo aeróbico tende a prevalecer, pois as células tendem a 
estar rodeadas por membros de seu próprio estilo metabólico. Conforme a taxa de difusão celular aumenta, os organismos passam a disputar os mesmos substratos de maneira global e, assim, os fermentadores prevalecem. A partir destas evidências, levanta-se a hipótese de que o alto rendimento da produção de ATP proporcionado pelo metabolismo aeróbico pode ter ajudado a direcionar a evolução de organismos unicelulares para formas multicelulares indiferenciadas. O fungo dimórfico Mucor racemosus encaixa-se perfeitamente neste modelo, uma vez que utiliza o metabolismo fermentativo quando na forma unicelular (levedura), mas respira quando na forma multicelular (micélio) (Inderlied and Sypherd, 1978).

\subsection{Respostas a carência de oxigênio}

A vida aeróbica na Terra iniciou-se há dois bilhões de anos e sua evolução resultou em organismos extremamente dependentes de oxigênio. Tal dependência faz com que a exposição de tais organismos a tensões de oxigênio fora de certo limite fisiológico resulte em estresse celular e consequentemente toxicidade. Em seres humanos, particularmente, a hipóxia está relacionada a diversas doenças, principalmente àquelas relacionadas com problemas vasculares, incluindo todas as formas de anemias e isquemias. O principal regulador de homeostase de oxigênio em metazoários é o HIF-1 (Hypoxia-Inducible Factor 1), um complexo transcricional que, sob condições de hipóxia regula genes via elementos responsivos a hipóxia (HRE) presentes nas regiões promotoras desses alvos. HIF-1 é um heterodímero composto por duas subunidades, $\alpha$ e $\beta$, ambas pertencentes à família de proteínas PAS, com domínios bHLH (basic helix-loop-helix). HIF-1 $\beta$ mantém seus níveis constantes sob hipóxia, sendo, portanto totalmente insensível à $\mathrm{O}_{2}$. Diferentemente, os níveis de HIF-1 $\alpha$ são altamente regulados pela concentração de oxigênio dissolvido. Em condições de hipóxia, a degradação de HIF-1 $\alpha$ é inibida e essa proteína se acumula e forma um dímero 
com HIF-1 $\beta$, ligando-se aos elementos HRE em genes-alvo e recrutando proteínas coativadoras que levam ao aumento da transcrição desses genes (Semenza, 2007). Tem sido demonstrado um papel fundamental do fator HIF-1 $\alpha$ na resposta de diferentes tecidos submetidos à falta de oxigênio, inclusive em tumores sólidos malignos. Estes tumores, por crescerem rapidamente, geralmente são mal vascularizados e sofrem hipóxia em seu interior. HIF-1 $\alpha$ acaba, então, sendo acumulado nessas células, ativando diversos processos celulares de adaptação incluindo angiogênese, aumento da distribuição de oxigênio (eritropoetina) e também o aumento do metabolismo anaeróbixo, através da indução da expressão de diversas enzimas glicolíticas e da lactato desidrogenase (Marin-Hernandez et al., 2009).

Em condições de normóxia, HIF-1 $\alpha$ é continuamente sintetizado, e degradado pela ligação da proteína VHL (von Hippel-Lindau tumor-suppressor protein), a qual recruta HIF$1 \alpha$ para ubiquitinação e degradação pelo proteassomo. A ligação da proteína VHL a HIF-1 $\alpha$ é dependente da hidroxilação de HIF-1 $\alpha$ realizada pela proteína prolyl hydroxylase domain protein 2 (PHD2), uma dioxigenase que utiliza $\mathrm{O}_{2}$ e $\alpha$-cetoglutarato como substratos, gerando $\mathrm{CO}_{2}$ e succinato. Esta enzima é responsável pela hidroxilação de resíduos de prolina $\left(\right.$ Pro $^{402}$ e Pro $\left.{ }^{564}\right)$ presentes no domínio de degradação oxigênio-dependente (ODDD) de HIF$1 \alpha$, também conhecidos por PHDs (Prolyl Hydroxylase domain-containing proteins) ou EGLN (egg-layin-defective nine) (Semenza, 2007). Desta maneira, em condições de baixo oxigênio, a hidroxilação dos resíduos $\operatorname{Pro}^{402}$ e $\operatorname{Pro}^{564}$ de HIF-1 $\alpha$ é deficiente, impedindo a ligação de VHL e, por conseqüência, a degradação pelo proteassomo.

O fator inibitório de HIF-1 (FIH-1) é outra dioxigenase dependente de $\alpha$ cetoglutarato, que hidroxila um resíduo de asparagina $\left(\mathrm{Asp}^{803}\right)$ de HIF-1 $\alpha$, levando à sua inativação devido ao bloqueio de sua interação com seus coativadores CBP e p300, impedindo assim, a indução de genes de hipóxia (Semenza, 2007; Taylor, 2008). Tanto PHD2 quanto FIH contêm $\mathrm{Fe}^{2+}$ em seus centros catalíticos (Semenza, 2007). Por esta razão, 
quelantes deste íon são conhecidos por mimetizarem os efeitos de hipóxia através da estabilização de HIF-1 $\alpha$.

HIF-1 $\alpha$ também pode ser regulado de maneira independente de oxigênio, PHD e VHL, através da proteína RACK1 (receptor of activated protein $C$ kinase). RACK1 compete o domínio PAS-A de HIF-1 $\alpha$ com a chaperona molecular HSP90 (heat shock protein 90). Quando ligada, RACK1 recruta HIF-1 $\alpha$ à ubiquitinação e degradação pelo proteassomo. No entanto, HSP90 compete com RACK1 protegendo HIF-1 $\alpha$ e mantendo seus níveis basais na célula, independentemente da concentração de oxigênio. Inibidores da HSP90 como o antibiótico geldanamicina são conhecidos por induzir a degradação de HIF-1 $\alpha$ independentemente de oxigênio (Liu and Semenza, 2007).

Leveduras, como Saccharomyces cerevisiae, são anaeróbios facultativos capazes de crescer com ou sem uma mitocôndria ativa (Ferguson and von Borstel, 1992) e, apesar disso, têm sido estudadas como modelo de resposta à privação de oxigênio. Apesar de suas limitações quanto a comparações com mamíferos, os estudos conduzidos com essa levedura ilustram o quão poderosas são as pressões seletivas inerentes a um metabolismo anaeróbico facultativo. A necessidade de sobreviver e crescer em diferentes tensões de oxigênio promoveu o surgimento de um sistema coordenado e simultâneo que regula a expressão de uma série de genes, muitas vezes sem qualquer ligação entre eles (Zitomer et al., 1997). O sistema mais estudado de resposta à hipóxia em $S$. cerevisae é o sistema Rox1-Hap1 e Hap2/3/4/5 (Kwast et al., 1998; Lai et al., 2006; Zitomer et al., 1997). De acordo com este sistema, níveis normais de heme são suficientes para ativar fatores de transcrição como Hap1 e Hap2/3/4/5, que controlam a expressão de genes aeróbicos. Quando os níveis de oxigênio caem, a biossíntese de heme também declina, resultando na desativação destes fatores e, consequentemente, na regulação negativa dos genes por eles regulados. Um dos genes-alvo destes fatores é Roxl, que codifica um repressor de genes anaeróbicos (Kwast et 
al., 2002; Laabs et al., 2003) e que também regula a expressão de UPC2 (Kwast et al., 2002), um ativador de genes anaeróbicos.

Além deste sistema, existe outro mecanismo que regula a resposta transcricional de S. cerevisiae a condições anaeróbicas. Certos genes induzidos em hipóxia como OLE1, que codifica uma desaturase essencial para síntese de ácidos graxos, chamada 4-9-fatty acid desaturase, possuem em suas sequências promotoras um elemento chamado LORE (low oxygen responsive element), onde se ligam um complexo de fatores responsivos à hipóxia que ainda não são bem conhecidos (Webster, 2003). A transcrição de $O L E 1$ em leveduras é reprimida por ácidos graxos insaturados e tem sua indução dependente da proteína Mga2p (Nakagawa et al., 2003). Mga2p fica normalmente ligada à membrana do retículo endoplasmático e é ativada por uma clivagem dependente de ubiquitinação. Uma vez liberada, Mga2p age protegendo os mRNAs de genes-alvo como OLE1 (Kandasamy et al., 2004). Embora as sequências LORE não se assemelhem com as sequências HRE (hypoxiaresponse element) reconhecidas por HIF-1 em mamíferos, e apesar de não haver sido comprovado o envolvimento de prolil-hidroxilases no sistema de leveduras, alguns autores têm sugerido que ambos os sistemas possuem mecanismos semelhantes. Esta conclusão se deve principalmente às respostas observadas com metais de transição e quelantes de ferro nos dois sistemas (Jiang et al., 2001; Vasconcelles et al., 2001; Webster, 2003).

É interessante notar que nem sempre o estresse de hipóxia é prejudicial. Em certos organismos patogênicos observou-se que quando estes organismos enfrentam processos inflamatórios, tromboses e necroses em seus hospedeiros, o estresse de hipóxia atua como um sinal regulador para a indução de processos de virulência essenciais para a sobrevivência do patógeno (Chun et al., 2007). Em bactérias patogênicas classificadas como aeróbias estritas, como Neisseria meningiditis ou Bordetella pertussis, a mutação de um fator 
homólogo ao regulador responsivo a hipóxia Fnr, de Escherichia coli, levou à atenuação de virulência em animais de experimentação (Bartolini et al., 2006; Wood et al., 1998).

Dentre os fungos, alguns patógenos como Candida albicans são capazes de realizar fermentação anaeróbica em meios ricos. No entanto, nestes organismos o oxigênio molecular é necessário para síntese de moléculas essenciais como ergosterol, NAD e heme, difíceis de obter mesmo em hospedeiros. Deste modo, a hipóxia em fungos, tanto patogênicos quanto não patogênicos, deve ser, em princípio, um desafio mais significativo do que para bactérias, mesmo naquelas aeróbicas estritas.

O ascomiceto não-patogênico Schizosaccharomyces pombe possui um sistema homólogo ao SREBP (“sterol-response element binding protein") de mamíferos e foi mostrado que este sistema tem um papel regulador da adaptação à hipóxia neste fungo (Hughes et al., 2005; Todd et al., 2006). Este fator também foi descrito no basidiomiceto patógeno Cryptococcus neoformans e parece estar relacionado com sua patogenicidade, além de funcionar como sistema sensor de oxigênio (Chang et al., 2007).

Neste sistema, em mamíferos, SREBP é seqüestrado para o retículo endoplasmático (RE), quando na presença de esteróis como o colesterol. Na ausência deste sinal, entretanto, SREBP sofre clivagens específicas que levam à ativação de genes que controlam o metabolismo de lipídeos. Na presença de esteróis, Scap (“SREBP cleavage-activating protein") se liga a SREBP no retículo endoplasmático e assume uma conformação que permite a ligação da proteína Insig (“insulin-induced gene”). Isto mantém o complexo SREBP-Scap no retículo, pois impede a interação de SCAP com COPII vesicle-formation proteins Sar1, Sec23 e Sec24. Na ausência de esteróis, a ligação a Insig é rompida e o complexo SREBP-Scap é englobado por vesículas de transporte cobertas por COPII. O complexo é então transportado ao complexo de Golgi, onde sofre duas clivagens proteolíticas sequenciais mediadas pelas proteases Site 1 (S1P) e Site 2 (S2P), liberando o 
domínio N-terminal de SREBP que será transportado ao núcleo (Espenshade, 2006). A ação deste regulador sobre sequências SRE ("sterol regulatory element") presentes nos promotores de genes-alvo, leva ao aumento da síntese e captura de colesterol. Em S. pombe, a via homóloga a SREBP controla a expressão de genes envolvidos na síntese de ergosterol e algumas evidências sugerem que a hipóxia sinaliza esta via pela redução dos níveis de esteróis, indicando que esta SREBP pode funcionar como um sistema sensor de oxigênio (Hughes et al., 2005; Todd et al., 2006).

\subsection{O modelo de estudo: Blastocladiella emersonii}

O fungo aquático não-filamentoso Blastocladiella emersonii pertence à classe dos Blastocladiomicetos, ordem Blastocladiales (Hibbett et al., 2007) e foi isolado pela primeira vez por Cantino, em 1951. Em seu ciclo de vida, B. emersonii sofre drásticas mudanças morfológicas e bioquímicas, principalmente durante dois estágios de diferenciação celular: a germinação e a esporulação. Ao longo desses estágios, é possível identificar morfologicamente quatro formas celulares que se alternam de maneira cíclica: zoósporo, gérmen, célula vegetativa e zoosporângio.

O zoósporo, uma célula móvel uninucleada, dotada de um flagelo e sem parede celular, germina rapidamente quando exposto a um meio nutriente ou solução inorgânica contendo certos cátions monovalentes $\left(\mathrm{K}^{+}\right.$e $\mathrm{Na}^{2+}$ ), AMP cíclico (cAMP), GMP cíclico (cGMP) ou inibidores da fosfodiesterase de cAMP (Gottschalk and Sonneborn, 1982; Maia et al., 1979; Soll and Sonneborn, 1972). Em meio nutriente DM4, a 27 C, o zoósporo retrai o seu flagelo e forma uma fina parede celular de quitina, nos primeiros 15 minutos, transformando-se em uma célula denominada esferócito. Aproximadamente 45 minutos após a indução da germinação, um tubo germinal (rizóide primário) se desenvolve dando origem ao gérmen que é capaz de crescer. Este tubo germinal dará origem por ramificação a um 
sistema de rizóides através dos quais os nutrientes são absorvidos (Lovett, 1975). Aos 120 minutos ocorre a primeira divisão nuclear, marcando o fim da germinação e o início do crescimento vegetativo exponencial, caracterizado por intensa cariocinese não acompanhada citocinese, produzindo um cenócito. Essa fase de desenvolvimento pode durar mais de 15 horas a $20^{\circ} \mathrm{C}$ e quando o meio se torna carente em nutrientes, as células entram em processo de esporulação. Durante esse estágio, em condições normais de cultivo, cada cenócito vegetativo adquire em poucas horas uma parede delgada e não pigmentada, formando assim o zoosporângio. A esporulação pode ser induzida em condições experimentais por meio da lavagem e incubação das células vegetativas em uma solução tamponada contendo $1 \mathrm{mM}$ $\mathrm{Ca}^{2+}$. Após 60 minutos da indução da esporulação, observa-se o aparecimento de um septo basal que separa os rizóides do corpo da célula. Cerca de 60 minutos após a observação do septo verifica-se a formação de uma papila de descarga no ápice do zoosporângio através da qual serão liberados os zoosporos no final do processo. Em uma fase mais tardia, observa-se a clivagem do citoplasma em torno de cada núcleo culminando com a formação e liberação dos zoósporos para o meio, completando assim o ciclo de vida do fungo (Figura 1). Vale lembrar que os experimentos deste trabalho foram realizados somente com células em crescimento vegetativo. 


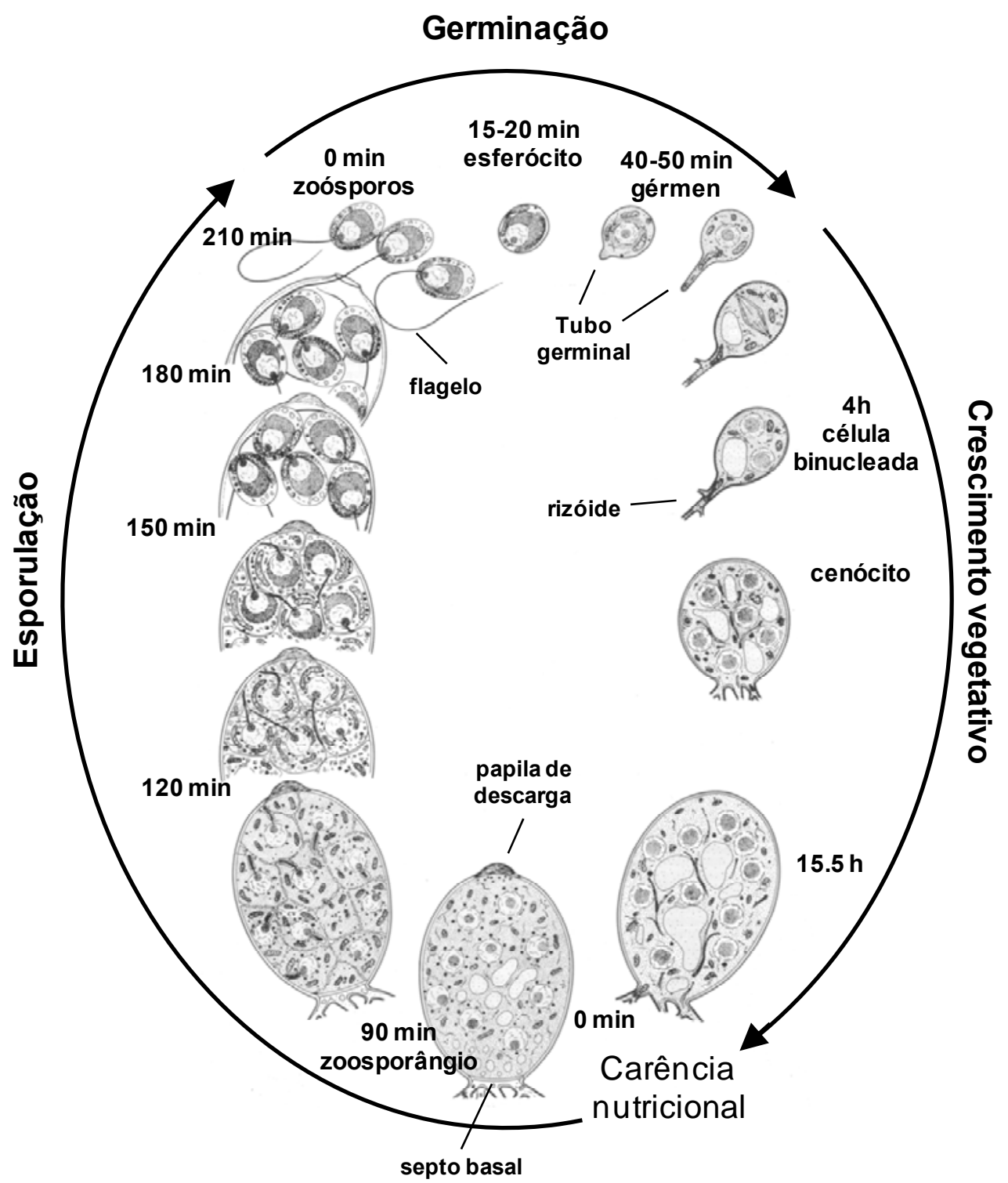

Figura 1: Ciclo de vida do fungo Blastocladiella emersonii (Adaptado de Lovett, 1975)

Blastocladiella emersonii é um interessante modelo de estudos de expressão gênica e diferenciação celular entre os fungos primitivos, pois está localizada na base da árvore filogenética dos fungos e, além disso, por apresentar diversas mudanças bioquímicas e morfológicas ao longo de seu ciclo de vida.

Com o objetivo de contribuir para o entendimento da complexidade do genoma de Blastocladiella emersonii, recentemente foi realizado um sequenciamento em larga escala de clones de cDNA (ESTs ou "expressed sequence tags"), disponível no endereço 
http://blasto.iq.usp.br/, provenientes de bibliotecas de expressão construidas a partir de mRNAs de células isoladas de diversos estágios do ciclo de vida do fungo e sob condições de estresse por exposição a cádmio e choque térmico (Georg and Gomes, 2007; Ribichich et al., 2005). Foram sequenciados parcialmente, a partir das extremidades 5', aproximadamente 20.000 clones de cDNA provenientes de 10 diferentes bibliotecas. Este seqüenciamento produziu 16.984 ESTs de alta qualidade que foram reunidos em 4.873 transcritos putativos, dos quais $48 \%$ não apresentaram qualquer similaridade com sequências disponíveis em bases de dados públicas. Foram construídas lâminas de microarranjos de cDNA (Salem-Izacc et al., 2009; Georg and Gomes, 2007) que contêm 3.773 ESTs distintas, depositadas pelo menos em duplicata, provenientes das bibliotecas de estresse por cádmio e choque térmico (804 ESTs) e de fases do ciclo de vida (2.969 ESTs). A classificação destes ESTs, conforme o consórcio Gene Ontology, é mostrada na Figura 2, em termos de porcentagem de genes anotados em cada processo biológico. 


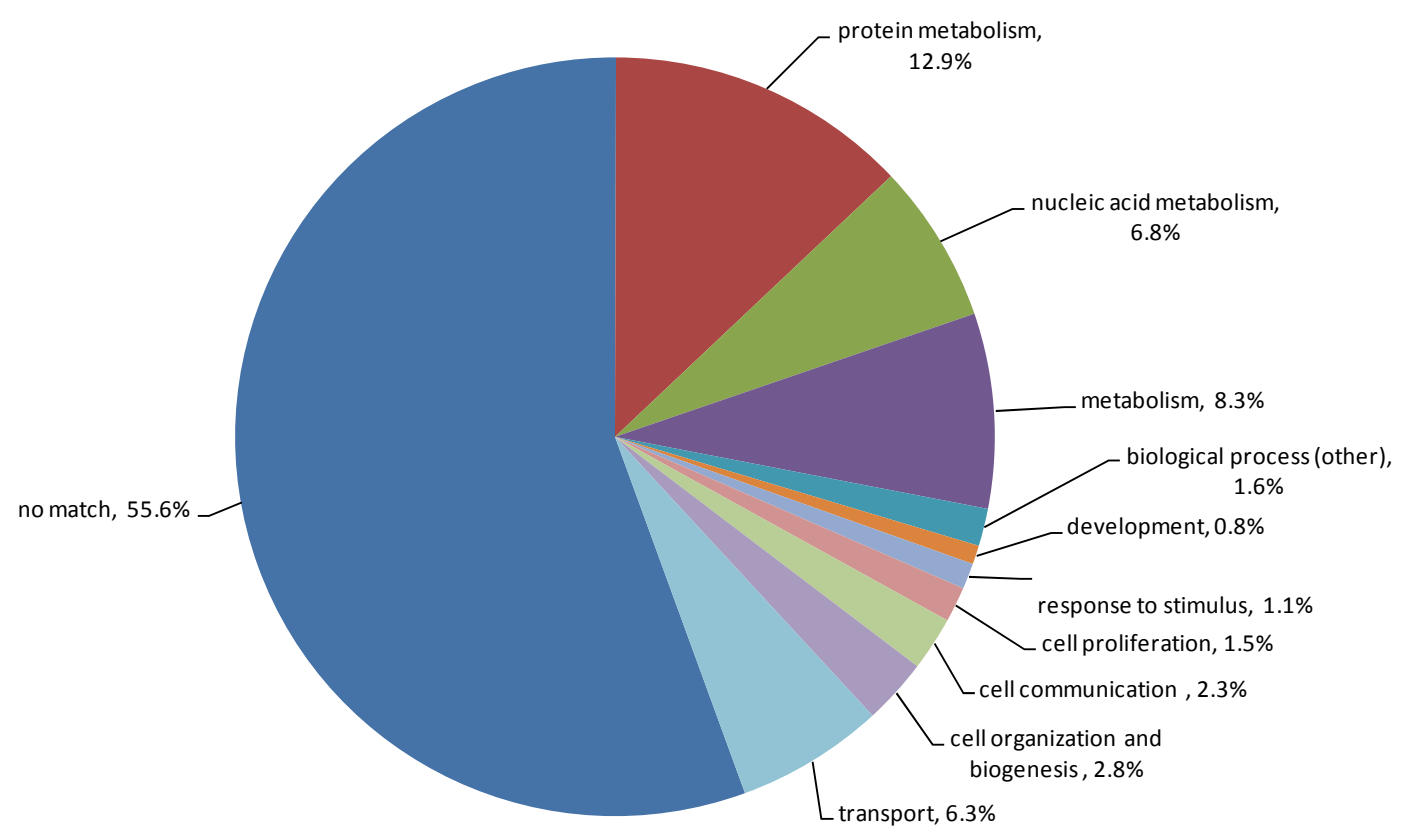

Figura 2: Distribuição dos genes depositados nas lâminas de microarranjo de cDNA, de acordo com os processos biológicos determinados pelo consórcio Gene Ontology.

Este projeto de seqüenciamento revelou sequências expressas em $B$. emersonii previamente consideradas específicas de animais ou plantas, além de outras altamente divergentes quando comparadas a de outros fungos (Ribichich et al., 2005; Ribichich et al., 2006). Além disso, proporcionou um melhor entendimento das respostas transcricionais de B. emersonii à diferenciação celular (Salem-Izacc et al., 2009; Vieira and Gomes, 2009) e estresses ambientais (Georg and Gomes, 2007; Georg et al., 2009).

Outro fruto deste projeto de seqüenciamento é um trabalho recente em que foi sugerido que o cGMP acumulado durante a esporulação de $B$. emersonii é produzido por uma guanilato ciclase que responde a óxido nítrico (NO) (Vieira et al., 2009). Este tipo de transdução de sinal nunca foi encontrado em fungos superiores, no entanto parece que fungos primitivos como os Blastocladiomicetos, que são dotados de células móveis, 
provavelmente retiveram estes genes, uma vez que a sinalização por cGMP está envolvida com motilidade celular.

Por estas características tão peculiares, B. emersonii tem se mostrado um interessante e promissor modelo para o estudo de diferenciação celular, evolução, sinalização celular e expressão gênica diferencial em resposta a estresses. No caso deste trabalho, há fortes evidências de que este fungo pode ser também um interessante modelo de estudo de resposta ao estresse de hipóxia em eucariotos, já que deve estar potencialmente adaptado a ambientes com pouca aeração, devido ao seu comportamento saprofítico aquático (Lovett, 1975).

\subsection{Estudos metabolômicos utilizando a técnica de Eletroforese Capilar}

A metabolômica, por analogia aos termos genômica, transcriptômica e proteômica, pode ser definida como uma análise qualitativa e quantitativa de todos os compostos de baixo peso molecular (metabólitos) presentes numa célula. A abordagem metabolômica tem se tornado um campo emergente da bioquímica analítica e o desenvolvimento deste método para uma análise quantitativa compreensiva de ácidos orgânicos, carboidratos e nucleotídeos é de grande valia nesta nova era de genômica funcional. Proteínas e metabólitos são os principais efetores de fenótipo por serem as entidades funcionais nas células. Sendo assim, a análise de mudanças metabólicas não só fornece informações sobre o estado metabólico da célula, como também complementa estudos de expressão gênica e proteômica (Fraenkel, 1992; Ideker et al., 2001; Raamsdonk et al., 2001; Spinnler et al., 1996).

Apesar de sua importância, ainda não foram desenvolvidas muitas metodologias para a análise metabolômica. Isto se deve às características de grande parte dos metabólitos como alta polaridade, não-volatilidade e baixa detectabilidade, dentre outras. Além disso, o alto número de metabólitos diferentes presentes numa célula, cerca de 1000 , torna a análise complicada. Uma das primeiras análises metabolômicas em larga escala foi realizada pela 
metodologia de cromatografia gasosa acoplada a espectrometria de massas (GC-MS) (Fiehn et al., 2000a; Fiehn et al., 2000b). No entanto, esta metodologia é limitada pela necessidade de múltiplas derivatizações e devido a não-volatilização de muitos metabólitos (Soga et al., 2003). O método de cromatografia líquida acoplada espectrometria de massas (LC-MS) possui vantagens sobre GC-MS, pois não requer volatilização e pode trabalhar em temperaturas de análise mais baixas. No entanto, este método também possui limitações, principalmente no que tange a metabólitos polares (Tanaka et al., 2008). Para a análise de ácidos orgânicos, a técnica mais comumente utilizada é a de HPLC ("high performance liquid chromatography”) com detecção por UV (HPLC-UV), no entanto este método sofre com a baixa sensibilidade e seletividade e frequentemente requer derivatização, o que aumenta o tempo de análise.

O método de eletroforese capilar acoplada à espectrometria de massas (CE-MS) apareceu recentemente como uma poderosa ferramenta para a análise de espécies químicas carregadas (Cao and Moini, 1998; Soga and Heiger, 2000). A alta resolução obtida por esta técnica permitiu seu uso para determinação de diversos metabólitos aniônicos (Soga et al., 2002a; Soga et al., 2002b) e recentemente ela tem se demonstrado muito eficiente em análises metabolômicas em larga escala (Soga et al., 2003). Apesar de esta técnica ser bastante sensível e abrangente, no sentido de ser capaz de analisar um grande número de metabólitos, ela ainda não é amplamente utilizada pelos grupos de pesquisa devido às dificuldades de padronização das metodologias.

Uma alternativa comumente utilizada é a eletroforese capilar acoplada à detecção por fotometria indireta em UV (CE-UV). Trabalhos recentes descrevem o uso desta técnica para análise dos ácidos carboxílicos intermediários do ciclo de Krebs (Markuszewski et al., 2003) e de metabólitos da via glicolítica (Markuszewski et al., 2005). A desvantagem desta técnica 
com relação à de CE-MS é que são necessários padrões comerciais dos metabólitos analisados, enquanto que a detecção por espectrometria de massas não os requer.

Neste trabalho realizamos uma análise metabolômica parcial de B.emersonii através das técnicas de CE-MS, com a ajuda do Prof. Dr. Nilson A. de Assunção do Departamento de Ciências Exatas e da Terra da Universidade Federal de São Paulo. As análises foram realizadas no laboratório liderado pelo Prof. Dr. Etelvino J. H. Bechara no Instituto de Química da USP.

\subsection{Transformação de eucariotos mediada por Agrobacterium tumefasciens}

O sistema de transformação mediado por Agrobacterium tumefasciens é comumente utilizado em plantas. Entretanto, ultimamente este sistema tem se mostrado bastante útil em experimentos de transformação com diversos fungos, leveduras e até mesmo células humanas (Bundock et al., 1995; Chen et al., 2000; de Groot et al., 1998; Kunik et al., 2001; Zwiers and De Waard, 2001).

O gênero Agrobacterium pertence às bactérias gram-negativas de solo, encontradas comumente em associação com plantas, podendo causar diversas doenças. Infecções pela espécie Agrobacterium tumefaciens causam tumores em uma série de tipos vegetais, incluindo a maioria de dicotiledôneas, algumas monocotiledôneas e algumas gimnospermas (Matthysse, 2007). A indução do crescimento tumoral se dá devido à inserção de parte de seu DNA (T-DNA) localizado em um plasmídeo Ti (Tumor inducing) de $200 \mathrm{kpb}$.

Após a migração ao genoma hospedeiro, são expressos genes naturalmente presentes no T-DNA, que codificam enzimas que participam da síntese de hormônios reguladores de crescimento de plantas. Tal expressão resulta em um crescimento tecidual descontrolado e, consequentemente em tumorigênese. O plasmídeo Ti também contém uma região de virulência composta por uma série de genes vir, necessários à tumorigênese (Zhu et al., 
2000; Zupan et al., 2000). Os genes de virulência são induzidos por compostos fenólicos produzidos pelas plantas. Em laboratório, essa indução é feita com acetoseringona, mas em certas cepas super-virulentas como a EHA105 utilizada neste trabalho, essa indução não é necessária.

As proteínas codificadas pela região de virulência estão envolvidas em transporte, formação e provavelmente integração do T-DNA (Hooykaas and Beijersbergen, 1994; Zhu et al., 2000). A região T do plasmídeo Ti é flanqueada por duas repetições de 24 pb, que representa o sinal cis-atuante para o sistema de entrega à célula hospedeira, onde será inserida aleatoriamente no genoma.

Foi observado que toda a sequência do T-DNA pode ser deletada e substituída por outra, sem qualquer efeito deletério na transferência do DNA ao hospedeiro. Graças a isso, desenvolveu-se o sistema de vetor binário em que a região de virulência e o T-DNA são separados em dois plasmídeos distintos, permitindo uma manipulação genética mais fácil do vetor binário, agora menor, contando o T-DNA (Hoekema et al., 1983). A Figura 3, a seguir, ilustra o processo de transferência de T-DNA por A. tumefasciens. 


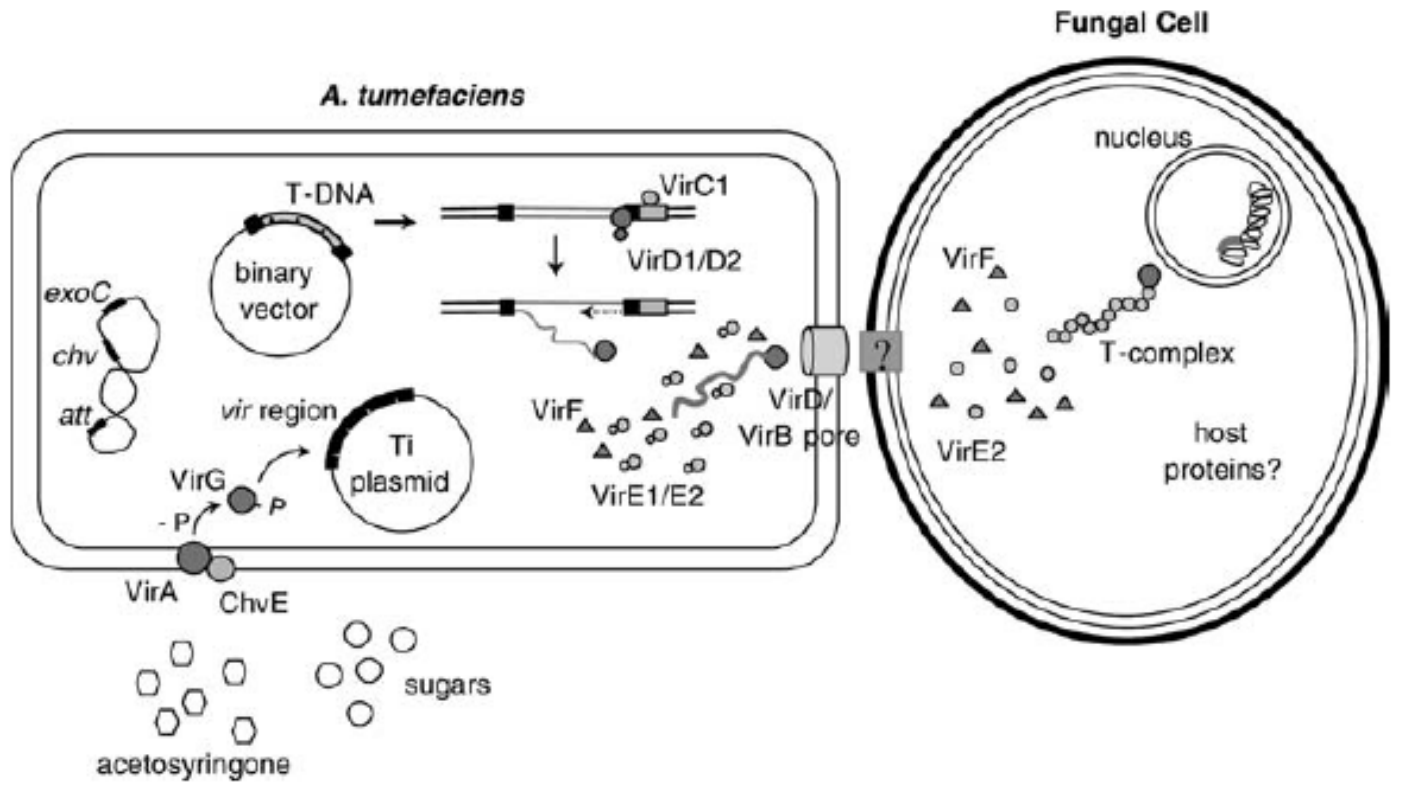

Figura 3: Visão esquemática do processo de transferência de T-DNA por Agrobacterium tumefaciens. (Adaptado de Michielse et al., 2005). 


\section{OBJETIVOS}

O propósito central deste trabalho foi investigar e comparar as respostas transcricionais do fungo Blastocladiella emersonii quando submetido à carência de oxigênio, através do uso da técnica de microarranjos de cDNA. Também procuramos obter evidências de um mecanismo sensor de hipóxia semelhante à via de HIF-1 de mamíferos, através de comparações entre as respostas transcricionais a hipóxia, carência de ferro (II) e hipóxia com tratamento prévio com a droga geldanamicina.

Como objetivo adicional, desenvolvemos um protocolo de transformação de Blastocladiella emersonii baseado na transferência de DNA pelo fitopatógeno Agrobacterium tumefasciens. 


\section{MATERIAIS E MÉTODOS}

\subsection{Cultivo de Blastocladiella emersonii}

Culturas de $B$. emersonii são renovadas semanalmente através do repique de zoósporos em placas de Petri contendo o meio PYG-ágar. As placas contendo zoósporos são mantidas a $28^{\circ} \mathrm{C}$ por cerca de $1 \mathrm{~h}$ até que estes tenham começado a germinar, aderindo à superfície do ágar. Em seguida a placa pode ser guardada em geladeira a $4^{\circ} \mathrm{C}$ por até uma semana, até que são então transferidas para uma estufa a $28^{\circ} \mathrm{C}$ até esporulação.

\subsection{Meios de cultura}

- $\quad$ PYG-ágar: peptona $0,125 \%$; extrato de levedura $0,125 \%$; glicose $0,15 \%$; ágar $1,5 \%$

- $\quad$ DM4 (Maia and Camargo, 1974): $\mathrm{CaCl}_{2}$ 1mM; MgSO4 $10 \mathrm{mM} ; \mathrm{FeSO}_{4} .7 \mathrm{H}_{2} \mathrm{O} 0,6$ $\mu \mathrm{g} \cdot \mathrm{mL}^{-1} ; \mathrm{CuSO}_{4} .5 \mathrm{H}_{2} \mathrm{O} \quad 0,1 \mu \mathrm{g} \cdot \mathrm{mL}^{-1} ; \mathrm{ZnSO}_{4} .7 \mathrm{H}_{2} \mathrm{O} \quad 0,2 \mu \mathrm{g} \cdot \mathrm{mL}^{-1} ; \mathrm{MnSO}_{4} \cdot \mathrm{H}_{2} \mathrm{O} \quad 0,2$ $\mu \mathrm{g} \cdot \mathrm{mL}^{-1}$; glicose $0,33 \%$; tiamina $0,04 \mu \mathrm{g} \cdot \mathrm{mL}^{-1}$; glicina $0,2 \mathrm{mM}$; L-histidina $0,13 \mathrm{mM}$; L-isoleucina 0,4 mM; L-lisina $\mathrm{HCl} 0,4 \mathrm{mM}$; L-metionina 0,1 mM; L-fenilalanina 0,2 mM; L-serina 0,2 mM; L-treonina 0,4 mM; L-triptofano 0,04 mM; L-tirosina 0,2 mM; L-valina 0,4 mM; L-arginina 0,24 mM; ácido glutâmico 2,7 mM; extrato de levedura $120 \mu \mathrm{g} \cdot \mathrm{mL}^{-1} ; \mathrm{NaH}_{2} \mathrm{PO}_{4} / \mathrm{Na}_{2} \mathrm{HPO}_{4} 1 \mathrm{mM}$ pH 6,8; tampão Tris-maleato 3,5 mM; pH 6,8. $\mathrm{O}$ pH do meio foi ajustado com $\mathrm{KOH} 1 \mathrm{M}$ e a concentração final de $\mathrm{K}^{+}$foi ajustada para $50 \mathrm{mM}$ com $\mathrm{KCl} 1 \mathrm{M}$.

- $\quad$ LB: triptona $1 \%$, extrato de levedura $0,5 \%, \mathrm{NaCl} 1 \%, \mathrm{pH} 7,5$

- $\quad$ LB-ágar: meio LB contendo 1,5\% ágar

- $\quad$ SOB: triptona $2 \%$, extrato de levedura $5 \%, \mathrm{NaCl} 0,06 \%, \mathrm{KCl} 0,02 \%, \mathrm{pH} 6,8)$

- $\quad \underline{\mathrm{MM}}: \mathrm{K}_{2} \mathrm{HPO}_{4} 3 \mathrm{~g} \cdot \mathrm{L}^{-1}, \mathrm{NaH}_{2} \mathrm{PO}_{4} 1 \mathrm{~g} \cdot \mathrm{L}^{-1}, \mathrm{NH}_{4} \mathrm{Cl} 1 \mathrm{~g} \cdot \mathrm{L}^{-1}, \mathrm{MgSO}_{4} \cdot 7 \mathrm{H}_{2} \mathrm{O} \quad 0.3 \mathrm{~g} \cdot \mathrm{L}^{-1}, \mathrm{KCl}$ $0.15 \mathrm{~g} \cdot \mathrm{L}^{-1}, \mathrm{CaCl}_{2} 0.005 \mathrm{~g} \cdot \mathrm{L}^{-1}, \mathrm{FeSO}_{4} \cdot 7 \mathrm{H}_{2} \mathrm{O} 0.0025 \mathrm{~g} \cdot \mathrm{L}^{-1}$, glicose $10 \mathrm{mM}$, pH 7.2 
- $\quad$ IM: meio MM contendo $40 \mathrm{mM}$ 2-[N-morpholino] ethanesulphonic acid (MES), $10 \mathrm{mM}$ glicose, $0.5 \%(\mathrm{w} / \mathrm{v})$ glicerol, $\mathrm{pH} 5.3$

- $\quad$ IM-ágar: meio IM contendo $5 \mathrm{mM}$ glicose e 1,5\% ágar

\subsection{Linhagens bacterianas}

- Escherichia coli - Cepa DH5a [supE44 lacU169 (80 lacZ4M15) hsdR17 recA1 endA11 gyrA96 thi-1relA1]

- Agrobacterium tumefasciens - Cepa EHA105

\subsection{Técnicas gerais de Biologia Molecular}

Procedimentos e técnicas comumente utilizadas na extração, manipulação e modificação de ácidos nucléicos foram realizados segundo descrito na literatura (Ausbel, 1992; Sambrook, 1989), ou, ainda, de acordo com protocolos específicos fornecidos em produtos, equipamentos e kits comerciais utilizados.

\subsection{Cultivo de B. emersonii em biorreator}

O cultivo foi realizado em $400 \mathrm{~mL}$ de meio DM4 (seção 4.2) em um biorreator equipado com eletrodos de $\mathrm{pH}$ e de oxigênio dissolvido (Rosemount Analytical ${ }^{\circledR}$ ). O pH do meio foi mantido constante através da adição automática de $\mathrm{NaOH}$ ou $\mathrm{HCl} 0.5 \mathrm{M}$, utilizando duas bombas peristálticas (Watson-Marlow ${ }^{\circledR}$ ). Uma mistura de ar e nitrogênio ultra-puro foi injetada no biorreator a uma vazão total fixada em $350 \mathrm{~mL} \cdot \mathrm{min}^{-1}$. Para a concentração de oxigênio dissolvido, dois fluxômetros $\left(\right.$ Aalborg $^{\circledR}$ ) foram usados para ajustar o fluxo de cada gás de acordo com a concentração de oxigênio medida. Para manter o $\mathrm{pH}$ e o oxigênio dissolvido constantes, foi utilizado o equipamento PLC ("Programable Logic Controller") (Unitronics ${ }^{\circledR}$ ), o qual opera automaticamente as bombas peristálticas e os fluxômetros para 
manter $\mathrm{pH}$ e oxigênio dissolvido nas condições programadas. Alíquotas de células foram retiradas com a ajuda de uma seringa estéril, filtradas sob vácuo em papel $3 \mathrm{~mm}$ $\left(\right.$ Whatman $\left.^{\circledR}\right)$, lavadas com água milli- $Q$ autoclavada, imediatamente congeladas sob nitrogênio líquido e guardadas em freezer $-70^{\circ} \mathrm{C}$.

\subsection{Experimentos de Hipóxia Gradual (HG)}

O reator, contendo $400 \mathrm{~mL}$ de meio DM4, foi inoculado com $6 \cdot 10^{5}$ zoósporos $\cdot \mathrm{mL}^{-1}$ em normóxia (70\% de saturação de oxigênio) e pH 6,8. As células foram cultivadas por 6,5 h a $28^{\circ} \mathrm{C}$, correspondendo à fase de crescimento vegetativo. Em seguida a saturação de oxigênio foi diminuída de seu valor inicial de 70\% (C70) para 35\% (C35), 17,5\% (C17.5), $5 \%(\mathrm{C} 5), 1 \%(\mathrm{C} 1)$ e $0 \%(\mathrm{C} 0)$, a cada $1 \mathrm{~h}$. Na etapa de $0 \%(\mathrm{C} 0)$, foi injetado somente nitrogênio ultrapuro por uma hora e, em seguida, o nível de oxigênio foi restabelecido ao seu valor inicial, 70\% de saturação (C70r). A Figura 4, a seguir, ilustra o experimento de hipóxia gradual (HG).

Ao final de cada etapa de uma hora, foram retiradas alíquotas de células para isolamento de RNA total. Também foram retiradas alíquotas de meio de cultura em diferentes tempos do experimento para a determinação das concentrações de glicose e lactato extracelular. $\mathrm{O}$ experimento foi realizado em triplicata e a amostra controle utilizada para os experimentos de microarranjos de cDNA foi sempre a C70. As hibridizações foram realizadas contra todas as outras condições: $\mathrm{C} 35, \mathrm{C} 17.5, \mathrm{C} 5, \mathrm{C} 1, \mathrm{C} 0$ e $\mathrm{C} 70 \mathrm{r}$. 


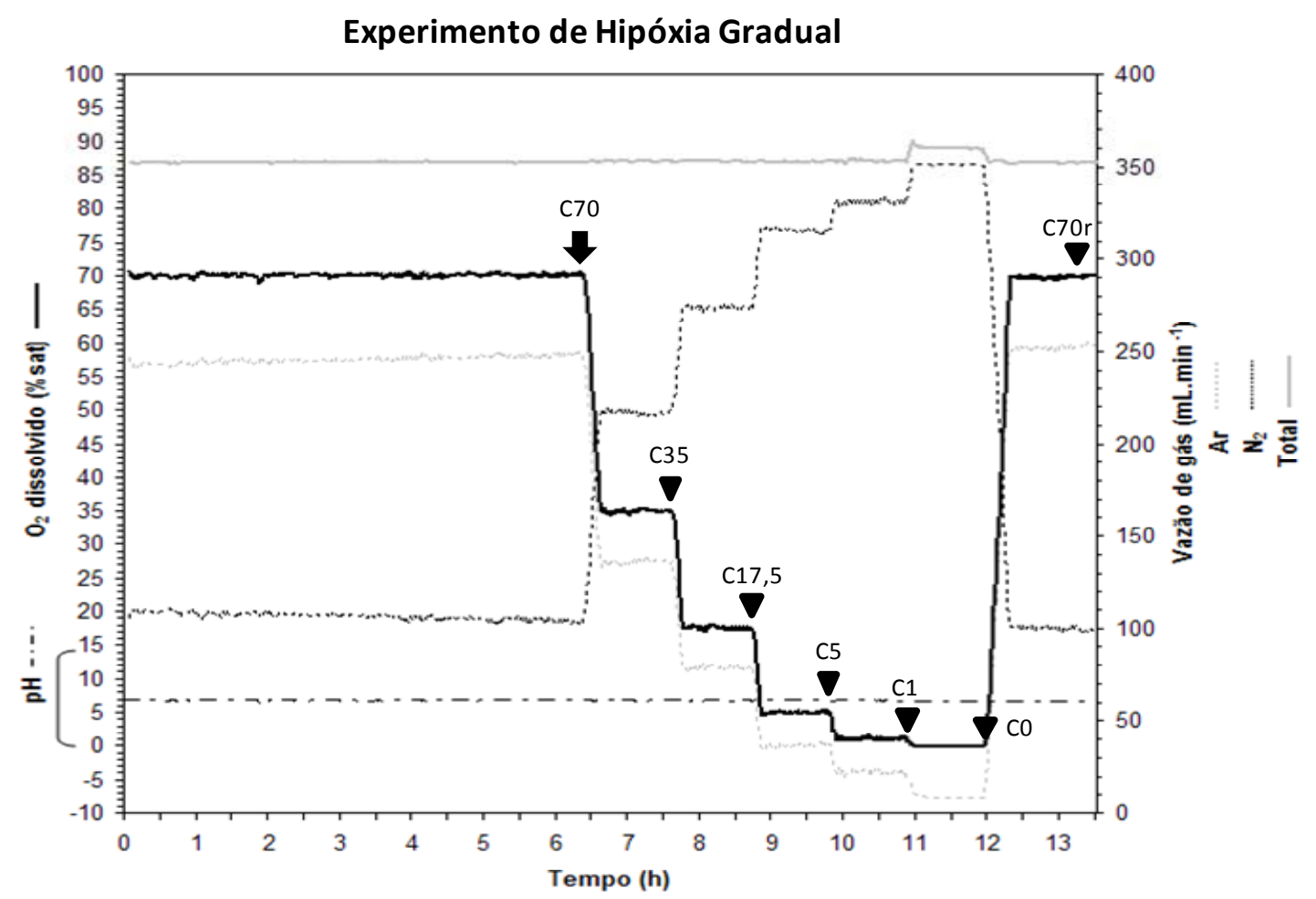

Figura 4: Experimento de Hipóxia Gradual. Após 6,5 horas de cultivo (seta), a saturação de oxigênio foi diminuída de seu valor inicial de 70\% (C70) para 35\% (C35), 17,5\% (C17.5), $5 \%(\mathrm{C} 5), 1 \%(\mathrm{C} 1)$ e $0 \%(\mathrm{C} 0)$, em períodos de $1 \mathrm{~h}$. Na etapa de $0 \%(\mathrm{C} 0)$, foi injetado somente nitrogênio ultrapuro por uma hora e, em seguida, o nível de oxigênio foi restabelecido ao seu valor inicial, 70\% de saturação (C70r). As pontas de setas indicam os pontos de retirada de alíquotas para isolamento de RNA total.

\subsection{Quantificação de glicose e lactato extracelular}

Foram retiradas alíquotas de $1 \mathrm{~mL}$ de cultura durante diferentes tempos do experimento de hipóxia gradual (seção 4.6), em três réplicas biológicas independentes. As alíquotas foram centrifugadas e os sobrenadantes congelados para posterior dosagem de glicose e lactato. As quantificações foram realizadas no equipamento YSI 2700 Select (Yellow Springs Instruments Co.), segundo as especificações do fabricante. Este aparelho utiliza uma enzima específica para o substrato de interesse, imobilizada entre duas membranas, uma de policarbonato e outra de acetato de celulose. O substrato a ser dosado é 
oxidado, produzindo peróxido de hidrogênio, que por sua vez é oxidado no eletrodo de platina, produzindo elétrons. Este fluxo de elétrons é proporcional à concentração de peróxido de hidrogênio e por sua vez à concentração de substrato.

\subsection{Experimentos de Hipóxia Direta (HD)}

As condições de cultivo foram idênticas às de hipóxia gradual (seção 4.6), mas ao invés de diminuir o oxigênio dissolvido gradualmente, a concentração foi levada rapidamente de normóxia (saturação de 70\%) para hipóxia 1\% (saturação de 1\%). A cultura foi mantida em hipóxia por 5 h e alíquotas foram retiradas após 1 hora (C1_1h) e 5 horas (C1_5h). Depois disto, os níveis de oxigênio foram restaurados para 70\% de saturação por 1 hora e uma alíquota foi também retirada (C70r_1h). O experimento foi realizado em triplicata e a amostra controle utilizada para os experimentos de microarranjo de cDNA foi sempre a C70. As hibridizações foram realizadas contra todas as outras condições: C1_1h, C1_5h e C70r_1h. A Figura 5, a seguir, ilustra o experimento de hipóxia direta (HD). 
Experimento de Hipóxia Direta

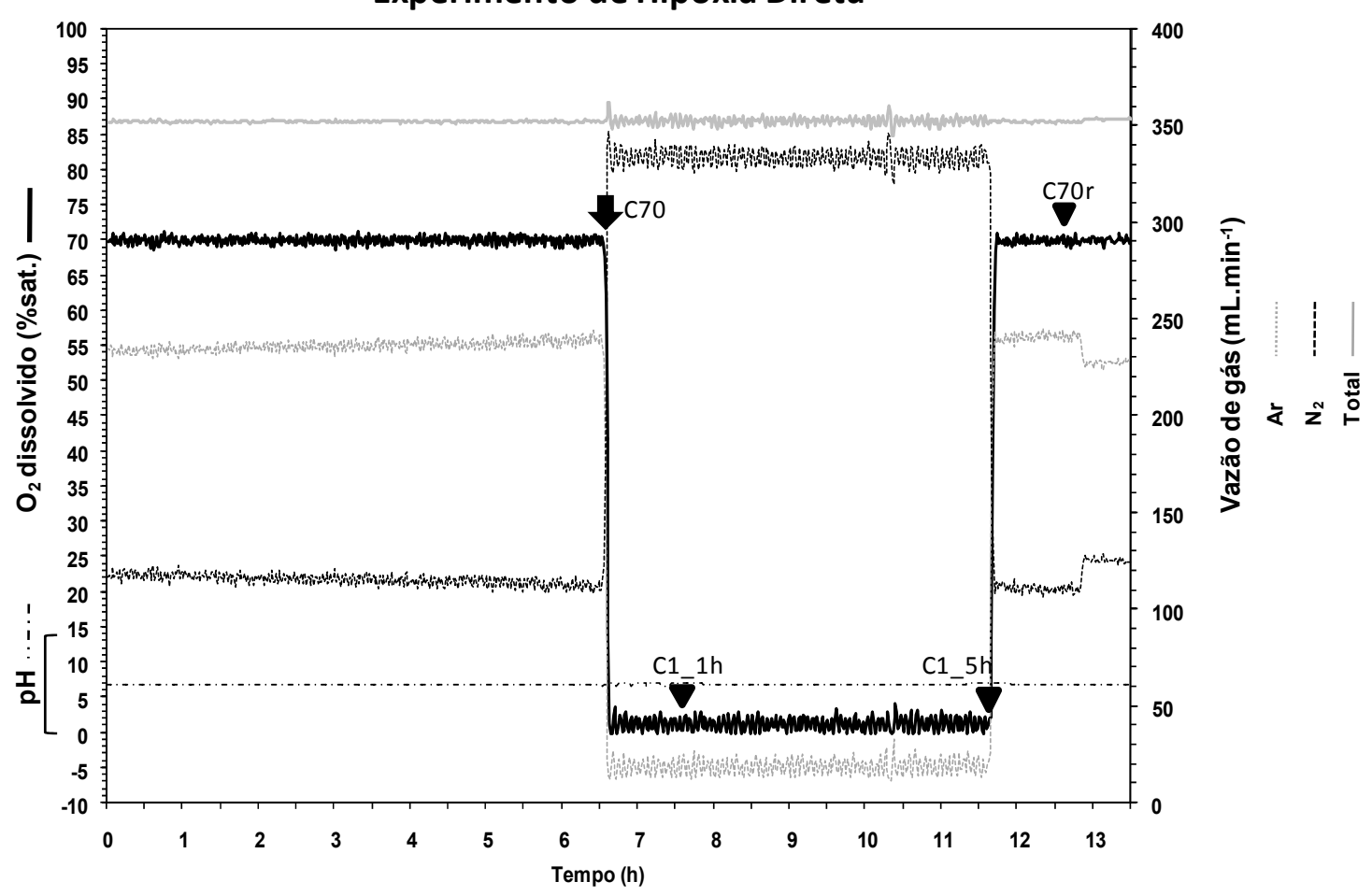

Figura 5: Experimento de Hipóxia Direta. Após 6,5 horas de cultivo (seta), a saturação de oxigênio foi diminuída de seu valor inicial de $70 \%$ para $1 \%$ de saturação. A cultura foi mantida em hipóxia por $5 \mathrm{~h}$ e alíquotas foram retiradas após 1 hora $\left(\mathrm{C} 1 \_1 \mathrm{~h}\right)$ e 5 horas (C1_5h). Em seguida, o nível de oxigênio foi restabelecido ao seu valor inicial, $70 \%$ de saturação (C70r). As pontas de setas indicam os pontos de retirada de alíquotas para isolamento de RNA total.

\subsection{Experimento de Carência de Ferro}

B. emersonii foi cultivada no mesmo biorreator utilizado para os experimentos de hipóxia. Foram inoculados $6 \cdot 10^{5}$ zoósporos $\cdot \mathrm{mL}^{-1} \mathrm{em} 400 \mathrm{~mL}$ de meio DM4 em condições de normóxia ( $70 \%$ saturação de $\left.\mathrm{O}_{2}\right)$, a $28^{\circ} \mathrm{C}$ e pH 6,8 . Após 6.5 h de crescimento adicionouse $150 \mu \mathrm{M}$ final de $2,2^{\prime}$-dipyridyl $\left(\right.$ Sigma $^{\circledR}$ ) e a cultura foi mantida nesta condição por mais $1 \mathrm{~h}$. Foram retiradas alíquotas de células para isolamento de RNA total em $\mathrm{T}=0 \mathrm{~h}$ (logo antes da adição de $2,2^{\prime}$-dipyridyl) e em $\mathrm{T}=1 \mathrm{~h}$ (1 hora após a adição da droga). O experimento foi 
realizado em triplicata e para as hibridizações dos microarranjos de cDNA utilizamos $\mathrm{T}=0 \mathrm{~h}$ contra $\mathrm{T}=1 \mathrm{~h}$.

\subsection{Experimento de Hipóxia com Geldanamicina}

Também no mesmo biorreator, foram inoculados $6 \cdot 10^{5}$ zoósporos $\cdot \mathrm{mL}^{-1} \mathrm{em} 140 \mathrm{~mL}$ em meio DM4 em normóxia (70\% saturação de $\mathrm{O}_{2}$ ), a $28{ }^{\circ} \mathrm{C}$ e pH 6,8. Após 5,5 h de crescimento foi adicionado $2 \mu \mathrm{M}$ de geldanamicina (Sigma). Após 1 hora nestas condições a concentração de oxigênio foi reduzida para $1 \%$ de saturação e foi mantida assim por uma hora. Em seguida foi retirada uma alíquota para isolamento de RNA total. Para a hibridação de microarranjos, usamos RNAs de células submetidas à 1 hora de hipóxia tratadas com geldanamicina, contra RNAs de células submetidas a 1 hora de hipóxia sem tratamento com geldanamicina (obtidos do experimento de hipóxia direta).

\subsection{Extração de RNA total de B. emersonii}

Para a extração de RNA, as amostras de células congeladas em freezer $-70^{\circ} \mathrm{C}$ foram maceradas sob nitrogênio líquido e transferidas para tubos eppendorf contendo $1 \mathrm{~mL}$ do reagente TriZol ${ }^{\circledR}\left(\right.$ Invitrogen $^{\circledR}$ ), de forma que o volume final fosse de aproximadamente 1,2 mL. As amostras foram homogeneizadas por rotação lenta por pelo menos 5 minutos e centrifugadas a $12000 \mathrm{~g}$ por 10 minutos a $4{ }^{\circ} \mathrm{C}$ para que os restos celulares se depositassem no fundo do tubo. Em seguida foi adicionado $200 \mu \mathrm{L}$ de clorofórmio incubou-se o tubo por 2 a 3 minutos em temperatura ambiente, após leve inversão manual. Após nova centrifugação a $12000 \mathrm{~g}$ por 15 minutos a fase aquosa superior foi separada e transferida para um tubo limpo e adicionou-se $500 \mu \mathrm{L}$ de isopropanol para precipitação do RNA total. As amostras foram mantidas por 10 minutos em temperatura ambiente $\left(25^{\circ} \mathrm{C}\right)$ e em seguida centrifugadas a $12000 \mathrm{~g}$ por 10 minutos a $4^{\circ} \mathrm{C}$. O RNA precipitado foi então lavado com etanol $70 \%$ e 
secado em SpeedVac. Finalmente as amostras de RNA foram solubilizadas em $100 \mu \mathrm{L}$ de água DEPEC e quantificadas por espectrofotometria direta (espectrofotômetro UV/Vis Ultrospec 2100 pro - Pharmacia $^{\circledR}$ ) e analisadas por eletroforese em gel de agarose em condições desnaturantes.

\subsection{Microarranjos de cDNA}

\subsubsection{Síntese de cDNA e marcação com fluoróforo para hibridização dos microarranjos}

Para a síntese e marcação de cDNAs foi utilizado o kit SuperScript ${ }^{\mathrm{TM}}$ Plus Indirect cDNA Labeling System (Invitrogen ${ }^{\mathrm{TM}}$ Life Technologies) com fluoróforos Alexa Fluor ${ }^{\circledR}$.

Para a reação de síntese foram utilizados $10 \mu \mathrm{g}$ de RNA total, $6 \mu \mathrm{L}$ de oligo(dT) ancorado, $1 \mu \mathrm{L}$ de solução de RNA Spike de controle para hibridização e água DEPC q.s.p $18 \mu \mathrm{L}$. Como se partiu de RNA total não foram adicionados à reação os hexâmeros aleatórios. Os tubos foram incubados por 5 minutos a $70^{\circ} \mathrm{C}$ e então transferidos para o gelo por pelo menos 1 minuto. Em seguida, adicionou-se a cada tubo $6 \mu \mathrm{L}$ de $5 \mathrm{X}$ First-Strand buffer, $1.5 \mu \mathrm{L}$ de $0,1 \mathrm{M}$ DTT, $1.5 \mu \mathrm{L}$ de dNTP mix, $1 \mu \mathrm{L}$ de $\mathrm{RNaseOUT}^{\mathrm{TM}}(40 \mathrm{U} / \mu \mathrm{L})$ e $2 \mu \mathrm{L}$ de SuperScript ${ }^{\mathrm{TM}}$ III RT $(400 \mathrm{U} / \mu \mathrm{L})$. A reação foi realizada por 3 horas a $46^{\circ} \mathrm{C}$. Após a hidrólise alcalina do RNA $\left(15 \mu \mathrm{L}\right.$ de $1 \mathrm{~N} \mathrm{NaOH}$ por 10 minutos a $\left.70^{\circ} \mathrm{C}\right)$ a solução foi neutralizada pela adição e mistura de $15 \mu \mathrm{L}$ de $1 \mathrm{~N} \mathrm{HCl}$. A purificação foi feita em placas de filtração Multiscreen Millipore. Adicionou-se a cada tubo $120 \mu \mathrm{L}$ de tampão de purificação e procedeu-se a centrifugação a $1.000 \mathrm{~g}, 1$ minuto e $25^{\circ} \mathrm{C}$. Após o descarte do filtrado, cada poço foi lavado 5 vezes com $200 \mu \mathrm{L}$ de etanol 80\% (as lavagens foram intercaladas por centrifugações a $1.000 \mathrm{~g}$, por 1 minuto e $25^{\circ} \mathrm{C}$, sendo a última centrifugação realizada a $3.500 \mathrm{rpm}$ por 5 minutos). O cDNA foi obtido a partir de duas eluições com $45 \mu \mathrm{L}$ de 10 mM Tris pH 8.0 a cada poço e centrifugação a 3.000 rpm por 5 minutos. Obtidas as soluções 
purificadas dos cDNAs, essas foram transferidas para tubos eppendorf e evaporadas em SpeedVac.

$\mathrm{Na}$ etapa de marcação, os cDNAs secos foram primeiramente dissolvidos em $5 \mu \mathrm{L}$ de tampão de acoplamento. Sem incidência de luz direta, os fluoróforos foram então ressuspensos em mistura de $2 \mu \mathrm{L}$ de DMSO e $3 \mu \mathrm{L}$ de água DEPC por agitação em vórtex e imediatamente adicionados ao tubo eppendorff contendo os cDNAs correspondentes àquela marcação. Os tubos com as reações de marcação foram mantidos por $1,5 \mathrm{~h}$ à temperatura ambiente em recipiente protegido da luz. As amostras controle foram marcadas com o fluoróforo Alexa Fluor ${ }^{\circledR} 555$ (fluoróforo Cy3; excitação a $555 \mathrm{~nm}$ ), enquanto as amostras teste foram marcadas com o fluoróforo Alexa Fluor ${ }^{\circledR} 647$ (fluoróforo Cy5; excitação a 647 nm). A etapa de purificação, seguinte à marcação, foi realizada segundo o mesmo protocolo usado na purificação dos cDNAs para marcação.

\subsubsection{Hibridização e leitura da fluorescência das lâminas de microarranjos}

Para a hibridização das lâminas de microarranjos com os cDNAs marcados, as amostras foram evaporadas no SpeedVac sob abrigo da luz e posteriormente cada par de amostras (controle e teste) foi dissolvida em 13,5 $\mu \mathrm{L}$ de água DEPC. A essa solução foram adicionados outros $13,5 \mu \mathrm{L}$ de tampão de hibridização e $27 \mu \mathrm{L}$ de formamida deionizada, perfazendo um total de $54 \mu \mathrm{L}$. Essa solução de hibridização foi aquecida a $92^{\circ} \mathrm{C}$ por 3 minutos em bloco termostatizado, rapidamente resfriada em gelo e centrifugada para aglutinação. Foi então dispensada sobre a lâmina de microarranjos (Figura 6) em forma de uma linha próxima a uma das colunas de sondas. Cuidadosamente uma lamínula foi colocada sobre a lâmina de forma a espalhar homogeneamente a solução por sobre todas as sondas do microarranjos. As lâminas de todas as condições de estudo sendo hibridizadas foram colocadas conjuntamente em uma câmara de hibridização de vidro (máximo de 5 
lâminas por câmara), contendo um algodão umedecido com água deionizada, e essa, por sua vez, foi incubada por um período de no mínimo 16 horas a $42^{\circ} \mathrm{C}$ em forno de hibridização.

Passado o período de hibridização, as lâminas foram submetidas à lavagem manual com intervalos de agitação de 10 minutos em agitador orbital entre uma solução de lavagem e outra, utilizando seqüencialmente as seguintes soluções: $1 \mathrm{x}$ SSC, $0,2 \%$ SDS a $55^{\circ} \mathrm{C} ; 0,1 \mathrm{x}$ $\mathrm{SSC}, 0,2 \%$ SDS a $55^{\circ} \mathrm{C}$ e novamente $0,1 \times \mathrm{SSC}, 0,2 \% \mathrm{SDS}$ a $55^{\circ} \mathrm{C}$. Após cada lavagem, as lâminas foram giradas em $180^{\circ}$ para uma lavagem mais homogênea das mesmas. Por fim, foi feita uma última lavagem com solução $0,1 \times \mathrm{SSC}$, à temperatura ambiente $\left(25^{\circ} \mathrm{C}\right)$ com agitação por 1 minuto. Em seguida, as lâminas foram mergulhadas quatro vezes em água deionizada, e então secadas sob jato de nitrogênio ultra-puro.

A leitura das fluorescências das sondas foi realizada em escaner Generation III DNA Scanner (GE Healthcare) dedicado à leitura de lâminas de microarranjos segundo o protocolo padrão para obtenção de imagens. Foi feita, para cada lâmina, uma leitura com ganho de sinal da CCD de $750 \mathrm{~V}$. Os arquivos referentes às imagens das lâminas foram então submetidos à extração dos dados de fluorescência para cada sonda dos microarranjos. 


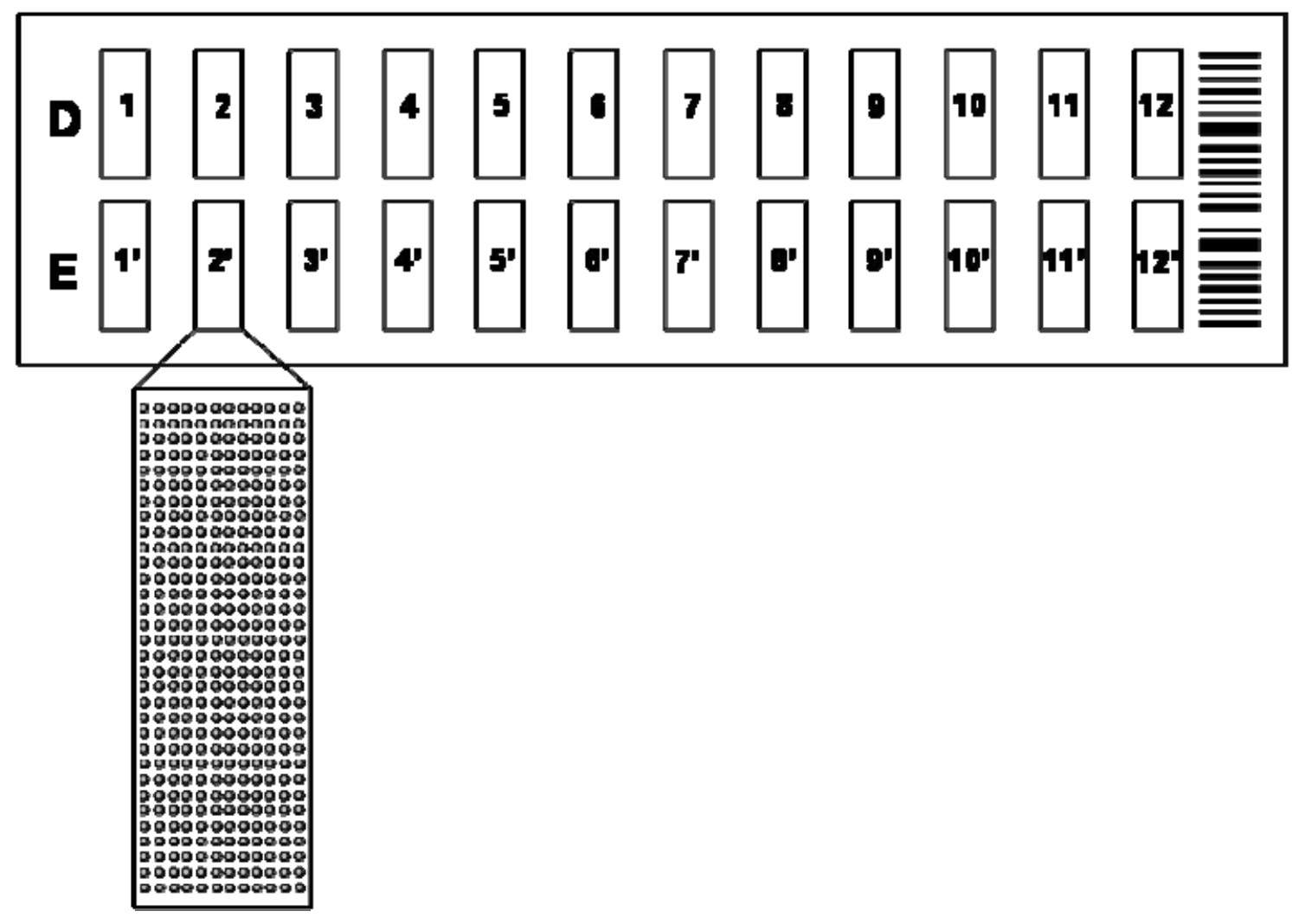

Figura 6: Desenho esquemático da lâmina de microarranjo de DNA. Os lados, esquerdo (E) e direito (D), da lâmina são idênticos, cada um contém 12 subarranjos compostos por 12 linhas e 32 colunas. A linha 12 de cada subarranjo contém um conjunto de 23 genes artificiais denominados Scorecard.

\subsubsection{Quantificação da fluorescência emitida nos microarranjos e extração dos dados}

As intensidades de fluorescência foram quantificadas pelo software ArrayVision ${ }^{\circledR} 6.0$ (Image Research) através do Median Artifact Removed Density (MARMDens) que consiste em uma medida de densidade do sinal de fluorescência excluindo pixels que apresentem sinal acima ou abaixo de 4 desvios absolutos da mediana (MAD), proporcionando a exclusão de pixels que representam poeira ou artefatos de hibridização. Neste modelo, o background é quantificado como sendo uma moldura com largura de 2 pixels em torno do spot e a mediana do seu valor é subtraída do sinal bruto. 
Para fins de controle de qualidade foi pedido ao programa que colocasse "flags" automaticamente, tanto para sondas quanto para o fundo, em que $20 \%$, ou mais, dos pixels ultrapassassem os limites inferiores ou superiores de detecção.

Após o alinhamento dos spots e os cálculos dos dados, foi realizada uma verificação visual das imagens das lâminas em ambos os canais de fluorescência. Sondas suspeitas de terem o sinal influenciado por manchas ou riscos receberam também "flags" manuais. Os dados foram extraídos e gravados em arquivos texto (.txt) de planilhas do MS Excel $\left(\right.$ Microsoft $\left.^{\circledR}\right)$.

\subsubsection{Normalização dos dados de Microarranjo}

A normalização dos dados foi realizada para corrigir artefatos na incorporação dos fluoróforos e diferenças na intensidade de fluorescência entre os fluoróforos (Quackenbush, 2001; Yang et al., 2002). Para isso, utilizamos o LOWESS - LOcally WEighted regreSSsion para ajustar os dados de expressão gênica, assumindo como hipótese que a maioria dos genes não deve apresentar diferença entre as duas condições. A função LOWESS está implementada no pacote estatístico R (www.r-project.org) e consiste em uma série de regressões lineares locais que se juntam para formar um ajuste global não-linear. A normalização foi feita no espaço $\mathrm{M} \mathrm{x} \mathrm{S} \mathrm{onde} \mathrm{M} \mathrm{é} \mathrm{a} \mathrm{razão} \mathrm{da} \mathrm{intensidade} \mathrm{de} \mathrm{fluorescência} \mathrm{das}$ duas medidas para cada spot $\left[\mathrm{M}=\log _{2}\left(\mathrm{I}_{\text {teste }} / \mathrm{I}_{\text {referência }}\right)\right]$ e $\mathrm{S}$ representa a média da intensidade total do spot $\left[\mathrm{S}=\log _{2}\left(\mathrm{I}_{\text {teste }} / 2+\mathrm{I}_{\text {referência }} / 2\right]\right.$ (Koide et al., 2006).

\subsubsection{Determinação dos genes diferencialmente expressos}

Para a identificação de quais genes haviam sido diferencialmente expressos foram utilizadas ferramentas baseadas no teste estatístico HTself (http://blasto.iq.usp.br/ rvencio/HTself) (Vencio and Koide, 2005), que se vale da determinação de limites de corte dependentes da razão de intensidades de fluorescência em 
hibridizações homotípicas (isto é, uma amostra hibridizada contra ela mesma) e do uso de métodos não paramétricos. A função de probabilidade de densidade $(p d f)$ nula foi definida localmente para $\mathrm{M}$ em um intervalo de $\mathrm{S}$, no espaço $\mathrm{M}$ x S, através do método de Estimador de Densidade Kernel do tipo gaussiano. Para tanto, utilizou-se como dados para análise a medida de densidade de fluorescência normalizada obtida na hibridização homotípica realizada com a amostra controle (RNA total do ponto de normóxia - C70). Após estimar a $p d f$ nula, os limites de corte locais foram definidos como aqueles onde se encontravam $98 \%$ dos valores de M num determinado intervalo de S. O gráfico a seguir (Figura 7), do espaço M x S, apresenta os limites de corte definidos com os dados da hibridização homotípica realizada. 


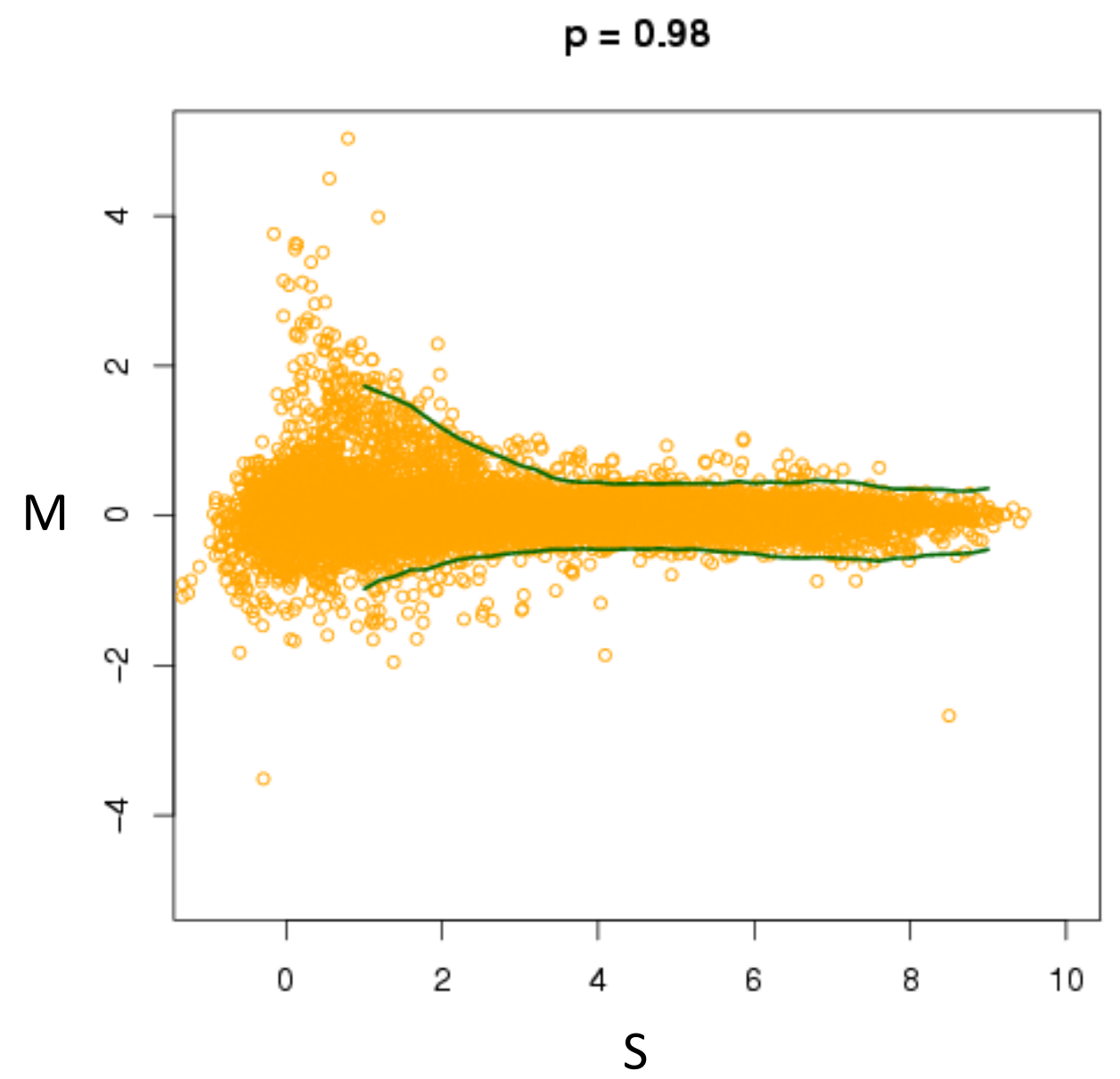

Figura 7: Hibridização self-self de Hipóxia Gradual e Direta. Gráfico do espaço M x S onde foram colocados os valores da medida de densidade de fluorescência normalizada obtida na hibridização homotípica (C70 vs C70). A linha contínua determina os limites de corte locais com a presença de $98 \%$ (p) dos pontos. $\mathrm{M}=\log 2(\mathrm{C} 70 / \mathrm{C} 70)$ e $\mathrm{S}=\log 2(\mathrm{C} 70 / 2+\mathrm{C} 70 / 2)$.

Em seguida, aplicamos estes limites de corte a todos os dados reais das demais hibridizações, para as três réplicas. Para cada sonda foi calculada a mediana do valor de $\mathrm{M} \mathrm{e}$ a percentagem das réplicas que se encontravam em um de três grupos de expressão: Induzido, quando $\mathrm{M}$ se encontrava acima do limite de corte positivo naquele ponto de $\mathrm{A}$; Reprimido, quando M se encontrava abaixo do limite de corte negativo naquele ponto de S; e Invariável, quando $\mathrm{M}$ se encontrava entre os limites positivo e negativo naquele ponto de 
S. Foram considerados diferencialmente expressos aqueles genes nos quais pelo menos $66 \%$ das sondas (pelo menos duas em três) estivessem nos grupos Induzido ou Reprimido.

\subsubsection{Agrupamento dos genes diferencialmente expressos segundo o perfil de expressão}

Para realizar o agrupamento dos genes, de acordo com o perfil de expressão no experimento de hipóxia gradual, usando a medida de distância euclidiana, utilizou-se o algoritmo K-means, disponível como uma das ferramentas de análise de dados de microarranjos do programa SpotWhatR (http://blasto.iq.usp.br/ tkoide/SpotWhat) (Koide et al., 2006).

K-means é um algoritmo interativo de agrupamento, onde o número de grupos é uma das entradas do algoritmo e pode ser definido pelo usuário. Estes são representados por centróides, o centro do grupo. $\mathrm{O}$ algoritmo minimiza a somatória das distâncias de cada objeto ao centróide correspondente. Em cada interação, cada gene é designado para o centróide mais próximo e os novos centróides são computados com base na distribuição dos genes. Estes passos são repetidos até que não haja mais mobilidade dos genes entre os diferentes grupos.

Para realizar as análises de agrupamento, foi fornecido ao programa um arquivo contendo uma coluna de identificação dos clones (rotulada como ID) e as colunas correspondentes às condições experimentais de hipóxia gradual $(\mathrm{C} 70 ; \mathrm{C} 35 ; \mathrm{C} 17,5 ; \mathrm{C} 5 ; \mathrm{C} 1$; C0 e C70r), contendo os logaritmos da razão de expressão (mediana do valor de M). Com isso é possível visualizar agrupamentos semelhantes de perfis de expressão ao longo da série. O perfil de expressão dos genes diferencialmente expressos em hipóxia gradual, distribuídos em oito agrupamentos será apresentado na seção 5.1.4. 


\subsubsection{Determinação das categorias do Consórcio Gene Ontology mais representadas entre os genes diferencialmente expressos}

A forma mais comum de análise de terminologia é a classificação de genes em categorias, das quais o esquema utilizado neste trabalho é o proposto pelo "The Gene Ontology Consortium” (GO). Os três princípios organizacionais do GO são: Função molecular (m), Processo biológico (b) e Componente celular (c). Um produto gênico tem uma ou mais funções moleculares e é usado em um ou mais processos biológicos e pode estar associado com um ou mais componentes celulares. Por exemplo, o produto gênico citocromo c pode ser descrito pelos seguintes termos: atividade transportadora de elétrons (F); fosforilação oxidativa e indução da morte celular (P); matriz mitocondrial e membrana mitocondrial interna $(\mathrm{C})$.

Para a identificação de quais categorias do GO haviam sido mais representadas nos diferentes agrupamentos ( $K$-means) e também nas diferentes condições de oxigênio estudadas, foi utilizado o teste estatístico BayGO (http://blasto.iq.usp.br/ tkoide/BayGO) (Vencio et al., 2006).

O aplicativo BayGO foi desenvolvido com o objetivo de encontrar categorias funcionais (de acordo com a terminologia do Gene Ontology) altamente representadas em uma lista de genes diferencialmente expressos. Este programa recebe como dados de entrada uma tabela gene-para-GO e retorna uma tabela GO-para-gene. A tabela gene-para-GO foi montada após o BlastX das seqüências depositadas no microarranjo contra uma base de dados local. O programa resume os dados apresentando o número de genes em cada categoria funcional do GO e calcula a medida de associação entre ser diferencialmente expresso e pertencer a uma dada categoria GO. Esta medida de associação, denominada G, é calculada como descrito por (Goodman and Kruskal, 1954). Valores próximos a 1,0 indicam uma forte associação. Para determinar a significância estatística de uma dada 
associação, ela é comparada com a associação $\mathrm{G}^{*}$, obtida a partir de listas de genes simuladas ao acaso. Nós consideramos que uma categoria é altamente representada se o valor da probabilidade $\mathrm{P}=\operatorname{Pr}\left(\mathrm{G}^{*}>\mathrm{G}\right)$ for menor ou igual a 0,05 .

\subsubsection{Depósito dos dados de microarranjo}

Os dados de microarranjos apresentados nesta tese foram depositados na base de dados "Gene Expression Omnibus" (GEO; http://www.ncbi.nlm.nih.gov/geo/) do NCBI e podem ser consultados através do número de acesso GSE17524 (http://www.ncbi.nlm.nih.gov/geo/query/acc.cgi?acc=GSE17524).

\subsection{Análise da expressão gênica por RT-PCR quantitativo}

Foi utilizado o método de RT-PCR quantitativo para a validação dos dados de microarranjo e para avaliar os perfis transcricionais de genes de interesse para este estudo, que não estão presentes nas lâminas de microarranjo. Foram desenhados oligonucleotídeos específicos para os genes selecionados (Tabela 1), utilizando-se o programa Primer Express 3.0 (Applied Biosystems). O programa tem como princípio a otimização do desenho de oligonucleotídeos para a reação de RT-PCR quantitativo (ou PCR em tempo real), considerando-se que o produto de PCR tenha entre 50 e 150 pb e sua temperatura de dissociação seja em torno de $80^{\circ} \mathrm{C}$. As reações foram realizadas utilizando-se o kit $\mathrm{SYBR}^{\circledR}$ Green PCR Master Mix (Applied Biosystems) em o equipamento GeneAmp 5700 Sequence Detection System (Applied Biosystems).

O RNA total $(5 \mu \mathrm{g})$, previamente tratado com DNase, foi utilizado para síntese de cDNA, segundo as especificações do fabricante do kit SupersriptII (Invitrogen). Os cDNAs obtidos foram diluídos para $125 \mu \mathrm{L}$ com água milliQ tratada com DEPEC. Em seguida, foi realizada a reação de PCR quantitativo utilizando-se $5 \mu \mathrm{L}$ de cDNA como molde, 1,6 $\mu \mathrm{M}$ de 
oligonucleotídeos direto e reverso e $10 \mu \mathrm{L}$ de $\mathrm{SYBR}^{\circledR}$ Green, sob os seguintes parâmetros: $50^{\circ} \mathrm{C}$ por $2 \mathrm{~min}, 95^{\circ} \mathrm{C}$ por $10 \mathrm{~min}, 40$ ciclos de $95^{\circ} \mathrm{C}$ por $15 \mathrm{seg}$ e $60^{\circ} \mathrm{C}$ por $1 \mathrm{~min}$. A especificidade dos produtos amplificados foi avaliada pela análise das curvas de dissociação geradas pelo aparelho.

Tabela 1: Oligonucleotídeos utilizados nos experimentos de qRT-PCR para validação dos microarranjos e análise da expressão gênica de genes ausentes nas lâminas.

\begin{tabular}{|c|c|c|c|}
\hline Clone ID & Anotação Putativa & Oligo direto (5' - 3') & Oligo reverso (5' - 3') \\
\hline \multicolumn{4}{|c|}{ Validações dos microarranjos } \\
\hline BeE60H26A05 & $\begin{array}{l}\text { Related to phosphatidylserine } \\
\text { decarboxylase }\end{array}$ & GTTCCCGCTGACCAACAAGA & AGACGAGGCGCAGGATGA \\
\hline BeE30N15A04 & $\begin{array}{l}\text { Eukaryotic translation initiation } \\
\text { factor } 3\end{array}$ & TGCACCGCCATCATCGT & TCGGGCAGGAAGATGTTGA \\
\hline $\mathrm{BeE} 60 \mathrm{H} 32 \mathrm{G} 06$ & $\begin{array}{l}\text { Trafficking protein particle } \\
\text { complex subunit } 5\end{array}$ & GGTCCCAAAGGAAATGTAGC & CGTCGAGAATAGCATCCATG \\
\hline BeE30N19D09 & $\begin{array}{l}\text { 5-methyl } \\
\text { tetrahydropteroyltriglutamate-- } \\
\text { homocysteine } \\
\text { methyltransferase }\end{array}$ & GAGATCGGGCTCGACATCAT & CACCCGTGCTGCGTGAA \\
\hline BeG120N15B05 & $\begin{array}{l}\text { S-adenosylmethionine } \\
\text { synthetase }\end{array}$ & ACGGTCGAGTACAAGATGGACAA & AGTGCTGGGTCGAGATGACAA \\
\hline BeE60N03G10 & $\begin{array}{l}\text { cyclopropane-fatty-acyl- } \\
\text { phospholipid synthase }\end{array}$ & TCAACTTTTTGCGCATGGACTA & GCCATTTCAAGGCAGGTGAT \\
\hline BeG30N15D05 & carbonic anhydrase protein & ACAGATCGACCCCGAGTTCA & AACAGCAAATGGCGCAAGAC \\
\hline BeG60N06G05 & delta-9 fatty acid desaturase & CGCTCTACGGCGTTTCGA & CCCGGTGATCAAGTAGTAGATGAA \\
\hline BeE120N03E01 & D-lactate dehydrogenase & TCATCTGCCAGGACGTGTACA & AGCGTGTCCATCTCCACGTACT \\
\hline BeE120N37A02 & $\begin{array}{l}\text { Putative glutathione S- } \\
\text { transferase }\end{array}$ & AGGTCGAGTACCCGGACATG & GAACTTGACCCAGTCCTTTTCG \\
\hline BeE60H30A07 & $\begin{array}{l}\text { Heat shock protein } 90 \\
\text { (Fragment) }\end{array}$ & GCGTCTTCATCATGGACAAC & GAGTCGACGATGCCCTTGAC \\
\hline BeE60H06B09 & Histone H2A & AACAAGTTGCTCGCCAGTGTT & GGCAGCAACTGAGGTGCCAAT \\
\hline \multicolumn{4}{|c|}{ Genes ausentes nos microarranjos } \\
\hline BeE90N03A12 & $\begin{array}{l}\text { 6-phosphofructokinase } \\
\text { subunit alpha }\end{array}$ & GCCACCATCTCCAACAACGT & GCCGACTGCTTCAGCTTGTC \\
\hline BeE90D13G07 & $\begin{array}{l}\text { 6-phosphofructokinase beta } \\
\text { subunit }\end{array}$ & CGCCTTCGACACGTTCGT & CGTCACCACCACCCACAAC \\
\hline BeG30N12D06 & triosephosphate isomerase & ATCAАCСАССТААТССАAАAATGAC & AACTTGGTCGAGCCGTTGAG \\
\hline BeCSAS379 & $\begin{array}{l}\text { pyrophosphate--fructose 6- } \\
\text { phosphate 1- } \\
\text { phosphotransferase }\end{array}$ & CGCGATTGCCAAGGAGATT & CTTTTGGTAGGCAATGTCATTGTC \\
\hline BeCSAS336 & $\begin{array}{l}\text { Fructose-1,6-bisphosphatase } \\
\text { (FBPase) }\end{array}$ & GATCTTCATCAACTCGCTCAAGTC & GTCGGGACCACGATGATCTC \\
\hline
\end{tabular}




\subsection{Análise de metabólitos por Eletroforese Capilar}

\subsubsection{Princípio do método}

O processo de eletroforese é definido como a migração diferencial de íons por atração ou repulsão num campo elétrico. Em termos práticos um eletrodo positivo (ânodo) e um negativo (cátodo) são colocados numa solução contendo íons e, quando uma voltagem é aplicada pelos eletrodos, íons solúveis de diferentes cargas elétricas se moverão pela solução na direção do eletrodo de carga oposta. A Eletroforese Capilar consiste em aplicar a técnica de eletroforese em capilares, normalmente de 25 a $100 \mu \mathrm{m}$ de diâmetro interno (d.i.).

\subsubsection{Análise de metabólitos catiônicos por CE-MS}

A separação dos metabólitos catiônicos foi realizada com o equipamento de eletroforese capilar P/ACE MDQ (Beckman Coulter, CA, USA). Para a detecção foi utilizado o espectrômetro de massas Thermo Finnigan, model LCD Ion Max Advanced with ESI source and Ion trap analyzer (MA, USA). A eletroforese foi realizada com capilar de sílica fundida (Polymicro Technologies, AZ, USA) com $50 \mu \mathrm{m}$ d. i. x $70 \mathrm{~cm}$ de comprimento total. Uma solução de ácido fórmico $1 \mathrm{M}$ foi usada como eletrólito para a separação. Antes de cada injeção, o capilar foi pré-condicionado por 3 min com hidróxido de amônio 1 M, 2 min com água e finalmente 5 min com a solução eletrólito. As amostras foram injetadas a uma pressão de 0.5 psi por $5 \mathrm{~s}$. O campo elétrico efetivo aplicado foi de $256 \mathrm{~V} \cdot \mathrm{cm}^{-1}$ e a temperatura do capilar foi mantida a $25^{\circ} \mathrm{C}$, com interface no modo "sheathflow". O líquido auxiliar, composto de 50/49,5/0.5 \% (v/v) de água/metanol/ácido acético, foi injetado no CE-ESI-MS por uma bomba Gilson Pump Model 402 (MI, USA) num fluxo de $10 \mu \mathrm{L} \cdot \mathrm{min}^{-1}$, ao redor do sistema CE para promover uma conexão elétrica entre a extremidade do CE e o sistema MS para ajudar na dessolvatação, vaporização e resultar num aerosol estável. Os experimentos MS e MS/MS foram realizados no modo íon positivo e 
uma voltagem de $4.5 \mathrm{kV}$ do spray iônico foi aplicada em cada injeção via CE. Número de "microscans" = 3, duração dos "microscans" $=200 \mathrm{~ms}$, temperatura do capilar $=275^{\circ} \mathrm{C}$, voltagem do spray $=27 \mathrm{~V}$, "tube lens offset" $=-8 \mathrm{~V}$. A calibração do espectrômetro de massas foi realizada pela infusão direta pelo CE numa pressão de 10 psi com uma solução de L-histidina $20 \mu \mathrm{mol} \cdot \mathrm{L}^{-1}$.

\subsubsection{Preparação dos extratos metabólicos}

B. emersonii foi cultivada nas mesmas condições do experimento de hipóxia gradual (seção 4.6) e foram retiradas alíquotas de normóxia (C70), anóxia (C0) e reoxigenação (C70r). As células foram filtradas em papel $3 \mathrm{~mm}\left(\right.$ Whatman $\left.^{\circledR}\right)$, lavadas com água milli- $Q$ e congeladas rapidamente em nitrogênio líquido. As células congeladas foram maceradas em cadinho sob nitrogênio liquido e o fino pó foi então transferido para um tubo falcon de 15 $\mathrm{mL}$ contendo $2 \mathrm{~mL}$ de metanol gelado (em freezer $-20^{\circ} \mathrm{C}$ ) para inativação de enzimas. Após incubação de 5 minutos em gelo, foram adicionados $2 \mathrm{~mL}$ de água milli- $Q$ gelada (em refrigerador a $4^{\circ} \mathrm{C}$ ), contendo $0,2 \mathrm{mM}$ de imidazol e PIPES (piperazina-N,N'-bis-[ácido etanossulfônico]) como padrões internos. A mistura foi homogeneizada em vórtex e, em seguida, foram adicionados $3 \mathrm{~mL}$ de clorofórmio gelado (em freezer $-20^{\circ} \mathrm{C}$ ). A mistura foi novamente homogeneizada em vórtex para remover fosfolipídeos liberados de membranas. A emulsão resultante foi centrifugada a $12000 \mathrm{rpm}$, a $4^{\circ} \mathrm{C}$ por 15 minutos. Uma alíquota de $100 \mu \mathrm{L}$ foi retirada do sobrenadante para posterior quantificação de proteínas totais. $\mathrm{O}$ restante do sobrenadante foi filtrado em tubos Ultrafree-MC filter, 5000 NMWL (Millipore, Bedford, MA, USA) para remover proteínas. A solução filtrada foi liofilizada em SpeedVac e guardada em freezer $-80^{\circ} \mathrm{C}$. No momento da análise as amostras foram solubilizadas em água milli- $Q$ de forma que as concentrações de proteínas totais ficassem igualadas. 


\subsubsection{Quantificação de proteínas totais - Método Bradford}

Para a quantificação de proteínas totais nos extratos metabólicos utilizamos o reagente de Bradford $\left(\right.$ Sigma $\left.^{\circledR}\right)$. O protocolo consiste em adicionar num tubo de ensaio o volume desejado de amostra e tampão Tris-HCl $25 \mathrm{mM}$, pH 7.5, para um volume final de $800 \mu \mathrm{L}$. Em seguida adiciona-se $200 \mu \mathrm{L}$ do reagente de Bradford e incuba-se a $25^{\circ} \mathrm{C}$ por 5 min, após homogeinização em vórtex.

Inicialmente foi feita uma curva-padrão utilizando soro bovino fetal (BSA), a partir da qual foram calculadas as concentrações de proteínas dos extratos metabólicos.

\subsection{Transformação de B. emersonii por Agrobacterium tumefasciens}

\subsubsection{Construção do Vetor Binário pBINPLUS-Hph}

O fragmento de 2,4 kpb proveniente do plasmídeo pCSN43 (Staben et al., 1989) (Figura 8A), contendo o gene de resistência a higromicina B de Escherichia coli, (higB ${ }^{r}$ ) que codifica a enzima higromicina fosfotransferase (Hph), foi cortado com a enzima SalI e inserido no interior da seqüência do T-DNA presente no vetor binário pBINPLUS (van Engelen et al., 1995) (Figura 8B). 
A

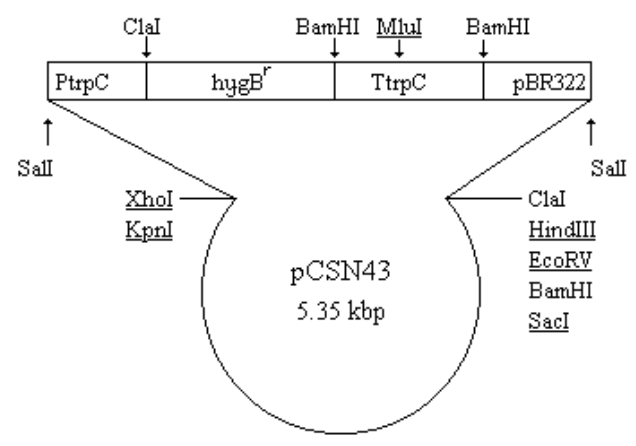

B

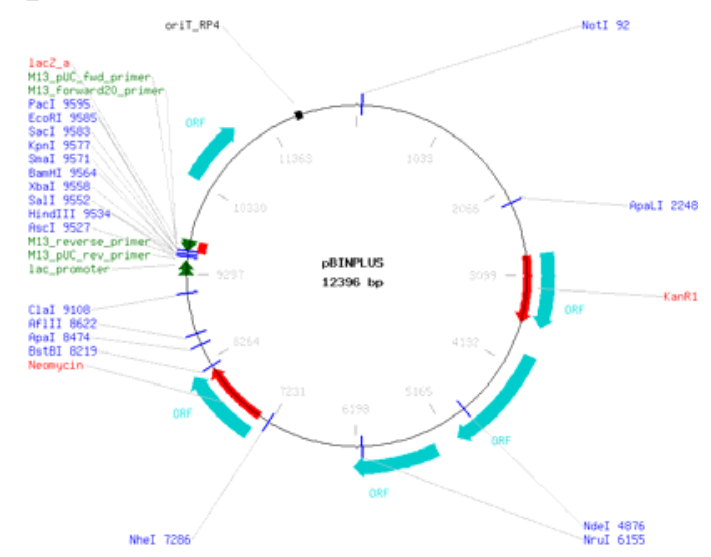

Figura 8: Plasmídeos utilizados na construção do vetor binário pBINPLUS-Hph. A: pCSN43 (Staben et al., 1989). B: pBINPLUS (van Engelen et al., 1995).

\subsubsection{Protocolo de transformação}

\section{Condições de cultivo para Agrobacterium tumefasciens}

Utilizamos a cepa EHA105 de A. tumefasciens, a qual possui um plasmídeo Ti pTiEHA105. Esse plasmídeo possui uma deleção completa do T-DNA, além de possuir os genes vir supervirulentos do tipo succinamopina (Hood et al., 1993). Primeiramente ela é transformada com o vetor binário pBINPLUS- $h p h$ por eletroporação e selecionada em placas de LB-ágar contendo $50 \mu \mathrm{g} \cdot \mathrm{mL}^{-1}$ de Canamicina.

Cultiva-se uma colônia isolada overnight a $28{ }^{\circ} \mathrm{C}$ em $5 \mathrm{~mL}$ de meio mínimo MM (seção 4.2), contendo $50 \mu \mathrm{g} \cdot \mathrm{mL}^{-1}$ de Canamicina,. Em seguida, $1 \mathrm{~mL}$ da cultura é lavada duas vezes com $1 \mathrm{~mL}$ de meio de indução IM (seção 4.2), 10 vezes diluída no mesmo meio (IM) e incubada a $28{ }^{\circ} \mathrm{C}$ sob agitação por cerca de 5 horas até uma $\mathrm{DO}_{600}$ de aproximadamente 0,25 . As células são então lavadas duas vezes com $1 \mathrm{~mL}$ de água milliQ estéril e ressuspendidas no mesmo volume. 


\section{Co-cultivo e seleção dos transformantes}

Aproximadamente $5 \cdot 10^{-7}$ zoósporos de $B$. emersonii foram inoculados em $50 \mathrm{~mL}$ de meio DM4 (seção 4.2) e incubados a $28{ }^{\circ} \mathrm{C}$ por 1,5 horas sob agitação, até o início da germinação. As células foram coletadas por centrifugação (12000 rpm), lavadas com água milliQ estéril uma vez e ressuspendidas com a suspensão de A. tumefasciens preparada anteriormente. A mistura foi dividida em duas alíquotas e estas foram aplicadas uniformemente sob duas placas de IM-ágar (seção 4.2). O Co-cultivo foi realizado a $19^{\circ} \mathrm{C}$ por 24 horas.

Após o co-cultivo, a superfície das placas foi raspada com o auxílio de uma lâmina de vidro estéril, e todo o conteúdo foi transferido para placas de PYG (seção 4.2) contendo $200 \mu \mathrm{g} \cdot \mathrm{mL}^{-1}$ do antibiótico cefotaxime (Sigma) para matar A. tumefasciens, e $150 \mu \mathrm{g} \cdot \mathrm{mL}^{-1}$ de higromicina B para selecionar transformantes resistentes de B. emersonii. As placas foram incubadas a $28^{\circ} \mathrm{C}$ até ocorrer esporulação e os zoósporos resistentes foram mantidos e selecionados 7 vezes em placas PYG contendo $250 \mu \mathrm{g} \cdot \mathrm{mL}^{-1}$ de higromicina B. Como controle negativo utilizamos o vetor binário pBINPLUS sem a inserção do cassete de resistência contendo Hph. A Figura 9, a seguir, ilustra o esquema geral do protocolo de transformação de B. emersonii. 


\section{Cultivar A. tumefasciens a \\ $28^{\circ} \mathrm{C} / 16 \mathrm{~h}$ em MM

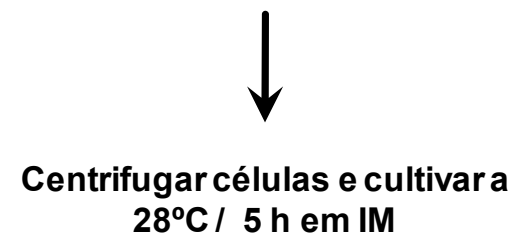

$\downarrow$

Coletar células por

centrifugação

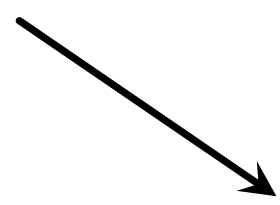

Misturar células e co-cultivar em IM-ágar a $19^{\circ} \mathrm{C} / 24 \mathrm{~h}$

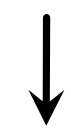

Coletar células por raspagem das placas e transferir para placas de PYG contendo cefotaxime para matar $A$. tumefasciens e higromicina B para selecionar transformantes de B. emersonii

Figura 9: Esquema do protocolo de transformação de $B$. emersonii mediada por $A$. tumefasciens.

\subsubsection{Extração rápida de DNA genômico de zoósporos}

Os zoósporos resistentes foram coletados das placas de PYG com 1,5 mL de água milliQ e foram centrifugados em tubo eppendorf a $12000 \mathrm{~g}$ por 5 minutos a $25^{\circ} \mathrm{C}$. Após duas lavagens com $1 \mathrm{~mL}$ de água milliQ foram adicionados $700 \mu \mathrm{L}$ de tampão de lise (Tris-Cl 50 mM, EDTA 10 mM, SDS 1\%, pH 7.5), seguido de inversão leve por 30 minutos a $25^{\circ} \mathrm{C}$. Em seguida foram feitas extrações sucessivas com fenol saturado $\mathrm{pH} 7.5$, fenol saturado $\mathrm{pH}$ 7,5/clorofórmio $(1 / 1 ; \mathrm{v} / \mathrm{v})$ e clorofórmio puro. O DNA genômico foi precipitado adicionando-se acetato de sódio $3 \mathrm{M}$ na proporção $1 / 10(\mathrm{v} / \mathrm{v})$ e isopropanol gelado na 
proporção $1 / 1(\mathrm{v} / \mathrm{v})$. Após a $12000 \mathrm{~g}$ por 20 minutes a $4^{\circ} \mathrm{C}$ o DNA foi lavado com etanol $70 \%$ gelado e seco em SpeedVac. O DNA precipitado e seco foi então dissolvido em $50 \mu \mathrm{L}$ de TE/RNAse (Tris-HCl $10 \mathrm{mM}$, EDTA $1 \mathrm{mM}$, RNAse A $20 \mu \mathrm{g} \cdot \mathrm{mL}^{-1}, \mathrm{pH}$ 8.0) e guardado a $20^{\circ} \mathrm{C}$. 


\section{RESULTADOS E DISCUSSÃO}

\subsection{Carência de oxigênio: Hipóxia Gradual e Direta}

\subsubsection{Aspectos morfológicos}

Como pode ser observado na Figura 10, as células de $B$. emersonii adquirem uma forma alongada anormal quando a concentração de oxigênio dissolvido é diminuída nos experimentos de hipóxia gradual. Apesar deste alongamento, as células crescem volumetricamente mesmo durante hipóxia e, após a reoxigenação, elas parecem começar a recuperar a forma ovalada normal. Como um teste de viabilidade celular a cultura foi incubada a $19^{\circ} \mathrm{C}$ em normóxia, por mais $12 \mathrm{~h}$ após o término do experimento de hipóxia gradual. Foi observado que a grande maioria das células recuperou a morfologia e crescimento normal e também pôde ser observada a formação e liberação de zoósporos, indicando que as células permanecem viáveis e funcionais. 


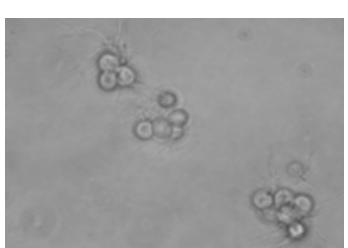

A

$70 \%$ sat $\mathrm{O}_{2}$

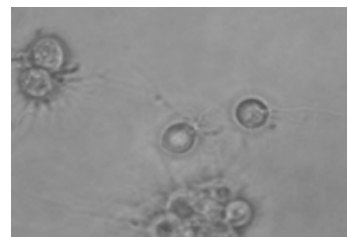

B

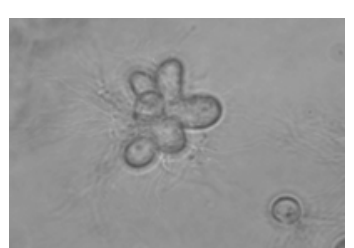

C

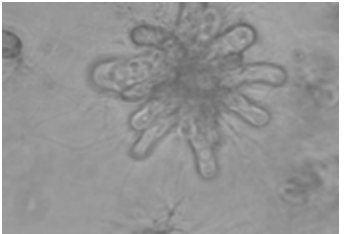

D $35 \%$ sat $\mathrm{O}_{2}$ $17,5 \%$ sat $\mathrm{O}_{2}$ $5 \%$ sat $\mathrm{O}_{2}$

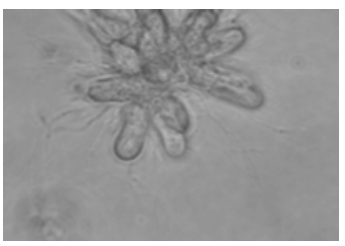

$\underset{1 \% \text { sat } O_{2}}{E}$

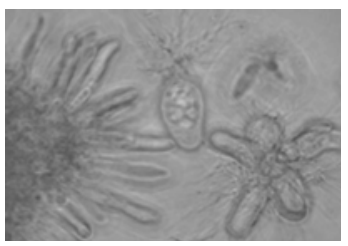

$\underset{\% \text { sat } \mathrm{O}_{2}}{\mathrm{~F}}$

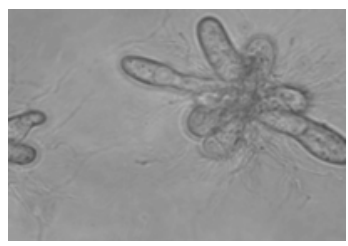

G

reox $70 \%$ sat $\mathrm{O}_{2}$

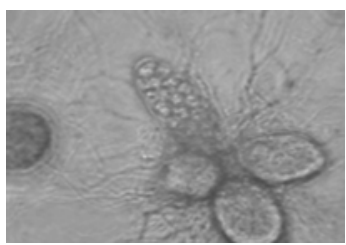

$\mathrm{H}$

$+12 \mathrm{~h} / 19^{\circ} \mathrm{C} 70 \%$ sat $\mathrm{O}_{2}$

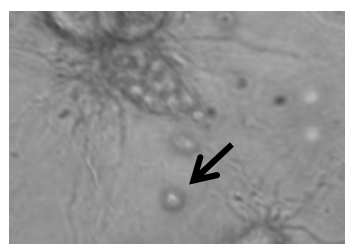

I

$+12 \mathrm{~h} / 19^{\circ} \mathrm{C} 70 \%$ sat $\mathrm{O}_{2}$

Figura 10: Alterações morfológicas em células de $B$. emersonii submetidas à hipóxia gradual. As amostras para microscopia óptica foram retiradas em cada etapa do experimento de hipóxia gradual (ver seta e pontas de seta na Figura 4 pag. 26). As células crescem normalmente em normóxia (A) e 35\% sat. $\mathrm{O}_{2}$ (B), mas começam a adquirir uma forma alongada anormal à medida que a concentração de oxigênio dissolvido é diminuída. $(\mathbf{C}, \mathbf{D}, \mathbf{E}$ e F). Após reoxigenação $(\mathbf{G})$, as células parecem começar a recuperar a forma ovalada normal. Como teste de viabilidade celular a cultura foi incubada a $19^{\circ} \mathrm{C}$ em normóxia, por mais $12 \mathrm{~h}$ após o término do experimento de hipóxia gradual. A grande maioria das células recuperou a morfologia e crescimento normal (H e I) e também pôde ser observada a formação e liberação de zoósporos (seta em I).

\subsubsection{Captação de glicose}

Foram realizadas medidas de concentração de glicose no meio extracelular (seção 4.7) dos experimentos de hipóxia gradual. Como pode ser observado na Figura 11, a captação de glicose do meio aumenta ligeiramente nas primeiras $6.5 \mathrm{~h}$ de normóxia, mas passa a crescer consideravelmente conforme o oxigênio é diminuído e cresce ainda mais 
rapidamente quando as células são reoxigenadas. Este resultado corrobora o perfil transcricional de indução que foi observado para a maioria dos genes de via glicolítica e para o transportador de hexose HXT-14 (seção 5.1.7). Durante a reoxigenação, a captação de glicose aumentou mais rapidamente provavelmente porque altos níveis de enzimas glicolíticas estavam presentes devido à regulação transcricional. Assim, quando o oxigênio se tornou livremente disponível, a fosforilação oxidativa e o ciclo de Krebs puderam funcionar mais rapidamente, oxidando os carbonos provenientes da via glicolítica.

Não se pode negar que o aumento da captação de glicose também pode ser um efeito do crescimento celular durante o experimento. Entretanto, fica claro que a taxa de aumento da captação, representada pela inflexão da curva média na Figura 11, muda consideravelmente quando se inicia a diminuição da concentração de oxigênio dissolvido (após $6.5 \mathrm{~h}$ de cultivo). Isto significa que a carência de oxigênio exerce influencia sobre a captação de glicose em $B$. emersonii, provavelmente devido às alterações metabólicas promovidas pela regulação transcricional. 


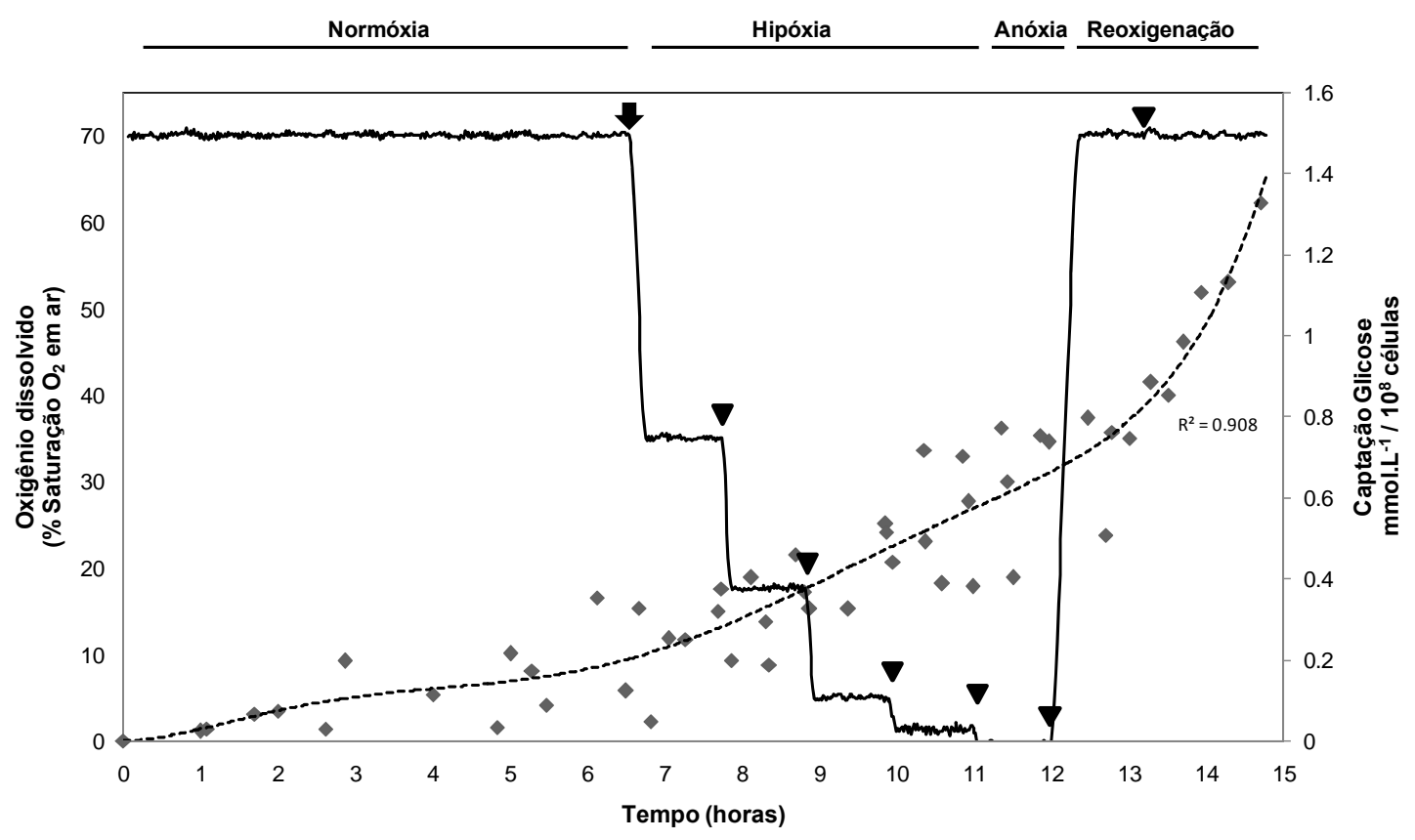

Figura 11: Efeito da disponibilidade de oxigênio na captação de glicose em hipóxia gradual. A captação de glicose do meio aumentou levemente durante as primeiras 6.5 horas de cultivo em normóxia, mas aumentou consideravelmente durante a carência de oxigênio e ainda mais rapidamente durante a reoxigenação. As quantificações foram realizadas em três experimentos independentes.

\subsubsection{Genes diferencialmente expressos}

No experimento de hipóxia gradual (seção 4.6) nós comparamos as populações de transcritos de células na condição controle (C70) com células nas demais concentrações de oxigênio (C35, C17.5, C5, C1, C0 e C70r). Dentre os 3773 ESTs analisados, 3169 (84.0\%) se mostraram expressos nos microarranjos e 366 (9.7\%) foram classificados como diferencialmente expressos em hipóxia, anóxia e reoxigenação.

Como no experimento de hipóxia gradual a concentração de oxigênio é diminuída gradativamente, as células podem ter sofrido um efeito de aclimatação, no que diz respeito à regulação da expressão gênica. Por esta razão, decidimos realizar o experimento de hipóxia direta (seção 4.8), no qual a concentração de oxigênio é diminuída diretamente de normóxia 
$\left(70 \%\right.$ sat. $\left.\mathrm{O}_{2}\right)$ para hipóxia $\left(1 \%\right.$ sat. $\left.\mathrm{O}_{2}\right)$ e 5 horas após restauração da normóxia. Neste experimento, dentre os 3773 ESTs analisados, 3379 (88.0\%) se mostraram expressos nos microarranjos e 456 (12.1\%) foram classificados como diferencialmente expressos em hipóxia e reoxigenação.

De fato, o experimento de hipóxia direta enriqueceu os dados de hipóxia gradual com 284 novos genes diferencialmente expressos, além dos 172 genes sobrepostos (Figura 12), totalizando 650 genes diferencialmente expressos em ambos os experimentos Tabela $\mathbf{S} \mathbf{1}$.

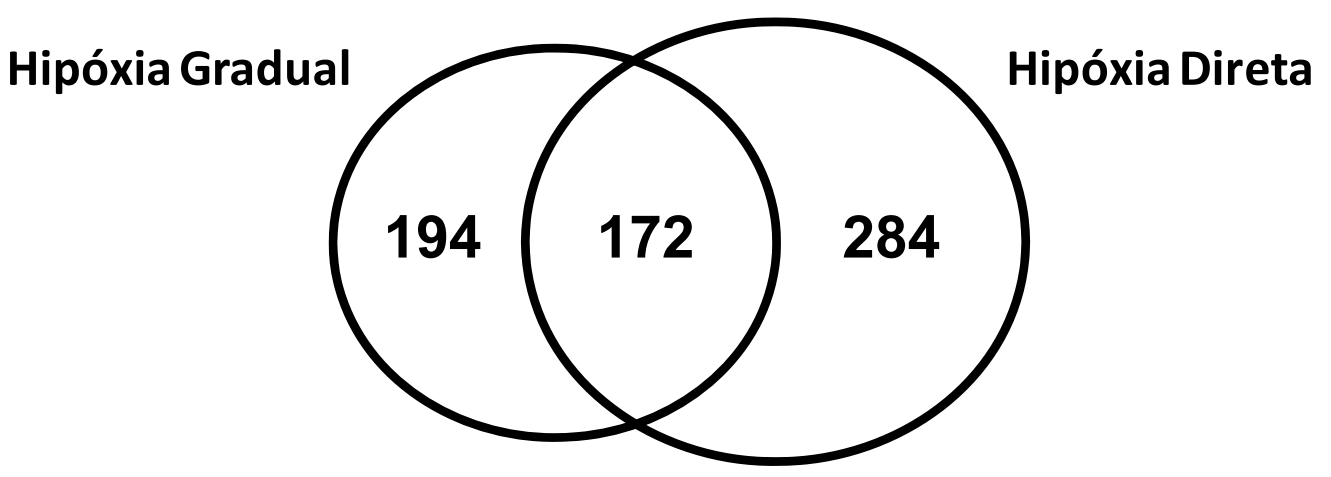

Figura 12: Genes diferencialmente expressos em Hipóxia Gradual e Hipóxia Direta. A superposição dos círculos mostra o número de genes comuns aos dois processos.

\subsubsection{Agrupamento dos genes diferencialmente expressos segundo os perfis de expressão}

A fim de se obter uma visão geral do perfil de expressão dos genes diferencialmente expressos em hipóxia gradual e direta, procedeu-se o seu agrupamento segundo o algoritmo K-means (seção 4.12.6). Foram obtidos 8 agrupamentos para cada experimento (Figura 13). 
A

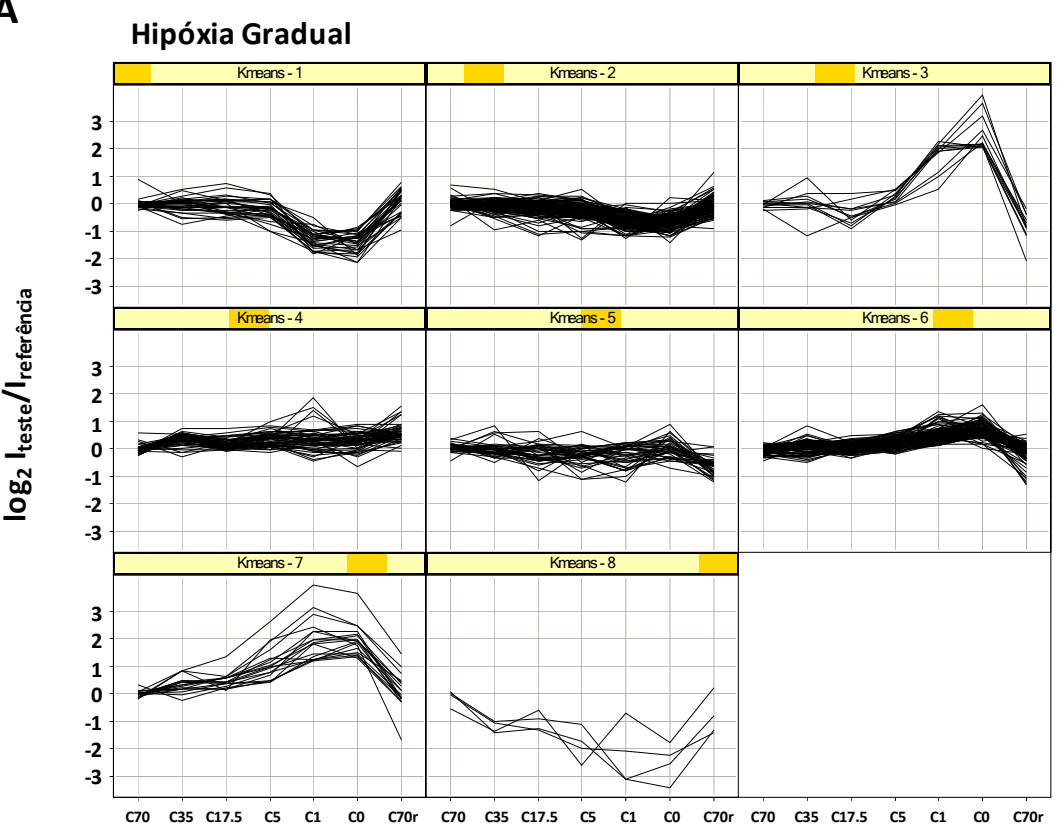

Condição de $\mathrm{O}_{2}$ dissolvido

B

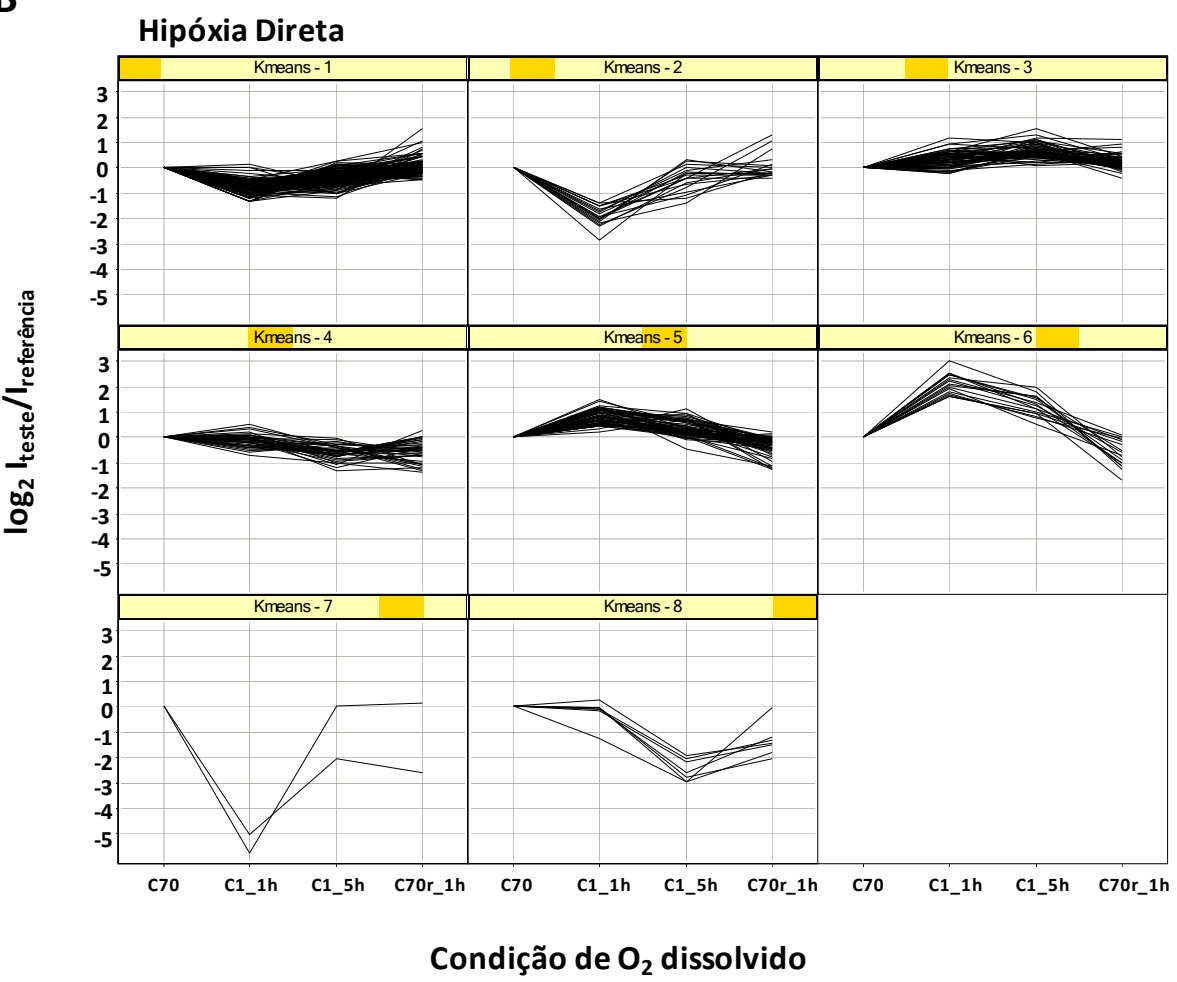

Figura 13: Agrupamento dos genes diferencialmente expressos em Hipóxia Gradual (A) e Hipóxia Direta (B). As abscissas indicam as condições de oxigênio dissolvido nos experimentos e as ordenadas indicam o $\log _{2}$ da razão de expressão da condição teste sobre a referência (C70). 
Estes agrupamentos permitiram a identificação e separação dos genes realmente afetados pela concentração de oxigênio dissolvido, e não por outros fatores como crescimento celular e modificações nutricionais durante o experimento. Para isso, levamos em consideração somente os genes que apresentaram um perfil de indução ou repressão durante a carência de oxigênio, seguido de recuperação da expressão (ou tendência à recuperação) aos níveis normais, quando as células foram reoxigenadas.

Desta maneira, dos 650 genes diferencialmente expressos em ambos os experimentos, 534 foram considerados afetados (direta ou indiretamente) pela concentração de oxigênio dissolvido, devido aos seus perfis de expressão. Ao todo 116 genes foram então desconsiderados por não apresentarem perfis de expressão marcante, no que diz respeito à hipóxia e reoxigenação. Todos os 650 genes diferencialmente expressos podem ser consultados no Material Suplementar (Tabela S 1).

\subsubsection{Determinação das categorias do Consórcio Gene Ontology (GO) mais} representadas entre os genes diferencialmente expressos em hipóxia

$$
\text { Realizamos uma análise utilizando o aplicativo BayGO }
$$

(http://blasto.iq.usp.br/ tkoide/BayGO) (Vencio et al., 2006), para determinar de maneira estatisticamente confiável as categorias do Consórcio Gene Ontology (GO) mais representadas entre os genes com perfis induzidos ou reprimidos em hipóxia gradual e/ou direta (Tabela 2). 
Tabela 2: Categorias do Gene Ontology (GO) mais representadas entre os genes com perfis induzidos e reprimidos em hipóxia gradual e direta. As categorias são classificadas em três grupos: Função molecular (m), Processo biológico (b) e Componente celular (c). As categorias foram consideradas altamente representadas quando possuíam valor da probabilidade $\mathrm{P}$ menor ou igual a 0.05 .

\begin{tabular}{crl}
\hline $\begin{array}{c}\text { Induzidos } \\
\text { P }\end{array}$ & \multicolumn{1}{c}{ ID } & Descrição \\
\hline 0 & GO:0005975 & (b)carbohydrate metabolism \\
0.01 & GO:0016868 & (m)intramolecular transferase activity, phosphotransferases \\
0.01 & GO:0015976 & (b)carbon utilization \\
0.03 & GO:0004733 & (b)pyridoxine biosynthesis \\
0.03 & GO:0004034 & (m)aldose 1-epimerase activity \\
0.03 & GO:0006807 & (b)nitrogen compound metabolism \\
0.04 & GO:0005198 & (m)structural molecule activity \\
0.04 & GO:0008061 & (m)chitin binding \\
0.04 & GO:0046872 & (m)metal ion binding \\
0.04 & GO:0000724 & (b)double-strand break repair via homologous recombination \\
0.04 & GO:0031966 & (c)mitochondrial membrane \\
0.04 & GO:0004301 & (m)epoxide hydrolase activity \\
0.05 & GO:0009116 & (b)nucleoside metabolism \\
0.05 & GO:0006096 & (b)glycolysis \\
0.05 & GO:0006032 & (b)chitin catabolism \\
& & \\
\hline Reprimidos & & \\
P & ID & Descrição \\
\hline 0 & GO:0006457 & (b)protein folding \\
0.01 & GO:0051082 & (m)unfolded protein binding \\
0.02 & GO:0005739 & (c)mitochondrion \\
0.02 & GO:0006520 & (b)amino acid metabolism \\
0.02 & GO:0006626 & (b)protein targeting to mitochondrion \\
0.03 & GO:0005515 & (m)protein binding \\
0.03 & GO:0004300 & (m)enoyl-CoA hydratase activity \\
0.04 & GO:0006857 & (b)oligopeptide transport \\
0.05 & GO:0005524 & (m)ATP binding \\
0.05 & GO:0004070 & (m)aspartate carbamoyltransferase activity \\
\hline & &
\end{tabular}

A análise utilizando BayGO identifica categorias funcionais estatisticamente bem representadas num grupo de genes diferencialmente expressos, em relação ao universo de 
genes em estudo. Deste modo, podemos inferir com mais confiabilidade que tais categorias são realmente importantes para a resposta celular ao estresse em questão.

Com base neste raciocínio, pudemos observar que as categorias mais importantes entre os genes com perfis induzidos estão relacionadas a: metabolismo de carboidratos (carbohydrate metabolism; glycolysis; carbon utilization), metabolismo de quitina (chitin catabolism; chitin binding), estrutura celular (structural molecule activity), homeostase redox (pyridoxine biosynthesis) e metabolismo de ácidos nucléicos (nucleoside metabolism). Dentre os genes com perfis reprimidos, as categorias mais relevantes estão principalmente relacionadas a: processos dispendiosos em energia, como enovelamento de proteínas (protein folding; unfolded protein binding), metabolismo de aminoácidos (amino acid metabolism), transporte por membrana (oligopeptide transport; protein targeting to mitochondrion), além de processos moleculares dependentes de ligação a ATP (ATP binding).

\subsubsection{Análise da expressão de genes ausentes nos microarranjos por $q R T-P C R$}

Decidimos avaliar por qRT-PCR a expressão de alguns genes de interesse no experimento de hipóxia gradual., que não estavam depositados nos microarranjos. As sequências dos oligonucleotídeos utilizados estão na Tabela 1 (seção 4.13). Como normalizador, foi utilizado o gene BeE60H30A07, que codifica uma "heat shock protein 90 kDa”, não afetado por hipóxia gradual nos microarranjos.

Os genes analisados codificam enzimas que fazem parte da via glicolítica de B. emersonii e, como podemos observar na Figura 14, todos eles foram significativamente induzidos em condições de hipóxia. 

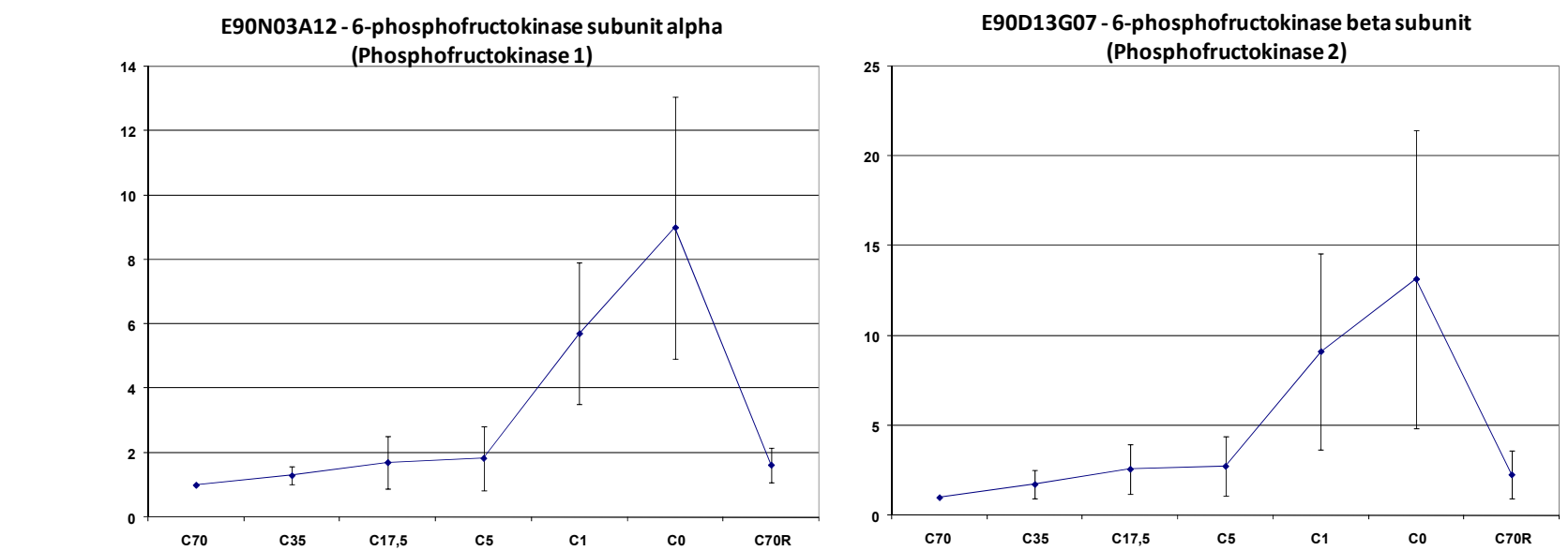

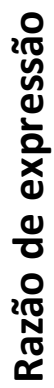
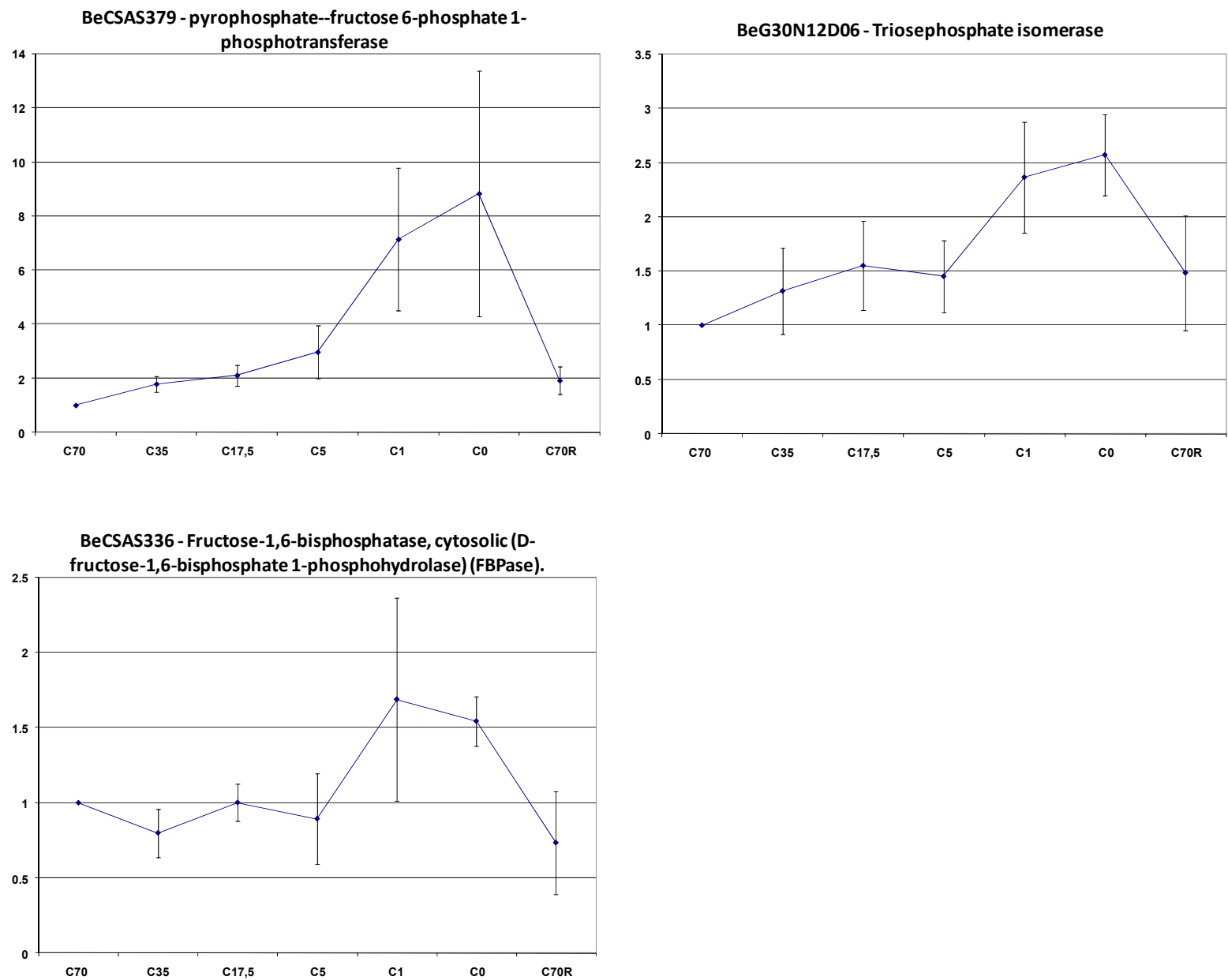

\section{Condição de $\mathrm{O}_{2}$ dissolvido}

Figura 14: Análise da expressão por qRT-PCR de genes ausentes nos microarranjos de cDNA. Na ordenada estão mostradas as razões de expressão e na abscissa as condições de oxigênio dissolvido. As barras verticais representam os desvios-padrão das análises realizadas em duplicata biológica. 


\subsubsection{Análise dos genes afetados pela concentração de oxigênio dissolvido}

Por razões práticas, os 534 genes afetados por hipóxia foram classificados de acordo com o comportamento de indução ou repressão quando a concentração de oxigênio diminui. Deste modo, 220 foram considerados induzidos e 314 reprimidos, pela carência de oxigênio. A Figura 15, a seguir, ilustra a distribuição destes 534 genes classificados manualmente em categorias funcionais.

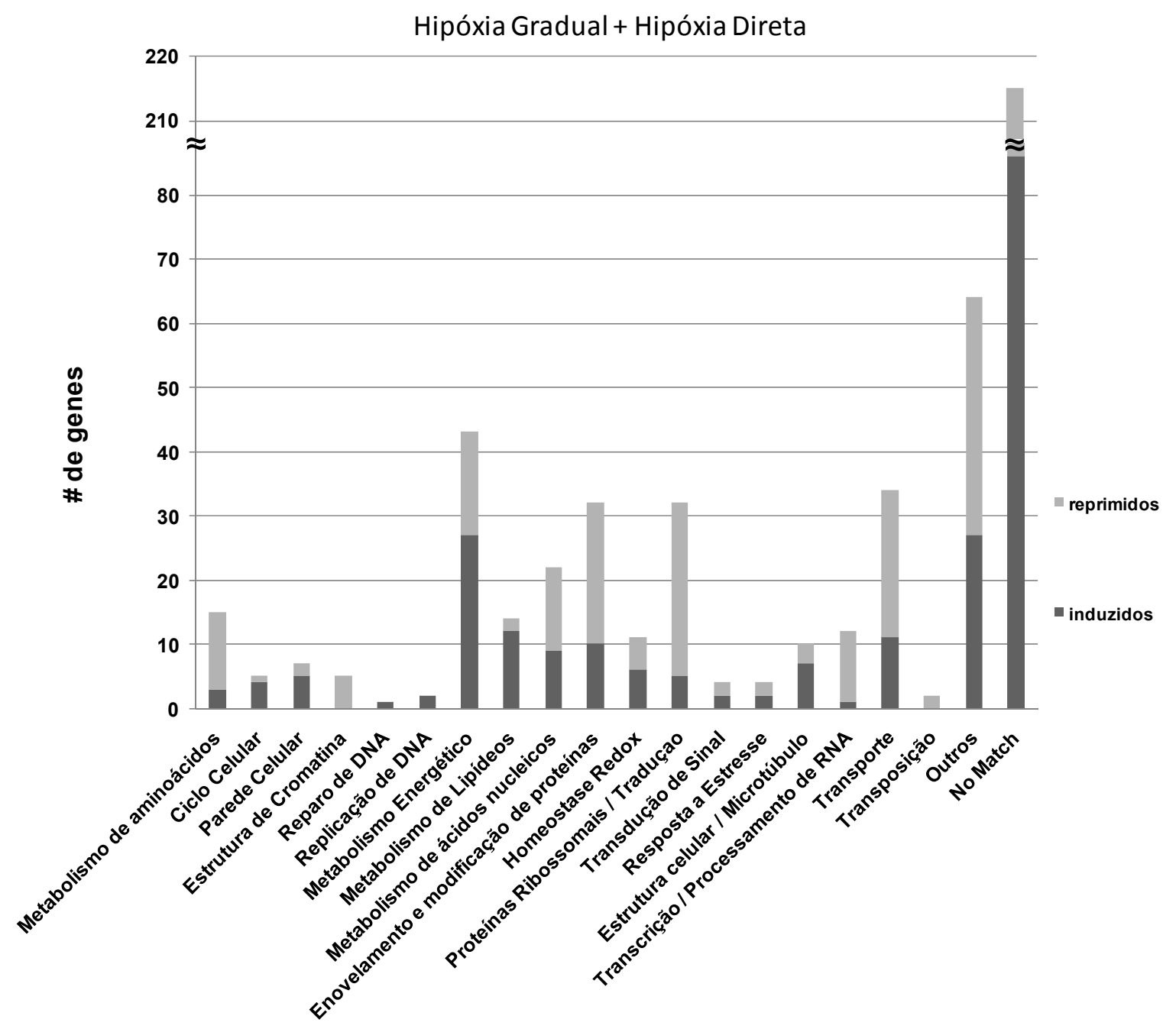

Figura 15: Genes com perfis induzidos ou reprimidos em hipóxia gradual e/ou direta, distribuídos em categorias funcionais de acordo com o GO. 
Podemos notar na Figura 15 que certos processos biológicos merecem destaque, pois exibem certa predominância de genes com perfis induzidos ou reprimidos em carência de oxigênio. Processos como metabolismo de aminoácidos, enovelamento e modificação de proteínas, estrutura de cromatina, transporte, proteínas ribossômicas/tradução e transcrição/processamento de RNA apresentaram maior porcentagem de genes com perfil reprimido, sugerindo que tais processos devem estar inibidos quando há privação de oxigênio. Em contraste, processos como ciclo celular, parede celular, metabolismo energético, metabolismo de lipídeos e estrutura celular/microtúbulos apresentaram a maior parte de seus genes com perfil induzido.

A Tabela 3, a seguir, mostra os genes afetados por hipóxia gradual e/ou direta, que apresentam alguma similaridade com sequências depositadas no GenBank e/ou SwissProt. A lista completa, contendo os No Matches e proteínas hipotéticas sem função conhecida, assim como os genes sem perfis de expressão marcantes, pode ser consultada no Material Suplementar (Tabela S 1).

Tabela 3: Lista de genes afetados por hipóxia gradual e/ou direta obtidos pela técnica de microarranjo de cDNA. Os valores representam a razão de expressão (teste/C70). As setas indicam os perfis de indução (para cima) ou repressão (para baixo).

\begin{tabular}{|c|c|c|c|c|c|c|c|c|c|c|c|c|c|c|c|}
\hline \multirow[b]{2}{*}{ Clone ID } & \multirow[b]{2}{*}{ SwissProt } & \multirow[b]{2}{*}{ Anotação } & \multirow[b]{2}{*}{$\begin{array}{l}\overline{0} \\
\overline{0} \\
\frac{1}{0} \\
\frac{1}{0}\end{array}$} & \multicolumn{4}{|c|}{ Hipóxia Direta } & \multicolumn{8}{|c|}{ Hipóxia Gradual } \\
\hline & & & & $\begin{array}{l}\text { न } \\
\text { J }^{\prime}\end{array}$ & $\begin{array}{l}\text { 돈 } \\
\text { 건 }\end{array}$ & 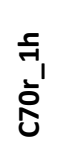 & 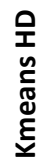 & $\stackrel{\circ}{0}$ & 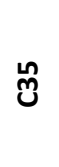 & 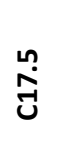 & บ & 거 & 웅 & 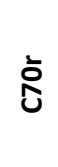 & 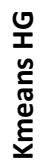 \\
\hline \multicolumn{16}{|c|}{ Metabolismo de Aminoácidos } \\
\hline BeZSPN04C10 & Q9P7L5 & ornithine-oxo-acid transaminase, putative & $\downarrow$ & 0.7 & 0.6 & 1.2 & 1 & & & & & & & & \\
\hline BeE120N30H05 & Q7RV8 & Arginase & $\downarrow$ & 0.5 & 0.9 & 1.1 & 1 & 1.1 & 1.1 & 0.8 & 0.6 & 0.4 & 0.4 & 1.1 & 1 \\
\hline BeE30N08H12 & P9497 & 2-isopropylmalate synthase & $\downarrow$ & 0.8 & 0.9 & 1.4 & 1 & 1.0 & 1.2 & 1.0 & 1.0 & 0.7 & 0.7 & 1.2 & 2 \\
\hline BeE30N15B02 & & cysteine synthase & $\downarrow$ & 0.8 & 0.7 & 1.1 & 1 & & 0.9 & 1.1 & 1.1 & & 0.5 & 0.7 & 2 \\
\hline BeE30N19D09 & Q7VVU3 & $\begin{array}{l}\text { 5-methyltetrahydropteroyltriglutamate-- } \\
\text { homocysteine methyltransferase }\end{array}$ & $\downarrow$ & 0.2 & 0.6 & 2.1 & 2 & 1.0 & 0.4 & 0.4 & 0.3 & 0.1 & 0.1 & 0.4 & 8 \\
\hline BeE60H28B12 & Q96VZ6 & Acetolactate synthase Ilv2 & $\downarrow$ & 0.4 & 0.5 & 2.9 & 1 & 1.0 & 1.2 & 1.5 & 1.3 & 0.3 & 0.3 & 1.5 & 1 \\
\hline BeE60N07B05 & Q9NAE2 & Probable urocanate hydratase & $\downarrow$ & 0.6 & 0.8 & 0.9 & 1 & 1.1 & 1.1 & 1.0 & 0.9 & 0.6 & 0.8 & 0.9 & 2 \\
\hline BeE90D12G12 & P48611 & 6-pyruvoyl tetrahydropterin synthase & $\downarrow$ & 1.0 & 0.7 & 1.4 & 1 & 1.0 & 1.1 & 0.9 & 0.8 & 0.6 & 1.3 & 0.6 & 5 \\
\hline
\end{tabular}




\begin{tabular}{|c|c|c|c|c|c|c|c|c|c|c|c|c|c|c|c|}
\hline BeG120N15B05 & Q12642 & S-adenosylmethionine synthetase (Fragment) & $\downarrow$ & 0.3 & & & & 1.0 & 0.5 & 0.5 & 0.5 & 0.1 & 0.2 & 0.6 & 8 \\
\hline BeZSPN16H02 & P1869 & Aspartokinase & $\downarrow$ & 0.6 & 0.9 & 1.2 & 1 & 0.9 & 0.9 & 1.0 & 0.9 & 0.5 & 0.5 & 1.4 & 1 \\
\hline BeG30N04E01 & Q8JHX9 & Glutamate dehydrogenase 3 & $\downarrow$ & & & & & 1.2 & 0.8 & & 0.5 & & 0.6 & 0.8 & 2 \\
\hline BeZSPN14H05 & & histidinol phosphate aminotransferase & $\downarrow$ & 0.7 & 1.0 & 1.4 & 1 & 1.0 & 0.7 & 0.7 & 0.7 & 0.3 & 0.2 & 0.7 & 1 \\
\hline BeE60C11F11 & P22768 & Argininosuccinate synthase & $\uparrow$ & 0.9 & 1.6 & 1.1 & 3 & 1.0 & 1.8 & 1.2 & 1.2 & 1.6 & 1.7 & 0.4 & 6 \\
\hline BeG90N02C03 & P78568 & Delta-1-pyrroline-5-carboxylate dehydrogenase & $\uparrow$ & 1.7 & 2.1 & 1.2 & 3 & 1.1 & 1.1 & 0.9 & 1.0 & 1.7 & 2.1 & 1.0 & 6 \\
\hline \multirow[t]{2}{*}{ BeG90N10B05 } & Q8KCK4 & Glutamine synthetase & $\uparrow$ & 1.2 & 1.7 & 1.3 & 3 & 1.0 & 1.1 & 0.9 & 1.2 & 1.3 & 1.9 & 1.0 & 6 \\
\hline & & Ciclo Celular & & & & & & & & & & & & & \\
\hline BeG30N12D04 & Q2533 & Cyclin-dependent kinases regulatory subunit & $\downarrow$ & 0.7 & 0.9 & 1.1 & 1 & & & & & & & & \\
\hline BeE120N32A08 & P7862 & Septin B & $\uparrow$ & 1.0 & 1.8 & 1.2 & 3 & 0.9 & 1.4 & 1.0 & 1.1 & 1.1 & 1.4 & 0.8 & 6 \\
\hline BeE60N18D05 & & cyclin-dependent protein kinase $\mathrm{PHOB}$ & $\uparrow$ & & & & & 1.1 & 1.1 & 0.9 & 1.1 & 1.4 & 1.6 & 1.1 & 6 \\
\hline BeG30N08C06 & Q9C1M3 & Septin & $\uparrow$ & & & & & 1.0 & 1.1 & 1.0 & 0.9 & 1.2 & 1.7 & 1.0 & 6 \\
\hline \multirow[t]{2}{*}{ BeZSPN15D07 } & P34991 & S-phase kinase-associated protein $1 \mathrm{~A}$ & $\uparrow$ & & & & & 1.0 & 1.0 & 1.0 & 1.2 & 1.5 & 1.4 & 1.0 & 6 \\
\hline & & Parede Celular & & & & & & & & & & & & & \\
\hline BeE60N10E05 & Q99447 & Ethanolamine-phosphate cytidylyltransferase & $\downarrow$ & & & & & 1.0 & 1.1 & 0.8 & 0.9 & 0.6 & 0.6 & 0.9 & 2 \\
\hline BeG90N10G04 & P87073 & Chitin synthase 1 & $\downarrow$ & & & & & 1.2 & 0.8 & 0.8 & 0.5 & 0.6 & 0.6 & 0.7 & 2 \\
\hline BeE90N16E04 & Q7X5L8 & Chitinase Chi80 precursor & $\uparrow$ & 1.3 & 1.5 & 1.0 & 3 & & & & & & & & \\
\hline BeG90N06B05 & Q96VN & Chitin deacetylase & $\uparrow$ & 1.4 & & 0.1 & & & & & & & & & \\
\hline BeZSPN18C06 & & $\begin{array}{l}\text { proteophosphoglycan } \\
\text { glucosamine--fructose-6-phosphate }\end{array}$ & $\uparrow$ & 1.2 & 1.3 & 1.0 & 3 & & & & & & & & \\
\hline BeE60N03F03 & & aminotransferase & $\uparrow$ & 1.8 & 1.2 & 0.8 & 5 & 1.0 & 1.1 & 1.1 & 1.2 & 1.5 & 2.1 & 1.0 & 6 \\
\hline \multirow[t]{2}{*}{ BeZSPN18H03 } & Q9SQF7 & Chitinase & $\uparrow$ & 1.4 & 1.3 & 1.1 & 3 & 1.0 & 1.2 & 1.1 & 1.2 & 1.3 & 1.5 & 1.2 & 6 \\
\hline & & Estrutura de Cromatina & & & & & & & & & & & & & \\
\hline BeG30N17G05 & Q1469 & programmed cell death 11 & $\downarrow$ & 0.9 & 0.7 & 0.9 & 4 & & & & & & & & \\
\hline BeE120N03F12 & Q9JM53 & Programmed cell death protein 8, mitochondr & $\downarrow$ & & & & & 1.0 & 0.9 & 0.8 & 0.8 & 0.7 & 0.7 & 0.8 & 2 \\
\hline BeE30N02C10 & Q9HDN1 & Histone H3 & $\downarrow$ & & & & & 1.0 & 1.0 & 1.0 & 0.9 & 0.8 & 0.7 & 1.0 & 2 \\
\hline BeE60H06B09 & Q07135 & Histone $\mathrm{H} 2 \mathrm{~A}$ & $\downarrow$ & & & & & 1.0 & 1.0 & 1.1 & 0.9 & 0.8 & 0.6 & 1.1 & 2 \\
\hline \multirow[t]{2}{*}{ BeNSVP07G09 } & Q8J1K2 & Histone H2B & $\downarrow$ & & & & & 0.8 & 1.0 & 1.0 & 0.9 & 0.7 & 0.5 & 1.1 & 2 \\
\hline & & Reparo de DNA & & & & & & & & & & & & & \\
\hline \multirow[t]{2}{*}{ BeE30N07D04 } & 013768 & Putative dna repair helicase & $\uparrow$ & 2.0 & 1.6 & 1.0 & 5 & & & & & & & & \\
\hline & & Replicação de DNA & & & & & & & & & & & & & \\
\hline BeE60H16G11 & & Origin recognition complex, subunit 5 (ISS) & $\uparrow$ & 4.3 & 3.0 & 0.5 & 6 & 0.9 & 0.9 & 0.9 & 1.0 & 3.9 & 12.6 & 0.8 & 3 \\
\hline \multirow[t]{2}{*}{ BeG120N03B10 } & Q8R323 & Replication factor $\mathrm{C}$ subunit 3 & $\uparrow$ & 3.5 & 2.0 & 1.0 & 6 & & & & 1.1 & 2.2 & 6.5 & & 3 \\
\hline & & Metabolismo Energético & & & & & & & & & & & & & \\
\hline BeE90N17C02-1 & Q83PF & deoxyribose-phosphate aldolase [Escherichia coli] & $\downarrow$ & 0.6 & & 0.7 & & & & & & & & & \\
\hline BeG120N19C09 & & $\begin{array}{l}\text { 6-phosphogluconolactonase [Laccaria bicolor } \\
\text { phosphoenolpyruvate carboxykinase [Emericella }\end{array}$ & $\downarrow$ & 0.5 & & 0.9 & & & & & & & & & \\
\hline BeNSVP12G02 & & nidu & $\downarrow$ & 0.7 & 0.9 & 1.0 & 1 & & & & & & & & \\
\hline BeZSPN09E08 & Q7Z8B6 & $\mathrm{H}(+)$-ATPase [Glomus mosseae] & $\downarrow$ & 1.0 & 0.6 & 0.6 & 4 & & & & & & & & \\
\hline BeE120N27B02 & P5625 & Cytochrome c & $\downarrow$ & 0.6 & 0.7 & 1.0 & 1 & 1.0 & 0.9 & 0.9 & 0.9 & 0.5 & 0.3 & 1.4 & 1 \\
\hline BeE30N04B04 & Q9UVH9 & $\begin{array}{l}\text { Fox } 2 \text { protein } \\
\text { ATP synthase epsilon chain domain containing }\end{array}$ & $\downarrow$ & 0.4 & 0.6 & 1.8 & 1 & 1.0 & 0.9 & 1.1 & 1.4 & 0.6 & 0.6 & 2.2 & 2 \\
\hline BeE60H29B11 & & protein & $\downarrow$ & 0.7 & 0.8 & 1.2 & 1 & 0.9 & 1.0 & 1.0 & 0.9 & 0.7 & 0.6 & 0.8 & 2 \\
\hline BeG30N08D01 & Q9Y3D8 & Adenylate kinase isoenzyme 6 & $\downarrow$ & 0.9 & 0.6 & 0.9 & 4 & 1.0 & 1.0 & 1.0 & 0.9 & 0.6 & 0.6 & 1.1 & 2 \\
\hline BeE120N27B03 & Q03015 & $\mathrm{NADH}$-ubiquinone oxidoreductase $12 \mathrm{kDa}$ subunit & $\downarrow$ & & & & & 1.1 & 0.8 & 0.9 & 0.9 & 0.8 & 0.7 & 1.0 & 2 \\
\hline BeE3ON04H06 & Q9Z2K9 & Isocitrate dehydrogenase [NADP] cytoplasmic & $\downarrow$ & & & & & 1.1 & 1.3 & 1.2 & 1.1 & 0.6 & 0.8 & 1.0 & 2 \\
\hline BeE30N05E04 & Q7Z940 & Succinyl-CoA synthetase, beta subunit & $\downarrow$ & & & & & 1.1 & 1.1 & 0.9 & 0.8 & 0.7 & 0.7 & 1.0 & 2 \\
\hline BeE60N08H02 & 013350 & ATP synthase D chain, mitochondrial & $\downarrow$ & & & & & 1.0 & 1.1 & 1.0 & 1.0 & 0.7 & 0.8 & 0.9 & 2 \\
\hline
\end{tabular}




\begin{tabular}{|c|c|c|c|c|c|c|c|c|c|c|c|c|c|c|c|}
\hline BeG120N03B06 & Q9UWEO & Dihydrolipoamide succinyltransferase & $\downarrow$ & & & & & 1.0 & 0.9 & 0.8 & 0.7 & 0.4 & 0.5 & 0.7 & 1 \\
\hline BeG120N07H08 & 074699 & Aconitase & $\downarrow$ & & & & & 1.0 & 0.9 & 0.8 & 0.9 & 1.0 & 0.8 & 1.4 & 2 \\
\hline BeG90N01G09 & Q7NJZ3 & Ribose 5-phosphate epimerase & $\downarrow$ & & & & & 0.8 & 0.7 & 0.8 & 0.8 & 0.6 & 0.4 & 0.8 & 2 \\
\hline BeG90N12C05 & & glutaryl-Coenzyme A dehydrogenase isoform a & $\downarrow$ & & & & & 1.0 & 1.0 & 0.9 & 0.7 & 0.6 & 0.4 & 0.9 & 2 \\
\hline BeE60H08E04 & Q9A212 & Quinone oxidoreductase & $\uparrow$ & 1.2 & 1.5 & 1.0 & 3 & & & & & & & & \\
\hline BeE60H17D05 & P53659 & Vacuolar ATP synthase subunit d & $\uparrow$ & 1.5 & 1.4 & 1.0 & 3 & & & & & & & & \\
\hline BeE60H32F11 & & aldose 1-epimerase, putative [Aspergillus clavatus & $\uparrow$ & 1.7 & 1.2 & 0.9 & 5 & & & & & & & & \\
\hline BeE60N02F01 & & UTP-glucose-1-phosphate uridylyltransferase & $\uparrow$ & 1.5 & 1.9 & 1.0 & 3 & & & & & & & & \\
\hline BeE60N17G05 & Q9YHT2 & succinate dehydrogenase complex, subunit B & $\uparrow$ & 2.1 & 1.6 & 0.9 & 5 & & & & & & & & \\
\hline BeE90N05B09 & Q8GUB3 & Putative vacuolar ATPase subunit $\mathrm{H}$ & $\uparrow$ & 1.6 & 1.4 & 1.2 & 3 & & & & & & & & \\
\hline BeG30N12E07 & Q9P8D2 & Cytochrome c oxidase subunit V & $\uparrow$ & 1.4 & 1.2 & 0.9 & 5 & & & & & & & & \\
\hline BeG60N14B08 & Q86AV6 & citrate synthase [Dictyostelium discoideum & $\uparrow$ & & 1.7 & 1.1 & & & & & & & & & \\
\hline BeG90N01D12 & P4157 & 6-phosphogluconate dehydrogenase & $\uparrow$ & 1.0 & 2.2 & 1.1 & 3 & & & & & & & & \\
\hline BeG90N05E08 & Q9171 & Pyruvate dehydrogenase E1 component beta su & $\uparrow$ & 1.2 & 1.4 & 1.0 & 3 & & & & & & & & \\
\hline BeE120N03E01 & Q8ZN3 & D-lactate dehydrogenase & $\uparrow$ & 5.0 & 4.0 & 0.6 & 6 & 1.0 & 1.0 & 0.5 & 1.2 & 4.8 & 4.2 & 0.4 & 3 \\
\hline BeE30N02H06 & Q9P4V2 & Phosphoacetylglucosamine mutase & $\uparrow$ & 2.3 & 1.6 & 0.9 & 5 & & 1.1 & 0.9 & 1.3 & 2.0 & 2.2 & 0.9 & 6 \\
\hline BeE30N15D01 & & NADP-dependent alcohol dehydrogenase & $\uparrow$ & 1.6 & 2.9 & 1.4 & 3 & 1.0 & 1.0 & 1.3 & 1.3 & 2.5 & 3.7 & 1.2 & 7 \\
\hline BeE30N21H07 & P6738 & Glycogen phosphorylase & $\uparrow$ & 1.3 & 2.0 & 1.0 & 3 & 1.1 & 1.1 & 0.9 & 1.2 & 1.4 & 1.7 & 0.7 & 6 \\
\hline BeE60H08B07 & 074478 & phosphoglucomutase & $\uparrow$ & 1.5 & 1.4 & 1.0 & 3 & 1.0 & 1.3 & 0.9 & 1.1 & 1.2 & 1.6 & 1.1 & 6 \\
\hline BeE60N02G08 & & aldose 1-epimerase, putative & $\uparrow$ & 3.1 & 1.8 & 0.8 & 6 & 1.1 & 1.2 & 1.2 & 1.3 & 2.4 & 2.4 & 0.7 & 6 \\
\hline BeE60N05D05 & Q8EBH2 & Transaldolase & $\uparrow$ & 1.5 & 1.5 & 1.0 & 3 & 1.1 & 1.0 & 1.0 & 1.2 & 1.6 & 3.1 & 0.8 & 6 \\
\hline BeE60N10B03 & & vacuolar ATP synthase subunit c & $\uparrow$ & 2.1 & 1.3 & 0.9 & 5 & 0.9 & 1.2 & 1.1 & 1.4 & 2.3 & 2.2 & 0.8 & 6 \\
\hline BeE90N15E12 & & glycogen phosphorylase & $\uparrow$ & 1.5 & & 1.2 & & 1.1 & 1.0 & 0.9 & 1.2 & 1.7 & 2.1 & 0.8 & 6 \\
\hline BeG120N01F06 & 057656 & Glycerol-3-phosphate dehydrogenase [NAD+] & $\uparrow$ & 1.2 & 1.5 & 0.9 & 3 & 1.1 & 1.1 & 1.0 & 0.9 & 1.2 & 1.7 & 0.8 & 6 \\
\hline BeG30N15D05 & Q8Y2Q8 & carbonic anhydrase protein & $\uparrow$ & 5.5 & 2.8 & 0.5 & 6 & & 1.8 & 1.1 & 3.9 & 5.4 & 3.4 & 0.3 & 7 \\
\hline BeG90N11A02 & Q9WD9 & Glyceraldehyde 3-phosphate dehydrogenase & $\uparrow$ & 1.9 & 2.4 & 1.2 & 3 & 1.0 & 1.4 & 1.3 & 2.0 & 2.3 & 2.6 & 0.9 & 7 \\
\hline BeG90N18E08 & Q8X97 & Probable ATP-citrate synthase subunit 1 & $\uparrow$ & 1.7 & 1.1 & 0.4 & 5 & 1.0 & 1.3 & 1.1 & 1.2 & 1.3 & 2.0 & 0.4 & 6 \\
\hline BeE120N26G05 & P31413 & Vacuolar ATP synthase 16 kDa proteolipid subunit & $\uparrow$ & & & & & 1.0 & 1.1 & 1.1 & 1.3 & 1.5 & 1.4 & 1.0 & 6 \\
\hline BeG120N06H01 & & similar to phosphoglucomutase 2 & $\uparrow$ & & & & & 1.0 & 1.3 & 0.9 & 1.1 & 1.3 & 1.6 & 1.1 & 6 \\
\hline BeG90N03E03 & P42894 & Enolase & $\uparrow$ & & & & & 1.0 & 1.2 & 1.1 & 1.4 & 1.6 & 1.9 & 0.7 & 6 \\
\hline BeG90N13C04 & & phosphoglucose isomerase & $\uparrow$ & & & & & & 1.1 & 1.2 & & 1.3 & 1.3 & & 6 \\
\hline \multicolumn{16}{|c|}{ Metabolismo de Lipídeos } \\
\hline BeE60C35H09 & Q8BH95 & Enoyl coenzyme A hydratase & $\downarrow$ & 0.8 & 0.6 & 0.6 & 4 & & & & & & & & \\
\hline BeG90N21B12 & & Enoyl-CoA hydratase (31.2 kD) [Caenorhabditis eleg & $\downarrow$ & 0.9 & 0.5 & 0.6 & 4 & & & & & & & & \\
\hline BeE30N02B11 & & fatty acid-2 hydroxylase [Laccaria bicolor & $\uparrow$ & 2.2 & 1.1 & 0.9 & 5 & & & & & & & & \\
\hline BeE60C25C06 & Q88LT3 & 1-acyl-sn-glycerol-3-phosphate acyltransferase & $\uparrow$ & & 1.1 & 0.3 & & & & & & & & & \\
\hline BeE60N03A03 & & C-5 sterol desaturase & $\uparrow$ & 1.7 & & & & & & & & & & & \\
\hline BeG90N07B07 & & leukotriene A4 hydrolase & $\uparrow$ & 1.6 & 1.1 & 0.7 & 5 & & & & & & & & \\
\hline BeE120N30F01 & P5345 & C-4 methyl sterol oxidase & $\uparrow$ & 1.6 & 1.2 & 0.8 & 5 & 1.1 & 1.0 & 1.1 & 1.3 & 1.5 & 1.4 & 0.9 & 6 \\
\hline BeE60H26A05 & Q872A4 & Related to phosphatidylserine decarboxylase & $\uparrow$ & 5.0 & 2.6 & 1.0 & 6 & 0.9 & 1.8 & 2.5 & 6.1 & 15.8 & 12.6 & 2.7 & 7 \\
\hline BeG120N16E05 & P4398 & Fatty acid synthase subunit alpha & $\uparrow$ & 1.5 & 1.7 & 0.4 & 5 & 1.0 & 1.3 & 1.1 & 1.1 & 1.8 & 2.0 & 0.5 & 6 \\
\hline BeG60N06G05 & P7978 & $\begin{array}{l}\text { Delta-9 fatty acid desaturase } \\
\text { Deoxyhypusine hydroxylase (Deoxyhypusine }\end{array}$ & $\uparrow$ & 3.1 & 1.9 & 0.3 & 6 & 1.0 & 1.9 & 0.7 & 1.4 & 3.8 & 4.4 & 0.2 & 3 \\
\hline BeE60C08F07 & & monooxygenase) & $\uparrow$ & & & & & 0.9 & & 1.0 & 1.1 & 1.1 & 1.4 & 1.2 & 6 \\
\hline BeE60N03G10 & & cyclopropane-fatty-acyl-phospholipid synthase & $\uparrow$ & & & & & 1.1 & 1.8 & 1.5 & 3.8 & 8.9 & 5.7 & 2.0 & 7 \\
\hline BeZSPN13B04 & & 1-acylglycerol-3-phosphate acyltransferase (AtaAp) & $\uparrow$ & & & & & 0.9 & 0.8 & 1.1 & 1.0 & 1.2 & 1.5 & 0.9 & 6 \\
\hline BeE30N04A05 & & delta 4-(E)-sphingolipid desaturase & $\uparrow$ & & & & & 1.1 & 1.0 & 0.8 & 0.8 & 1.1 & 1.9 & 0.5 & 5 \\
\hline
\end{tabular}




\begin{tabular}{|c|c|c|c|c|c|c|c|c|c|c|c|c|c|c|c|}
\hline & & Metabolismo de Ácidos Nucleicos & & & & & & & & & & & & & \\
\hline BeE30N17G08 & Q7ZV49 & hypoxanthine phosphoribosyltransferase I & $\downarrow$ & 1.0 & 0.5 & 1.5 & 1 & & & & & & & & \\
\hline BeE30N18D07 & & ATP phosphoribosyltransferase & $\downarrow$ & 0.7 & 0.9 & 1.1 & 1 & & & & & & & & \\
\hline BeG60N16H02 & Q9BLT3 & Nucleoside hydrolase & $\downarrow$ & 0.6 & 0.5 & 0.9 & 1 & & & & & & & & \\
\hline BeG90N09B12 & Q27124 & ribonuleotide reductase small subunit & $\downarrow$ & 0.7 & 0.7 & 1.0 & 1 & & & & & & & & \\
\hline BeG90N12C08 & & similar to Endonuclease G like 1 (Endo G like) & $\downarrow$ & 0.5 & & & & & & & & & & & \\
\hline BeG30N12D07 & 093937 & PyrABCN & $\downarrow$ & 0.7 & 1.2 & 2.0 & 1 & 1.0 & 0.7 & 0.4 & 0.7 & 0.6 & 0.8 & 0.9 & 2 \\
\hline BeG30N15B12 & & URA1 protein & $\downarrow$ & 0.9 & 1.5 & 1.9 & 3 & 1.0 & 0.8 & 0.7 & 0.8 & 0.7 & 0.9 & 1.0 & 2 \\
\hline BeG30N20G08 & Q8NIH8 & Nuclease Le3 & $\downarrow$ & 1.1 & 0.6 & 0.7 & 4 & 1.1 & 0.9 & 1.0 & 0.6 & 0.9 & 0.6 & 0.5 & 5 \\
\hline BeG60N19B01 & P38625 & GMP synthase [glutamine-hydrolyzing] & $\downarrow$ & 0.4 & 1.1 & 1.5 & 1 & 1.1 & 0.7 & 0.8 & 0.7 & 0.7 & 0.6 & 1.0 & 2 \\
\hline BeE60C24G08 & Q8XRKO & TDP-glucose-4,6-dehydratase-related protein & $\downarrow$ & & & & & 1.0 & 0.8 & 0.8 & 0.7 & 0.7 & 0.8 & 0.8 & 2 \\
\hline BeG120N09C02 & Q8NIH8 & Nuclease Le3 & $\downarrow$ & & & & & 1.2 & 1.3 & 1.0 & 0.9 & 0.6 & 0.7 & 1.0 & 2 \\
\hline BeG90N18B04 & & Adsl-prov protein & $\downarrow$ & & & & & 1.0 & 0.7 & & 0.5 & & 0.6 & 0.8 & 2 \\
\hline BeG60N01B06 & Q84P58 & $\begin{array}{l}\text { Adenosine kinase-like protein } \\
\text { probable inosine-5\'-monophosphate }\end{array}$ & $\downarrow$ & & & & & 1.0 & 0.8 & 0.6 & 0.7 & 0.4 & 0.5 & 0.7 & 2 \\
\hline BeZSPN03F10 & & dehydrogenase & $\uparrow$ & 1.1 & 1.5 & 1.4 & 3 & & & & & & & & \\
\hline BeE30N01E09 & & putative purine nucleoside phosphorylase & $\uparrow$ & 3.7 & 1.4 & 0.6 & 6 & 1.1 & 1.1 & 0.7 & 1.0 & 2.0 & 4.7 & 0.6 & 3 \\
\hline BeE30N07A05 & & Nucleoside phosphorylase & $\uparrow$ & 4.7 & 2.3 & 0.7 & 6 & 1.1 & 1.2 & 0.7 & 1.1 & 4.3 & 4.6 & 0.6 & 3 \\
\hline BeE90D15C05 & 094413 & Ribose-phosphate pyrophosphokinase & $\uparrow$ & 1.9 & 1.7 & 1.3 & 3 & 1.1 & 0.9 & 0.9 & 0.9 & 1.4 & 1.7 & 0.9 & 6 \\
\hline BeG90N19E11 & Q871N5 & Probable uracil phosphoribosyltransferase $\mathrm{F}$ & $\uparrow$ & 2.2 & 1.1 & 0.8 & 5 & 1.0 & 0.9 & 0.7 & 0.8 & 1.0 & 1.2 & 0.7 & 5 \\
\hline BeNSVP04F11 & & similar to cytidine deaminase & $\uparrow$ & 2.3 & 0.7 & 0.4 & 5 & 0.9 & 1.2 & & 1.3 & 2.6 & & 1.0 & 6 \\
\hline BeE120N25C08 & P20054 & Protein PYR1-3 & $\uparrow$ & & & & & 1.1 & 1.1 & 1.1 & 1.0 & 2.2 & 1.3 & 0.7 & 6 \\
\hline BeE60С10B01 & Q8D6V0 & Predicted nucleotidyltransferase & $\uparrow$ & & & & & & 1.1 & 0.9 & 1.4 & 2.3 & 1.5 & 1.3 & 6 \\
\hline BeE90D18C05 & 042806 & Cpa protein (Fragment) & $\uparrow$ & & & & & 1.0 & 1.0 & 0.9 & 0.9 & 2.2 & 1.5 & 0.5 & 6 \\
\hline \multicolumn{16}{|c|}{ Enovelamento e Modificação de Proteínas } \\
\hline BeE120N06H09 & 013351 & Ubiquitin-like protein smt3/pmt3 & $\downarrow$ & 0.5 & 0.7 & 1.2 & 1 & & & & & & & & \\
\hline BeE12ON2OHO4 & & putative protein serine/threonine kinase & $\downarrow$ & 0.9 & 0.7 & 0.8 & 4 & & & & & & & & \\
\hline BeE30N09G01 & Q9M4C4 & prefoldin subunit 4 VIP3 protein & $\downarrow$ & 0.6 & 0.8 & 1.1 & 1 & & & & & & & & \\
\hline BeE30N16B09 & 077622 & T-complex protein 1 , zeta subunit & $\downarrow$ & 0.7 & 0.9 & 0.9 & 1 & & & & & & & & \\
\hline BeE30N22H03 & Q9UTS & Hypothetical subtilase-type proteinase psp3 & $\downarrow$ & 0.6 & 0.9 & 1.2 & 1 & & & & & & & & \\
\hline BeE60H10E07 & & T-complex protein 1 , theta subunit & $\downarrow$ & 0.5 & 0.8 & 0.8 & 1 & & & & & & & & \\
\hline $\mathrm{BeE} 60 \mathrm{H} 22 \mathrm{A09}$ & Q13526 & Peptidyl-prolyl cis-trans isomerase & $\downarrow$ & 0.4 & 1.0 & 0.9 & 1 & & & & & & & & \\
\hline BeE60H30E02 & 06953 & $20 S$ proteasome subunit & $\downarrow$ & 0.5 & 0.9 & 0.7 & 1 & & & & & & & & \\
\hline BeE60H32E04 & 042993 & Peptidyl-prolyl cis-trans isomerase & $\downarrow$ & 0.6 & 0.7 & 0.8 & 1 & & & & & & & & \\
\hline BeE60N11B08 & Q9M77 & Putative serine/threonine protein kinase & $\downarrow$ & 0.6 & 0.7 & 0.9 & 1 & & & & & & & & \\
\hline BeE90D20D04 & P5999 & T-complex protein 1, delta subunit & $\downarrow$ & 0.7 & 0.9 & 0.9 & 1 & & & & & & & & \\
\hline BeG90N21H11 & & aminopeptidase-like 1 [Xenopus laevis & $\downarrow$ & 0.6 & 0.8 & 1.0 & 1 & & & & & & & & \\
\hline BeE60C24C07 & Q7ZA53 & Peptidyl-prolyl cis-trans isomerase & $\downarrow$ & 0.6 & 0.7 & 0.9 & 1 & 0.9 & 1.0 & 1.0 & 1.2 & 0.9 & 0.7 & 0.9 & 2 \\
\hline BeE60N07C06 & Q9UTM4 & T-complex protein 1 , epsilon subunit & $\downarrow$ & 0.5 & & & & 1.0 & 1.1 & 1.0 & 1.1 & 0.6 & 0.6 & 0.9 & 2 \\
\hline BeE60N07G09 & Q872U9 & Probable chaperonin of the TCP1 ring comple & $\downarrow$ & 0.7 & 0.8 & 0.8 & 1 & 1.0 & 0.9 & 0.9 & 1.0 & 0.6 & 0.7 & 0.7 & 2 \\
\hline BeE60N16F09 & Q95V46 & Chaperonin subunit 1 & $\downarrow$ & 0.6 & 0.9 & 1.0 & 1 & 1.1 & 1.0 & 0.9 & 1.0 & 0.6 & 0.7 & 0.8 & 2 \\
\hline BeG120N23B05 & Q99832 & $\begin{array}{l}\text { T-complex protein } 1 \text {, eta subunit } \\
\text { similar to Chaperonin containing TCP1, subunit } 4\end{array}$ & $\downarrow$ & 0.6 & 0.8 & 0.9 & 1 & 1.0 & 1.0 & 0.9 & 0.9 & 0.7 & 0.7 & 0.8 & 2 \\
\hline BeE60H30F05 & & (delta) & $\downarrow$ & & & & & 1.0 & 0.9 & 0.9 & 0.8 & 0.7 & 0.7 & 0.8 & 2 \\
\hline BeE60N15H02 & P24155 & Thimet oligopeptidase & $\downarrow$ & & & & & 1.1 & 0.9 & 1.0 & 0.8 & 0.7 & 0.6 & 0.9 & 2 \\
\hline BeG120N17H03 & P46595 & Ubiquitin-conjugating enzyme E2 4 & $\downarrow$ & & & & & 1.0 & 1.1 & 1.1 & 1.1 & 0.9 & 0.7 & 0.8 & 2 \\
\hline BeG90N16A03 & Q9VSF3 & NEDD8 conjugating enzyme Ubc12 & $\downarrow$ & & & & & 0.9 & 1.0 & 1.0 & 1.1 & 0.9 & 0.6 & 0.9 & 2 \\
\hline BeG90N22B10 & Q7Q8R2 & AgCP11849 (Fragment) & $\downarrow$ & & & & & 1.0 & 0.9 & 0.9 & 0.8 & 0.8 & 0.6 & 1.1 & 2 \\
\hline
\end{tabular}




\begin{tabular}{|c|c|c|c|c|c|c|c|c|c|c|c|c|c|c|c|}
\hline BeE60H29G11 & Q9P612 & Glutamate carboxypeptidase-like protein & $\uparrow$ & 1.5 & 1.1 & 1.2 & 3 & 1.0 & 1.2 & 1.0 & 1.5 & 1.6 & 1.6 & 1.4 & 4 \\
\hline BeE60N15G05 & & DnaJ-like protein MsJ1 - alfalfa & $\uparrow$ & 1.6 & 1.2 & 1.0 & 5 & 1.1 & 1.1 & 1.3 & 1.4 & 2.4 & 2.7 & 0.8 & 7 \\
\hline BeE60H15E02 & & DnaJ-class chaperone regulator [C. neoformans & $\uparrow$ & 1.4 & 1.0 & 0.8 & 5 & & & & & & & & \\
\hline BeE60N18G04 & 06178 & protein $\mathrm{N}$-terminal asparagine amidohydrolase & $\uparrow$ & 1.7 & 1.4 & 1.2 & 3 & & & & & & & & \\
\hline BeE90D03E05 & Q9NTU3 & Ubiquitin-activating enzyme 3 & $\uparrow$ & 1.6 & 1.5 & 1.0 & 3 & & & & & & & & \\
\hline BeG60N12E03 & 043447 & Peptidyl-prolyl cis-trans isomerase $\mathrm{H}$ & $\uparrow$ & 1.5 & 1.1 & 0.9 & 5 & & & & & & & & \\
\hline BeE90D05G05 & Q7Z8F2 & Putative serine/threonine phosphatase $2 \mathrm{C}$ ptc2 & $\uparrow$ & 2.3 & 1.9 & 0.9 & 5 & 1.0 & 1.3 & 1.5 & 2.2 & 4.9 & 4.8 & 0.9 & 7 \\
\hline BeG120N03B03 & & CasA & $\uparrow$ & 2.2 & 1.2 & 0.8 & 5 & 1.0 & 1.2 & 1.1 & 1.4 & 2.3 & 3.7 & 0.9 & 7 \\
\hline BeE60H17C06 & P52495 & Ubiquitin-activating enzyme E1 1 (Fragment) & $\uparrow$ & & & & & 1.0 & 1.1 & 1.1 & 1.4 & 1.1 & 1.1 & 0.7 & 6 \\
\hline \multirow[t]{2}{*}{$\mathrm{BeE} 60 \mathrm{H} 22 \mathrm{F09}$} & 074819 & POLYUBIQUITIN & $\uparrow$ & & & & & 0.9 & 1.2 & 1.2 & 1.4 & 1.3 & 1.5 & 1.2 & 6 \\
\hline & & Homeostase Redox & & & & & & & & & & & & & \\
\hline BeE60C19G01 & Q4IHX8 & Thioredoxin peroxidase & $\downarrow$ & 0.6 & 1.1 & 1.0 & 1 & & & & & & & & \\
\hline $\mathrm{BeE} 60 \mathrm{H} 29 \mathrm{E} 07$ & Q1137 & Superoxide dismutase [Cu-Zn] & $\downarrow$ & 0.6 & 0.8 & 0.9 & 1 & & & & & & & & \\
\hline BeE90N13F05 & Q9NL96 & Glutathione reductase & $\downarrow$ & 0.2 & 1.3 & 0.9 & 2 & & & & & & & & \\
\hline BeG120N18H03 & Q6DDA5 & Putative microsomal glutathione S-transferase 2 & $\downarrow$ & 0.6 & 1.1 & 0.9 & 1 & & & & & & & & \\
\hline BeG30N04A03 & 01427 & pyridoxine biosynthesis protein & $\downarrow$ & 0.5 & & & & & & & & & & & \\
\hline BeE30N14F04 & Q3M328 & Putative glutathione S-transferase-like 6 & $\uparrow$ & 1.8 & 1.2 & 1.0 & 5 & & & & & & & & \\
\hline BeE90D14B09 & & thioredoxin domain protein, DsbA family & $\uparrow$ & 1.0 & 1.7 & 1.5 & 3 & & & & & & & & \\
\hline BeE90D11E10 & Q16961 & Disulfide-like protein & $\uparrow$ & 1.4 & 1.2 & 1.0 & 5 & 1.0 & 1.0 & 0.9 & 1.1 & 1.3 & 2.3 & 1.1 & 6 \\
\hline BeE30N18H03 & & $\begin{array}{l}\text { Pyridoxamine } 5 \text { '-phosphate oxidase-related, FMN- } \\
\text { binding protein }\end{array}$ & $\uparrow$ & & & & & 1.1 & 1.2 & 0.9 & 1.1 & 1.2 & 1.4 & 1.0 & 6 \\
\hline BeE60N14F11 & Q9BGI3 & Peroxiredoxin 2 & $\uparrow$ & & & & & 0.7 & 1.1 & 1.2 & 1.3 & 1.3 & 1.3 & 1.1 & 6 \\
\hline \multirow[t]{2}{*}{ BeE90D18F01 } & P40581 & Glutathione peroxidase 3 & $\uparrow$ & & & & & 0.9 & 1.1 & 1.3 & 1.4 & 1.2 & 1.5 & 1.2 & 6 \\
\hline & & Proteínas Ribossômicas / Tradução & & & & & & & & & & & & & \\
\hline BeE120N37D12 & P38665 & $60 S$ ribosomal protein $\mathrm{L} 24$ & $\downarrow$ & 1.0 & 0.6 & 1.0 & 4 & & & & & & & & 6 \\
\hline BeE60H23E04 & 042952 & $40 S$ ribosomal protein & $\downarrow$ & 0.6 & 0.7 & 1.0 & 1 & & & & & & & & \\
\hline BeE60N19C01 & 074966 & Probable small nuclear ribonucleoprotein G & $\downarrow$ & 0.9 & 0.6 & 1.0 & 4 & & & & & & & & \\
\hline BeE90D08E09 & Q9XGL4 & $60 S$ ribosomal protein $\mathrm{L} 31$ & $\downarrow$ & 0.7 & 1.0 & 0.9 & 1 & & & & & & & & \\
\hline BeG120N01H09 & & structural constituent of ribosome [C. neoformans & $\downarrow$ & 0.6 & 0.8 & 1.0 & 1 & & & & & & & & \\
\hline BeG120N10H02 & Q95V37 & ribosomal protein L29 [Bombyx mori] & $\downarrow$ & 0.6 & 0.9 & & & & & & & & & & \\
\hline BeG90N04A04 & & Probable eukaryotic translation initiation factor & $\downarrow$ & 0.6 & 0.7 & 1.1 & 1 & & & & & & & & \\
\hline BeG90N09C08 & & Elongation factor $\mathrm{G} 1$, mitochondrial precursor ( $\mathrm{mE}$ & $\downarrow$ & & 0.3 & 1.3 & & & & & & & & & \\
\hline BeG90N15C05 & Q9S826 & Putative U3 small nucleolar ribonucleoprotein & $\downarrow$ & 1.0 & 0.7 & 1.0 & 4 & & & & & & & & \\
\hline BeE30N15A04 & P7983 & Eukaryotic translation initiation factor 3 & $\downarrow$ & 0.7 & 0.7 & 1.0 & 1 & 1.0 & 0.9 & 0.8 & 0.8 & 0.5 & 0.6 & 1.0 & \\
\hline BeG120N20E02 & Q9NPE3 & H/ACA ribonucleoprotein complex subunit 3 & $\downarrow$ & 0.4 & 0.4 & 0.9 & 2 & 0.9 & 0.9 & 1.1 & 0.9 & 0.3 & 0.3 & 1.3 & 2 \\
\hline BeG60N15D01 & 07469 & SNU13 snRNP subunit homolog & $\downarrow$ & 0.6 & 0.5 & 0.9 & 1 & 1.0 & 0.9 & 0.9 & 0.8 & 0.4 & 0.2 & 1.2 & 1 \\
\hline BeG90N02G11 & & phenylalanine-tRNA ligase & $\downarrow$ & 0.9 & & 0.5 & & & 0.9 & 1.0 & 0.9 & 0.4 & 0.9 & 1.0 & 1 \\
\hline BeG90N10A10 & P32495 & High mobility group & $\downarrow$ & & 0.5 & 0.9 & & 1.0 & 1.0 & 0.9 & 0.9 & 0.5 & 0.4 & 1.2 & 2 \\
\hline BeG120N22D07 & Q556 & Arginyl tRNA synthetase, cytoplasmic & $\downarrow$ & 0.7 & 0.6 & 1.2 & 1 & 1.0 & 1.1 & 1.3 & 1.0 & 0.5 & 0.5 & 1.7 & 1 \\
\hline BeNSVP10C04 & & elF3/signalosome protein & $\downarrow$ & 0.6 & & & & 0.9 & 0.9 & 1.0 & 0.7 & 0.5 & 0.5 & 1.3 & 1 \\
\hline BeE30N13H12 & & lysyl-tRNA synthetase & $\downarrow$ & & & & & 1.0 & 1.0 & 0.9 & 0.8 & 0.6 & 0.6 & 1.0 & 2 \\
\hline BeE30N18E04 & & glycyl-tRNA synthetase & $\downarrow$ & & & & & 1.0 & 0.9 & 0.8 & 0.8 & 0.7 & 0.8 & 0.9 & 2 \\
\hline BeE30N22E01 & 014339 & $60 S$ ribosomal protein L17-A & $\downarrow$ & & & & & 0.9 & 0.9 & 0.8 & 0.8 & 0.7 & 0.7 & 0.8 & 2 \\
\hline BeE60H15C05 & P87144 & $\begin{array}{l}\text { Threonyl-tRNA synthetase, cytoplasmic } \\
\text { Homo sapiens eukaryotic translation initiation factor }\end{array}$ & $\downarrow$ & & & & & 1.0 & 1.0 & 1.2 & 1.0 & 0.6 & 0.7 & 1.1 & 2 \\
\hline BeG120N04E02 & & $1 \mathrm{~A}$ & $\downarrow$ & & & & & 0.9 & 0.9 & 0.9 & 0.8 & 0.7 & 0.6 & 1.0 & 2 \\
\hline BeG120N11F05 & & similar to Eukaryotic translation initiation factor & $\downarrow$ & & & & & 0.9 & 1.1 & 0.9 & 0.9 & 0.6 & 0.6 & 1.1 & 2 \\
\hline
\end{tabular}




\begin{tabular}{|c|c|c|c|c|c|c|c|c|c|c|c|c|c|c|c|}
\hline BeG120N13E04 & Q9HGT6 & Seryl-tRNA synthetase, cytoplasmic & $\downarrow$ & & & & & 1.1 & 1.0 & 1.0 & 0.9 & 0.8 & 0.7 & 1.1 & 2 \\
\hline BeG30N06D06 & & $(\mathrm{elF}-5)$ & $\downarrow$ & & & & & 1.0 & 1.2 & 0.9 & 0.9 & 0.6 & 0.7 & 1.1 & 2 \\
\hline BeG30N13C06 & 014044 & Ribosomal RNA processing protein 28 & $\downarrow$ & & & & & 0.9 & 1.1 & & 0.9 & & 0.6 & 1.0 & 2 \\
\hline BeZSPN06C04 & Q09692 & tryptophanyl-tRNA synthetase & $\downarrow$ & & & & & 1.1 & 1.0 & 1.2 & 1.1 & 0.6 & 0.9 & 1.6 & 2 \\
\hline BeZSPN17H02 & & similar to Fibrillarin CG9888PA & $\downarrow$ & & & & & 1.0 & 1.0 & 0.9 & 0.9 & 0.5 & 0.4 & 1.1 & 2 \\
\hline BeE60N04D02 & Q9CHN6 & Elongation factor $\mathrm{P}$ & $\uparrow$ & 1.1 & 1.4 & 1.3 & 3 & & & & & & & & 1 \\
\hline BeG30N13H07 & Q13685 & ribosome biogenesis protein Sqt1 & $\uparrow$ & 1.2 & & 0.4 & & & & & & & & & \\
\hline BeG90N19F12 & P29691 & Elongation factor 2 & $\uparrow$ & 1.2 & 1.6 & 0.5 & 5 & & & & & & & & \\
\hline BeG90N07C02 & Q84KQ4 & Elongation factor-1alpha (Fragment) & $\uparrow$ & & & & & 1.0 & 1.1 & 1.0 & 1.1 & 1.5 & 1.6 & 0.9 & \\
\hline BeNSVPO7H09 & Q84KQ4 & Elongation factor-1alpha (Fragment) & $\uparrow$ & & & & & & 1.1 & 1.3 & 1.1 & 1.4 & 1.4 & & 6 \\
\hline \multicolumn{16}{|c|}{ Transdução de Sinal } \\
\hline BeE120N02E04 & Q7YXG1 & soluble guanylyl cyclase 2 beta & $\downarrow$ & 1.0 & 0.5 & 0.6 & 4 & & & & & & & & \\
\hline BeE60N16D02 & P3446 & Guanine nucleotide-binding protein alpha-8 & $\downarrow$ & 0.4 & 0.8 & 0.8 & 2 & & & & & & & & \\
\hline BeG90N08A02 & Q9W7I1 & activated protein kinase $\mathrm{C}$ receptor & $\uparrow$ & 0.9 & 1.4 & 1.1 & 3 & & & & & & & & \\
\hline BeZSPN16D09 & Q12741 & cAMP-dependent protein kinase catalytic sub & $\uparrow$ & 1.2 & 1.4 & 1.3 & 3 & & & & & & & & \\
\hline \multicolumn{16}{|c|}{ Resposta a Estresse } \\
\hline BeZSPN11F03 & & $10 \mathrm{kDa}$ heat shock protein, mitochondrial & $\downarrow$ & 0.5 & 0.6 & 0.9 & 1 & 1.0 & 0.9 & 0.8 & 0.8 & 0.4 & 0.4 & 0.8 & 1 \\
\hline $\mathrm{BeG60N07C03}$ & Q9S9N1 & Hsp70-3 (Blastocladiella emersonii) & $\downarrow$ & & & & & 1.1 & 1.0 & 0.8 & 0.8 & 0.6 & 0.7 & 1.0 & 2 \\
\hline $\mathrm{BeE} 60 \mathrm{H} 20 \mathrm{C0} 0$ & P22774 & Hsp70-9 (Blastocladiella emersonii) & $\uparrow$ & 5.9 & 2.2 & 0.5 & 6 & 1.0 & 0.9 & 0.6 & 1.2 & 4.0 & 4.4 & 0.5 & 3 \\
\hline BeE60H29E01 & & putative stress-related protein & $\uparrow$ & 2.2 & 1.5 & 0.7 & 5 & 1.0 & 1.1 & 0.8 & 1.2 & 1.6 & 2.2 & 0.9 & 6 \\
\hline \multicolumn{16}{|c|}{ Estrutura Celular / Microtúbulos } \\
\hline BeE120N07A12 & & roadblock-related dynein light chain & $\downarrow$ & 0.6 & 0.7 & 1.1 & 1 & & & & & & & & \\
\hline BeE60N12E01 & Q9196 & Myosin regulatory light chain cdc4 & $\downarrow$ & 0.7 & & & & & & & & & & & \\
\hline BeE90N17C06 & Q9SMH3 & Dynein 1-alpha heavy chain & $\downarrow$ & 0.4 & 0.9 & 0.9 & 1 & & & & & & & & \\
\hline BeE60H23E05 & & calponin/transgelin & $\uparrow$ & 1.5 & 1.0 & 0.7 & 5 & & & & & & & & \\
\hline BeG30N07C04 & P25323 & Myosin light chain kinase & $\uparrow$ & 1.6 & & 0.3 & & & & & & & & & \\
\hline BeE60N03E07 & & beta-tubulin & $\uparrow$ & 1.4 & 1.5 & 1.0 & 3 & 1.1 & 1.2 & 1.0 & 1.2 & 1.4 & 1.8 & 0.9 & 6 \\
\hline BeE60N12G09 & P7436 & Tubulin beta- 1 chain & $\uparrow$ & 1.4 & 1.3 & 1.1 & 3 & 1.2 & 1.0 & 1.0 & 1.2 & 1.2 & 1.7 & 0.9 & 6 \\
\hline BeE60H28B01 & P10989 & Actin & $\uparrow$ & & & & & 1.0 & 1.2 & 1.2 & 1.2 & 1.3 & 1.6 & 0.9 & 6 \\
\hline BeE60N13F03 & & beta-tubulin & $\uparrow$ & & & & & 1.0 & 1.1 & 1.0 & 1.3 & 1.4 & 1.5 & 0.9 & 6 \\
\hline BeE90D08H04 & Q9UFH2 & Axonemal beta dynein heavy chain 17 & $\uparrow$ & & & & & & 0.9 & 0.9 & 1.0 & 2.2 & 1.2 & 1.4 & 6 \\
\hline \multicolumn{16}{|c|}{ Transcrição / Processamento de RNA } \\
\hline BeE90D17A08 & Q7ZY47 & ATP-dependent RNA helicase DDX42 & $\downarrow$ & 0.3 & 1.0 & 0.8 & 2 & & & & & & & & \\
\hline BeZSPN12F04 & Q3532 & Probable ATP-dependent RNA helicase HAS1 & $\downarrow$ & 0.9 & 0.7 & 1.0 & 4 & & & & & & & & \\
\hline BeG120N02A10 & Q9916 & Putative ATP dependent RNA helicase C1F7.02 & $\downarrow$ & 0.6 & 0.6 & 0.9 & 1 & 1.0 & 1.0 & 0.9 & 0.9 & 0.4 & & 1.1 & 1 \\
\hline BeE3ON22H05 & 08198 & RNA polymerase I, II and III $24.3 \mathrm{kDa}$ subun & $\downarrow$ & 0.2 & 0.7 & 1.0 & 2 & & & & & & & & \\
\hline BeE90D16F01 & Q9P6Q6 & mRNA-capping enzyme subunit beta & $\downarrow$ & & 0.5 & & & & & & & & & & \\
\hline BeG90N17F03 & Q9NQT4 & exosome component Rrp46 [Homo sapiens] & $\downarrow$ & 1.2 & 0.5 & 0.5 & 4 & & & & & & & & \\
\hline BeZSPN17G09 & Q8BU5 & DNA-directed RNA polymerases III 12.5 kDa & $\downarrow$ & 0.8 & 0.6 & 0.9 & 4 & & & & & & & & \\
\hline BeE30N15E05 & $\mathrm{P} 2441$ & Ras-related protein Rab-11A & $\downarrow$ & 0.5 & 0.6 & 1.2 & 1 & 1.0 & 1.0 & 1.0 & 0.9 & 0.7 & 0.6 & 1.2 & 2 \\
\hline BeG90N10B01 & & DNA-directed RNA polymerase I subunit D protein & $\downarrow$ & 0.6 & 0.6 & 1.0 & 1 & 0.9 & 1.0 & 0.9 & 0.9 & 0.5 & 0.5 & 1.3 & 2 \\
\hline BeE60N18A09 & Q9UVL1 & Nonhistone protein 6 & $\downarrow$ & & & & & 0.9 & 1.0 & 1.0 & 1.0 & 0.8 & 0.6 & 0.7 & 2 \\
\hline BeG60N07D01 & Q8MYR3 & La related protein & $\downarrow$ & & & & & 1.0 & 1.0 & 0.8 & 0.7 & 0.6 & 0.6 & 1.2 & 2 \\
\hline BeE90D08E03 & & RNA polymerase II elongator-associated protein & $\uparrow$ & 2.1 & 1.7 & 0.9 & 5 & 1.0 & 1.2 & 1.5 & 2.0 & 3.9 & 4.5 & 0.9 & 7 \\
\hline \multicolumn{16}{|c|}{ Transporte } \\
\hline BeE120N01A01 & Q87C4 & Cationic amino acid transporter & $\downarrow$ & 0.5 & 0.8 & 0.8 & 1 & & & & & & & & \\
\hline
\end{tabular}




\begin{tabular}{|c|c|c|c|c|c|c|c|c|c|c|c|c|c|c|c|}
\hline BeE120N35H01 & Q7SAQ1 & Clathrin assembly protein 2 small chain & $\downarrow$ & 0.6 & 0.6 & 0.7 & 1 & & & & & & & & \\
\hline $\mathrm{BeE} 60 \mathrm{H} 21 \mathrm{G} 09$ & Q8RBT1 & Amino acid transporters & $\downarrow$ & 1.0 & 0.7 & 0.8 & 4 & & & & & & & & \\
\hline BeE90D19D08 & Q8T665 & $\mathrm{ABC}$ transporter $\mathrm{AbcH} .1$ & $\downarrow$ & 0.6 & 1.0 & 0.9 & 1 & & & & & & & & \\
\hline BeG120N07E03 & Q9P8H & $\begin{array}{l}\text { nuclear transport factor } 2 \text { (ntf-2), putative } \\
\text { high affinity methionine permease [Aspergillus }\end{array}$ & $\downarrow$ & 0.6 & 0.8 & 1.1 & 1 & & & & & & & & \\
\hline BeG90N14C01 & & clavatus & $\downarrow$ & & 0.2 & & & & & & & & & & \\
\hline BeE30N06H12 & & Peptide transporter PepT1 & $\downarrow$ & 0.7 & 0.7 & 1.0 & 1 & 1.0 & 0.9 & 0.9 & 0.8 & 0.6 & 0.7 & 0.9 & 2 \\
\hline BeE30N10D02 & Q6593 & Oligopeptide transporter 2 & $\downarrow$ & 0.4 & 0.1 & 1.0 & 8 & 1.1 & 1.0 & 1.2 & 1.1 & 0.5 & 0.5 & 0.7 & 1 \\
\hline BeE30N17A03 & P4897 & High affinity transporter for glutathione & $\downarrow$ & 0.3 & 0.5 & 0.8 & 2 & 1.0 & 1.0 & 1.1 & 1.1 & 0.4 & 0.4 & 0.8 & 1 \\
\hline BeE60N10A01 & P38264 & Inorganic phosphate transporter $\mathrm{PHO} 88$ & $\downarrow$ & 0.4 & 0.7 & 1.4 & 1 & 0.9 & 0.8 & 0.7 & 0.7 & 0.3 & 0.3 & 0.8 & 1 \\
\hline BeE60N13C09 & P7144 & Outer mitochondrial membrane protein porin & $\downarrow$ & 0.7 & 0.8 & 0.9 & 1 & 1.0 & 0.9 & 0.7 & 0.9 & 0.5 & 0.5 & 0.8 & 2 \\
\hline BeG60N20F09 & Q87216 & Probable iron inhibited $A B C$ transporter 2 & $\downarrow$ & 0.7 & 0.7 & 1.0 & 1 & 1.0 & 1.0 & 1.1 & 1.0 & 0.7 & 0.7 & 1.4 & 2 \\
\hline BeG90N09B05 & & proton-glutamate symporter & $\downarrow$ & 0.5 & & & & 1.1 & 0.9 & 0.8 & 0.5 & 0.4 & 0.4 & 0.7 & 2 \\
\hline BeE120N04F11 & & putative mitochondrial carrier protein & $\downarrow$ & & & & & 1.0 & 0.8 & 0.8 & 0.7 & 0.7 & 0.7 & 0.7 & 2 \\
\hline BeE60H30F10 & Q10481 & $\begin{array}{l}\text { Mitochondrial import inner membrane translocase } \\
\text { subunit tim13 }\end{array}$ & $\downarrow$ & & & & & 1.1 & 0.9 & 1.0 & 0.9 & 0.8 & 0.7 & 1.1 & 2 \\
\hline BeE60N18A11 & & $\begin{array}{l}\text { putative phosphate/phosphoenolpyruvate } \\
\text { translocator }\end{array}$ & $\downarrow$ & & & & & 1.0 & 1.0 & 0.9 & 1.0 & 0.8 & 0.6 & 0.8 & 2 \\
\hline BeG120N24A07 & Q8H727 & ADP/ATP translocase & $\downarrow$ & & & & & & 1.2 & 1.0 & 0.7 & 0.6 & 0.7 & 0.8 & 2 \\
\hline BeG30N12H02 & & probable amino acid transporter & $\downarrow$ & & & & & 1.0 & 1.1 & 1.1 & 1.2 & 0.8 & 0.7 & 1.0 & 2 \\
\hline BeG30N19C05 & Q63424 & Oligopeptide transporter, kidney isoform & $\downarrow$ & & & & & & 0.8 & 0.7 & 0.6 & 0.8 & 0.5 & 1.0 & 2 \\
\hline BeG90N09D08 & 074700 & $\begin{array}{l}\text { Mitochondrial import inner membrane translocase } \\
\text { subunit TIM9 }\end{array}$ & $\downarrow$ & & & & & 0.9 & 0.8 & 0.8 & 0.6 & 0.6 & 0.4 & 1.0 & 1 \\
\hline BeG90N16G06 & Q9UUY0 & calcium P-type ATPase & $\downarrow$ & & & & & 1.0 & 1.0 & 1.0 & 0.9 & 0.7 & 0.6 & 0.9 & 2 \\
\hline BeZSPN05F06 & & hypothetical protein [Neurospora crassa] & $\downarrow$ & & & & & 1.0 & 1.0 & 1.0 & 0.9 & 0.7 & 0.8 & 1.5 & 2 \\
\hline BeZSPN15C05 & & high-affinity iron permease [Rhizopus oryzae] & $\downarrow$ & & & & & & 0.9 & & 0.8 & & 0.6 & 0.5 & 2 \\
\hline BeE90N13G10 & P21851 & dapter-related protein complex 2 beta 1 subunit & $\uparrow$ & 1.3 & 1.5 & 1.0 & 3 & & & & & & & & \\
\hline BeG120N07C03 & Q84VI6 & Phosphate transporter HvPT7 & $\uparrow$ & 1.2 & 1.3 & 1.3 & 3 & & & & & & & & \\
\hline BeG60N01F09 & & methionine permease, putative [Neosartorya fischeri & $\uparrow$ & 1.6 & 2.1 & 0.9 & 3 & & & & & & & & \\
\hline BeG90N07C10 & Q8TGD1 & tricarboxylate carrier, putative & $\uparrow$ & 1.2 & 2.2 & 0.6 & 5 & & & & & & & & \\
\hline BeE60H32G06 & P15847 & Trafficking protein particle complex subunit 5 & $\uparrow$ & 3.0 & 1.9 & 0.9 & 6 & 0.9 & 0.9 & 1.1 & 1.4 & 3.6 & 9.2 & 0.7 & 3 \\
\hline BeE60N12D06 & Q9JL62 & Glycolipid transfer protein & $\uparrow$ & 2.3 & 1.7 & 1.1 & 5 & 1.0 & 1.3 & 1.3 & 1.9 & 2.8 & 2.8 & 1.0 & 7 \\
\hline BeG120N22G10 & & MFS quinate transporter & $\uparrow$ & 1.4 & 1.0 & 0.6 & 5 & 1.0 & 1.0 & 1.1 & 1.2 & 1.7 & 1.0 & 0.9 & 6 \\
\hline BeG90N01D10 & Q8WZW8 & Probable YHM1 mitochondrial carrier protein & $\uparrow$ & 1.6 & 1.0 & 0.9 & 5 & 1.0 & 0.9 & 0.8 & 0.8 & 0.9 & 0.8 & 0.7 & 5 \\
\hline BeG90N16C06 & P42833 & Hexose transporter HXT14 & $\uparrow$ & 2.0 & 1.0 & 0.4 & 5 & 1.1 & 0.9 & 1.2 & 1.5 & 1.9 & 1.1 & 1.0 & 6 \\
\hline BeNSVP07B10 & & proton glutamate symport protein & $\uparrow$ & 0.9 & 1.6 & 1.0 & 3 & 0.8 & 0.8 & 1.0 & 1.2 & 1.4 & 1.8 & 1.0 & 6 \\
\hline \multirow[t]{2}{*}{ BeZSPN02C07 } & & $\begin{array}{l}\text { hypothetical nicotinamide mononucleotide } \\
\text { transporter }\end{array}$ & $\uparrow$ & & & & & 0.9 & 1.1 & 1.1 & 1.0 & 1.2 & 1.6 & 1.1 & 6 \\
\hline & & \multicolumn{13}{|l|}{ Transposição } & \\
\hline BeE60H29B05 & & Putative transposase & $\downarrow$ & & & & & 1.0 & 0.7 & 0.9 & 0.9 & 0.6 & 0.5 & 1.1 & 2 \\
\hline BeZSPN17B12 & & Putative transposase & $\downarrow$ & & & & & 0.9 & 0.8 & 0.8 & 0.9 & 0.7 & 0.6 & 1.2 & 2 \\
\hline \multicolumn{15}{|c|}{ Outros } & \\
\hline BeE30N07B02 & & Calmodulin (CaM) & $\downarrow$ & 0.6 & 0.8 & & & & & & & & & & \\
\hline BeE60C05B10 & Q882A7 & Oxidoreductase, Gfo/Idh/MocA family & $\downarrow$ & 0.5 & 0.7 & 0.9 & 1 & & & & & & & & \\
\hline BeE60C06H06 & Q7WWT9 & Putative NagM-like protein & $\downarrow$ & 0.7 & 0.7 & 0.8 & 4 & & & & & & & & \\
\hline BeE60C15B06 & Q91264 & Fe2+-dicitrate sensor & $\downarrow$ & 0.3 & 0.9 & 0.8 & 2 & & & & & & & & \\
\hline BeE60N16C10 & & fiber protein Fb27 [Gossypium barbadense] & $\downarrow$ & 0.1 & 0.9 & 0.9 & 2 & & & & & & & & \\
\hline BeE60N18G11 & & bud site selection-related protein, putative [Cryp & $\downarrow$ & 0.1 & & 1.0 & & & & & & & & & \\
\hline BeE90N19D05 & Q8NFV4 & similar to abhydrolase domain containing 11 & $\downarrow$ & & 0.2 & & & & & & & & & & \\
\hline
\end{tabular}




\begin{tabular}{|c|c|c|c|c|c|c|c|c|c|c|c|c|c|c|c|}
\hline BeE9ON2OH07 & Q7VUP2 & Putative hydrolase & $\downarrow$ & 0.4 & & & & & & & & & & & \\
\hline BeG60N01F08 & & zinc finger protein, putative [Cryptococcus neofor & $\downarrow$ & 0.7 & 0.8 & 0.9 & 1 & & & & & & & & \\
\hline BeG90N03C01 & 074362 & Conserved hypothetical protein & $\downarrow$ & 1.0 & 0.2 & 0.4 & 8 & & & & & & & & \\
\hline BeE120N27B06 & & pyrimidine 5 '-nucleotidase, putative & $\downarrow$ & 0.6 & 0.8 & 1.0 & 1 & 1.0 & 1.1 & 1.0 & 1.1 & 0.7 & 1.0 & 1.7 & 4 \\
\hline BeE60H31F05 & & similar to DC6 & $\downarrow$ & 0.5 & 0.8 & 1.0 & 1 & 0.9 & 0.8 & 0.9 & 0.7 & 0.6 & 0.6 & 1.0 & 2 \\
\hline BeE60N16C07 & & similar to armadillo repeat containing 4 & $\downarrow$ & 0.5 & 0.8 & 1.3 & 1 & 1.0 & 0.7 & 0.7 & 0.8 & 0.4 & 0.3 & 0.8 & 1 \\
\hline BeE90N06H03 & Q81CV & Hydrolase & $\downarrow$ & 0.0 & 0.1 & & & & 0.4 & 0.7 & 0.2 & & 0.3 & 1.2 & 8 \\
\hline BeG120N02B04 & P32469 & Diphthine synthase & $\downarrow$ & 0.5 & 0.5 & 0.9 & 1 & 1.0 & 1.0 & 0.8 & 0.9 & 0.5 & 0.4 & 1.1 & 1 \\
\hline BeG30N06H12 & Q8NEY6 & Gastric cancer antigen Zg14 (Fragment) & $\downarrow$ & 0.6 & 0.7 & 1.0 & 1 & 1.0 & 1.0 & 1.0 & 0.9 & 0.6 & 0.6 & 1.3 & 2 \\
\hline BeG30N20D08 & Q9UUG1 & Brix domain containing protein 1 homolog & $\downarrow$ & 0.5 & 0.7 & 1.0 & 1 & 0.9 & 1.2 & 0.9 & 0.9 & & 0.4 & 1.2 & 1 \\
\hline BeG60N08E04 & 042468 & PP2A inhibitor & $\downarrow$ & 0.5 & 0.6 & 1.0 & 1 & 1.0 & 1.1 & 0.7 & 0.8 & 0.3 & 0.3 & 1.2 & 1 \\
\hline BeE30N06D09 & & $\mathrm{N}$-alpha-acetyltransferase major subunit & $\downarrow$ & & & & & 1.0 & 0.9 & 0.8 & 0.8 & 0.7 & 0.6 & 0.9 & 2 \\
\hline BeE30N13C08 & Q91V01 & Putative transmembrane protein & $\downarrow$ & & & & & 1.0 & 1.1 & 1.0 & 1.0 & 0.8 & 0.6 & 0.9 & 2 \\
\hline BeE60N13A07 & P53011 & $\begin{array}{l}\text { Nuclear pore protein SEH1 } \\
\text { similar to required for meiotic nuclear division } 5\end{array}$ & $\downarrow$ & & & & & 1.2 & 0.8 & 0.9 & 0.8 & 0.5 & 0.5 & 0.7 & 2 \\
\hline BeE60N16E08 & & homolog A & $\downarrow$ & & & & & 1.1 & 1.0 & 0.9 & 0.9 & 0.7 & 0.6 & 0.8 & 2 \\
\hline BeE60N17D11 & 014220 & Meiotic expression up-regulated protein 26 & $\downarrow$ & & & & & 0.9 & 1.0 & 0.9 & 1.0 & 0.8 & 0.6 & 0.8 & 2 \\
\hline BeE60N19G04 & & similar to PRIP-interacting protein PIPMT & $\downarrow$ & & & & & & 0.9 & 0.8 & 0.9 & 0.6 & 0.5 & 1.0 & 2 \\
\hline BeG30N05D12 & & protein arginine $n$-methyltransferase 1 & $\downarrow$ & & & & & 0.9 & 1.1 & 1.1 & 1.1 & 0.6 & 0.5 & 1.3 & 1 \\
\hline BeG60N19A03 & Q9W3Y0 & RE14402p Zinc finger protein & $\downarrow$ & & & & & 0.9 & 1.0 & 1.1 & 1.0 & 0.5 & 0.6 & 1.2 & 2 \\
\hline BeZSPN15C05 & Q09919 & Hypothetical protein C1F7.07c in chromosome & $\downarrow$ & & & & & & 0.9 & & 0.8 & & 0.6 & 0.5 & 2 \\
\hline BeE120N37B07 & Q9C5 & Dpy-30-like protein & $\uparrow$ & 1.1 & 1.6 & 1.2 & 3 & & & & & & & & \\
\hline BeE30N02D01 & & Vacuolar protein sorting-associated protein 26 & $\uparrow$ & 1.8 & 1.6 & 1.0 & 5 & & & & & & & & \\
\hline BeE30N20C05 & P97834 & COP9 signalosome complex subunit 1 & $\uparrow$ & 1.4 & 1.0 & 1.1 & 5 & & & & & & & & \\
\hline $\mathrm{BeE} 60 \mathrm{H} 32 \mathrm{~A} 03$ & Q7YZR8 & ferritin GF2 & $\uparrow$ & 1.7 & 1.3 & 0.7 & 5 & & & & & & & & \\
\hline BeE60N03D02 & Q83L76 & putative phosphohydrolase & $\uparrow$ & 1.4 & 1.3 & 1.1 & 3 & & & & & & & & \\
\hline BeE60N10G01 & 094453 & Ubiquinone biosynthesis protein $\mathrm{COQ} 4$ & $\uparrow$ & 1.8 & 1.5 & 1.0 & 5 & & & & & & & & \\
\hline BeG30N14G08 & Q7XJ13 & Chloroplast nucleoid DNA-binding protein-li & $\uparrow$ & 1.2 & & 0.2 & & & & & & & & & \\
\hline BeZSPN14F11 & Q8AVD5 & Similar to Benzodiazepin receptor & $\uparrow$ & 1.6 & & & & & & & & & & & \\
\hline BeZSPN16C07 & Q9251 & similar to Ring finger protein 121 & $\uparrow$ & 1.6 & & & & & & & & & & & \\
\hline BeE30N07B04 & P53326 & Hypothetical 81.2 kDa protein in MES1-FOL2 & $\uparrow$ & 1.7 & 1.4 & 0.9 & 5 & 1.0 & 1.0 & 1.2 & 1.7 & 2.4 & 2.8 & 1.4 & 7 \\
\hline BeE60N13B06 & Q8AVD5 & Similar to Benzodiazepin receptor & $\uparrow$ & 2.2 & 1.8 & & & 1.0 & 0.9 & 0.8 & 1.1 & 1.5 & 2.1 & 0.7 & 6 \\
\hline BeG120N23D09 & & putative protein disulfate isomerase & $\uparrow$ & 1.5 & 1.8 & 1.1 & 3 & 1.0 & 1.2 & 1.2 & 1.5 & 1.9 & 1.6 & 0.8 & 6 \\
\hline BeZSPN05D01 & & similar to Protein Mo25 (dMo25) & $\uparrow$ & 1.8 & & 1.2 & & 0.9 & 1.2 & 1.0 & 1.3 & 1.5 & 1.9 & 1.0 & 6 \\
\hline BeZSPN10F11 & & Multitransmembrane protein (ISS) & $\uparrow$ & 1.7 & & 1.3 & & 1.1 & 1.1 & 1.1 & 1.5 & 1.7 & 1.6 & 1.1 & 6 \\
\hline BeG90N06G12 & & acyl-coA-binding protein, ACBP & $\uparrow$ & & & & & 1.0 & 1.1 & 1.2 & 1.5 & 1.6 & 1.5 & 1.0 & 6 \\
\hline
\end{tabular}

Para melhor compreender a resposta transcricional de $B$. emersonii à carência de oxigênio, analisaremos a seguir, com mais detalhes, as categorias funcionais mais marcantes e suas correlações com o estresse de hipóxia. 


\subsubsection{No Match}

Como pode ser observado na Figura 15, uma grande fração $(\sim 40 \%)$ dos genes afetados pela concentração de oxigênio dissolvido não possuem similaridade com nenhuma sequência depositada no GenBank e estão anotados como No Match. Isto se deve provavelmente ao alto número de No Matches depositados nas lâminas de microarranjo (cerca de 56\%). Se por um lado isto representa certa limitação, por outro lado não deixa de ser intrigante que existam tantos genes sem função conhecida participando da resposta deste fungo à carência de oxigênio.

\subsubsection{Metabolismo de Aminoácidos}

A maioria dos genes afetados por hipóxia que codificam proteínas relacionadas ao metabolismo de aminoácidos, apresentou um perfil de repressão. Dentre os reprimidos estão genes que participam da biossíntese de diversos aminoácidos, como: ornithine-oxo-acid transaminase (prolina e arginina), 2-isopropylmalate synthase (leucina), cysteine synthase (cisteína), acetolactate synthase Ilv2 (valina, leucina e isoleucina), aspartokinase (metionina, lisina e treonina), histidinol phosphate aminotransferase (histidina) e 5methyltetrahydropteroyltriglutamate--homocysteine methyltransferase (metionina). Além disso, também está reprimido o gene que codifica a enzima arginase, que participa da última etapa do ciclo da uréia.

Outro importante gene reprimido é o que codifica uma glutamato desidrogenase (glutamate dehydrogenase 3). Esta enzima transforma glutamato em $\alpha$-cetoglutarato, alimentando o ciclo do ácido cítrico. Sua repressão é condizente com o estado de hipóxia, no qual a falta de oxigênio inviabiliza o funcionamento normal do ciclo do ácido cítrico.

Dois genes que foram fortemente reprimidos e merecem destaque são os que codificam a enzima 5-methyltetrahydropteroyltriglutamate--homocysteine methyltransferase 
e a enzima S-adenosylmethionine synthetase. Essas duas enzimas são responsáveis pela biossíntese de S-adenosil metionina (SAM ou AdoMet) (Figura 16), molécula com um importante papel em processos biossintéticos, através da metilação de ácidos nucléicos, fosfolipídeos, aminas e proteínas. A forte repressão desses genes e a provável diminuição na síntese de SAM devem estar relacionadas à economia de energia necessária à célula sob carência de oxigênio, uma vez que os processos biossintéticos dependentes de SAM são bastante dispendiosos em ATP.

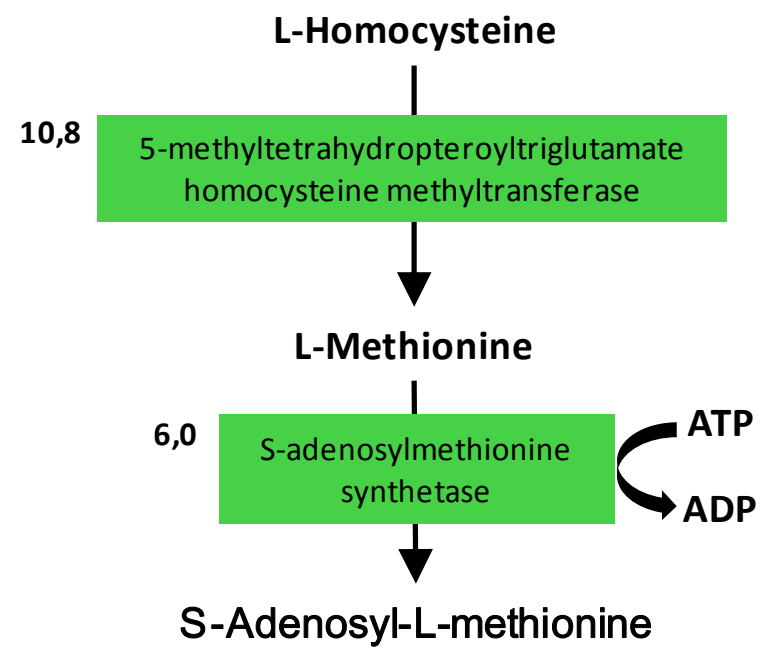

(SAM)

Figura 16: Genes responsáveis pela biossíntese de S-adenosil-metionina (SAM). Os números à esquerda das enzimas indicam o número de vezes que seus genes foram reprimidos no ponto $\mathrm{C} 0$ de hipóxia gradual.

Somente três genes relacionados ao metabolismo de aminoácidos tiveram perfis induzidos por hipóxia. Um deles codifica a enzima argininosuccinate synthase, responsável pela síntese de argininosuccinato a partir de citrulina e aspartato, uma reação limitante do ciclo da uréia. No entanto, com a descoberta do ciclo da citrulina-NO, esta enzima tem sido mostrada como um potencial passo limitante na síntese de óxido nítrico (NO) (Husson et al., 
2003). Foi demonstrado que NO é produzido em altos níveis, em hipóxia, por mitocôndrias de mamíferos (Schild et al., 2003; Valdez et al., 2004) e também de leveduras (Castello et al., 2006). Em leveduras também foi demonstrado que o NO produzido pelas mitocôndrias em hipóxia estimula a expressão do gene $C Y C 7$, um gene de hipóxia em leveduras, e também leva a um aumento da nitração de resíduos protéicos de tirosina, sugerindo em possível papel do NO na sinalização de hipóxia (Castello et al., 2006).

Outro gene com perfil induzido codifica a Delta-1-pyrroline-5-carboxylate dehydrogenase, enzima limitante para a biossíntese de prolina, a partir de glutamato. Também foi induzido o gene da enzima Glutamine synthetase, que sintetiza glutamina, condensando amônia a glutamato.

\subsubsection{Ciclo Celular}

Quatro genes codificando proteínas envolvidas com o ciclo celular foram induzidos por hipóxia. São duas septinas, uma proteína quinase dependente de ciclina (PHOB) e uma S-phase kinase-associated protein 1A. O gene codificando uma Cyclin-dependent kinase regulatory subunit foi reprimido. Esta regulação da expressão de genes envolvidos em ciclo celular está provavelmente relacionada às modificações morfológicas e no crescimento de $B$. emersonii, observadas quando o fungo está exposto ao estresse de hipóxia.

\subsubsection{Parede Celular}

Observa-se nesta categoria a indução de dois genes codificando quitinases (Chitinase e Chitinase Chi80 precursor) e um codificando uma quitina desacetilase (Chitin deacetylase). Enquanto as quitinases quebram as ligações glicosídicas, a quitina desacetilase hidrolisa os grupos $\mathrm{N}$-acetamida dos resíduos de $\mathrm{N}$-acetil-D-glicosamine deste polissacarídeo, resultando na provável digestão e reorganização da parede de quitina em $B$. 
emersonii. Adicionalmente, encontramos como reprimido um gene codificando uma quitina sintetase (Chitin synthase 1), reforçando ainda mais o efeito da digestão de quitina em hipóxia. Esta regulação da expressão de genes envolvidos com o metabolismo de quitina está provavelmente relacionada às modificações morfológicas de alongamento celular, observadas nas células de B. emersonii sob carência de oxigênio (seção 5.1.1).

\subsubsection{Estrutura de Cromatina}

Nesta categoria encontramos a repressão de três genes que codificam histonas (H2A, $\mathrm{H} 2 \mathrm{~B}$ e H3) e de dois genes relacionados à morte celular programada. Estes dois últimos representam mais um indício de que $B$. emersonii possui um mecanismo adaptativo de sobrevivência à falta de oxigênio.

\subsubsection{Metabolismo Energético}

Nas seções iniciais desta tese, o oxigênio foi destacado por seu papel fundamental no metabolismo energético de grande parte dos organismos, inclusive em anaeróbios facultativos como S. cerevisiae. Por este motivo, é de extrema importância que estes organismos tenham como modular e reprogramar as funções essenciais de seu metabolismo, de acordo com a disponibilidade de oxigênio. Em B. emersonii isso não parece ser diferente. Como veremos a seguir, este fungo modula a transcrição de vários genes relacionados ao metabolismo energético, redirecionando seu metabolismo aeróbico para o anaeróbico fermentativo.

Para facilitar a visualização dos genes de $B$. emersonii relacionados ao metabolismo energético afetados por hipóxia gradual e/ou direta foram construídas a Figura 17 que representa a via glicolítica e ciclo do ácido cítrico, e a Figura 18 que representa a cadeia respiratória. Como pode ser observado na Figura 17, grande parte dos genes que codificam 
enzimas da via glicolítica foram induzidos em hipóxia, ao passo que no ciclo do ácido cítrico, a maioria dos genes encontra-se reprimido ou não sofre alteração na expressão. Cabe salientar que as induções mais marcantes ocorreram justamente nas duas subunidades da fosfofrutokinase (PFK1 e PFK2), enzima que corresponde ao principal sítio de regulação da glicólise. Adicionalmente, também observamos uma forte indução do gene da lactato desidrogenase, enzima responsável pela reoxidação de NADH através da formação de lactato a partir de piruvato. Isso nos leva a crer que, pelo menos transcricionalmente, $B$. emersonii parece tentar direcionar seu metabolismo aeróbico para o anaeróbico fermentativo, sugerindo um exemplo do chamado "Efeito Pasteur". Na Tabela 3 observa-se também a forte indução de um gene que codifica a enzima álcool desidrogenase dependente de NADP+ (NADP-dependent alcohol dehydrogenase), mas esta enzima tem a mesma função que a álcool desidrogenase fermentativa dependente de $\mathrm{NAD}+$. Na verdade ela participa do metabolismo de alcoóis alifáticos.

Como mostrado na seção 5.1.6, alguns genes de enzimas da via glicolítica tiveram suas expressão analisada por qRT-PCR, pois não estavam presentes nas lâminas de microarranjos. Um desses genes corresponde a uma fosfofrutoquinase dependente de pirofosfato (pyrophosphate--fructose 6-phosphate 1-phosphotransferase) e foi bastante induzido por hipóxia. Este gene, descoberto em 1974 (Reeves et al., 1974) na ameba parasita Entamoeba histolytica, atua convertendo frutose-6-fosfato em frutose-1,6bisfosfato, utilizando pirofosfato inorgânico, ao invés de ATP, como fazem normalmente as fosfofrutoquinases dependentes de ATP. Com isso, a via glicolítica acaba economizando um ATP por mol de glicose, ficando com um saldo de 3 ATP, ao invés de 2. Esta enzima já foi descrita em diversos organismos como bactérias, protistas e até plantas superiores (Mertens, 1991), no entanto, até o momento não foi descrita em nenhum outro fungo (fonte: KEGGKyoto Encyclopedia of Genes and Genomes). Curiosamente, verificou-se que a atividade da 
PPi-PFK em sementes de arroz (Oryza sativa) submetidas à hipóxia aumenta consideravelmente, sugerindo a utilização a PPi-PFK ao invés da PFK normal em plantas superiores em condições de hipóxia, o que poderia aumentar em até $50 \%$ o rendimento de ATP da glicólise, graças ao uso do pirofosfato inorgânico como doador de fosfato (Mertens et al., 1990). 


\section{Hipóxia}

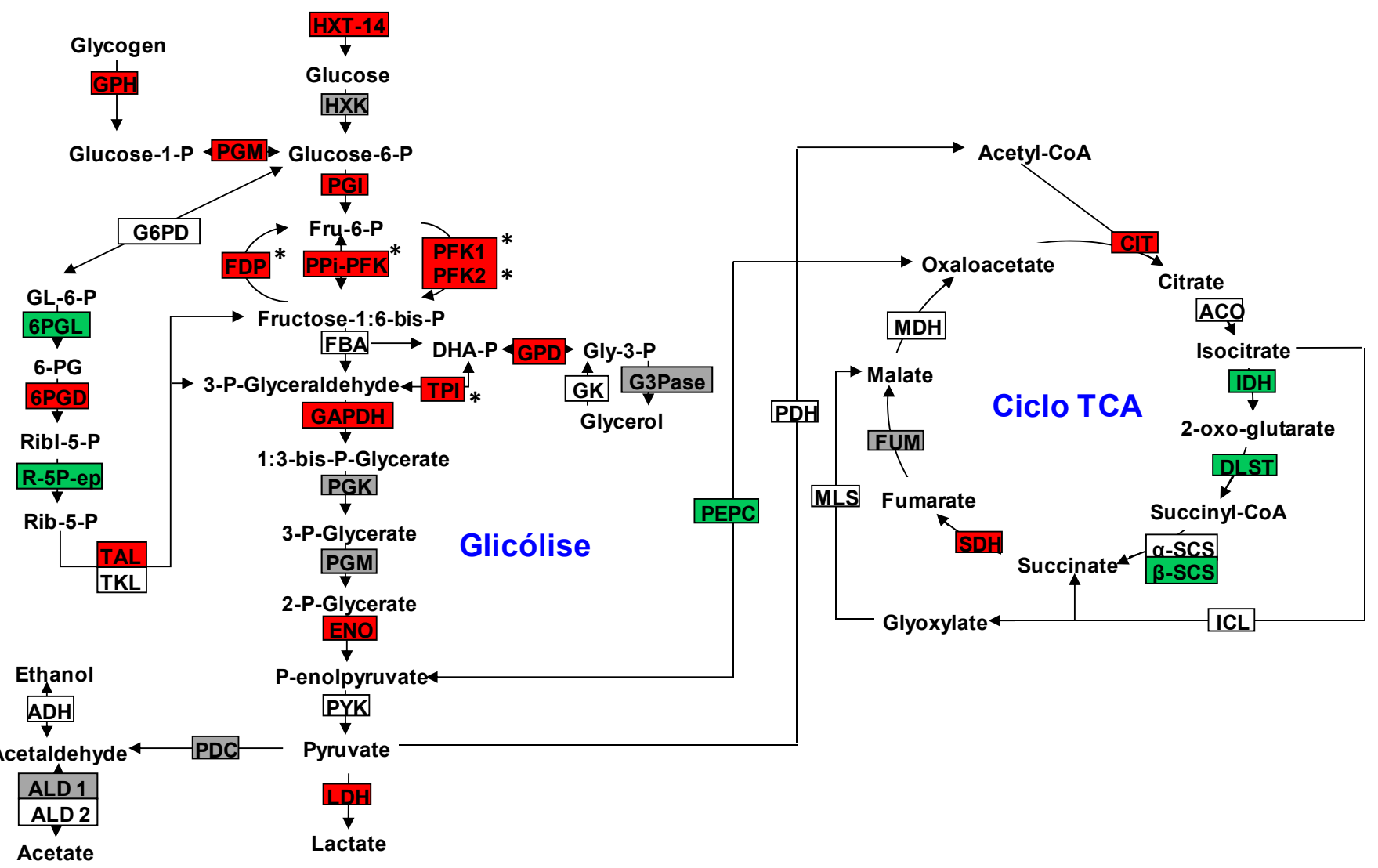

GPH: Glicogênio fosforilase PGM: fosfoglicomutase

PK: piruvato kinase

PEPC: fosfoenolpiruvato carboxikinase

PYC: piruvato carrboxilase

PDH: piruvato desidrogenase

PDC: piruvato decarboxilase

ADH: alcool desidrogenase

ALD1/2: aldeido desidrogenase

ACS: acetil CoA sintase

G6PD: glicose 6P desidrogenase

6PGL: 6 fosfoglucolactonase

6PGD: 6 fosfogluconato desidrogenase

R-5P-ep: ribose 5 -fosfato epimerase

TAL: transaldolase

TKL: transcetolase
GPD: glicerol 3P desidrogenase

GK: glicerol kinase

G3Pase: glicerol 3 fosfatase

CIT: citrato sintase

ACO: aconitase

IDH: isocitrato desidrogenase

$\mathrm{KDH}$ : alfa cetoglutarato desidrogenase

SCS: succinil CoA sintase

SDH: succinato desidrogenase

FUM: fumarase

MDH: malato desidrogenase

MLS: malato sintase

ICL: isocitrato liase

Figura 17: Expressão dos genes codificando enzimas do metabolismo energético central de B. emersonii em hipóxia gradual e/ou direta. Os genes induzidos, reprimidos e não afetados estão em vermelho, verde e branco, respectivamente. Genes ainda não seqüenciados em $B$. emersonii estão em cinza. Genes marcados com * indicam que foram analisados por qRTPCR, pois não estavam presentes nas lâminas do microarranjo. Os níveis de indução ou repressão de cada gene podem ser acessados na Tabela 3, ou na seção 5.1.6, no caso dos genes marcados com*. 
Na Figura 18, a seguir, pode-se observar que a fosforilação oxidativa também é transcricionalmente afetada, ao menos em parte, por hipóxia. Ao que parece, existe certa tendência à repressão desses genes. Foram reprimidos os genes de duas subunidades do complexo V (ATP sintase), o gene do citocromo C (cerca de três vezes) e o gene codificando uma das subunidades do complexo I (NADH ubiquinona oxidoredutase). Dois genes foram induzidos, codificando a subunidade 5 do complexo IV (COX-5) e uma subunidade de $12 \mathrm{kDa}$ do complexo succinato desidrogenase.

\section{Hipóxia}

\section{Fosforilação Oxidativa}

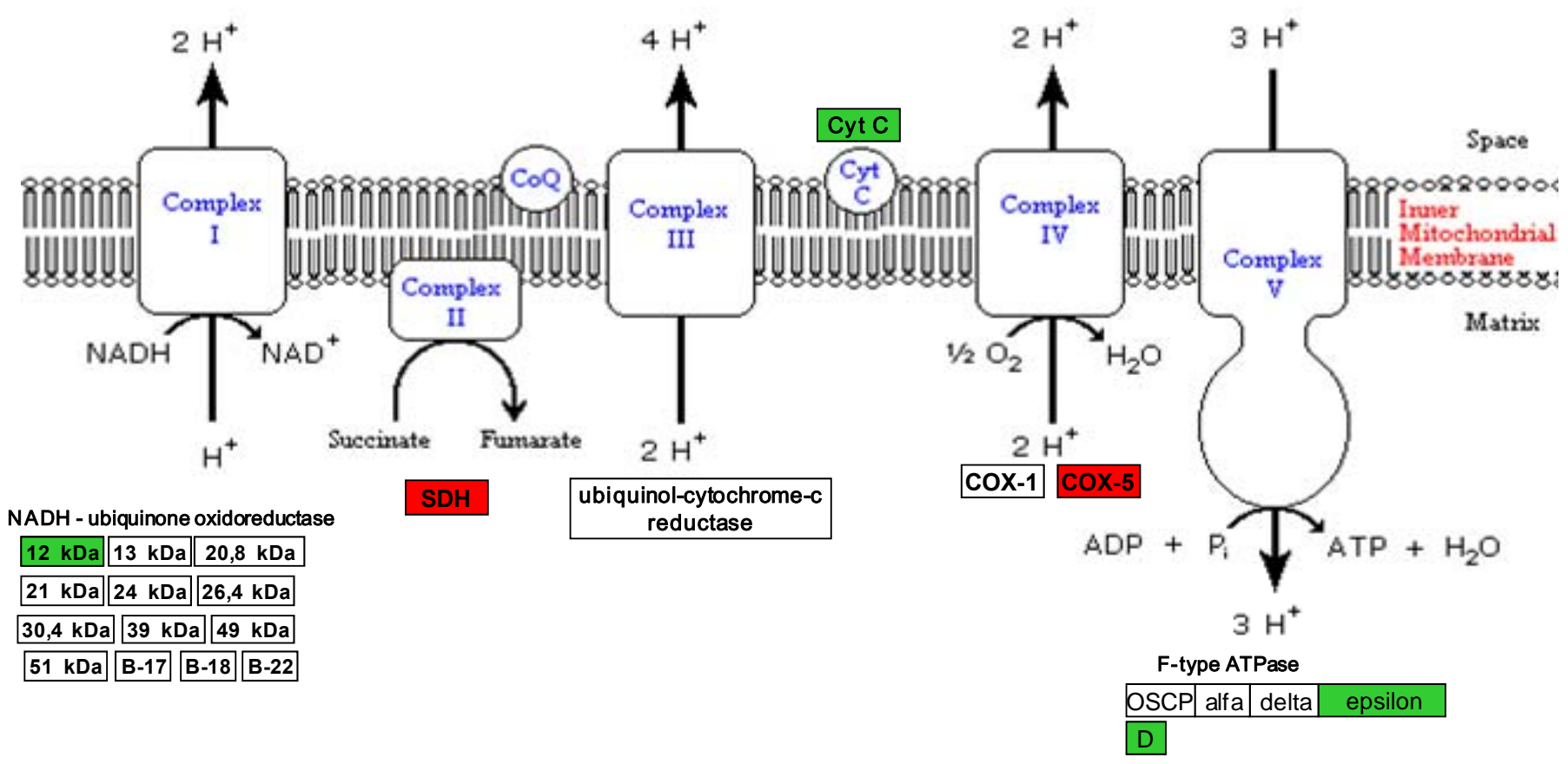

Figura 18: Expressão gênica de enzimas da cadeia respiratória de B. emersonii em hipóxia gradual e/ou direta. Os genes induzidos, reprimidos e não afetados estão em vermelho, verde e branco, respectivamente. 
Outro gene fortemente induzido em hipóxia é o que codifica uma anidrase carbônica (carbonic anhydrase protein) (Tabela 3). Esta enzima é responsável pela rápida conversão de dióxido de carbono $\left(\mathrm{CO}_{2}\right)$ em bicarbonato e prótons, como mostra a reação a seguir:

$$
\begin{gathered}
\mathrm{AC} \\
\mathrm{CO}_{2}+\mathrm{H}_{2} \mathrm{O} \Leftrightarrow \mathrm{H}_{2} \mathrm{CO}_{3} \Leftrightarrow \mathrm{HCO}_{3}^{-}+\mathrm{H}^{+}
\end{gathered}
$$

Além de outras funções fisiológicas, as anidrases carbônicas geralmente estão relacionadas à homeostase de $\mathrm{CO}_{2}$ e pH, controlando as acidoses metabólicas e respiratórias. Entretanto, não há relatos sobre a indução de anidrases carbônicas por hipóxia em outros fungos. Uma provável função desta anidrase carbônica induzida em $B$. emersonii seria combater uma possível acidose causada pela fermentação láctica.

Em mamíferos, a anidrase carbônica IX (CAIX) é um dos principais alvos do fator HIF-1 $\alpha$ e, por isso, é bastante induzida em hipóxia. CAIX vem sendo correlacionada com a progressão e invasibilidade tumoral e, por ser uma anidrase carbônica de membrana, tem se demonstrado que ela participa do controle de acidose intracelular e da acidificação do ambiente tumoral extracelular (Winum et al., 2008).

Outro grupo de genes que merece destaque, corresponde a quatro subunidades da $\left(\mathrm{H}^{+}\right)$ATPase vacuolar, que foram induzidos em hipóxia (Tabela 3). Este tipo de $\left(\mathrm{H}^{+}\right)$ATPases, também chamada de V-ATPase, atua como uma bomba de prótons dependente de ATP, que têm a função tanto de acidificar compartimentos intracelulares, quanto transportar prótons através da membrana plasmática (Jefferies et al., 2008). Esta regulação, em B. emersonii, também pode estar relacionada com uma provável acidificação intracelular causada pela fermentação láctica. 


\subsubsection{Metabolismo de Lipídeos}

Esta categoria merece especial atenção, pois a própria síntese de ergosterol e ácidos graxos é dependente de oxigênio. Como pode ser observado na Tabela $\mathbf{3}$, a carência de oxigênio levou à indução significativa de vários genes relacionados ao metabolismo de lipídeos, assim como foi observado em Saccharomyces cerevisiae (Becerra et al., 2002; Kwast et al., 1999; ter Linde et al., 1999), Schizosaccharomyces pombe (Todd et al., 2006) e Candida albicans (Setiadi et al., 2006) e Cryptococcus neoformans (Chun et al., 2007).

Um dos genes fortemente induzidos é o que codifica a $\Delta-9$ ácido graxo desaturase, que corresponde ao gene OLE1 de Saccharomyces cerevisiae. Esta enzima tem a função de formar os ácidos graxos monoinsaturados palmitoleico (16:1) e oleico (18:1), a partir de palmitoil (16:0) ou estearoil (18:0) coenzima A (Ntambi, 1999), adicionando uma dupla ligação entre os carbonos C9 e C10, utilizando oxigênio molecular (Figura 19). Tais ácidos graxos insaturados são essenciais para manter a fluidez e expansão da membrana citoplasmática. Em S. cerevisiae, proporção de ácidos graxos insaturados incorporados à membrana, está relacionada à tolerância a etanol, choque térmico e movimento e herança mitocondrial (Alexandre et al., 1994; Carratu et al., 1996; Stewart and Yaffe, 1991), mostrando que a regulação da expressão deste gene tem importância fisiológica em situações de estresse. Adicionalmente, outro gene interessante, complementar ao da $\Delta-9$ ácido graxo desaturase e também bastante induzido por hipóxia, é o que codifica a enzima cyclopropane-fatty-acyl-phospholipid synthase (CFA sintase). Esta enzima atua adicionando um anel ciclopropano em duplas ligações de fosfolipídeos, utilizando S-adenosil metionina (SAM) como doador de grupo metila (Figura 19), favorecendo também a fluidez da membrana e protegendo os fosfolipídeos de ataques por algumas espécies reativas de oxigênio (Cronan, 2002). 


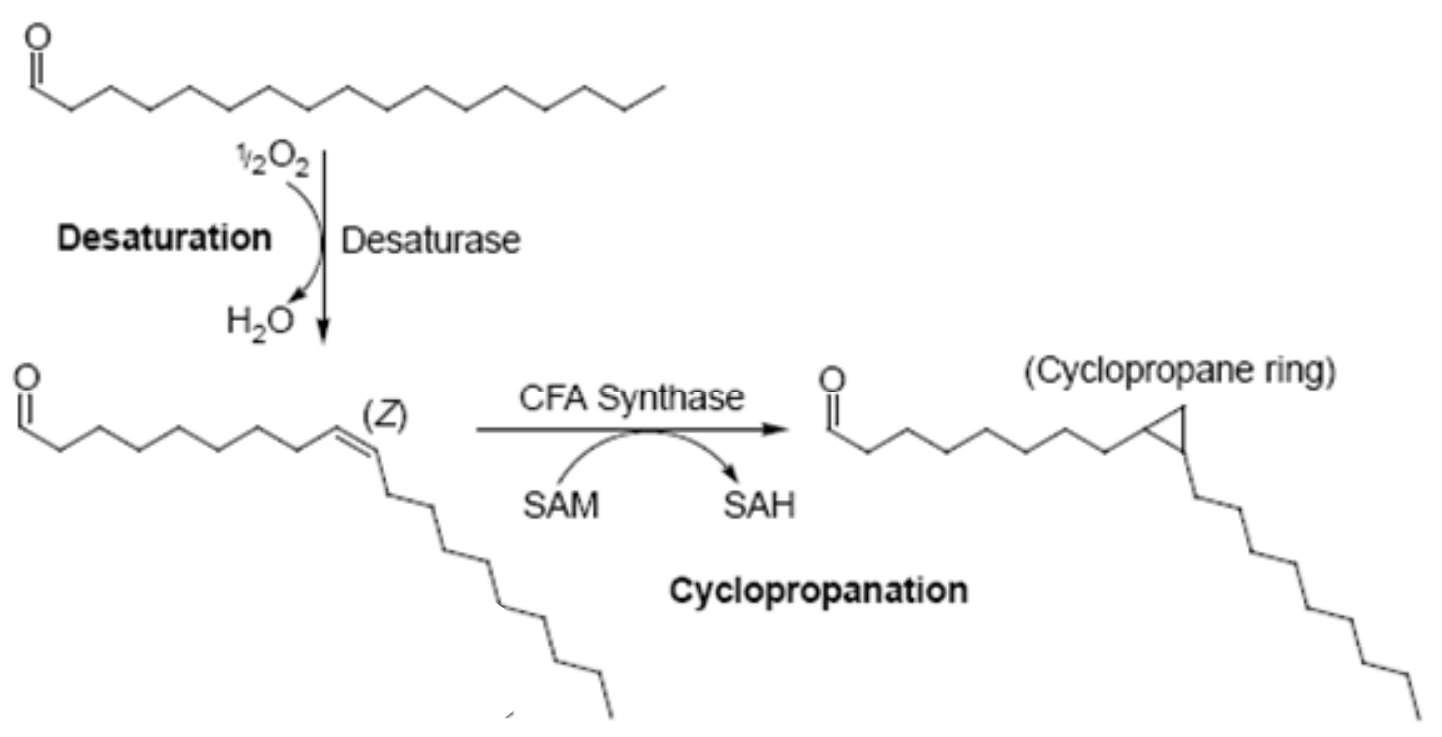

Figura 19: Esquema das modificações de lipídeos promovidas pelas enzimas $\Delta-9$ Ácido graxo desaturase e CFA sintase (Adaptado de Cronan, 2002).

O curioso é que embora o gene da enzima CFA sintase esteja muito induzido em hipóxia, dois principais genes responsáveis pela biossíntese de S-adenosil metionina (SAM) estão fortemente reprimidos nesta condição (ver Metabolismo de aminoácidos na seção 5.1.7.2). Como foi dito anteriormente, além de S-adenosil metionina requerer ATP em sua síntese, ela participa de diversos processos biossintéticos nas células e, por esta razão, é totalmente conveniente que sua síntese seja diminuída em hipóxia. Por outro lado, como o processo de adição de anéis ciclopropano em fosfolipídeos parece ser importante para a adaptação de B. emersonii ao estresse de hipóxia e, por isso, a expressão do gene da CFA sintase é fortemente aumentada, talvez na tentativa de suprir a falta de SAM disponível.

Também foram induzidos os genes codificando as enzimas C-4 methyl sterol oxidase, C-5 sterol desaturase e fatty acid-2 hydroxylase, que em Cryptococcus neoformans (Chang et al., 2007) e Schizosaccharomyces pombe (Todd et al., 2006), são alvos do ortólogo do fator SREBP de mamíferos (seção 2.2). Estes ortólogos têm mostrado um papel 
central na adaptação destes fungos ao crescimento em hipóxia (Hughes et al., 2005; Todd et $a l .$, 2006).

Além destes genes, vários outros relacionados com processos biossintéticos de lipídeos também foram induzidos por hipóxia, como fatty acid synthase, delta 4-(E)sphingolipid desaturase, 1-acylglycerol-3-phosphate acyltransferase e phosphatidylserine decarboxylase. Interessantemente, os únicos genes reprimidos foram duas Enoyl coenzyme A hydratases, que são enzimas responsáveis por metabolizar ácidos graxos produzindo Acetil-CoA e energia. Visto que as moléculas de Acetil-CoA não poderão ser eficientemente oxidadas pelo ciclo de Krebs, devido à falta de oxigênio, faz todo sentido estes genes estarem reprimidos.

\subsubsection{Homeostase Redox}

Muito tem sido descoberto a respeito da resposta transcricional a hipóxia e os mecanismos sensores de oxigênio tanto em mamíferos quanto em leveduras (seção 2.2). Entretanto, a natureza dos sinais através dos quais as células detectam o oxigênio presente, ainda não foi totalmente elucidada. Tem sido proposto que no sistema HIF-1 de mamíferos, as espécies reativas de oxigênio (ROS) geradas na mitocôndria em condições de hipóxia podem aumentar a proporção $\mathrm{Fe}^{3+} / \mathrm{Fe}^{2+}$ via reação de Fenton, diminuindo, assim, a ação das prolil-hidroxilases, o que leva à estabilização de HIF-1 $\alpha$ (Taylor, 2008). O mesmo tem sido proposto para Saccharomyces cerevisiae, apesar de essas leveduras não possuírem o fator HIF. Foi demonstrado que o complexo III mitocondrial de leveduras é necessário para o aumento da produção de ROS mitocondrial e para a expressão de um grupo de genes induzíveis por hipóxia, indicando que a formação de ROS poderia ter um papel na indução da expressão destes genes (Guzy et al., 2007). A formação de ROS mitocondrial em hipóxia ainda tem sido tema de discussão em diversos trabalhos e ainda não foi completamente 
elucidada devido às dificuldades metodológicas de medir essas espécies. Ao que parece, a formação de ROS em hipóxia é limitada à mitocôndria e, por isso, não conferem um estresse oxidativo propriamente dito.

Em B. emersonii, podemos observar que certos genes relacionados a resposta a estresse oxidativo foram induzidos por hipóxia (Tabela 3). Estes genes codificam enzimas como Glutationa-S-transferase (GST), Glutationa peroxidase, Peroxiredoxina e proteínas com domínios Piridoxamina e Tioredoxina. Essa resposta nos levaria a crer que de fato existe um estresse oxidativo ocorrendo em B. emersonii submetida à hipóxia. No entanto, foram também reprimidos alguns genes relacionados a este tipo de estresse, como Glutationa redutase, Superoxido dismutase $(\mathrm{Cu}-\mathrm{Zn})$, Tioredoxina peroxidase, Glutationa-S-transferase microssomal e uma proteína relacionada à biossíntese de Piridoxina. Provavelmente estes genes foram reprimidos em hipóxia, pois a falta de oxigênio molecular intuitivamente levaria à diminuição da formação de suas espécies reativas, mas o fato de encontrarmos alguns genes induzidos nos leva a pensar que neste fungo também possa estar havendo a produção de ROS em hipóxia.

\subsubsection{Proteínas Ribossômicas / Tradução}

Como se sabe, a síntese protéica, juntamente com o transporte iônico por membranas, está entre os processos mais dispendiosos em energia para as células. Em condições de hipóxia, fica claro, como foi dito na seção 2.1, que o aproveitamento dos nutrientes para produção de energia é menor do que na presença de oxigênio. Desta maneira, uma das adaptações dos organismos, principalmente daqueles tolerantes à carência de oxigênio, é a economia de energia. Em B. emersonii, isso não parece ser diferente, pois a categoria Proteínas Ribossômicas / Tradução se destacou como uma das funções celulares com maior numero de genes reprimidos por hipóxia (Figura 15). 
Podemos observar (Tabela 3) que foram reprimidos diversos genes relacionados a subunidades ribossômicas, fatores de iniciação de tradução e síntese de tRNAs. Dentre os poucos induzidos estão quatro fatores de elongação da tradução. Tal comportamento de inibição de síntese protéica em hipóxia também pode ser observado em células humanas (Connolly et al., 2006) e em fungos como Cryptococcus neoformans (Chun et al., 2007).

\subsubsection{Resposta a Estresse}

Nesta categoria encontramos a forte indução do gene codificando a proteína de choque térmico mitocondrial Hsp70-9 (Georg Rde and Gomes, 2007). Foi mostrado recentemente que hipóxia constante induz da expressão dos genes que codificam as proteínas de choque térmico Hsp70 e Hsp23 em Drosophila melanogaster, e que essa indução é responsável por um aumento significativo na sobrevivência das moscas (Azad et al., 2009). Em células de mamíferos, foi demonstrado que a indução de Hsp70 em hipóxia é dependente do fator HIF-1 e que esta chaperona possui um importante papel protetor contra o estresse de hipóxia tanto em células tumorais (Huang et al., 2009; Tikhonova et al., 2008), quanto em células renais, neurônios e até em células-tronco mesenquimais (Bidmon et al., 2000; Chang et al., 2009; Lu et al., 2002; Papadopoulos et al., 1996; Plumier et al., 1997; Rajdev et al., 2000; Vicencio et al., 2003). A indução de Hsp70 por hipóxia também foi relatada em fungos como Candida albicans (Setiadi et al., 2006) e Cryptococcus neoformans (Chun et al., 2007).

Por outro lado, a hipóxia levou à repressão de dois genes de proteínas de choque térmico: uma Hsp mitocondrial de $10 \mathrm{kD}$ e a Hsp70-3. Esta última corresponde à Hsp70 constitutiva de $B$. emersonii e não se mostrou induzida nem mesmo em choque térmico (Georg Rde and Gomes, 2007). 


\subsubsection{Estrutura Celular / Microtúbulos}

Como pode ser observado na Tabela 3, esta categoria apresentou três genes reprimidos e nove induzidos por hipóxia. Estes transcritos codificam proteínas que compõem cadeias de actina, miosina, tubulina, dineína, calponina e trangelina. Como se sabe, tais proteínas estão entre os componentes mais importantes do citoesqueleto. Elas estão envolvidas em vários processos biológicos como mudanças de forma, crescimento, mobilidade, secreção, divisão e diferenciação (Cleveland and Sullivan, 1985; Farmer et al., 1986). Provavelmente, este tipo de regulação deve estar associado às modificações morfológicas observadas nas células de $B$. emersonii submetidas à hipóxia.

O gene codificando a proteína calponina/trangelina, que foi encontrado induzido em hipóxia, apresenta na levedura Saccharomyces cerevisiae, uma função de estabilização de filamentos de actina contra desmontagem da cadeia (Goodman et al., 2003). Em humanos, o gene da trangelina apresentou-se induzido em tecido muscular liso arterial pulmonar submetido à hipóxia, mas de maneira independente do fator HIF-1 (Zhang et al., 2009).

\subsubsection{Transcrição / Processamento de RNA}

Acompanhando a repressão dos genes relacionados à síntese protéica (seção 5.1.7.9), a categoria de Transcrição / Processamento de RNA também foi marcada por uma regulação negativa sob hipóxia, com destaque para RNA helicases e diversas subunidades de RNA polimerases.

\subsubsection{Transporte}

O transporte por membrana, como foi dito anteriormente, é um processo bastante dispendioso em energia para as células. Por isso, é perfeitamente plausível uma regulação negativa de genes relacionados a esta categoria, quando em condições de hipóxia. A Tabela 
3 mostra que diversos genes que codificam transportadores foram reprimidos. Um desses genes codifica uma ADP/ATP translocase, que transporta ATP para fora da matriz mitocondrial e ADP para dentro. Sua repressão faz sentido, pois na falta de oxigênio a quantidade de ATP produzida pela cadeia respiratória é drasticamente diminuída. Também foram reprimidos genes de transportadores de aminoácidos, além de dois transportadores do tipo $\mathrm{ABC}$, conhecidos pela translocação de diversos substratos contra gradientes de concentração, através da hidrólise de ATP (Higgins, 1992). Observamos também forte repressão de um gene codificando um transportador de glutationa de alta afinidade.

Não encontramos, entretanto, somente genes reprimidos. Observamos também a indução de diversos transportadores que devem ser importantes para a adaptação à carência de oxigênio. Um deles é o transportador de glicose HXT14. Sua indução é totalmente favorável para uma célula que, como dissemos anteriormente, está privilegiando o metabolismo anaeróbico de glicose. Além deste, também destacamos como induzidos, genes de transportadores de nicotinamida mononucleotídeo, metionina, e ácidos tricarboxílicos.

\subsubsection{Comparação da resposta transcricional de B. emersonii com a de outros fungos}

Comparando nossos dados com a resposta transcricional de outros fungos ao estresse de hipóxia, disponível na literatura, pudemos observar que B. emersonii representa um modelo de estudo bastante peculiar para este tipo de estresse.

A partir de dados disponíveis para Trichoderma reesei (Bonaccorsi et al., 2006) ou Cryptococcus neoformans (Chun et al., 2007) observamos certas semelhanças marcantes como a repressão de um número significativo de genes relacionados à síntese protéica (incluindo proteínas ribossômicas) e a indução de genes relacionados ao metabolismo de lipídeos e síntese de esteróis, além de genes de resposta a estresse. No entanto, a principal diferença encontrada em $B$. emersonii, em relação a esses fungos, consiste no metabolismo 
energético. Como relatado nesta tese, em hipóxia, B. emersonii favorece o metabolismo anaeróbico. Isso se verificou pela indução de genes que codificam enzimas da via glicolítica e lactato desidrogenase, ao passo que em relação ao ciclo do ácido cítrico, a maioria dos genes encontram-se reprimido ou não sofrem alteração na expressão, o que sugere um "Efeito Pasteur" (ver Figura 17).

Em Cryptococcus neoformans, o metabolismo energético parece não sofrer regulação transcricional significante em hipóxia (Chun et al., 2007). Por sua vez, em Trichoderma reesei ocorre diminuição na produção de ATP, como resultado de uma drástica repressão da transcrição da maioria dos genes codificando enzimas da via glicolítica e do ciclo do ácido cítrico (Chun et al., 2007). Desta forma, a resposta B. emersonii parece assemelhar-se mais à resposta de Saccharomyces cerevisiae, pois nessa levedura já foi demonstrado que a carência de oxigênio leva a um re-direcionamento metabólico de aerobiose para anaerobiose (fermentação) devido a uma forte indução de genes responsáveis pelo metabolismo anaeróbico (Kwast et al., 2002). Este re-direcionamento metabólico também pode ser observado em células de mamíferos submetidas à hipóxia (Helmlinger et al., 1997; Vogt et al., 2001), sendo então por esta razão a levedura Saccharomyces cerevisiae estudada como modelo de resposta à privação de oxigênio. No entanto, nossos resultados mostram que $B$. emersonii seria um modelo mais conveniente, pois o fato de $S$. cerevisiae ser um organismo anaeróbico facultativo limita sua comparação com mamíferos.

\subsubsection{Validação dos Microarranjos de cDNA}

\subsubsection{Hipóxia Gradual}

Para validarmos os dados de microarranjo de cDNA de hipóxia gradual realizamos experimentos de RT-PCR quantitativo (qRT-PCR) para 6 genes, sendo 3 com perfis de indução e 3 com perfis de repressão, utilizando duas réplicas biológicas independentes. As 
sequencias dos oligonucleotídeos utilizados nos experimentos de qRT-PCR estão mostradas na Tabela 1 (seção 4.13). Como normalizador, foi utilizado o gene BeE60H30A07, que codifica uma heat shock protein $90 \mathrm{kDa}$. Este normalizador foi escolhido, pois sua expressão não variou nos microarranjos de hipóxia gradual. Como pode ser observado na Figura 20, a seguir, a comparação direta entre as duas metodologias mostra que elas foram qualitativamente coincidentes, o que valida os resultados obtidos no microarranjo. 


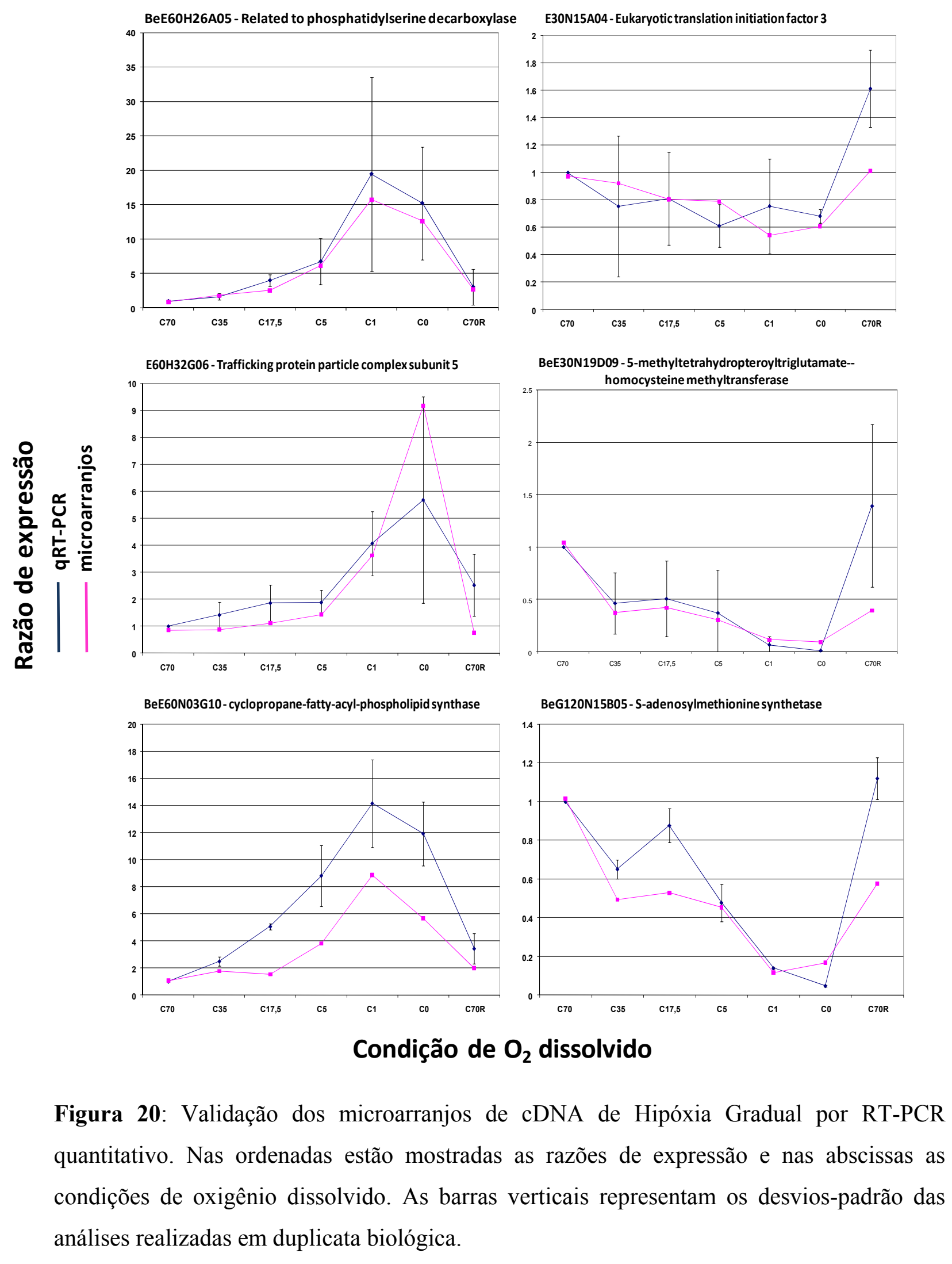

Condição de $\mathrm{O}_{2}$ dissolvido

Figura 20: Validação dos microarranjos de cDNA de Hipóxia Gradual por RT-PCR quantitativo. Nas ordenadas estão mostradas as razões de expressão e nas abscissas as 


\subsubsection{Hipóxia Direta}

Realizamos também a validação do experimento de hipóxia direta com experimentos de RT-PCR quantitativo (qRT-PCR) para 4 genes, utilizando duas réplicas biológicas independentes. As sequencias dos oligonucleotídeos utilizados estão mostradas na Tabela 1 (seção 4.13). Como normalizador, também foi utilizado o gene BeE60H30A07, assim como na validação de hipóxia gradual. Como pode ser observado na Figura 21, a seguir, a comparação direta entre as duas metodologias mostra que elas foram qualitativamente coincidentes, o que valida os resultados obtidos no microarranjo.
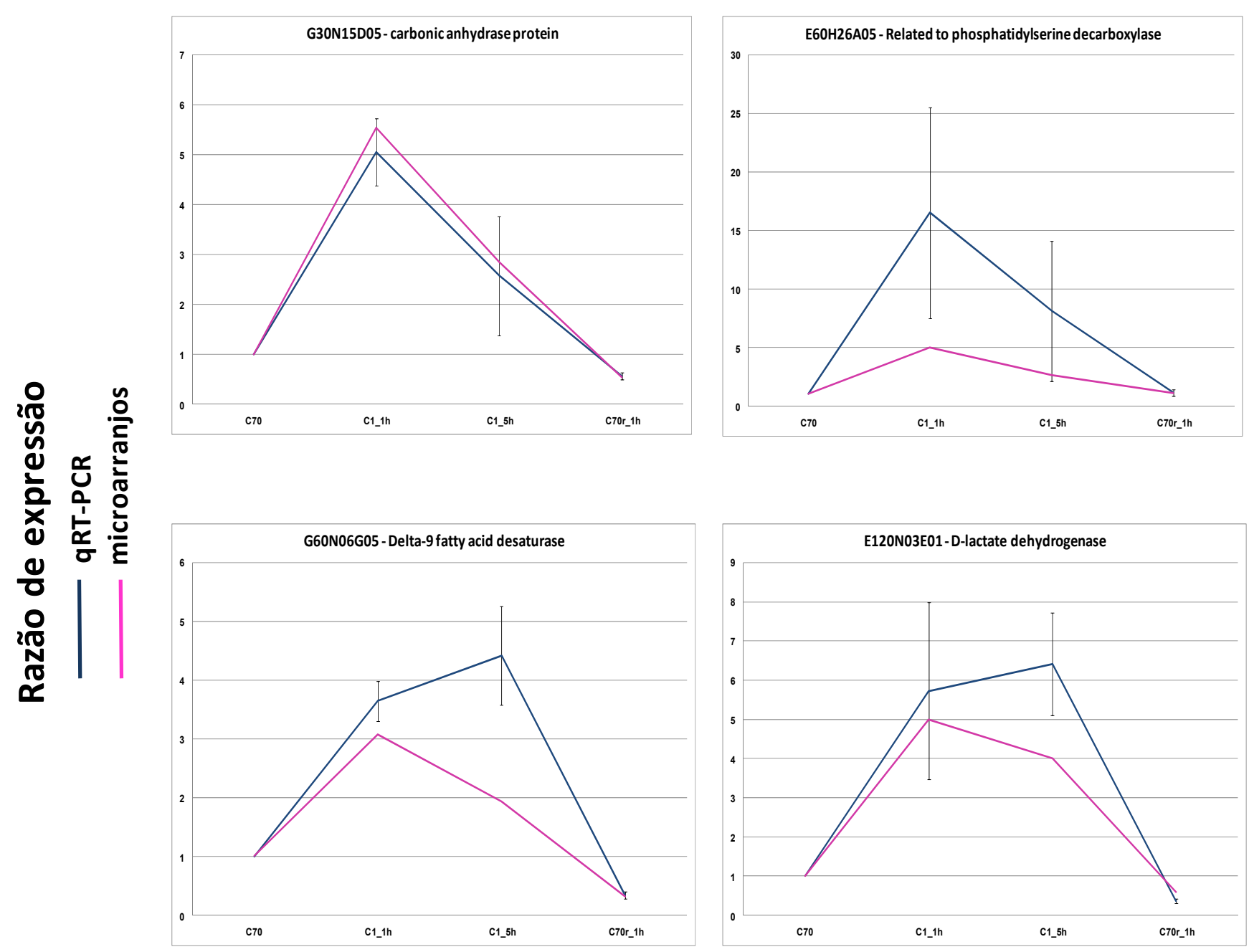

\section{Condição de $\mathrm{O}_{2}$ dissolvido}

Figura 21: Validação dos microarranjos de cDNA de Hipóxia Direta por RT-PCR quantitativo. Nas ordenadas estão mostradas as razões de expressão e nas abscissas as 
condições de oxigênio dissolvido. As barras verticais representam os desvios-padrão das análises realizadas em duplicata biológica.

\subsection{Análise metabolômica em hipóxia por Eletroforese Capilar}

\subsubsection{Preparação das Amostras}

B. emersonii foi cultivada nas mesmas condições do experimento de hipóxia gradual (seção 4.6) e foram retiradas alíquotas de normóxia (C70), anóxia $(\mathrm{C} 0)$ e reoxigenação (C70r). Para conseguirmos uma quantidade razoável de metabólitos para os experimentos de eletroforese capilar, foi necessário realizar um experimento para cada ponto analisado (C70, C0 e C70r) e retirar toda a massa de células para a preparação dos extratos. Como cada ponto foi feito em triplicata biológica, realizamos 9 experimentos no total, para a análise dos metabólitos catiônicos.

\subsubsection{Quantificação de proteínas totais}

Para podermos igualar as diluições dos extratos metabólicos de B. emersonii, de acordo com a concentração de proteínas totais, quantificamos as proteínas totais dos extratos pelo método de Bradford, antes da filtragem que elimina proteínas (seção 4.14.3).

Primeiramente foi construída uma curva-padrão de BSA, através da qual a concentração de proteína nos extratos foi calculada (Tabela 4). As amostras foram nomeadas de acordo com a condição de oxigênio dissolvido (C70, $\mathrm{C} 0$ ou $\mathrm{C} 70 \mathrm{r})$, com a réplica biológica (numeradas de 1 a 3). O volume final de solubilização foi calculado de modo a manter iguais as concentrações de proteínas nas amostras. 
Tabela 4: Quantificação de proteínas totais nos extratos metabólicos de B. emersonii. As amostras foram nomeadas de acordo com a condição de oxigênio dissolvido (C70, C0 ou C70r), com a réplica biológica (numeradas de 1 a 3). O volume final de solubilização foi calculado de modo a manter iguais as concentrações de proteínas nas amostras.

\begin{tabular}{|c|c|c|c|}
\hline Amostra & $\begin{array}{c}\text { proteínas } \\
\text { totais } \\
(\mu \mathrm{g} / \mu \mathrm{L})\end{array}$ & $\begin{array}{c}\text { volume } \\
\text { para } \\
\text { solubilizar } \\
\text { (uL) }\end{array}$ & $\begin{array}{c}\text { conc. final } \\
\text { proteínas } \\
(\mu \mathrm{g} / \mu \mathrm{L})\end{array}$ \\
\hline $\mathrm{C} 70-1$ & 0.0951 & 189.68 & 1.55 \\
$\mathrm{C} 70-2$ & 0.0876 & 174.79 & 1.55 \\
$\mathrm{C} 70-3$ & 0.0853 & 170.20 & 1.55 \\
$\mathrm{CO}-1$ & 0.0894 & 178.22 & 1.55 \\
$\mathrm{CO}-2$ & 0.0501 & 100.00 & 1.55 \\
CO-3 & 0.0968 & 193.12 & 1.55 \\
$\mathrm{C} 70 \mathrm{r}-1$ & 0.1141 & 227.51 & 1.55 \\
C7Or-2 & 0.1124 & 224.07 & 1.55 \\
C7Or-3 & 0.1371 & 271.59 & 1.55 \\
\hline
\end{tabular}

\subsubsection{Análise de metabólitos catiônicos por CE-MS}

Nesta análise foi possível identificar 18 metabólitos catiônicos de B. emersonii, sendo 17 aminoácidos e glutationa total. Alguns aminoácidos como Leucina/Isoleucina e Glutamina/Lisina possuem massas muito próximas e, por isso, foram analisados em conjunto. Não foi possível obter a concentração absoluta desses metabólitos nas amostras, mas sim uma quantificação relativa a um padrão interno de triptofano mascado com dois carbonos ${ }^{13} \mathrm{C}$, que foi adicionado às amostras na concentração de $0,04 \mathrm{mg} / \mathrm{ml}$, antes das análises.

Devido à complexidade das vias do metabolismo de aminoácidos, fica difícil correlacionar a regulação da expressão dos genes que codificam enzimas do metabolismo de aminoácidos com as variações nas concentrações intracelulares destas moléculas. No entanto, tentaremos tecer algumas considerações. Como se pode observar na Figura 22, tentamos comparar as áreas relativas dos aminoácidos em três pontos do experimento de hipóxia gradual: normóxia (C70), anóxia $(\mathrm{C} 0)$ e reoxigenação (C70r). 
Não houve variação significativa na concentração de quatro aminoácidos (metionina, prolina, fenilalanina e triptofano). Já os aminoácidos glutamato e aspartato tiveram suas concentrações intracelulares ligeiramente diminuídas por hipóxia, seguidas de uma recuperação na reoxigenação. Como foi observado na seção 5.1.7.2, o gene da enzima glutamato desidrogenase 3 está reprimido em condições de hipóxia e, por esta razão seria intuitivo dizer que o glutamato deveria se acumular. Por outro lado, também foi observada a indução dos genes da delta-1-pirrolina-5-carboxilato desidrogenase e da glutamina sintetase, enzimas que utilizam glutamato para a síntese de prolina e glutamina, respectivamente, condizendo com a diminuição da concentração de glutamato nas células.

Os aminoácidos leucina/isoleucina, asparagina, tirosina e cisteína apresentaram um acúmulo nas células submetidas à hipóxia. Se observarmos os dados de microarranjos dos genes responsáveis pela biossíntese leucina (2-isopropilmalato sintase e acetolactato sintase Ilv2), isoleucina (acetolactato sintase Ilv2) e cisteína (cisteína sintase) (seção 5.1.7.2), vemos que eles apresentam-se reprimidos em condições de hipóxia. Provavelmente a repressão destes genes se deve a um mecanismo de "feedback" negativo causado pelo acúmulo dos aminoácidos em hipóxia.

As análises do metabólitos aniônicos, que compreendem os intermediários da via glicolítica e ciclo do ácido cítrico, que ainda estão sendo finalizadas e não puderam ser incluídas nesta tese, serão fundamentais para o entendimento mais profundo do redirecionamento metabólico de B. emersonii em condições de hipóxia. 


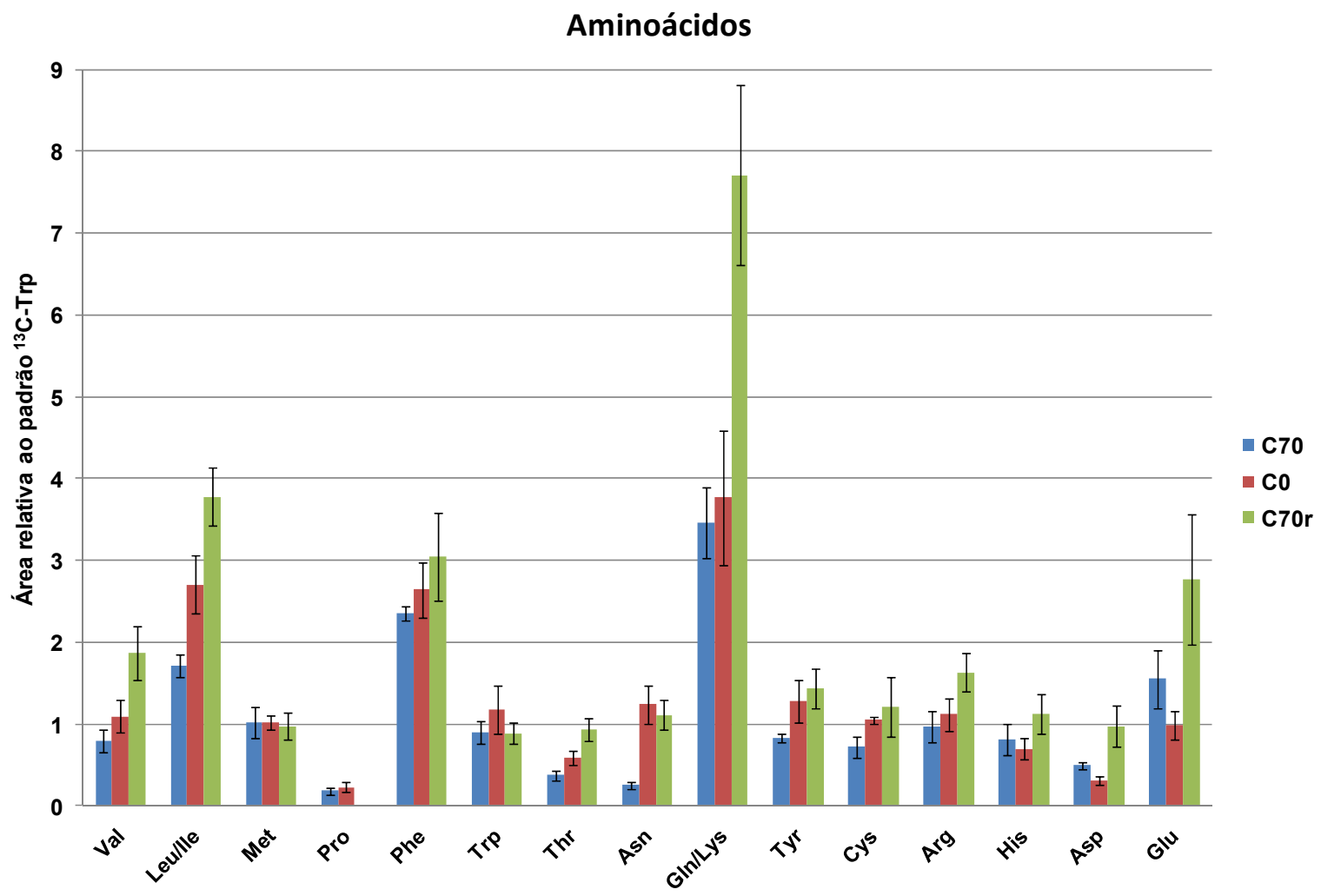

Figura 22: Análise de aminoácidos livres intracelulares por CE-MS. Os resultados são expressos como área do pico relativa ao padrão interno de Triptofano marcado com dois carbonos isótopos $\left({ }^{13} \mathrm{C}\right.$-Trp). As amostras proveem de experimentos de hipóxia gradual (seção 4.6) em que foram retiradas alíquotas de normóxia (C70), anóxia $(\mathrm{C} 0)$ e reoxigenação (C70r).

\subsection{Carência de Ferro (II)}

\subsubsection{Análise dos genes cuja expressão é afetada pela carência de ferro (II)}

Como já foi dito anteriormente, sabe-se que quelantes de ferro (II) como 2,2'dipyridyl, são conhecidos agentes mimetizadores de hipóxia através da estabilização de HIF$1 \alpha$ (Semenza, 2007). Por esta razão, decidimos realizar uma comparação entre as respostas transcricionais globais de células submetidas à hipóxia e carência de ferro (II), e assim tentar encontrar alguma correlação entre estes dois estresses.

No experimento de carência de ferro (II) (seção 4.9) nós comparamos as populações de transcritos dos 3773 genes presentes nos microarranjos, de células cultivadas em 
normóxia $\left(70 \%\right.$ sat. $\left.\mathrm{O}_{2}\right)$, coletadas logo antes com células coletadas 1 hora após a adição de $150 \mu \mathrm{M}$ do quelante de ferro 2,2'-dipyridyl (DPY). Dentre os ESTs analisados, 2435 $(64.5 \%)$ se mostraram expressos nos microarranjos e $219(5.8 \%)$ foram diferencialmente expressos (Tabela S 2). A Figura 23, a seguir, ilustra a distribuição destes 219 genes classificados manualmente em categorias funcionais.

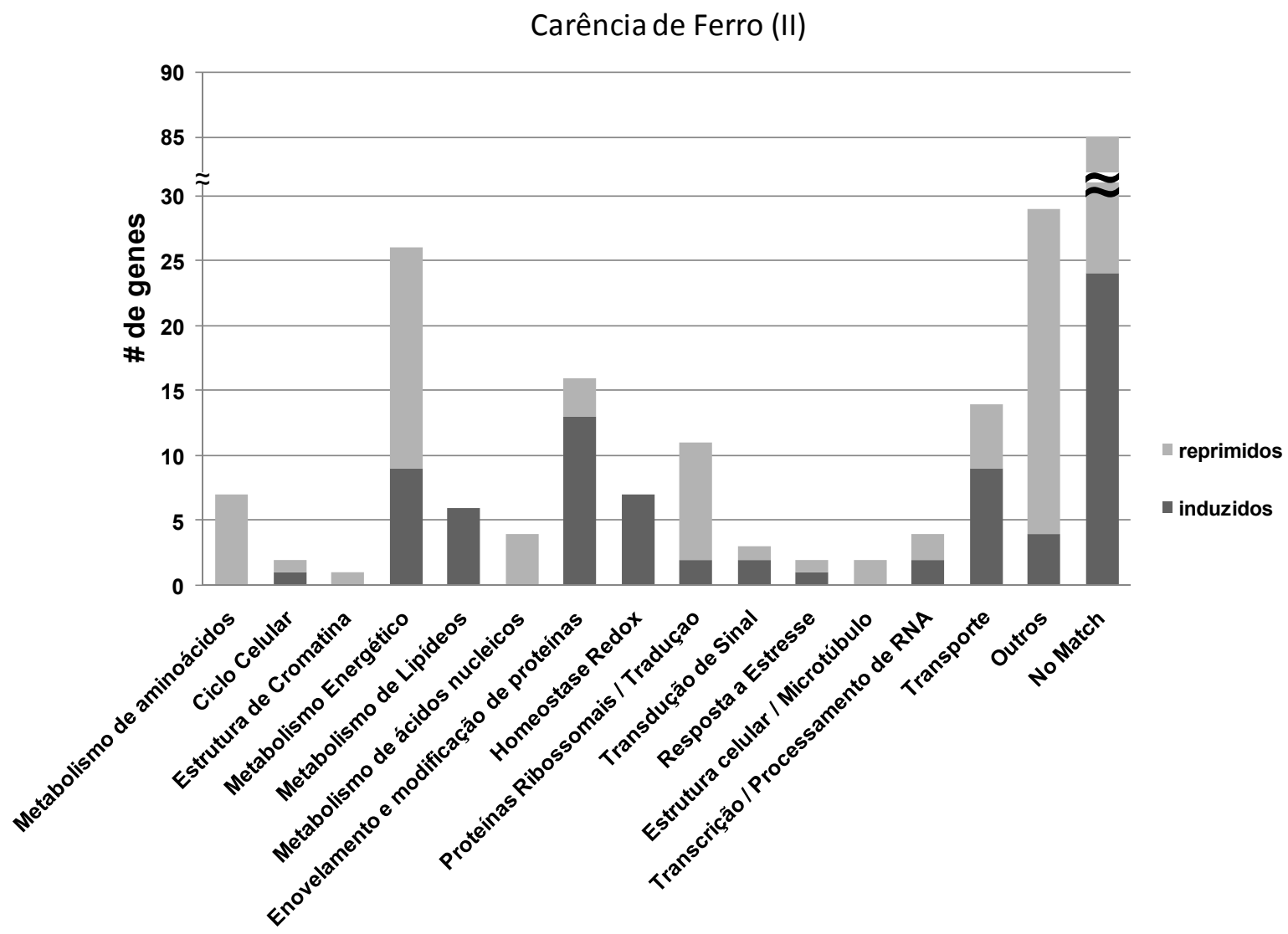

Figura 23: Genes induzidos ou reprimidos durante carência de ferro (II), distribuídos em categorias funcionais.

\subsubsection{Comparação com Hipóxia}

Numa análise comparativa observa-se que, dentre os 219 genes diferencialmente, $112(51.1 \%)$ também foram diferencialmente expressos em hipóxia gradual e/ou direta e, 
surpreendentemente, $79 \%$ deles (88 genes) foram condizentes com os perfis de indução ou repressão observados em hipóxia.

A Tabela 5, a seguir, mostra os genes afetados por carência de ferro (II), que apresentam alguma similaridade com sequências depositadas no GenBank e/ou SwissProt, e sua comparação com os genes afetados por hipóxia gradual e/ou direta. A lista completa, contendo os No Matches e proteínas hipotéticas sem função conhecida, pode ser consultada no Material Suplementar (Tabela S 2). 
Tabela 5: Lista de genes afetados por carência de Ferro (II) obtidos pela técnica de microarranjo de cDNA e a comparação com os microarranjos de hipóxia gradual e/ou direta. Os valores representam a razão de expressão (teste/controle). As setas indicam os perfis de indução (para cima) ou repressão (para baixo).

\begin{tabular}{|c|c|c|c|c|c|c|c|c|c|c|c|c|c|c|c|c|}
\hline \multirow[b]{2}{*}{ Clone ID } & \multirow[b]{2}{*}{ SwissProt } & \multirow[b]{2}{*}{ Annotação } & \multirow[b]{2}{*}{ 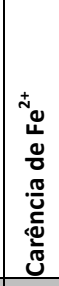 } & \multirow[b]{2}{*}{ 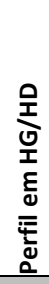 } & \multicolumn{4}{|c|}{ Hipóxia Direta } & \multicolumn{8}{|c|}{ Hipóxia Gradual } \\
\hline & & & & & $\begin{array}{l}f_{1} \\
y^{\prime}\end{array}$ & $\overbrace{-1}^{\frac{1}{\operatorname{n}^{\prime}}}$ & 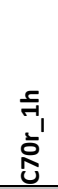 & 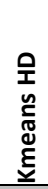 & $\stackrel{0}{0}$ & ஸ્⿹ & $\stackrel{\text { n? }}{\text { ¿n }}$ & น & - & 8 & $\stackrel{0}{0}$ & 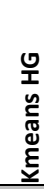 \\
\hline \multicolumn{17}{|c|}{ Metabolismo de Aminoácidos } \\
\hline BeG90N11B07 & & acetolactate synthase Ilv2 [Filobasidiella neoform & 0.3 & & & & & & & & & & & & & \\
\hline BeG30N08D01 & Q9Y3D8 & Adenylate kinase isoenzyme 6 & 0.5 & $\downarrow$ & 0.9 & 0.6 & 0.9 & 4 & 1.0 & 1.0 & 1.0 & 0.9 & 0.6 & 0.6 & 1.1 & 2 \\
\hline BeG60N02D07 & & glycine cleavage system H protein (16.0 kD) & 0.5 & & & & & & 1.0 & 1.0 & 0.8 & 1.0 & 1.0 & 1.0 & 0.6 & 5 \\
\hline BeE60N17D10 & & asparagiNyl tRNA Synthetase NRS-1 (61.2 kD) (nrs-1 & 0.6 & & & & & & & & & & & & & \\
\hline $\mathrm{BeE} 60 \mathrm{H} 21 \mathrm{G} 01$ & & homogentisate 1,2-dioxygenase & 0.6 & & & & & & 1.0 & 1.4 & 1.2 & 1.3 & 0.9 & 1.0 & 0.9 & 4 \\
\hline BeE60H28B12 & Q96VZ6 & Acetolactate synthase Ilv2 & 0.6 & $\downarrow$ & 0.4 & 0.5 & 2.9 & 1 & 1.0 & 1.2 & 1.5 & 1.3 & 0.3 & 0.3 & 1.5 & 1 \\
\hline BeE30N02B01 & 004974 & 2-isopropylmalate synthase B & 0.6 & & & & & & & & & & & & & \\
\hline \multicolumn{17}{|c|}{ Ciclo Celular } \\
\hline BeE120N28B12 & Q9C1M3 & Septin & 0.6 & & & & & & & & & & & & & \\
\hline $\mathrm{BeE} 60 \mathrm{H} 26 \mathrm{CO} 8$ & Q9P3A7 & Cell division cycle protein 48 homolog & 1.7 & & & & & & 1.0 & 0.9 & 0.9 & 1.1 & 0.9 & 1.0 & 0.7 & 5 \\
\hline \multicolumn{17}{|c|}{ Estrutura de Cromatina } \\
\hline BeG30N17G05 & Q1469 & programmed cell death 11 & 0.6 & $\downarrow$ & 0.9 & 0.7 & 0.9 & 4 & & & & & & & & \\
\hline \multicolumn{17}{|c|}{ Metabolismo Energético } \\
\hline BeE90D08B03 & & $\begin{array}{l}\text { glycogen storage control protein, putative } \\
\text { [Cryptococcus }\end{array}$ & 0.3 & & & & & & & & & & & & & \\
\hline BeE120N27B02 & P56205 & Cytochrome c & 0.3 & $\downarrow$ & 0.6 & 0.7 & 1.0 & 1 & 1.0 & 0.9 & 0.9 & 0.9 & 0.5 & 0.3 & 1.4 & 1 \\
\hline BeG120N23E11 & Q99L23 & NADH dehydrogenase (Fragment) & 0.3 & & & & & & & & & & & & & \\
\hline BeG120N07H08 & 074699 & Aconitase & 0.4 & $\downarrow$ & & & & & 1.0 & 0.9 & 0.8 & 0.9 & 1.0 & 0.8 & 1.4 & 2 \\
\hline BeE120N27B03 & Q03015 & $\mathrm{NADH}$-ubiquinone oxidoreductase $12 \mathrm{kDa}$ subunit & 0.5 & $\downarrow$ & & & & & 1.1 & 0.8 & 0.9 & 0.9 & 0.8 & 0.7 & 1.0 & 2 \\
\hline BeZSPN09F10 & Q8J267 & Aconitase (Fragment) & 0.5 & & & & & & & & & & & & & \\
\hline BeE120N08B02 & & aconitase 2, mitochondrial [Danio rerio] & 0.5 & & & & & & & & & & & & & \\
\hline BeE120N20G02 & 097725 & NADH-ubiquinone oxidoreductase subunit B17. & 0.6 & & & & & & & & & & & & & \\
\hline $\begin{array}{l}\text { BeG30N12E07 } \\
\text { BeE120N37A09 }\end{array}$ & $\begin{array}{l}\text { Q9P8D2 } \\
\text { Q7SGS6 }\end{array}$ & $\begin{array}{l}\text { Cytochrome c oxidase subunit V } \\
\text { succinate dehydrogenase flavoprotein subunit } \\
\text { precursor }\end{array}$ & $\begin{array}{l}0.6 \\
0.6\end{array}$ & $\uparrow$ & 1.4 & 1.2 & 0.9 & 5 & & & & & & & & \\
\hline BeG90N12C05 & & glutaryl-Coenzyme A dehydrogenase isoform a & 0.6 & $\downarrow$ & & & & & 1.0 & 1.0 & 0.9 & 0.7 & 0.6 & 0.4 & 0.9 & 2 \\
\hline $\mathrm{BeG} 30 \mathrm{~N} 06 \mathrm{H} 08$ & & Isocitrate Iyase (Isocitrase) (Isocitratase) (ICL) & 0.6 & & & & & & & & & & & & & \\
\hline BeG90N18D03 & & Similar to cytochrome c-1 [Xenopus laevis] & 0.7 & & & & & & & & & & & & & \\
\hline BeG120N10C03 & & NADH-ubiquinone oxidoreductase 30.4 kDa subunit & 0.7 & & & & & & & & & & & & & \\
\hline BeE120N01B06 & P17568 & NADH-ubiquinone oxidoreductase B18 subunit & 0.7 & & & & & & & & & & & & & \\
\hline BeE120N01B08 & & $\mathrm{NADH}$-ubiquinone oxidoreductase $51 \mathrm{kDa}$ subunit & 0.7 & & & & & & & & & & & & & \\
\hline BeG60N09E05 & P52504 & NADH-ubiquinone oxidoreductase 13 kDa-A sub & 0.7 & & & & & & & & & & & & & \\
\hline BeE60H08E04 & Q9A212 & Quinone oxidoreductase & 1.6 & $\uparrow$ & 1.2 & 1.5 & 1.0 & 3 & & & & & & & & \\
\hline BeE60N10B03 & & vacuolar ATP synthase subunit c" & 1.6 & $\uparrow$ & 2.1 & 1.3 & 0.9 & 5 & 0.9 & 1.2 & 1.1 & 1.4 & 2.3 & 2.2 & 0.8 & 6 \\
\hline BeE30N03G09 & Q7PRL2 & V-type ATPase proteolipid subunit & 1.6 & & & & & & & & & & & & & \\
\hline BeE120N28B05 & P48826 & Glucose-6-phosphate 1-dehydrogenase & 1.6 & & & & & & & & & & & & & \\
\hline BeE60N05D05 & Q8EBH2 & Transaldolase & 1.8 & $\uparrow$ & 1.5 & 1.5 & 1.0 & 3 & 1.1 & 1.0 & 1.0 & 1.2 & 1.6 & 3.1 & 0.8 & 6 \\
\hline BeE30N04H06 & Q9Z2K9 & Isocitrate dehydrogenase [NADP] cytoplasmic & 1.8 & $\downarrow$ & & & & & 1.1 & 1.3 & 1.2 & 1.1 & 0.6 & 0.8 & 1.0 & 2 \\
\hline BeE60N18F02 & P48826 & Glucose-6-phosphate 1-dehydrogenase & 1.8 & & & & & & & & & & & & & \\
\hline BeE30N21H07 & P06738 & Glycogen phosphorylase & 2.0 & $\uparrow$ & 1.3 & 2.0 & 1.0 & 3 & 1.1 & 1.1 & 0.9 & 1.2 & 1.4 & 1.7 & 0.7 & 6 \\
\hline BeG90N11A02 & Q90WD9 & Glyceraldehyde 3-phosphate dehydrogenase & 2.2 & $\uparrow$ & 1.9 & 2.4 & 1.2 & 3 & 1.0 & 1.4 & 1.3 & 2.0 & 2.3 & 2.6 & 0.9 & 7 \\
\hline \multicolumn{17}{|c|}{ Metabolismo de Lipídeos } \\
\hline BeE90D17G07 & Q9P4D7 & Long chain polyunsaturated fatty acid elongation & 1.4 & & 0.6 & 1.0 & 0.8 & 1 & 1.0 & 1.0 & 1.1 & 1.4 & 1.2 & 1.3 & 0.6 & 6 \\
\hline
\end{tabular}




\begin{tabular}{|c|c|c|c|c|c|c|c|c|c|c|c|c|c|c|c|c|}
\hline & & enzyme & & & & & & & & & & & & & & \\
\hline BeE60H26A05 & Q872A4 & Related to phosphatidylserine decarboxylase & 1.7 & $\uparrow$ & 5.0 & 2.6 & 1.0 & 6 & 0.9 & 1.8 & 2.5 & 6.1 & 15.8 & 12.6 & 2.7 & 7 \\
\hline BeG90N07B07 & Q7Q192 & leukotriene A4 hydrolase & 1.7 & $\uparrow$ & 1.6 & 1.1 & 0.7 & 5 & & & & & & & & \\
\hline BeE60N03G10 & Q7SBV0 & cyclopropane-fatty-acyl-phospholipid synthase & 1.9 & $\uparrow$ & & & & & 1.1 & 1.8 & 1.5 & 3.8 & 8.9 & 5.7 & 2.0 & 7 \\
\hline BeZSPN11E04 & & deoxyhypusine hydroxylase & 2.5 & & & & & & & & & & & & & \\
\hline BeZSPN15E12 & & deoxyhypusine hydroxylase/monooxygenase & 3.4 & & & & & & & & & & & & & \\
\hline & & Metabolismo de Ácidos Nucleicos & & & & & & & & & & & & & & \\
\hline BeE90D15C05 & 094413 & Ribose-phosphate pyrophosphokinase & 0.5 & $\uparrow$ & 1.9 & 1.7 & 1.3 & 3 & 1.1 & 0.9 & 0.9 & 0.9 & 1.4 & 1.7 & 0.9 & 6 \\
\hline BeG30N12D07 & 093937 & PyrABCN & 0.5 & $\downarrow$ & 0.7 & 1.2 & 2.0 & 1 & 1.0 & 0.7 & 0.4 & 0.7 & 0.6 & 0.8 & 0.9 & 2 \\
\hline BeG30N04E02 & P50094 & Probable inosine-5'-monophosphate dehydroge & 0.6 & & & & & & & & & & & & & \\
\hline BeZSPN03F10 & & probable inosine-5\'-monophosphate dehydrogenase & 0.6 & $\uparrow$ & 1.1 & 1.5 & 1.4 & 3 & & & & & & & & \\
\hline & & Enovelamento e Modificação de Proteínas & & & & & & & & & & & & & & \\
\hline BeE120N06B11 & Q8CEE6 & PAS domain containing serine/threonine kinase & 0.3 & & & & & & & & & & & & & \\
\hline BeG30N13C06 & & Ribosomal RNA processing protein 28 & 0.5 & $\downarrow$ & & & & & 0.9 & 1.1 & & 0.9 & & 0.6 & 1.0 & 2 \\
\hline BeE30N18D09 & Q8UGX7 & Peptide methionine sulfoxide reductase msrB & 0.6 & & & & & & & & & & & & & \\
\hline BeE30N03D10 & P25007 & Peptidyl-prolyl cis-trans isomerase & 1.4 & & & & & & & & & & & & & \\
\hline BeE30N21E09 & Q7ZWL1 & Similar to prolyl endopeptidase (Fragment) & 1.4 & & & & & & & & & & & & & \\
\hline BeE60H28G06 & 073817 & Proteasome subunit beta type 3 & 1.5 & & & & & & & & & & & & & \\
\hline $\mathrm{BeE} 60 \mathrm{H} 23 \mathrm{C} 11$ & Q9W227 & similar to peptidylprolyl isomerase B isoform 1 & 1.5 & & & & & & & & & & & & & \\
\hline BeE60N10D10 & & proteasome subunit alpha type- 4 & 1.5 & & & & & & & & & & & & & \\
\hline BeG120N08G03 & Q13200 & $26 \mathrm{~S}$ proteasome non-ATPase regulatory subuni & 1.5 & & & & & & & & & & & & & \\
\hline BeE60N15G05 & & DnaJ-like protein MsJ1 - alfalfa & 1.6 & $\uparrow$ & 1.6 & 1.2 & 1.0 & 5 & 1.1 & 1.1 & 1.3 & 1.4 & 2.4 & 2.7 & 0.8 & 7 \\
\hline BeE60N13G06 & Q96U28 & Probable $26 s$ proteasome $\mathrm{p} 44.5$ protein & 1.7 & & & & & & & & & & & & & \\
\hline BeG30N09H07 & P52493 & Ubiquitin-conjugating enzyme E2-17 kDa & 1.8 & & & & & & & & & & & & & \\
\hline BeE60H17C06 & P52495 & Ubiquitin-activating enzyme E1 1 (Fragment) & 1.8 & $\uparrow$ & & & & & 1.0 & 1.1 & 1.1 & 1.4 & 1.1 & 1.1 & 0.7 & 6 \\
\hline BeE90D05G05 & Q7Z8F2 & Putative serine/threonine phosphatase $2 \mathrm{C}$ ptc2 & 1.8 & $\uparrow$ & 2.3 & 1.9 & 0.9 & 5 & 1.0 & 1.3 & 1.5 & 2.2 & 4.9 & 4.8 & 0.9 & 7 \\
\hline BeZSPN13B02 & Q9HF04 & Vacuolar serine protease & 1.9 & & & & & & & & & & & & & \\
\hline BeG90N22C02 & Q9PTW9 & Proteasome subunit alpha type 7 & 1.9 & & & & & & & & & & & & & \\
\hline BeE60N14C07 & 014413 & Proteinase $\mathrm{A}$ & 2.2 & & & & & & & & & & & & & \\
\hline & & Homeostase Redox & & & & & & & & & & & & & & \\
\hline BeE60N14F11 & Q9BGI3 & Peroxiredoxin 2 & 1.3 & $\uparrow$ & & & & & 0.7 & 1.1 & 1.2 & 1.3 & 1.3 & 1.3 & 1.1 & 6 \\
\hline BeE90D16C06 & P91252 & Probable glutathione S-transferase 6 & 1.4 & & & & & & & & & & & & & \\
\hline BeE60C04G01 & 014463 & Thioredoxin & 1.5 & & & & & & & & & & & & & \\
\hline BeE60C31E12 & Q94GY8 & Putative glutathione S-transferase & 2.0 & & & & & & & & & & & & & \\
\hline BeE120N37A02 & Q94GY8 & Putative glutathione S-transferase & 2.1 & & & & & & & & & & & & & \\
\hline $\mathrm{BeE} 60 \mathrm{H} 11 \mathrm{CO} 4$ & Q7YXM3 & peroxiredoxins [Phanerochaete chrysosporium] & 3.2 & & & & & & & & & & & & & \\
\hline BeE60C19G01 & & Thioredoxin peroxidase & 3.4 & $\downarrow$ & 0.6 & 1.1 & 1.0 & 1 & & & & & & & & \\
\hline & & Proteínas Ribossômicas / Tradução & & & & & & & & & & & & & & \\
\hline BeG60N15D01 & 07469 & SNU13 snRNP subunit homolog & 0.3 & $\downarrow$ & 0.6 & 0.5 & 0.9 & 1 & 1.0 & 0.9 & 0.9 & 0.8 & 0.4 & 0.2 & 1.2 & 1 \\
\hline BeG90N10A10 & P32495 & High mobility group & 0.4 & $\downarrow$ & & 0.5 & 0.9 & & 1.0 & 1.0 & 0.9 & 0.9 & 0.5 & 0.4 & 1.2 & 2 \\
\hline BeG120N20E02 & Q9NPE3 & H/ACA ribonucleoprotein complex subunit 3 & 0.4 & $\downarrow$ & 0.4 & 0.4 & 0.9 & 2 & 0.9 & 0.9 & 1.1 & 0.9 & 0.3 & 0.3 & 1.3 & 2 \\
\hline BeG120N02A10 & Q09916 & Putative ATP dependent RNA helicase C1F7.02 & 0.4 & $\downarrow$ & 0.6 & 0.6 & 0.9 & 1 & 1.0 & 1.0 & 0.9 & 0.9 & 0.4 & & 1.1 & 1 \\
\hline BeG120N22A08 & P38805 & Ribosome biogenesis protein RPF1 & 0.5 & & & & & & & & & & & & & \\
\hline BeG90N04A04 & & Probable eukaryotic translation initiation factor & 0.5 & $\downarrow$ & 0.6 & 0.7 & 1.1 & 1 & & & & & & & & \\
\hline BeZSPN17H02 & & similar to Fibrillarin CG9888PA & 0.6 & $\downarrow$ & & & & & 1.0 & 1.0 & 0.9 & 0.9 & 0.5 & 0.4 & 1.1 & 2 \\
\hline BeG90N19G08 & Q8S1Z1 & U3 small nucleolar RNA-associated & 0.6 & & & & & & & & & & & & & \\
\hline BeG120N04E02 & & H. sapiens eukaryotic translation initiation factor $1 \mathrm{~A}$ & 0.7 & $\downarrow$ & & & & & 0.9 & 0.9 & 0.9 & 0.8 & 0.7 & 0.6 & 1.0 & 2 \\
\hline BeE90N16A07 & Q7MXM0 & Aspartyl-tRNA synthetase & 1.8 & & & & & & & & & & & & & \\
\hline BeE90D07H12 & P25444 & $40 S$ ribosomal protein S2 & 1.8 & & & & & & & & & & & & & \\
\hline & & Transdução de Sinal & & & & & & & & & & & & & & \\
\hline BeE90D03C08 & Q8BWJ3 & $\begin{array}{l}\text { Phosphorylase B kinase alpha regulatory chain, liver } \\
\text { isoform }\end{array}$ & 0.7 & & & & & & & & & & & & & \\
\hline BeZSPN16D09 & Q12741 & cAMP-dependent protein kinase catalytic sub & 1.4 & $\uparrow$ & 1.2 & 1.4 & 1.3 & 3 & & & & & & & & \\
\hline BeG90N08A02 & Q9W7I1 & activated protein kinase $\mathrm{C}$ receptor & 1.5 & $\uparrow$ & 0.9 & 1.4 & 1.1 & 3 & & & & & & & & \\
\hline & & Resposta a Estresse & & & & & & & & & & & & & & \\
\hline BeG60N07C03 & Q9S9N1 & Hsp70-3 (Blastocladiella emersonii) & 0.7 & $\downarrow$ & & & & & 1.1 & 1.0 & 0.8 & 0.8 & 0.6 & 0.7 & 1.0 & 2 \\
\hline BeE60H30A07 & Q818Z4 & Heat shock protein 90 (Fragment) & 1.6 & & & & & & & & & & & & & \\
\hline & & Estrutura Celular / Microtúbulos & & & & & & & & & & & & & & \\
\hline BeE90N19F03 & Q8WXX0 & Ciliary dynein heavy chain 7 & 0.5 & & & & & & & & & & & & & \\
\hline BeE60N10H11 & & kinesin heavy chain & 0.6 & & & & & & & & & & & & & \\
\hline & & Transcrição / Processamento de RNA & & & & & & & & & & & & & & \\
\hline BeG90N10B01 & & DNA-directed RNA polymerase I subunit D protein & 0.5 & $\downarrow$ & 0.6 & 0.6 & 1.0 & 1 & 0.9 & 1.0 & 0.9 & 0.9 & 0.5 & 0.5 & 1.3 & 2 \\
\hline
\end{tabular}




\begin{tabular}{|c|c|c|c|c|c|c|c|c|c|c|c|c|c|c|c|c|}
\hline BeE30N22H05 & 081098 & RNA polymerase I, II and III $24.3 \mathrm{kDa}$ subun & 0.6 & $\downarrow$ & 0.2 & 0.7 & 1.0 & 2 & & & & & & & & \\
\hline BeE90D08E03 & P34253 & RNA polymerase II elongator-associated protein & 1.9 & $\uparrow$ & 2.1 & 1.7 & 0.9 & 5 & 1.0 & 1.2 & 1.5 & 2.0 & 3.9 & 4.5 & 0.9 & 7 \\
\hline \multicolumn{17}{|c|}{ Transporte } \\
\hline BeG60N20F09 & Q87216 & Probable iron inhibited $A B C$ transporter $2 \mathrm{G}$ & 0.4 & $\downarrow$ & 0.7 & 0.7 & 1.0 & 1 & 1.0 & 1.0 & 1.1 & 1.0 & 0.7 & 0.7 & 1.4 & 2 \\
\hline BeZSPN05F06 & & hypothetical protein [Neurospora crassa] & 0.5 & $\downarrow$ & & & & & 1.0 & 1.0 & 1.0 & 0.9 & 0.7 & 0.8 & 1.5 & 2 \\
\hline BeE60C03A02 & & Cation/multidrug efflux pump [Pseudomonas & 0.6 & & & & & & & & & & & & & \\
\hline BeE60N18C10 & & $\begin{array}{l}\text { Acyl carrier protein, mitochondrial precursor (ACP } \\
\text { putative phosphate/phosphoenolpyruvate }\end{array}$ & 0.6 & & & & & & & & & & & & & \\
\hline BeE60N18A11 & & translocator & 0.7 & $\downarrow$ & & & & & 1.0 & 1.0 & 0.9 & 1.0 & 0.8 & 0.6 & 0.8 & 2 \\
\hline BeNSVP07B10 & & proton glutamate symport protein & 1.4 & $\uparrow$ & 0.9 & 1.6 & 1.0 & 3 & 0.8 & 0.8 & 1.0 & 1.2 & 1.4 & 1.8 & 1.0 & 6 \\
\hline BeG60N01F09 & & methionine permease, putative [Neosartorya fischeri & 1.8 & $\uparrow$ & 1.6 & 2.1 & 0.9 & 3 & & & & & & & & \\
\hline BeE60N12D06 & Q9JL62 & Glycolipid transfer protein & 2.0 & $\uparrow$ & 2.3 & 1.7 & 1.1 & 5 & 1.0 & 1.3 & 1.3 & 1.9 & 2.8 & 2.8 & 1.0 & 7 \\
\hline BeG30N13H08 & Q9JL97 & GPI-anchored ceruloplasmin & 2.5 & & & & & & 1.1 & 1.0 & 1.1 & 0.8 & 0.6 & & 0.7 & 5 \\
\hline BeZSPN15C05 & & high-affinity iron permease [Rhizopus oryzae] & 2.7 & $\downarrow$ & & & & & & 0.9 & & 0.8 & & 0.6 & 0.5 & 2 \\
\hline BeG90N02G07 & Q8JZT2 & S-adenosylmethionine mitochondrial carrier protein & 2.7 & & & & & & & & & & & & & \\
\hline BeG30N20G10 & & ABC transporter-like protein [Arabidopsis thaliana & 3.3 & & & & & & & & & & & & & \\
\hline BeG120N25D02 & Q92341 & siderophore iron transporter mirC & 4.9 & & & & & & & & & & & & & \\
\hline BeG30N19E11 & & zinc/iron permease & 8.9 & & & & & & 1.0 & 1.6 & 1.1 & 0.5 & 0.6 & 1.0 & 0.6 & 5 \\
\hline \multicolumn{17}{|c|}{ Outros } \\
\hline BeE90N06H03 & Q81CV0 & Hydrolase & 0.2 & $\downarrow$ & & 0.1 & & & & 0.4 & 0.7 & 0.2 & & 0.3 & 1.2 & 8 \\
\hline BeE60C18D04 & Q8FW89 & Quinone oxidoreductase & 0.2 & & & & & & & & & & & & & \\
\hline BeNSVP04C06 & P19727 & Minor capsid protein 10B & 0.3 & & & & & & & & & & & & & \\
\hline BeG30N20D08 & Q9UUG1 & Brix domain containing protein 1 homolog & 0.3 & $\downarrow$ & 0.5 & 0.7 & 1.0 & 1 & 0.9 & 1.2 & 0.9 & 0.9 & & 0.4 & 1.2 & 1 \\
\hline BeG60N08E04 & 042468 & PP2A inhibitor & 0.4 & $\downarrow$ & 0.5 & 0.6 & 1.0 & 1 & 1.0 & 1.1 & 0.7 & 0.8 & 0.3 & 0.3 & 1.2 & 1 \\
\hline BeE60C21A11 & Q88FF9 & Outer membrane siderophore receptor & 0.4 & & & & & & & & & & & & & \\
\hline BeG60N12C05 & Q9BQ67 & Glutamate-rich WD-repeat protein 1 & 0.5 & & & & & & & & & & & & & \\
\hline BeG90N07D08 & Q8EIN1 & Alkaline phosphatase, putative & 0.5 & & & & & & & & & & & & & \\
\hline BeE60C15B06 & & Fe2+-dicitrate sensor & 0.6 & $\downarrow$ & 0.3 & 0.9 & 0.8 & 2 & & & & & & & & \\
\hline BeZSPN14H05 & & histidinol phosphate aminotransferase & 0.6 & $\downarrow$ & 0.7 & 1.0 & 1.4 & 1 & 1.0 & 0.7 & 0.7 & 0.7 & 0.3 & 0.2 & 0.7 & 1 \\
\hline BeE60N16C10 & & fiber protein Fb27 [Gossypium barbadense] & 0.7 & $\downarrow$ & 0.1 & 0.9 & 0.9 & 2 & & & & & & & & \\
\hline $\mathrm{BeG} 30 \mathrm{~N} 10 \mathrm{H} 02$ & & zinc finger, HIT type 6 & 0.7 & & & & & & & & & & & & & \\
\hline BeE60C05B10 & Q882A7 & Oxidoreductase, Gfo/Idh/MocA family & 0.7 & $\downarrow$ & 0.5 & 0.7 & 0.9 & 1 & & & & & & & & \\
\hline BeG30N18H02 & 014236 & gtp-binding protein associated & 0.7 & & & & & & & & & & & & & \\
\hline BeE60C06H06 & Q7WWT9 & Putative NagM-like protein & 0.7 & $\downarrow$ & 0.7 & 0.7 & 0.8 & 4 & & & & & & & & \\
\hline BeG120N02B04 & P32469 & Diphthine synthase & 0.7 & $\downarrow$ & 0.5 & 0.5 & 0.9 & 1 & 1.0 & 1.0 & 0.8 & 0.9 & 0.5 & 0.4 & 1.1 & 1 \\
\hline BeG120N23D09 & & putative protein disulfate isomerase & 1.5 & $\uparrow$ & 1.5 & 1.8 & 1.1 & 3 & 1.0 & 1.2 & 1.2 & 1.5 & 1.9 & 1.6 & 0.8 & 6 \\
\hline
\end{tabular}

Embora nem todos os genes cuja expressão é alterada por hipóxia sejam também afetados por tratamento com DPY, as categorias funcionais observadas apresentaram comportamento semelhante nos dois casos, indicando que carência de $\mathrm{Fe}^{2+}$ e hipóxia compartilham respostas transcricionais semelhantes, tanto no que diz respeito individualmente aos genes, quanto a processos fisiológicos como um todo.

No Metabolismo de Aminoácidos, por exemplo, todos os genes afetados se apresentaram reprimidos pela carência de ferro, seguindo a tendência observada nos experimentos de hipóxia (seção 5.1.7.2). 
No Metabolismo Energético, observamos a repressão de genes relacionados à cadeia respiratória (NADH-ubiquinone oxidoreductase, cytochrome c e Cytochrome c oxidase subunit $V$ ) e ciclo do ácido cítrico (aconitase, succinate dehydrogenase e isocitrate lyase) e indução de genes relacionados ao metabolismo de glicose (Glycogen phosphorylase, Glyceraldehyde 3-phosphate dehydrogenase, Glucose-6-phosphate 1-dehydrogenase e Transaldolase), além de ATPases vacuolares (vacuolar ATP synthase subunit c e V-type ATPase proteolipid subunit). Apesar de nem todos os genes afetados por hipóxia estarem também afetados por carência de ferro, podemos observar que o padrão de resposta do sistema como um todo, com priorização do metabolismo glicolítico, frente ao respiratório, de certa forma foi mantido.

No Metabolismo de Lipídeos, também seguindo a tendência observada em hipóxia, todos os seis genes afetados foram induzidos, dentre os quais, três genes também induzidos por hipóxia. Devido à importância do metabolismo de lipídeos na resposta a hipóxia em outros organismos (seção 5.1.7.7), isso nos dá mais um indício de que o ferro (II) pode ter importância no sistema sensor de oxigênio em B. emersonii.

Quanto à Homeostase Redox, a carência de ferro parece ser mais danosa do que a hipóxia, pois se observa a indução de sete genes que codificam proteínas protetoras contra estresse redox, ao passo que em hipóxia observamos menos genes induzidos e alguns até reprimidos.

No caso da categoria Proteínas Ribossômicas / Tradução, a semelhança com a hipóxia é ainda mais evidente. Podemos observar que grande parte dos genes afetados foram reprimidos, sendo que muitos deles são os mesmos genes reprimidos em hipóxia.

Na categoria Transdução de Sinal observamos induzidos tanto em hipóxia quanto em carência de ferro, o genes que codificam a subunidade catalítica da proteína quinase dependente de cAMP (cAMP-dependent protein kinase catalytic subunit) e o receptor da 
proteína quinase $\mathrm{C}$ (activated protein kinase $C$ receptor), indicando que este tipo de sinalização atua em ambos os estresses.

A categoria Transcrição / Processamento de RNA merece destaque, pois todos os genes afetados também aparecem no estresse de hipóxia e de maneira condizente. Dois genes codificando subunidades da RNA polimerase foram reprimidos e um gene codificando um fator de elongação da RNA polimerase foi induzido.

$\mathrm{Na}$ categoria Transporte, três genes que codificam transportadores de ferro foram altamente induzidos (high-affinity iron permease, siderophore iron transporter mirC e zinc/iron permease), o que é certamente um reflexo da carência de ferro causada pelo tratamento das células com 2,2'-dipyridyl. Além disso, diversos genes relacionados a transporte foram afetados de maneira semelhante ao observado em hipóxia, como por exemplo, foram induzidos os genes de transportadores de fosfoenolpiruvato (phosphate/phosphoenolpyruvate translocator), de glutamato (proton glutamate symport protein) e de metionina (methionine permease).

Em resumo, podemos concluir que as semelhanças observadas entre os perfis transcricionais nos experimentos hipóxia e de carência de $\mathrm{Fe}^{2+}$, sugerem que estes estresses estão de alguma forma conectados, fornecendo bons indícios de que o íon $\mathrm{Fe}^{2+}$ possa ter papel importante no mecanismo sensor de oxigênio e/ou de resposta a hipóxia em $B$. emersonii.

\subsubsection{Validação dos Microarranjos de cDNA}

Os microarranjos de carência de ferro (II) também foram validados por qRT-PCR. Desta vez utilizamos como normalizador o gene BeE60H06B09 que codifica a histona H2A, H2A, pois este não se apresentou afetado por carência de ferro (II) nos microarranjos. Pode- 
se observar na que as duas metodologias são qualitativamente coincidentes, o que valida os resultados de microarranjo.

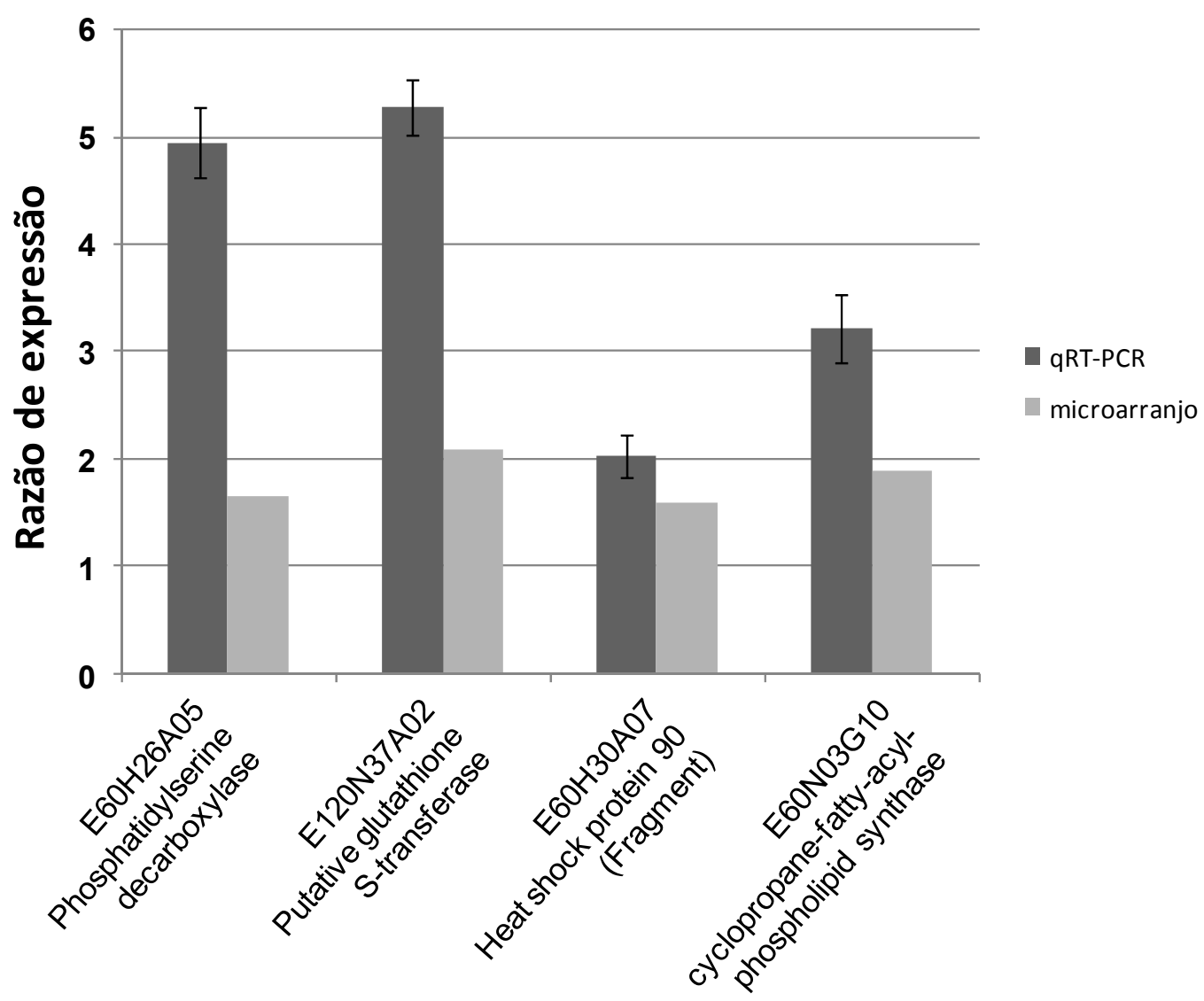

Figura 24: Validação dos experimentos de microarranjos com células em Carência de Ferro por RT-PCR quantitativo. As barras verticais representam os desvios-padrão das análises realizadas em duplicata biológica.

\subsection{Genes regulados por hipóxia, carência de $\mathrm{Fe}^{2+}$, cádmio e choque térmico}

Como já foi mencionado anteriormente, o projeto de sequenciamento em larga escala de clones de cDNAs de B. emersonii, desenvolvido por nosso laboratório, proporcionou estudos sobre expressão gênica diferencial deste fungo sob diversos tipos de diferencial deste fungo sob condições de estresse, como exposição a cádmio $\left(\mathrm{Cd}^{2+}\right)$ e a choque térmico (Georg and Gomes, 2007). Nestes estudos também foi mostrado que uma grande quantidade 
de genes "No matches", ou seja, sem qualquer similaridade no banco de dados do GenBank, são regulados por estes estresses.

A fim de procurarmos potenciais funções para estes genes sem função conhecida, realizamos uma análise comparativa entre os genes diferencialmente expressos tanto nos estresses por cádmio e choque térmico, quanto nos estresses por hipóxia e carência de ferro (II), obtidos no presente trabalho (Tabela 6). Podemos observar nesta tabela que cinco genes foram diferencialmente expressos nos quatro tipos de estresse.

Tabela 6: Genes regulados por hipóxia, carência de $\mathrm{Fe}^{2+}$, cádmio e choque térmico. Os resultados de cádmio e choque térmico foram obtidos por nosso grupo de pesquisa (Georg and Gomes, 2007). Os valores representam a razão de expressão (teste/controle). Os dados de cádmio foram obtidos em duas concentrações de metal (100 e $200 \mu \mathrm{M})$ e, assim como em choque térmico, foram adquiridos tanto em células de esporulação (E) quanto de germinação (G).

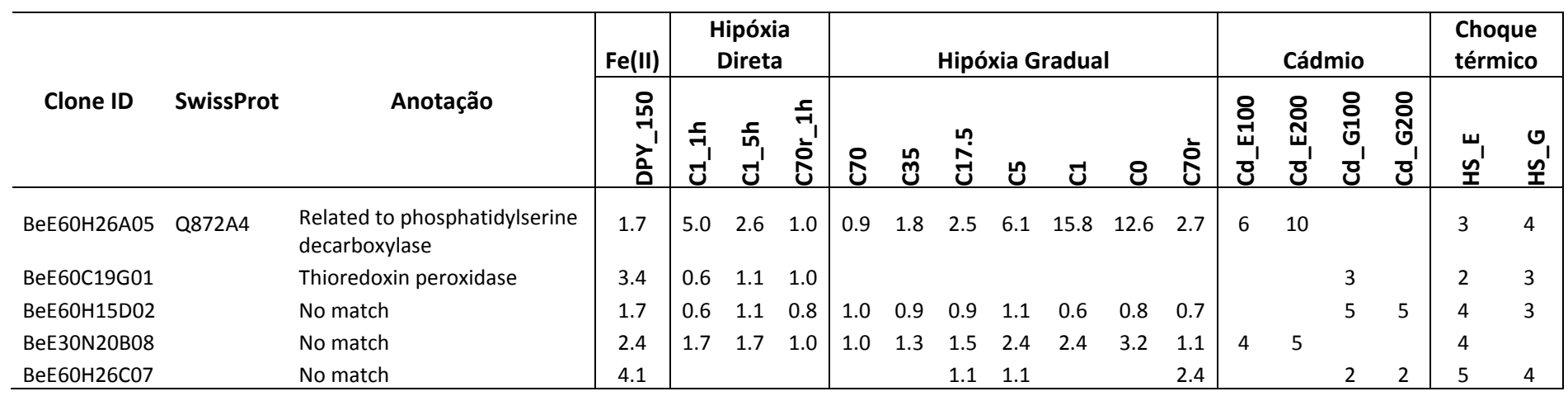

O gene que codifica uma provável fosfatidilserina descarboxilase (phosphatidylserine decarboxylase), enzima formadora de fosfatidiletanolamina e participante da biossíntese de fosfolipídeos, é bastante induzido em todos os estresses. De fato, o aumento da proporção de fosfatidiletanolamina na membrana leva a um aumento de sua fluidez, o que poderia contribuir para a tolerância aos diferentes estresses. A mesma indução foi observada para dois genes “No matches” (BeE30N20B08 e BeE60H26C07), 
indicando que estes genes devem possuir um papel importante na resposta geral a estresses, em B.emersonii. O gene que codifica a enzima tiorredoxina peroxidase (thioredoxin peroxidase) e o "No match" BeE60H15D02 foram induzidos somente em carência de Fe2+, cádmio e choque térmico, porém reprimidos em hipóxia gradual e direta.

\subsection{Hipóxia + Geldanamicina}

Como foi mencionado anteriormente (seção 2.2), em mamíferos, a HSP90 possui um papel protetor de HIF-1 $\alpha$ em relação à sua degradação pelo proteassomo de maneira $\mathrm{O}_{2} / \mathrm{PHD} /$ VHL-independente. Apesar de não se ter encontrado até o momento nenhum homólogo de HIF-1 $\alpha$ em B. emersonii, dois cDNAs codificando HSP90 distintas foram recentemente caracterizados (Pugliese et al., 2008). Na busca de evidências de um mecanismo similar ao HIF-1 neste fungo, comparamos através da técnica de microarranjos, a população de transcritos de células tratadas e não-tratadas com $2 \mu \mathrm{M}$ geldanamicina, um inibidor da HSP90, ambas a células submetidas a uma hora de hipóxia direta (seção 4.10). Assim, tomando como condição controle as células não-tratadas esperava-se que genes regulados por um suposto fator HIF 1- $\alpha$, deveriam estar regulados negativamente, pois a falta de HIF1- $\alpha$ estável mesmo em condições de hipóxia, uma vez que a inibição de HSP90 leva a uma constante degradação deste fator, independentemente de oxigênio.

De fato, encontramos 111 genes regulados negativamente quando as células sob hipóxia foram tratadas com geldanamicina. No entanto, somente 12 destes genes foram encontrados induzidos nos experimentos de hipóxia gradual e/ou direta (Tabela 7). Os outros genes foram provavelmente afetados por alterações transcricionais causadas pela geldanamicina, independentemente de hipóxia. A tabela completa, contendo todos os genes diferencialmente expressos neste experimento, é mostrada no Material Suplementar (Tabela S 3). 
Tabela 7: Genes de hipóxia afetados pelo tratamento com geldanamicina. Valores expressos em número de vezes reprimido. As setas indicam os perfis de expressão dos experimentos de hipóxia gradual e/ou direta.

\begin{tabular}{|c|c|c|c|c|}
\hline Clone ID & SwissProt & Anotação & 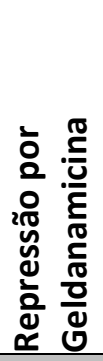 & 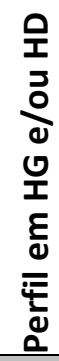 \\
\hline \multicolumn{5}{|c|}{ Metabolismo Energético } \\
\hline BeE60N05D05 & Q8EBH2 & Transaldolase & -1.6 & $\uparrow$ \\
\hline BeG90N18E08 & Q8X97 & Probable ATP-citrate synthase subunit 1 & -1.7 & $\uparrow$ \\
\hline BeE120N03E01 & Q8ZN3 & D-lactate dehydrogenase & -1.4 & $\uparrow$ \\
\hline \multicolumn{5}{|c|}{ Metabolismo de Lipídeos } \\
\hline BeE60H26A05 & Q872A4 & Related to phosphatidylserine decarboxylase & -1.6 & $\uparrow$ \\
\hline BeG60N06G05 & P7978 & Delta-9 fatty acid desaturase & -2.0 & $\uparrow$ \\
\hline BeG90N07B07 & & leukotriene A4 hydrolase & -1.5 & $\uparrow$ \\
\hline \multicolumn{5}{|c|}{ Estrutura Celular / Microtúbulos } \\
\hline BeE60N13F03 & & beta-tubulin [Blastocladiella emersonii] & -1.4 & $\uparrow$ \\
\hline \multicolumn{5}{|c|}{ Transporte } \\
\hline BeG90N07C10 & Q8TGD1 & tricarboxylate carrier, putative & -5.8 & $\uparrow$ \\
\hline \multicolumn{5}{|c|}{ No Match } \\
\hline BeE60N01B04 & & No match & -1.7 & $\uparrow$ \\
\hline BeE90D14D07 & & No match & -1.9 & $\uparrow$ \\
\hline BeE60N18B07 & & No match & -1.4 & $\uparrow$ \\
\hline BeE60H08F12 & & No match & -1.7 & $\uparrow$ \\
\hline
\end{tabular}

É interessante notar que alguns dos genes de hipóxia afetados pelo tratamento com geldanamicina codificam proteínas de destacada importância para o estresse de hipóxia, como já foi mencionado anteriormente (seção 5.1.7). A expressão de quatro destes genes foi confirmada por RT-qPCR e mostrou que realmente a sua indução por hipóxia é diminuída quando as células são tratadas previamente com geldanamicina (Figura 25). Também avaliamos a expressão do gene que codifica uma anidrase carbônica putativa 
(BeG30N15D05), pois em mamíferos, a anidrase carbônica é um dos principais alvos do fator HIF1- $\alpha$. Sua expressão foi marcadamente induzida sob hipóxia, mas não pôde ser obtida nos microarranjos do experimento de geldanamicina devido a artefatos na lâmina.

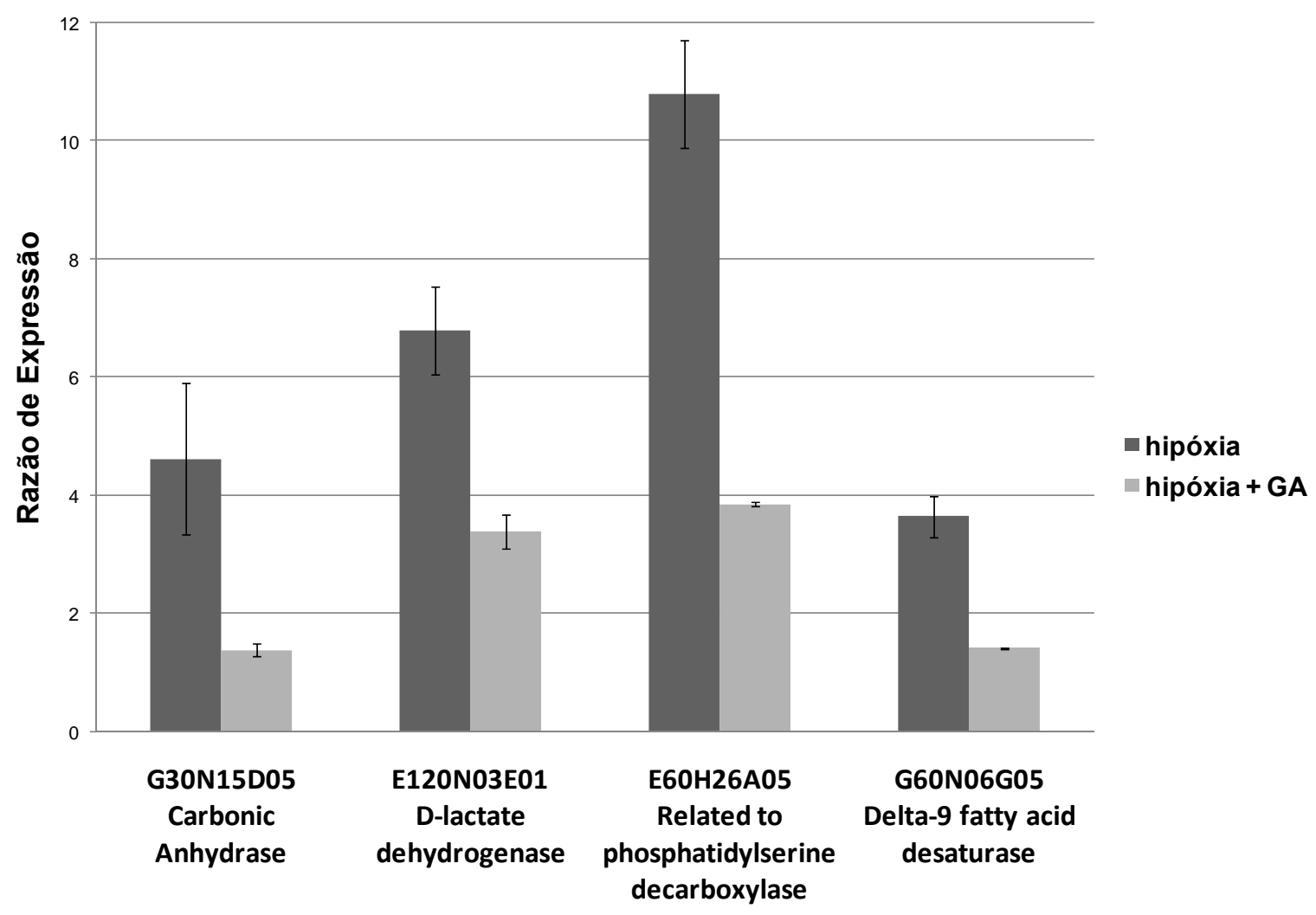

Figura 25: Validação dos microarranjos do experimento Hipóxia + Geldanamicina. Pode-se notar que nas células submetidas à hipóxia + geldanamicina, a indução dos genes foi menor do que sem geldanamicina. As barras verticais representam os desvios-padrão das análises realizadas em duplicata biológica.

Deste modo, não resta dúvidas de que o antibiótico geldanamicina possui algum efeito sobre a expressão de genes de hipóxia em B. emersonii. Entretanto, esses resultados não provam que este fungo possui algum mecanismo semelhante ao HIF1- $\alpha$, mas nos fornece uma pista intrigante e uma forte razão para continuarmos investigando. 


\subsection{Uma proteína de quitridiomiceto similar ao fator inibitório de HIF-1a (FIH)}

Não encontramos em nossa base de dados de cDNAs de B. emersonii (http://blasto.iq.usp.br) um transcrito que possua similaridade com HIF1- $\alpha$. No entanto, mesmo entre os organismos que possuem este fator, ele não é muito conservado, o que torna difícil a identificação de homólogos em outras espécies.

O fungo evolutivamente mais próximo de Blastocladiella emersonii, com genoma seqüenciado, é o quitridiomiceto patógeno de anfíbios Batrachochytrium dendrobatidis. Realizamos uma busca por fatores que participam da via de HIF1- $\alpha$ no genoma deste fungo (disponível em www.broadinstitute.org) e encontramos uma proteína hipotética com um domínio Jmjc (BDEG_02431.1), muito similar à proteína JMJD5 de metazoários (de função desconhecida). As proteínas JMJD5 são da mesma família (“only-Jmjc-domain-contaning protein") do fator inibitório de HIF1- $\alpha$ (FIH) (Klose et al., 2006). FIH é uma dioxigenase dependente de $\alpha$-cetoglutarato, que hidroxila um resíduo de asparagina (Asp ${ }^{803}$ ) de HIF-1 $\alpha$, levando à sua inativação devido ao bloqueio de sua interação com seus coativadores CBP e p300, impedindo assim, a indução de genes de hipóxia (Semenza, 2007; Taylor, 2008).

A principal diferença entre JMJD5 e o fator FIH é uma substituição de um resíduo de treonina por serina (Figura 26) no primeiro sítio de ligação a $\alpha$-cetoglutarato (Klose et al., 2006). Mesmo que ainda não se conheça a função da proteína JMJD5, o fato de existir uma proteína de quitridiomiceto com domínio tão parecido com o de FIH, nos indica que existe a chance de existir, nestes fungos, um mecanismo de homeostase de oxigênio semelhante ao do HIF-1 $\alpha$. 


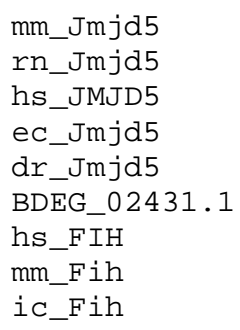

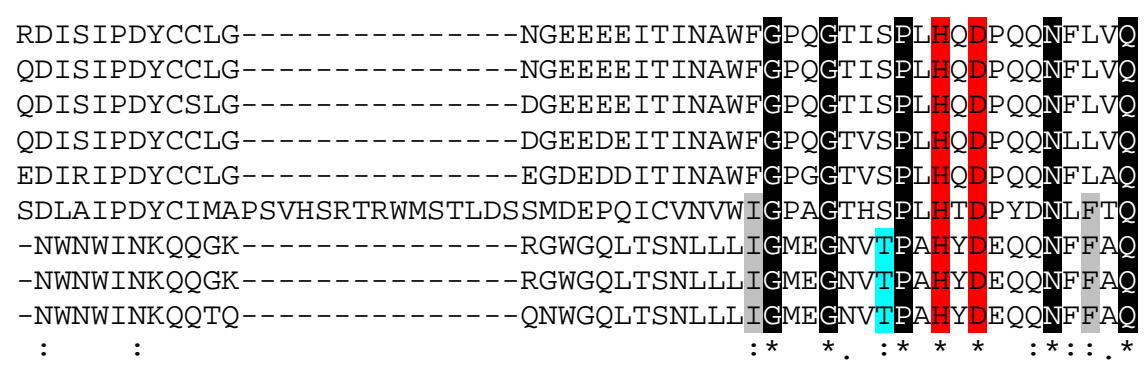
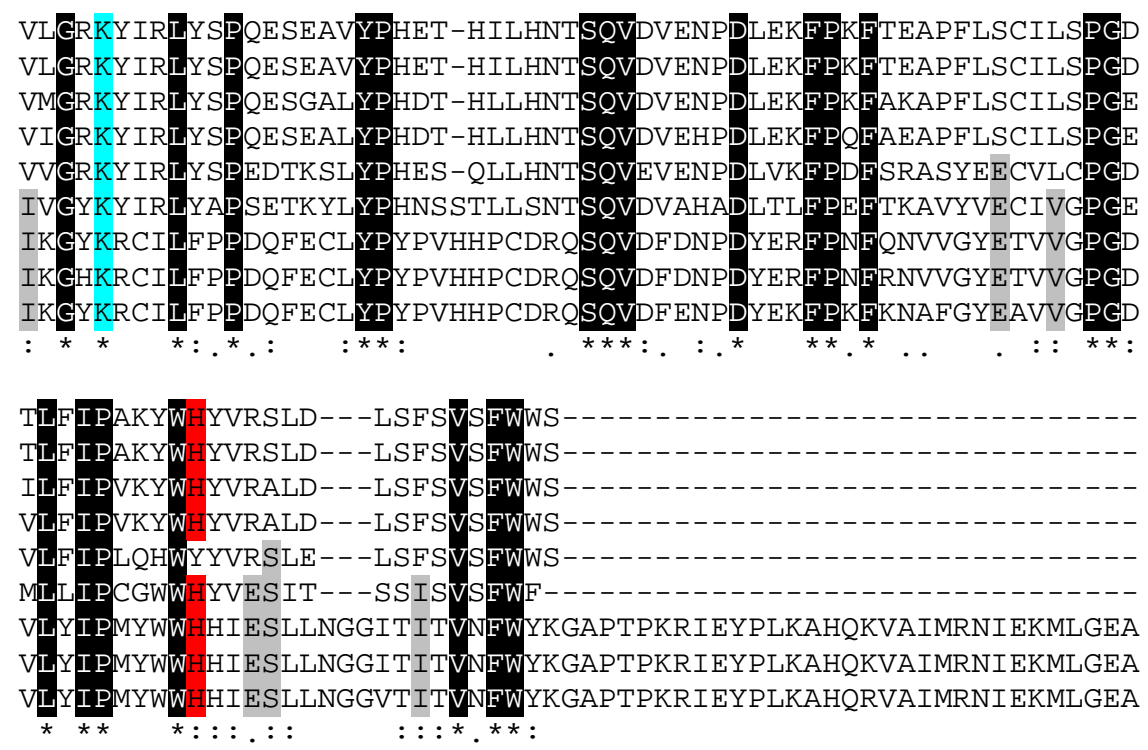

Figura 26: Alinhamento das sequências dos domínios Jmjc da proteína hipotética de $B$. dendrobatidis (BDEG_02431.1) e das proteínas JMJD5 e FIH de metazoários. Sítios de ligação a $\mathrm{Fe}(\mathrm{II})$ (vermelho), sítios de ligação a $\alpha$-cetoglutarato (azul) e resíduos conservados (preto e cinza), estão destacados em cada ortólogo para mostrar as similaridades e diferenças entre as proteínas. $\mathrm{mm}=$ Mus musculus; $\mathrm{rn}=$ Rattus novergicus; hs=Homo sapiens; $\mathrm{dr}=$ Danio rerio; ic $=$ Ictalurus punctatus; $\mathrm{ec}=$ equus caballus.

\subsection{Transformação de B. emersonii mediada por Agrobacterium tumefasciens}

Para estabelecer uma metodologia de transformação de Blastocladiella emersonii mediada por Agrobacterium tumefasciens, foi construído o vetor binário pBINPLUS-Hph (seção 4.15.1), que carrega um T-DNA, o qual contém o gene de resistência a higromicina B, codificando a enzima higromicina B fosfotransferase (hph), sob controle do promotor e terminador trpC de Aspergillus nidulans. 
Como $B$. emersonii é um fungo aquático e requer um meio úmido, não é possível observar sua resistência a higromicina B através da formação de colônias. No entanto, a sensibilidade das células a este antibiótico pode ser observada por microscopia óptica, já que células selvagens sensíveis não são capazes de crescer normalmente e nem esporular na presença do antibiótico (Figura $27 \mathbf{A})$.

Pudemos observar que o protocolo desenvolvido (seção 4.15.2) resultou na transferência do T-DNA presente no vetor pBINPLUS-Hph, evidenciado pelo crescimento normal e esporulação das células transformadas, na presença de higromicina B (Figura 27 B). Quando B. emersonii foi co-cultivada com A. tumefaciens contend o plasmídeo pBINPLUS vazio, não houve crescimento normal e nenhum zoósporo resistente pode ser selecionado.

A

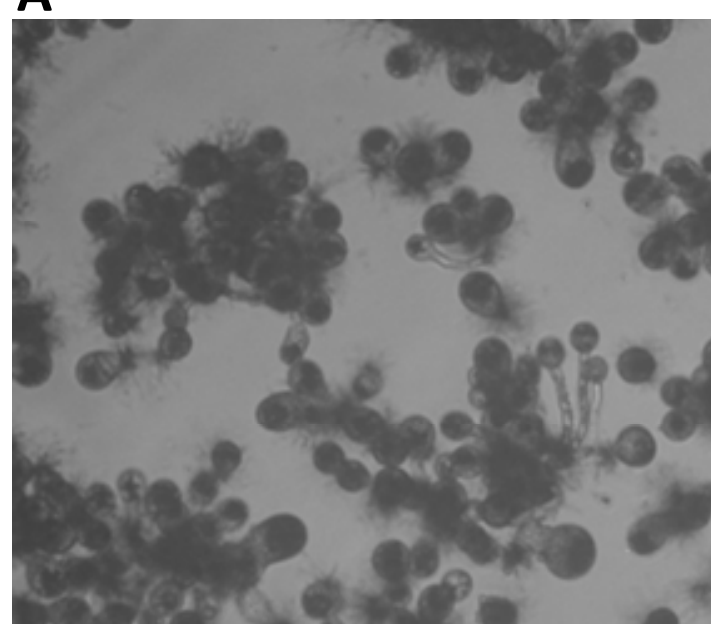

B

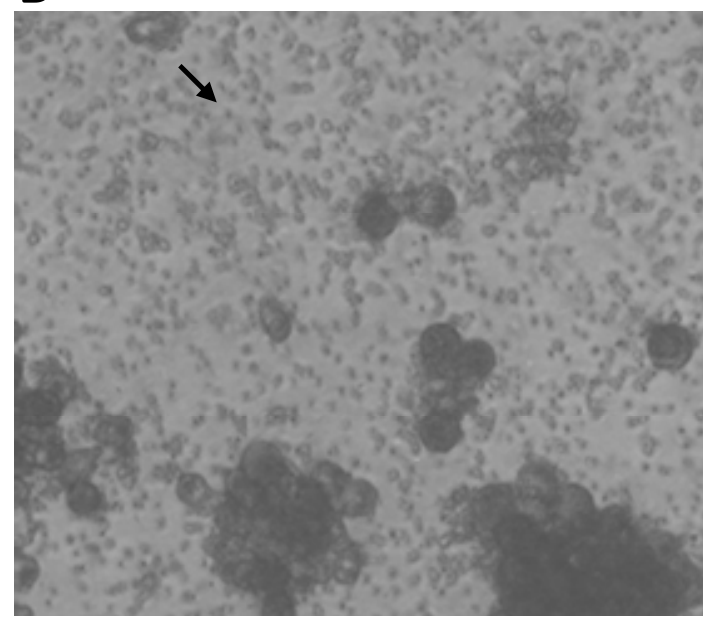

Figura 27: Aparência típica dos transformantes resistentes a higromicina B. (A) Células selvagens não transformadas, mostrando morfologia e crescimento anormais e interrupção completa da esporulação, causados pela higromicina B. (B) Células resistentes a higromicina B, mostrando crescimento normal e esporulação. A seta indica um dos muitos zoósporos liberados. Ambas as culturas foram feitas em meio PYG contendo $250 \mu \mathrm{g} \cdot \mathrm{mL}^{-1}$ de higromicina B. 
Para termos certeza de que o T-DNA de A. tumefaciens foi transferido para o DNA genômico de $B$. emersonii, foi realizada uma extração rápida de DNA (seção 4.15.3) do “pool” de zoósporos resistentes após oito seleções em placas PYG contendo $250 \mu \mathrm{g} \cdot \mathrm{mL}^{-1}$ de higromicina B. O DNA genômico foi então submetido a um análise por PCR para a amplificação de um fragmento de 941 pb presente no gene de seleção hph. A Figura 28, a seguir, mostra que o gene marcador de resistência hph pode ser amplificado do DNA genômico de zoósporos resistentes, mas não no DNA genômico de células selvagens não transformadas, mas não do DNA genômico de células não transformadas.

A

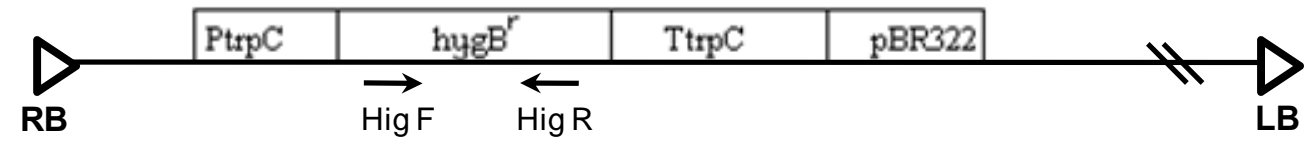

B

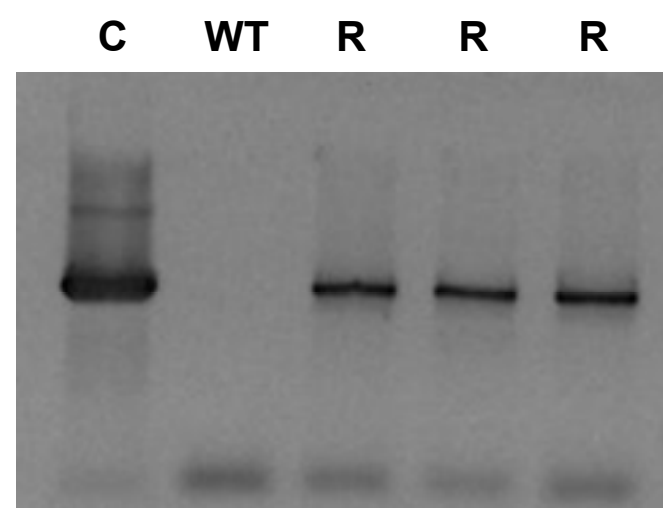

Figura 28: Análise do DNA genômico dos transformantes de B. emersonii por PCR. (A) Representação esquemática do cassete de resistência a higromicina B no T-DNA e a 
localização dos primers utilizados. (B) Foto do gel de agarose a 1\% corado com brometo de etídeo, mostrando a amplificação do cassete de resistência no DNA genômico do "pool" de zoósporos resistentes. $\mathrm{C}=$ controle positivo (plasmídeo pBINPLUS-Hph); WT=DNA genômico de células selvagens não transformadas; R=DNA genômico do "pool” de zoósporos resistentes. Primers utilizados (de $5^{\prime}$ a $3^{\prime}$ ): HigF GAAAAGTTCGACAGCGTCTCC; HigR - ACTTCTACACAGCCATCGGTC).

Infelizmente ainda não foi possível isolarmos um transformante individual estável, provavelmente devido à instabilidade da inserção do T-DNA no genoma do fungo. No entanto, nossos resultados com esta técnica mostram-se promissores e representam a primeira transformação de um Blastocladiomiceto relatada até o momento. 


\section{CONCLUSÕES}

- Este trabalho forneceu informações importantes sobre a expressão gênica global de Blastocladiella emersonii em resposta ao estresse de hipóxia. Observamos que 650 foram diferencialmente expressos em pelo menos uma das condições de estresse e que 534 deles se mostraram afetados (direta ou indiretamente) pela disponibilidade de oxigênio, uma vez que apresentaram uma recuperação da expressão (ou tendência à recuperação) aos níveis normais, quando as células foram reoxigenadas. Além de modular a expressão de diversos genes sem função conhecida, B. emersonii parece responder à hipóxia reajustando a expressão de genes responsáveis pela produção e consumo de energia.

- Pelo menos transcricionalmente, este fungo favorece o metabolismo anaeróbico, através da indução de genes que codificam enzimas da via glicolítica e lactato desidrogenase, ao passo que no ciclo do ácido cítrico, a maioria dos genes encontra-se reprimido ou não sofre alteração na expressão. Processos dispendiosos em energia como síntese protéica, metabolismo de aminoácidos, enovelamento de proteínas e transporte por membrana apresentaram perfis predominantemente reprimidos, quando em carência de oxigênio.

- Além das alterações morfológicas, o estresse de hipóxia leva a um aumento da captação de glicose do meio de cultura pelas células de B. emersonii, provavelmente devido à regulação positiva de genes que codificam enzimas da via glicolítica e da lactato desidrogenase.

- A análise estatística com o aplicativo BayGO revelou que as categorias mais representadas entre os genes com perfis induzidos em hipóxia gradual e/ou direta estão relacionadas a metabolismo de carboidratos, metabolismo de quitina, estrutura celular, homeostase redox e 
metabolismo de ácidos nucléicos. Dentre os genes com perfis reprimidos, as categorias mais representadas estão principalmente relacionadas a processos dispendiosos em energia, como enovelamento de proteínas, metabolismo de aminoácidos, transporte por membrana, além de processos moleculares dependentes de ligação a ATP.

- Quando comparamos a resposta transcricional de B. emersonii à hipóxia, com outros fungos como Trichoderma reesei ou Cryptococcus neoformans, observamos que a principal diferença encontrada consiste no metabolismo energético. Enquanto B. emersonii parece redirecionar seu metabolismo aeróbico para anaerobiose (fermentação), em Cryptococcus neoformans o metabolismo energético parece não ser muito regulado por hipóxia e em Trichoderma reesei ocorre uma drástica repressão da transcrição da maioria dos genes codificando enzimas tanto da via glicolítica quanto do ciclo do ácido cítrico. Este "Efeito Pasteur" observado transcricionalmente em B.emersonii assemelha-se mais ao que é observado em $S$. cerevisiae e em células de mamíferos submetidas à hipóxia. Como $S$. cerevisiae é um organismo anaeróbio facultativo, sugerimos que B.emersonii seja uma modelo de estudo mais conveniente para comparações com mamíferos.

- Mostramos que as semelhanças observadas entre os perfis transcricionais nos experimentos hipóxia e de carência de $\mathrm{Fe}^{2+}$, sugerem que estes estresses estão de alguma forma conectados, nos dando bons indícios de que o íon $\mathrm{Fe}^{2+}$ tem algum papel importante no mecanismo sensor de oxigênio e/ou de resposta a hipóxia em B. emersonii.

- O tratamento prévio de células submetidas à hipóxia com o antibiótico geldanamicina, um conhecido inibidor da HSP90, levou à diminuição da indução de certos genes de hipóxia, 
indicando que este fungo pode possuir algum mecanismo semelhante ao HIF1- $\alpha$ de mamíferos, que também é afetado por geldanamicina.

- Desenvolvemos um protocolo para transformação de $B$. emersonii mediada por Agrobacterium tumefasciens que se mostrou promissor. A transferência do T-DNA contendo um gene de resistência a higromicina $\mathrm{B}$, presente no vetor pBINPLUS-Hph, foi evidenciada pelo crescimento normal e esporulação das células transformadas, na presença do antibiótico e pela amplificação do gene de resistência no DNA genômico de células transformadas. 


\section{REFERÊNCIAS BIBLIOGRÁFICAS}

Alexandre, H., Rousseaux, I., and Charpentier, C. (1994) Relationship between ethanol tolerance, lipid composition and plasma membrane fluidity in Saccharomyces cerevisiae and Kloeckera apiculata. FEMS Microbiol Lett 124: 17-22.

Ausbel, F.M. (1992) Short Protocols in molecular biology: a compendium of methods from Current Protocols in Molecular Biology. Vol. 1 New York: Greene Pub Associates; Willey.

Azad, P., Zhou, D., Russo, E., and Haddad, G.G. (2009) Distinct mechanisms underlying tolerance to intermittent and constant hypoxia in Drosophila melanogaster. PLoS One 4: e5371.

Bartolini, E., Frigimelica, E., Giovinazzi, S., Galli, G., Shaik, Y., Genco, C., Welsch, J.A., Granoff, D.M., Grandi, G., and Grifantini, R. (2006) Role of FNR and FNRregulated, sugar fermentation genes in Neisseria meningitidis infection. Mol Microbiol 60: 963-972.

Becerra, M., Lombardia-Ferreira, L.J., Hauser, N.C., Hoheisel, J.D., Tizon, B., and Cerdan, M.E. (2002) The yeast transcriptome in aerobic and hypoxic conditions: effects of hap1, rox1, rox3 and srb10 deletions. Mol Microbiol 43: 545-555.

Bidmon, B., Endemann, M., Muller, T., Arbeiter, K., Herkner, K., and Aufricht, C. (2000) Heat shock protein-70 repairs proximal tubule structure after renal ischemia. Kidney Int 58: 2400-2407.

Bonaccorsi, E.D., Ferreira, A.J., Chambergo, F.S., Ramos, A.S., Mantovani, M.C., Farah, J.P., Sorio, C.S., Gombert, A.K., Tonso, A., and El-Dorry, H. (2006) Transcriptional response of the obligatory aerobe Trichoderma reesei to hypoxia and transient anoxia: implications for energy production and survival in the absence of oxygen. Biochemistry 45: 3912-3924.

Breunig, K.D., Bolotin-Fukuhara, M., Bianchi, M.M., Bourgarel, D., Falcone, C., Ferrero, I.I., Frontali, L., Goffrini, P., Krijger, J.J., Mazzoni, C., Milkowski, C., Steensma, H.Y., Wesolowski-Louvel, M., and Zeeman, A.M. (2000) Regulation of primary carbon metabolism in Kluyveromyces lactis. Enzyme Microb Technol 26: 771-780.

Bundock, P., den Dulk-Ras, A., Beijersbergen, A., and Hooykaas, P.J. (1995) Transkingdom T-DNA transfer from Agrobacterium tumefaciens to Saccharomyces cerevisiae. EMBO J 14: 3206-3214.

Cao, P., and Moini, M. (1998) Analysis of peptides, proteins, protein digests, and whole human blood by capillary electrophoresis/electrospray ionization-mass spectrometry using an in-capillary electrode sheathless interface. J Am Soc Mass Spectrom 9: 1081-1088.

Carratu, L., Franceschelli, S., Pardini, C.L., Kobayashi, G.S., Horvath, I., Vigh, L., and Maresca, B. (1996) Membrane lipid perturbation modifies the set point of the temperature of heat shock response in yeast. Proc Natl Acad Sci U S A 93: 38703875.

Castello, P.R., David, P.S., McClure, T., Crook, Z., and Poyton, R.O. (2006) Mitochondrial cytochrome oxidase produces nitric oxide under hypoxic conditions: implications for oxygen sensing and hypoxic signaling in eukaryotes. Cell Metab 3: 277-287.

Chang, W., Song, B.W., Lim, S., Song, H., Shim, C.Y., Cha, M.J., Ahn, D.H., Jung, Y.G., Lee, D.H., Chung, J.H., Choi, K.D., Lee, S.K., Chung, N., Jang, Y., and Hwang, K.C. (2009) Mesenchymal stem cells pretreated with delivered hph-1-hsp70 protein 
are protected from hypoxia-mediated cell death and rescue heart functions from myocardial injury. Stem Cells 27: 2283-2292.

Chang, Y.C., Bien, C.M., Lee, H., Espenshade, P.J., and Kwon-Chung, K.J. (2007) Sre1p, a regulator of oxygen sensing and sterol homeostasis, is required for virulence in Cryptococcus neoformans. Mol Microbiol 64: 614-629.

Chen, X., Stone, M., Schlagnhaufer, C., and Romaine, C.P. (2000) A fruiting body tissue method for efficient Agrobacterium-mediated transformation of Agaricus bisporus. Appl Environ Microbiol 66: 4510-4513.

Chun, C.D., Liu, O.W., and Madhani, H.D. (2007) A link between virulence and homeostatic responses to hypoxia during infection by the human fungal pathogen Cryptococcus neoformans. PLoS Pathog 3: e22.

Cleveland, D.W., and Sullivan, K.F. (1985) Molecular biology and genetics of tubulin. Annu Rev Biochem 54: 331-365.

Connolly, E., Braunstein, S., Formenti, S., and Schneider, R.J. (2006) Hypoxia inhibits protein synthesis through a 4E-BP1 and elongation factor 2 kinase pathway controlled by mTOR and uncoupled in breast cancer cells. Mol Cell Biol 26: $3955-$ 3965.

Cronan, J.E., Jr. (2002) Phospholipid modifications in bacteria. Curr Opin Microbiol 5: 202205.

de Groot, M.J., Bundock, P., Hooykaas, P.J., and Beijersbergen, A.G. (1998) Agrobacterium tumefaciens-mediated transformation of filamentous fungi. Nat Biotechnol 16: 839842.

Espenshade, P.J. (2006) SREBPs: sterol-regulated transcription factors. J Cell Sci 119: 973976.

Farmer, S.R., Robinson, G.S., Mbangkollo, D., Bond, J.F., Knight, G.B., Fenton, M.J., and Berkowitz, E.M. (1986) Differential expression of the beta-tubulin multigene family during rat brain development. Ann N Y Acad Sci 466: 41-50.

Ferguson, L.R., and von Borstel, R.C. (1992) Induction of the cytoplasmic 'petite' mutation by chemical and physical agents in Saccharomyces cerevisiae. Mutat Res 265: 103148.

Fiehn, O., Kopka, J., Dormann, P., Altmann, T., Trethewey, R.N., and Willmitzer, L. (2000a) Metabolite profiling for plant functional genomics. Nat Biotechnol 18: 11571161.

Fiehn, O., Kopka, J., Trethewey, R.N., and Willmitzer, L. (2000b) Identification of uncommon plant metabolites based on calculation of elemental compositions using gas chromatography and quadrupole mass spectrometry. Anal Chem 72: 3573-3580.

Fraenkel, D.G. (1992) Genetics and intermediary metabolism. Annu Rev Genet 26: 159-177.

Georg, R.C., and Gomes, S.L. (2007) Transcriptome analysis in response to heat shock and cadmium in the aquatic fungus Blastocladiella emersonii. Eukaryot Cell 6: 1053 1062.

Georg, R.C., Stefani, R.M., and Gomes, S.L. (2009) Environmental stresses inhibit splicing in the aquatic fungus Blastocladiella emersonii. BMC Microbiol 9: 231.

Georg Rde, C., and Gomes, S.L. (2007) Comparative expression analysis of members of the Hsp70 family in the chytridiomycete Blastocladiella emersonii. Gene 386: 24-34.

Goodman, A., Goode, B.L., Matsudaira, P., and Fink, G.R. (2003) The Saccharomyces cerevisiae calponin/transgelin homolog Scp1 functions with fimbrin to regulate stability and organization of the actin cytoskeleton. Mol Biol Cell 14: 2617-2629.

Goodman, L.A., and Kruskal, W.H. (1954) Measures of association for cross classifications. $J$ Am Stat Assoc 49: 732-764. 
Gottschalk, W.K., and Sonneborn, D.R. (1982) Phenotypic dissections of the Blastocladiella emersonii zoospore's developmental choice. Dev Biol 93: 165-180.

Guzy, R.D., Mack, M.M., and Schumacker, P.T. (2007) Mitochondrial complex III is required for hypoxia-induced ROS production and gene transcription in yeast. Antioxid Redox Signal 9: 1317-1328.

Helmlinger, G., Yuan, F., Dellian, M., and Jain, R.K. (1997) Interstitial pH and pO2 gradients in solid tumors in vivo: high-resolution measurements reveal a lack of correlation. Nat Med 3: 177-182.

Hibbett, D.S., Binder, M., Bischoff, J.F., Blackwell, M., Cannon, P.F., Eriksson, O.E., Huhndorf, S., James, T., Kirk, P.M., Lucking, R., Thorsten Lumbsch, H., Lutzoni, F., Matheny, P.B., McLaughlin, D.J., Powell, M.J., Redhead, S., Schoch, C.L., Spatafora, J.W., Stalpers, J.A., Vilgalys, R., Aime, M.C., Aptroot, A., Bauer, R., Begerow, D., Benny, G.L., Castlebury, L.A., Crous, P.W., Dai, Y.C., Gams, W., Geiser, D.M., Griffith, G.W., Gueidan, C., Hawksworth, D.L., Hestmark, G., Hosaka, K., Humber, R.A., Hyde, K.D., Ironside, J.E., Koljalg, U., Kurtzman, C.P., Larsson, K.H., Lichtwardt, R., Longcore, J., Miadlikowska, J., Miller, A., Moncalvo, J.M., Mozley-Standridge, S., Oberwinkler, F., Parmasto, E., Reeb, V., Rogers, J.D., Roux, C., Ryvarden, L., Sampaio, J.P., Schussler, A., Sugiyama, J., Thorn, R.G., Tibell, L., Untereiner, W.A., Walker, C., Wang, Z., Weir, A., Weiss, M., White, M.M., Winka, K., Yao, Y.J., and Zhang, N. (2007) A higher-level phylogenetic classification of the Fungi. Mycol Res 111: 509-547.

Higgins, C.F. (1992) ABC transporters: from microorganisms to man. Annu Rev Cell Biol 8: 67-113.

Hochachka, P.W., and Lutz, P.L. (2001) Mechanism, origin, and evolution of anoxia tolerance in animals. Comp Biochem Physiol B Biochem Mol Biol 130: 435-459.

Hoekema, A., Hirsch, P.R., Hooykaas, P.J., and Schilperoort, R.A. (1983) A binary vector strategy based on separation of vir-region and T-region of the Agrobacterium tumefaciens Ti-plasmid. Nature 303: 179-180.

Hood, E.E., Gelvin, S.B., Melchers, L.S., and Hoekema, A. (1993) New Agrobacterium helper plasmids for gene transfer to plants. Transgenic Res. 2: 208-218.

Hooykaas, P.J.J., and Beijersbergen, A.G.M. (1994) The virulence system of Agrobacterium tumefaciens. Annual Review of Phytopathology 32: 157-181.

Huang, W.J., Xia, L.M., Zhu, F., Huang, B., Zhou, C., Zhu, H.F., Wang, B., Chen, B., Lei, P., and Shen, G.X. (2009) Transcriptional upregulation of HSP70-2 by HIF-1 in cancer cells in response to hypoxia. Int J Cancer 124: 298-305.

Hughes, A.L., Todd, B.L., and Espenshade, P.J. (2005) SREBP pathway responds to sterols and functions as an oxygen sensor in fission yeast. Cell 120: 831-842.

Husson, A., Brasse-Lagnel, C., Fairand, A., Renouf, S., and Lavoinne, A. (2003) Argininosuccinate synthetase from the urea cycle to the citrulline-NO cycle. Eur $J$ Biochem 270: 1887-1899.

Ideker, T., Thorsson, V., Ranish, J.A., Christmas, R., Buhler, J., Eng, J.K., Bumgarner, R., Goodlett, D.R., Aebersold, R., and Hood, L. (2001) Integrated genomic and proteomic analyses of a systematically perturbed metabolic network. Science 292: 929-934.

Inderlied, C.B., and Sypherd, P.S. (1978) Glucose metabolism and dimorphism in Mucor. $J$ Bacteriol 133: 1282-1286.

Jefferies, K.C., Cipriano, D.J., and Forgac, M. (2008) Function, structure and regulation of the vacuolar (H+)-ATPases. Arch Biochem Biophys 476: 33-42. 
Jiang, Y., Vasconcelles, M.J., Wretzel, S., Light, A., Martin, C.E., and Goldberg, M.A. (2001) MGA2 is involved in the low-oxygen response element-dependent hypoxic induction of genes in Saccharomyces cerevisiae. Mol Cell Biol 21: 6161-6169.

Johnston, M. (1999) Feasting, fasting and fermenting. Glucose sensing in yeast and other cells. Trends Genet 15: 29-33.

Kandasamy, P., Vemula, M., Oh, C.S., Chellappa, R., and Martin, C.E. (2004) Regulation of unsaturated fatty acid biosynthesis in Saccharomyces: the endoplasmic reticulum membrane protein, Mga2p, a transcription activator of the OLE1 gene, regulates the stability of the OLE1 mRNA through exosome-mediated mechanisms. J Biol Chem 279: 36586-36592.

Klose, R.J., Kallin, E.M., and Zhang, Y. (2006) JmjC-domain-containing proteins and histone demethylation. Nat Rev Genet 7: 715-727.

Koide, T., Salem-Izacc, S.M., Gomes, S.L., and Vencio, R.Z. (2006) SpotWhatR: a userfriendly microarray data analysis system. Genet Mol Res 5: 93-107.

Kunik, T., Tzfira, T., Kapulnik, Y., Gafni, Y., Dingwall, C., and Citovsky, V. (2001) Genetic transformation of HeLa cells by Agrobacterium. Proc Natl Acad Sci U S A 98: $1871-1876$.

Kwast, K.E., Burke, P.V., and Poyton, R.O. (1998) Oxygen sensing and the transcriptional regulation of oxygen-responsive genes in yeast. J Exp Biol 201: 1177-1195.

Kwast, K.E., Burke, P.V., Staahl, B.T., and Poyton, R.O. (1999) Oxygen sensing in yeast: evidence for the involvement of the respiratory chain in regulating the transcription of a subset of hypoxic genes. Proc Natl Acad Sci U S A 96: 5446-5451.

Kwast, K.E., Lai, L.C., Menda, N., James, D.T., 3rd, Aref, S., and Burke, P.V. (2002) Genomic analyses of anaerobically induced genes in Saccharomyces cerevisiae: functional roles of Rox 1 and other factors in mediating the anoxic response. $J$ Bacteriol 184: 250-265.

Laabs, T.L., Markwardt, D.D., Slattery, M.G., Newcomb, L.L., Stillman, D.J., and Heideman, W. (2003) ACE2 is required for daughter cell-specific G1 delay in Saccharomyces cerevisiae. Proc Natl Acad Sci U S A 100: 10275-10280.

Lai, L.C., Kosorukoff, A.L., Burke, P.V., and Kwast, K.E. (2006) Metabolic-state-dependent remodeling of the transcriptome in response to anoxia and subsequent reoxygenation in Saccharomyces cerevisiae. Eukaryot Cell 5: 1468-1489.

Liu, Y.V., and Semenza, G.L. (2007) RACK1 vs. HSP90: competition for HIF-1 alpha degradation vs. stabilization. Cell Cycle 6: 656-659.

Lovett, J.S. (1975) Growth and differentiation of the water mold Blastocladiella emersonii: cytodifferentiation and the role of ribonucleic acid and protein synthesis. Bacteriol Rev 39: 345-404.

Lu, A., Ran, R., Parmentier-Batteur, S., Nee, A., and Sharp, F.R. (2002) Geldanamycin induces heat shock proteins in brain and protects against focal cerebral ischemia. $J$ Neurochem 81: 355-364.

Maia, J.C., and Camargo, E.P. (1974) c-AMP phosphodiesterase activity during growth and differentiation in Blastocladiella emersonii. Cell Differ 3: 147-155.

Maia, J.C., Gomes, S.L., and Mennucci, L. (1979) Induction of germination in Blastocladiella emersonii by cyclic AMP and inhibitors of cyclic AMP phosphodiesterase. Arch Biol Med Exp (Santiago) 12: 407-410.

Marin-Hernandez, A., Gallardo-Perez, J.C., Ralph, S.J., Rodriguez-Enriquez, S., and Moreno-Sanchez, R. (2009) HIF-1alpha modulates energy metabolism in cancer cells by inducing over-expression of specific glycolytic isoforms. Mini Rev Med Chem 9: 1084-1101. 
Markuszewski, M.J., Otsuka, K., Terabe, S., Matsuda, K., and Nishioka, T. (2003) Analysis of carboxylic acid metabolites from the tricarboxylic acid cycle in Bacillus subtilis cell extract by capillary electrophoresis using an indirect photometric detection method. J Chromatogr A 1010: 113-121.

Markuszewski, M.J., Szczykowska, M., Siluk, D., and Kaliszan, R. (2005) Human red blood cells targeted metabolome analysis of glycolysis cycle metabolites by capillary electrophoresis using an indirect photometric detection method. J Pharm Biomed Anal 39: 636-642.

Matthysse, A.G. (2007) The Genus Agrobacterium. In The Prokaryotes: Proteobacteria: alpha and beta subclasses. Vol. 5. Dworkin, M. and Falkow, S. (eds). New York: Springer New York, pp. 91-114.

Mertens, E., Larondelle, Y., and Hers, H.G. (1990) Induction of Pyrophosphate:Fructose 6Phosphate 1-Phosphotransferase by Anoxia in Rice Seedlings. Plant Physiol 93: 584587.

Mertens, E. (1991) Pyrophosphate-dependent phosphofructokinase, an anaerobic glycolytic enzyme? FEBS Lett 285: 1-5.

Michielse, C.B., Hooykaas, P.J., van den Hondel, C.A., and Ram, A.F. (2005) Agrobacterium-mediated transformation as a tool for functional genomics in fungi. Curr Genet 48: 1-17.

Nakagawa, Y., Ueda, A., Kaneko, Y., and Harashima, S. (2003) Merging of multiple signals regulating delta9 fatty acid desaturase gene transcription in Saccharomyces cerevisiae. Mol Genet Genomics 269: 370-380.

Nissen, T.L., Schulze, U., Nielsen, J., and Villadsen, J. (1997) Flux distributions in anaerobic, glucose-limited continuous cultures of Saccharomyces cerevisiae. Microbiology 143 ( Pt 1): 203-218.

Ntambi, J.M. (1999) Regulation of stearoyl-CoA desaturase by polyunsaturated fatty acids and cholesterol. J Lipid Res 40: 1549-1558.

Papadopoulos, M.C., Sun, X.Y., Cao, J., Mivechi, N.F., and Giffard, R.G. (1996) Overexpression of HSP-70 protects astrocytes from combined oxygen-glucose deprivation. Neuroreport 7: 429-432.

Pasteur, L. (1861) Expériences et vues nouvelles sur la nature des fermentations. Comp. Rend. Acad. Sci. 52: 1260-1264.

Pfeiffer, T., Schuster, S., and Bonhoeffer, S. (2001) Cooperation and competition in the evolution of ATP-producing pathways. Science 292: 504-507.

Plumier, J.C., Krueger, A.M., Currie, R.W., Kontoyiannis, D., Kollias, G., and Pagoulatos, G.N. (1997) Transgenic mice expressing the human inducible Hsp70 have hippocampal neurons resistant to ischemic injury. Cell Stress Chaperones 2: 162167.

Pugliese, L., Georg, R.C., Fietto, L.G., and Gomes, S.L. (2008) Expression of genes encoding cytosolic and endoplasmic reticulum HSP90 proteins in the aquatic fungus Blastocladiella emersonii. Gene 411: 59-68.

Quackenbush, J. (2001) Computational analysis of microarray data. Nat Rev Genet 2: 418427.

Raamsdonk, L.M., Teusink, B., Broadhurst, D., Zhang, N., Hayes, A., Walsh, M.C., Berden, J.A., Brindle, K.M., Kell, D.B., Rowland, J.J., Westerhoff, H.V., van Dam, K., and Oliver, S.G. (2001) A functional genomics strategy that uses metabolome data to reveal the phenotype of silent mutations. Nat Biotechnol 19: 45-50.

Rajdev, S., Hara, K., Kokubo, Y., Mestril, R., Dillmann, W., Weinstein, P.R., and Sharp, F.R. (2000) Mice overexpressing rat heat shock protein 70 are protected against cerebral infarction. Ann Neurol 47: 782-791. 
Reeves, R.E., South, D.J., Blytt, H.J., and Warren, L.G. (1974) Pyrophosphate:D-fructose 6phosphate 1-phosphotransferase. A new enzyme with the glycolytic function of 6phosphofructokinase. J Biol Chem 249: 7737-7741.

Ribichich, K.F., Salem-Izacc, S.M., Georg, R.C., Vencio, R.Z., Navarro, L.D., and Gomes, S.L. (2005) Gene discovery and expression profile analysis through sequencing of expressed sequence tags from different developmental stages of the chytridiomycete Blastocladiella emersonii. Eukaryot Cell 4: 455-464.

Ribichich, K.F., Georg, R.C., and Gomes, S.L. (2006) Comparative EST analysis provides insights into the basal aquatic fungus Blastocladiella emersonii. BMC Genomics 7: 177.

Salem-Izacc, S.M., Koide, T., Vencio, R.Z., and Gomes, S.L. (2009) Global gene expression analysis during germination in the chytridiomycete Blastocladiella emersonii. Eukaryot Cell 8: 170-180.

Sambrook, J., Fritsch,E.F., \& Maniatis,T. (1989) Molecular Cloning: A Laboratory Manual. Cold Spring Harbour, NY.

Schild, L., Reinheckel, T., Reiser, M., Horn, T.F., Wolf, G., and Augustin, W. (2003) Nitric oxide produced in rat liver mitochondria causes oxidative stress and impairment of respiration after transient hypoxia. FASEB J 17: 2194-2201.

Semenza, G.L. (2007) Hypoxia-inducible factor 1 (HIF-1) pathway. Sci STKE 2007: cm8.

Setiadi, E.R., Doedt, T., Cottier, F., Noffz, C., and Ernst, J.F. (2006) Transcriptional response of Candida albicans to hypoxia: linkage of oxygen sensing and Efglpregulatory networks. J Mol Biol 361: 399-411.

Soga, T., and Heiger, D.N. (2000) Amino acid analysis by capillary electrophoresis electrospray ionization mass spectrometry. Anal Chem 72: 1236-1241.

Soga, T., Ueno, Y., Naraoka, H., Matsuda, K., Tomita, M., and Nishioka, T. (2002a) Pressure-assisted capillary electrophoresis electrospray ionization mass spectrometry for analysis of multivalent anions. Anal Chem 74: 6224-6229.

Soga, T., Ueno, Y., Naraoka, H., Ohashi, Y., Tomita, M., and Nishioka, T. (2002b) Simultaneous determination of anionic intermediates for Bacillus subtilis metabolic pathways by capillary electrophoresis electrospray ionization mass spectrometry. Anal Chem 74: 2233-2239.

Soga, T., Ohashi, Y., Ueno, Y., Naraoka, H., Tomita, M., and Nishioka, T. (2003) Quantitative metabolome analysis using capillary electrophoresis mass spectrometry. J Proteome Res 2: 488-494.

Soll, D.R., and Sonneborn, D.R. (1972) Zoospore germination in Blastocladiella emersonii. IV. Ion control over cell differentiation. J Cell Sci 10: 315-333.

Spinnler, H.E., Ginies, C., Khan, J.A., and Vulfson, E.N. (1996) Analysis of metabolic pathways by the growth of cells in the presence of organic solvents. Proc Natl Acad Sci U S A 93: 3373-3376.

Staben, C., Jensen, B., Singer, M., Pollock, J., Schechtman, M., Kinsey, J., and Selker, E. (1989) Use of a bacterial hygromycin B resistance gene as a dominant marker in Neurospora crassa transformation. Fungal Genet. Newsl. 36: 79-81.

Stecyk, J.A., Stenslokken, K.O., Farrell, A.P., and Nilsson, G.E. (2004) Maintained cardiac pumping in anoxic crucian carp. Science 306: 77.

Stewart, L.C., and Yaffe, M.P. (1991) A role for unsaturated fatty acids in mitochondrial movement and inheritance. J Cell Biol 115: 1249-1257.

Tanaka, Y., Higashi, T., Rakwal, R., Wakida, S., and Iwahashi, H. (2008) Development of a capillary electrophoresis-mass spectrometry method using polymer capillaries for metabolomic analysis of yeast. Electrophoresis 29: 2016-2023. 
Taylor, C.T. (2008) Mitochondria and cellular oxygen sensing in the HIF pathway. Biochem J 409: 19-26.

ter Linde, J.J., Liang, H., Davis, R.W., Steensma, H.Y., van Dijken, J.P., and Pronk, J.T. (1999) Genome-wide transcriptional analysis of aerobic and anaerobic chemostat cultures of Saccharomyces cerevisiae. J Bacteriol 181: 7409-7413.

Tikhonova, N.S., Moskaleva, O.S., Margulis, B.A., and Guzhova, I.V. (2008) [Molecular chaperone Hsp70 protects neuroblastoma SK-N-SH cells from hypoxic stress]. Tsitologiia 50: 467-472.

Todd, B.L., Stewart, E.V., Burg, J.S., Hughes, A.L., and Espenshade, P.J. (2006) Sterol regulatory element binding protein is a principal regulator of anaerobic gene expression in fission yeast. Mol Cell Biol 26: 2817-2831.

Valdez, L.B., Zaobornyj, T., Alvarez, S., Bustamante, J., Costa, L.E., and Boveris, A. (2004) Heart mitochondrial nitric oxide synthase. Effects of hypoxia and aging. Mol Aspects Med 25: 49-59.

van Engelen, F.A., Molthoff, J.W., Conner, A.J., Nap, J.P., Pereira, A., and Stiekema, W.J. (1995) pBINPLUS: an improved plant transformation vector based on pBIN19. Transgenic Res. 4: 288-290.

Vasconcelles, M.J., Jiang, Y., McDaid, K., Gilooly, L., Wretzel, S., Porter, D.L., Martin, C.E., and Goldberg, M.A. (2001) Identification and characterization of a low oxygen response element involved in the hypoxic induction of a family of Saccharomyces cerevisiae genes. Implications for the conservation of oxygen sensing in eukaryotes. $J$ Biol Chem 276: 14374-14384.

Vaulont, S., Vasseur-Cognet, M., and Kahn, A. (2000) Glucose regulation of gene transcription. J Biol Chem 275: 31555-31558.

Vencio, R.Z., and Koide, T. (2005) HTself: self-self based statistical test for low replication microarray studies. DNA Res 12: 211-214.

Vencio, R.Z., Koide, T., Gomes, S.L., and Pereira, C.A. (2006) BayGO: Bayesian analysis of ontology term enrichment in microarray data. BMC Bioinformatics 7: 86.

Vicencio, A., Bidmon, B., Ryu, J., Reidy, K., Thulin, G., Mann, A., Gaudio, K.M., Kashgarian, M., and Siegel, N.J. (2003) Developmental expression of HSP-72 and ischemic tolerance of the immature kidney. Pediatr Nephrol 18: 85-91.

Vieira, A.L., and Gomes, S.L. (2009) Global Gene Expression Analysis During Sporulation of the Aquatic Fungus Blastocladiella emersonii. Eukaryot Cell (Submetido).

Vieira, A.L., Linares, E., Augusto, O., and Gomes, S.L. (2009) Evidence of a Ca(2+)(*)NO-cGMP signaling pathway controlling zoospore biogenesis in the aquatic fungus Blastocladiella emersonii. Fungal Genet Biol 46: 575-584.

Vogt, M., Puntschart, A., Geiser, J., Zuleger, C., Billeter, R., and Hoppeler, H. (2001) Molecular adaptations in human skeletal muscle to endurance training under simulated hypoxic conditions. J Appl Physiol 91: 173-182.

Webster, K.A. (2003) Evolution of the coordinate regulation of glycolytic enzyme genes by hypoxia. J Exp Biol 206: 2911-2922.

Winum, J.Y., Rami, M., Scozzafava, A., Montero, J.L., and Supuran, C. (2008) Carbonic anhydrase IX: a new druggable target for the design of antitumor agents. Med Res Rev 28: 445-463.

Wood, G.E., Khelef, N., Guiso, N., and Friedman, R.L. (1998) Identification of Btrregulated genes using a titration assay. Search for a role for this transcriptional regulator in the growth and virulence of Bordetella pertussis. Gene 209: 51-58.

Yang, Y.H., Dudoit, S., Luu, P., Lin, D.M., Peng, V., Ngai, J., and Speed, T.P. (2002) Normalization for cDNA microarray data: a robust composite method addressing single and multiple slide systematic variation. Nucleic Acids Res 30: e15. 
Zhang, R., Zhou, L., Li, Q., Liu, J., Yao, W., and Wan, H. (2009) Up-Regulation of two actin-associated proteins prompts pulmonary artery smooth muscle cell migration under hypoxia. Am J Respir Cell Mol Biol 41: 467-475.

Zhu, J., Oger, P.M., Schrammeijer, B., Hooykaas, P.J., Farrand, S.K., and Winans, S.C. (2000) The bases of crown gall tumorigenesis. J Bacteriol 182: 3885-3895.

Zitomer, R.S., Carrico, P., and Deckert, J. (1997) Regulation of hypoxic gene expression in yeast. Kidney Int 51: 507-513.

Zupan, J., Muth, T.R., Draper, O., and Zambryski, P. (2000) The transfer of DNA from agrobacterium tumefaciens into plants: a feast of fundamental insights. Plant $J$ 23: 11-28.

Zwiers, L.H., and De Waard, M.A. (2001) Efficient Agrobacterium tumefaciens-mediated gene disruption in the phytopathogen Mycosphaerella graminicola. Curr Genet 39: 388-393. 


\section{MATERIAL SUPLEMENTAR}

Tabela S 1: Lista completa dos genes diferencialmente expressos em hipóxia gradual e direta. Os valores representam a razão de expressão (teste/C70). As setas indicam os perfis de indução (para cima) ou repressão (para baixo).

\begin{tabular}{|c|c|c|c|c|c|c|c|c|c|c|c|c|c|c|c|}
\hline \multirow[b]{2}{*}{ Clone ID } & \multirow[b]{2}{*}{ SwissProt } & \multirow[b]{2}{*}{ Anotação } & \multirow[b]{2}{*}{ 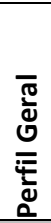 } & \multicolumn{4}{|c|}{ Hipóxia Direta } & \multicolumn{8}{|c|}{ Hipóxia Gradual } \\
\hline & & & & $\begin{array}{c}\text { न } \\
\text { - }\end{array}$ & $\begin{array}{l}\text { ம } \\
\text { 건 }\end{array}$ & 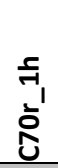 & 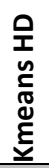 & $\stackrel{0}{0}$ & ભ & 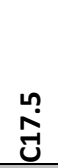 & 约 & ت & 운 & ডั̀ & 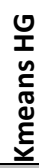 \\
\hline \multicolumn{16}{|c|}{ Metabolismo de Aminoácidos } \\
\hline BeZSPN04C10 & Q9P7L5 & ornithine-oxo-acid transaminase, putative & $\downarrow$ & 0.7 & 0.6 & 1.2 & 1 & & & & & & & & \\
\hline BeE120N30H05 & Q7RV8 & Arginase & $\downarrow$ & 0.5 & 0.9 & 1.1 & 1 & 1.1 & 1.1 & 0.8 & 0.6 & 0.4 & 0.4 & 1.1 & 1 \\
\hline BeE30N08H12 & P9497 & 2-isopropylmalate synthase & $\downarrow$ & 0.8 & 0.9 & 1.4 & 1 & 1.0 & 1.2 & 1.0 & 1.0 & 0.7 & 0.7 & 1.2 & 2 \\
\hline BeE30N15B02 & & cysteine synthase & $\downarrow$ & 0.8 & 0.7 & 1.1 & 1 & & 0.9 & 1.1 & 1.1 & & 0.5 & 0.7 & 2 \\
\hline BeE30N19D09 & Q7VVU3 & $\begin{array}{l}\text { 5-methyltetrahydropteroyltriglutamate--homocysteine } \\
\text { methyltransferase }\end{array}$ & $\downarrow$ & 0.2 & 0.6 & 2.1 & 2 & 1.0 & 0.4 & 0.4 & 0.3 & 0.1 & 0.1 & 0.4 & 8 \\
\hline BeE60H28B12 & Q96VZ6 & Acetolactate synthase Ilv2 & $\downarrow$ & 0.4 & 0.5 & 2.9 & 1 & 1.0 & 1.2 & 1.5 & 1.3 & 0.3 & 0.3 & 1.5 & 1 \\
\hline BeE60N07B05 & Q9NAE2 & Probable urocanate hydratase & $\downarrow$ & 0.6 & 0.8 & 0.9 & 1 & 1.1 & 1.1 & 1.0 & 0.9 & 0.6 & 0.8 & 0.9 & 2 \\
\hline BeE90D12G12 & P48611 & 6-pyruvoyl tetrahydropterin synthase & $\downarrow$ & 1.0 & 0.7 & 1.4 & 1 & 1.0 & 1.1 & 0.9 & 0.8 & 0.6 & 1.3 & 0.6 & 5 \\
\hline BeG120N15B05 & Q12642 & S-adenosylmethionine synthetase (Fragment) & $\downarrow$ & 0.3 & & & & 1.0 & 0.5 & 0.5 & 0.5 & 0.1 & 0.2 & 0.6 & 8 \\
\hline BeZSPN16H02 & P1869 & Aspartokinase & $\downarrow$ & 0.6 & 0.9 & 1.2 & 1 & 0.9 & 0.9 & 1.0 & 0.9 & 0.5 & 0.5 & 1.4 & 1 \\
\hline BeG30N04E01 & Q8JHX9 & Glutamate dehydrogenase 3 & $\downarrow$ & & & & & 1.2 & 0.8 & & 0.5 & & 0.6 & 0.8 & 2 \\
\hline BeZSPN14H05 & & histidinol phosphate aminotransferase & $\downarrow$ & 0.7 & 1.0 & 1.4 & 1 & 1.0 & 0.7 & 0.7 & 0.7 & 0.3 & 0.2 & 0.7 & 1 \\
\hline BeE60C11F11 & P22768 & Argininosuccinate synthase & $\uparrow$ & 0.9 & 1.6 & 1.1 & 3 & 1.0 & 1.8 & 1.2 & 1.2 & 1.6 & 1.7 & 0.4 & 6 \\
\hline BeG90N02C03 & P78568 & Delta-1-pyrroline-5-carboxylate dehydrogenase & $\uparrow$ & 1.7 & 2.1 & 1.2 & 3 & 1.1 & 1.1 & 0.9 & 1.0 & 1.7 & 2.1 & 1.0 & 6 \\
\hline BeG90N10B05 & Q8KCK4 & Glutamine synthetase & $\uparrow$ & 1.2 & 1.7 & 1.3 & 3 & 1.0 & 1.1 & 0.9 & 1.2 & 1.3 & 1.9 & 1.0 & 6 \\
\hline BeZSPN09E10 & 042615 & Threonine dehydratase, mitochondrial precur & & 0.9 & & 0.5 & & & & & & & & & \\
\hline BeE60C27C06 & Q9C2U8 & NAD+ dependent glutamate dehydrogenase & & 1.1 & 0.8 & 0.4 & 4 & & 0.9 & 1.0 & 0.9 & 1.1 & 1.0 & 0.6 & 5 \\
\hline BeE90D18B03 & & NAD+ dependent glutamate dehydrogenase & & 1.3 & 0.8 & 0.4 & 4 & 1.0 & 0.9 & 0.7 & 0.8 & 1.1 & 1.3 & 0.5 & 5 \\
\hline BeG120N26D12 & Q9Y8G5 & NAD-specific glutamate dehydrogenase & & 1.4 & 0.8 & 0.5 & 4 & 1.0 & 1.0 & 0.8 & 0.9 & 1.0 & 1.4 & 0.6 & 5 \\
\hline BeE60N07C12 & Q7ZWF5 & Similar to glutamate oxaloacetate transaminase & & 1.1 & 1.2 & 1.5 & 3 & 1.0 & 1.1 & 1.3 & 1.1 & 0.8 & 0.7 & 0.8 & 2 \\
\hline BeG90N07G03 & & glutamate dehydrogenase, $N A D(P)+$ & & 1.2 & & 0.2 & & & 0.9 & 0.8 & 0.6 & 0.8 & 0.9 & 0.7 & 5 \\
\hline BeE60C15E06 & & glutamine synthetase & & 0.9 & & 0.5 & & & & & & & & & \\
\hline BeG30N19E04 & P87185 & Cysteine desulfurase, mitochondrial precursor & & 0.9 & 0.9 & 1.4 & 1 & & & & & & & & \\
\hline BeE60H21G01 & & homogentisate 1,2-dioxygenase & & & & & & 1.0 & 1.4 & 1.2 & 1.3 & 0.9 & 1.0 & 0.9 & 4 \\
\hline BeE60N06A04 & Q7SD77 & Phospho-2-keto-3-deoxyheptonate aldolase & & & & & & 1.1 & 1.1 & 1.1 & 1.2 & 0.8 & 0.9 & 1.5 & 4 \\
\hline BeG30N02C12 & Q93HL2 & Tyrosinase & & & & & & 0.9 & 1.4 & 1.1 & 1.2 & 1.5 & 1.2 & 1.3 & 4 \\
\hline \multirow[t]{2}{*}{ BeG60N02D07 } & & glycine cleavage system H protein (16.0 kD) & & & & & & 1.0 & 1.0 & 0.8 & 1.0 & 1.0 & 1.0 & 0.6 & 5 \\
\hline & & Ciclo Celular & & & & & & & & & & & & & \\
\hline BeG30N12D04 & Q2533 & Cyclin-dependent kinases regulatory subunit & $\downarrow$ & 0.7 & 0.9 & 1.1 & 1 & & & & & & & & \\
\hline BeE120N32A08 & P7862 & Septin B & $\uparrow$ & 1.0 & 1.8 & 1.2 & 3 & 0.9 & 1.4 & 1.0 & 1.1 & 1.1 & 1.4 & 0.8 & 6 \\
\hline BeE60N18D05 & & cyclin-dependent protein kinase PHOB & $\uparrow$ & & & & & 1.1 & 1.1 & 0.9 & 1.1 & 1.4 & 1.6 & 1.1 & 6 \\
\hline BeG30N08C06 & Q9C1M3 & Septin & $\uparrow$ & & & & & 1.0 & 1.1 & 1.0 & 0.9 & 1.2 & 1.7 & 1.0 & 6 \\
\hline BeZSPN15D07 & P34991 & S-phase kinase-associated protein $1 \mathrm{~A}$ & $\uparrow$ & & & & & 1.0 & 1.0 & 1.0 & 1.2 & 1.5 & 1.4 & 1.0 & 6 \\
\hline \multirow[t]{2}{*}{$\mathrm{BeE60H} 26 \mathrm{CO} 8$} & Q9P3A7 & Cell division cycle protein 48 homolog & & & & & & 1.0 & 0.9 & 0.9 & 1.1 & 0.9 & 1.0 & 0.7 & 5 \\
\hline & & Parede Celular & & & & & & & & & & & & & \\
\hline BeE60N10E05 & Q99447 & Ethanolamine-phosphate cytidylyltransferase & $\downarrow$ & & & & & 1.0 & 1.1 & 0.8 & 0.9 & 0.6 & 0.6 & 0.9 & 2 \\
\hline BeG90N10G04 & P87073 & Chitin synthase 1 & $\downarrow$ & & & & & 1.2 & 0.8 & 0.8 & 0.5 & 0.6 & 0.6 & 0.7 & 2 \\
\hline BeE90N16E04 & Q7X5L8 & Chitinase Chi80 precursor & $\uparrow$ & 1.3 & 1.5 & 1.0 & 3 & & & & & & & & \\
\hline BeG90N06B05 & Q96VN & Chitin deacetylase & $\uparrow$ & 1.4 & & 0.1 & & & & & & & & & \\
\hline
\end{tabular}




\begin{tabular}{|c|c|c|c|c|c|c|c|c|c|c|c|c|c|c|c|}
\hline BeZSPN18C06 & & proteophosphoglycan & $\uparrow$ & 1.2 & 1.3 & 1.0 & 3 & & & & & & & & \\
\hline BeE60N03F03 & & glucosamine--fructose-6-phosphate aminotransferase & $\uparrow$ & 1.8 & 1.2 & 0.8 & 5 & 1.0 & 1.1 & 1.1 & 1.2 & 1.5 & 2.1 & 1.0 & 6 \\
\hline BeZSPN18H03 & Q9SQF7 & Chitinase & $\uparrow$ & 1.4 & 1.3 & 1.1 & 3 & 1.0 & 1.2 & 1.1 & 1.2 & 1.3 & 1.5 & 1.2 & 6 \\
\hline \multicolumn{16}{|c|}{ Estrutura de Cromatina } \\
\hline BeG30N17G05 & Q1469 & programmed cell death 11 & $\downarrow$ & 0.9 & 0.7 & 0.9 & 4 & & & & & & & & \\
\hline BeE120N03F12 & Q9JM53 & Programmed cell death protein 8 , mitochondr & $\downarrow$ & & & & & 1.0 & 0.9 & 0.8 & 0.8 & 0.7 & 0.7 & 0.8 & 2 \\
\hline BeE30N02C10 & Q9HDN1 & Histone H3 & $\downarrow$ & & & & & 1.0 & 1.0 & 1.0 & 0.9 & 0.8 & 0.7 & 1.0 & 2 \\
\hline BeE60H06B09 & Q07135 & Histone $\mathrm{H} 2 \mathrm{~A}$ & $\downarrow$ & & & & & 1.0 & 1.0 & 1.1 & 0.9 & 0.8 & 0.6 & 1.1 & 2 \\
\hline BeNSVP07G09 & Q8J1K2 & Histone $\mathrm{H} 2 \mathrm{~B}$ & $\downarrow$ & & & & & 0.8 & 1.0 & 1.0 & 0.9 & 0.7 & 0.5 & 1.1 & 2 \\
\hline \multicolumn{16}{|c|}{ Reparo de DNA } \\
\hline BeE30N07D04 & 013768 & Putative dna repair helicase & $\uparrow$ & 2.0 & 1.6 & 1.0 & 5 & & & & & & & & \\
\hline \multicolumn{16}{|c|}{ Replicação de DNA } \\
\hline BeE60H16G11 & & Origin recognition complex, subunit 5 (ISS) & $\uparrow$ & 4.3 & 3.0 & 0.5 & 6 & 0.9 & 0.9 & 0.9 & 1.0 & 3.9 & 12.6 & 0.8 & 3 \\
\hline BeG120N03B10 & Q8R323 & Replication factor $\mathrm{C}$ subunit 3 & $\uparrow$ & 3.5 & 2.0 & 1.0 & 6 & & & & 1.1 & 2.2 & 6.5 & & 3 \\
\hline \multicolumn{16}{|c|}{ Metabolismo Energético } \\
\hline BeE90N17C02-1 & Q83PF & deoxyribose-phosphate aldolase [Escherichia coli] & $\downarrow$ & 0.6 & & 0.7 & & & & & & & & & \\
\hline BeG120N19C09 & & 6-phosphogluconolactonase [Laccaria bicolor & $\downarrow$ & 0.5 & & 0.9 & & & & & & & & & \\
\hline BeNSVP12G02 & & phosphoenolpyruvate carboxykinase [Emericella nidu & $\downarrow$ & 0.7 & 0.9 & 1.0 & 1 & & & & & & & & \\
\hline BeZSPN09E08 & Q7Z8B6 & $\mathrm{H}(+)$-ATPase [Glomus mosseae] & $\downarrow$ & 1.0 & 0.6 & 0.6 & 4 & & & & & & & & \\
\hline BeE120N27B02 & P5625 & Cytochrome c & $\downarrow$ & 0.6 & 0.7 & 1.0 & 1 & 1.0 & 0.9 & 0.9 & 0.9 & 0.5 & 0.3 & 1.4 & 1 \\
\hline BeE30N04B04 & Q9UVH9 & Fox2 protein & $\downarrow$ & 0.4 & 0.6 & 1.8 & 1 & 1.0 & 0.9 & 1.1 & 1.4 & 0.6 & 0.6 & 2.2 & 2 \\
\hline BeE60H29B11 & & ATP synthase epsilon chain domain containing protein & $\downarrow$ & 0.7 & 0.8 & 1.2 & 1 & 0.9 & 1.0 & 1.0 & 0.9 & 0.7 & 0.6 & 0.8 & 2 \\
\hline BeG30N08D01 & Q9Y3D8 & Adenylate kinase isoenzyme 6 & $\downarrow$ & 0.9 & 0.6 & 0.9 & 4 & 1.0 & 1.0 & 1.0 & 0.9 & 0.6 & 0.6 & 1.1 & 2 \\
\hline BeE120N27B03 & Q03015 & $\mathrm{NADH}$-ubiquinone oxidoreductase $12 \mathrm{kDa}$ subunit & $\downarrow$ & & & & & 1.1 & 0.8 & 0.9 & 0.9 & 0.8 & 0.7 & 1.0 & 2 \\
\hline BeE30N04H06 & Q9Z2K9 & Isocitrate dehydrogenase [NADP] cytoplasmic & $\downarrow$ & & & & & 1.1 & 1.3 & 1.2 & 1.1 & 0.6 & 0.8 & 1.0 & 2 \\
\hline BeE30N05E04 & Q7Z940 & Succinyl-CoA synthetase, beta subunit & $\downarrow$ & & & & & 1.1 & 1.1 & 0.9 & 0.8 & 0.7 & 0.7 & 1.0 & 2 \\
\hline BeE60N08H02 & 013350 & ATP synthase D chain, mitochondrial & $\downarrow$ & & & & & 1.0 & 1.1 & 1.0 & 1.0 & 0.7 & 0.8 & 0.9 & 2 \\
\hline BeG120N03B06 & Q9UWE0 & Dihydrolipoamide succinyltransferase & $\downarrow$ & & & & & 1.0 & 0.9 & 0.8 & 0.7 & 0.4 & 0.5 & 0.7 & 1 \\
\hline BeG120N07H08 & 074699 & Aconitase & $\downarrow$ & & & & & 1.0 & 0.9 & 0.8 & 0.9 & 1.0 & 0.8 & 1.4 & 2 \\
\hline BeG90N01G09 & Q7NJZ3 & Ribose 5-phosphate epimerase & $\downarrow$ & & & & & 0.8 & 0.7 & 0.8 & 0.8 & 0.6 & 0.4 & 0.8 & 2 \\
\hline BeG90N12C05 & & glutaryl-Coenzyme A dehydrogenase isoform a & $\downarrow$ & & & & & 1.0 & 1.0 & 0.9 & 0.7 & 0.6 & 0.4 & 0.9 & 2 \\
\hline $\mathrm{BeE60H08E04}$ & Q9A212 & Quinone oxidoreductase & $\uparrow$ & 1.2 & 1.5 & 1.0 & 3 & & & & & & & & \\
\hline BeE60H17D05 & P53659 & Vacuolar ATP synthase subunit d & $\uparrow$ & 1.5 & 1.4 & 1.0 & 3 & & & & & & & & \\
\hline BeE60H32F11 & & aldose 1-epimerase, putative [Aspergillus clavatus & $\uparrow$ & 1.7 & 1.2 & 0.9 & 5 & & & & & & & & \\
\hline BeE60N02F01 & & UTP-glucose-1-phosphate uridylyltransferase & $\uparrow$ & 1.5 & 1.9 & 1.0 & 3 & & & & & & & & \\
\hline BeE60N17G05 & Q9YHT2 & succinate dehydrogenase complex, subunit B & $\uparrow$ & 2.1 & 1.6 & 0.9 & 5 & & & & & & & & \\
\hline BeE90N05B09 & Q8GUB3 & Putative vacuolar ATPase subunit $\mathrm{H}$ & $\uparrow$ & 1.6 & 1.4 & 1.2 & 3 & & & & & & & & \\
\hline BeG30N12E07 & Q9P8D2 & Cytochrome c oxidase subunit V & $\uparrow$ & 1.4 & 1.2 & 0.9 & 5 & & & & & & & & \\
\hline BeG60N14B08 & Q86AV6 & citrate synthase [Dictyostelium discoideum & $\uparrow$ & & 1.7 & 1.1 & & & & & & & & & \\
\hline BeG90N01D12 & P4157 & 6-phosphogluconate dehydrogenase & $\uparrow$ & 1.0 & 2.2 & 1.1 & 3 & & & & & & & & \\
\hline BeG90N05E08 & Q9171 & Pyruvate dehydrogenase E1 component beta su & $\uparrow$ & 1.2 & 1.4 & 1.0 & 3 & & & & & & & & \\
\hline BeE120N03E01 & Q8ZN3 & D-lactate dehydrogenase & $\uparrow$ & 5.0 & 4.0 & 0.6 & 6 & 1.0 & 1.0 & 0.5 & 1.2 & 4.8 & 4.2 & 0.4 & 3 \\
\hline BeE30N02H06 & Q9P4V2 & Phosphoacetylglucosamine mutase & $\uparrow$ & 2.3 & 1.6 & 0.9 & 5 & & 1.1 & 0.9 & 1.3 & 2.0 & 2.2 & 0.9 & 6 \\
\hline BeE30N15D01 & & NADP-dependent alcohol dehydrogenase & $\uparrow$ & 1.6 & 2.9 & 1.4 & 3 & 1.0 & 1.0 & 1.3 & 1.3 & 2.5 & 3.7 & 1.2 & 7 \\
\hline BeE30N21H07 & P6738 & Glycogen phosphorylase & $\uparrow$ & 1.3 & 2.0 & 1.0 & 3 & 1.1 & 1.1 & 0.9 & 1.2 & 1.4 & 1.7 & 0.7 & 6 \\
\hline BeE60H08B07 & 074478 & phosphoglucomutase & $\uparrow$ & 1.5 & 1.4 & 1.0 & 3 & 1.0 & 1.3 & 0.9 & 1.1 & 1.2 & 1.6 & 1.1 & 6 \\
\hline BeE60N02G08 & & aldose 1-epimerase, putative & $\uparrow$ & 3.1 & 1.8 & 0.8 & 6 & 1.1 & 1.2 & 1.2 & 1.3 & 2.4 & 2.4 & 0.7 & 6 \\
\hline BeE60N05D05 & $\mathrm{Q} 8 \mathrm{EBH} 2$ & Transaldolase & $\uparrow$ & 1.5 & 1.5 & 1.0 & 3 & 1.1 & 1.0 & 1.0 & 1.2 & 1.6 & 3.1 & 0.8 & 6 \\
\hline BeE60N10B03 & & vacuolar ATP synthase subunit c" & $\uparrow$ & 2.1 & 1.3 & 0.9 & 5 & 0.9 & 1.2 & 1.1 & 1.4 & 2.3 & 2.2 & 0.8 & 6 \\
\hline BeE90N15E12 & & glycogen phosphorylase & $\uparrow$ & 1.5 & & 1.2 & & 1.1 & 1.0 & 0.9 & 1.2 & 1.7 & 2.1 & 0.8 & 6 \\
\hline BeG120N01F06 & 057656 & Glycerol-3-phosphate dehydrogenase [NAD+] & $\uparrow$ & 1.2 & 1.5 & 0.9 & 3 & 1.1 & 1.1 & 1.0 & 0.9 & 1.2 & 1.7 & 0.8 & 6 \\
\hline BeG30N15D05 & Q8Y2Q8 & carbonic anhydrase protein & $\uparrow$ & 5.5 & 2.8 & 0.5 & 6 & & 1.8 & 1.1 & 3.9 & 5.4 & 3.4 & 0.3 & 7 \\
\hline BeG90N11A02 & Q9WD9 & Glyceraldehyde 3-phosphate dehydrogenase & $\uparrow$ & 1.9 & 2.4 & 1.2 & 3 & 1.0 & 1.4 & 1.3 & 2.0 & 2.3 & 2.6 & 0.9 & 7 \\
\hline BeG90N18E08 & Q8X97 & Probable ATP-citrate synthase subunit 1 & $\uparrow$ & 1.7 & 1.1 & 0.4 & 5 & 1.0 & 1.3 & 1.1 & 1.2 & 1.3 & 2.0 & 0.4 & 6 \\
\hline BeE120N26G05 & P31413 & Vacuolar ATP synthase 16 kDa proteolipid subunit & $\uparrow$ & & & & & 1.0 & 1.1 & 1.1 & 1.3 & 1.5 & 1.4 & 1.0 & 6 \\
\hline BeG120N06H01 & & similar to phosphoglucomutase 2 & $\uparrow$ & & & & & 1.0 & 1.3 & 0.9 & 1.1 & 1.3 & 1.6 & 1.1 & 6 \\
\hline BeG90N03E03 & P42894 & Enolase & $\uparrow$ & & & & & 1.0 & 1.2 & 1.1 & 1.4 & 1.6 & 1.9 & 0.7 & 6 \\
\hline BeG90N13C04 & & phosphoglucose isomerase & $\uparrow$ & & & & & & 1.1 & 1.2 & & 1.3 & 1.3 & & 6 \\
\hline
\end{tabular}


BeE60N04H10 BeE60C10H10 BeE60N09D01

\section{BeE60C35H0}

BeG90N21B12

BeE30N02B11

BeE60C25C06

BeE60N03A03

BeG90N07B07

BeE120N30F01

BeE60H26A05

BeG120N16E05

BeG60N06G05

BeE60C08F07

BeE60N03G10

BeZSPN13B04

BeE30N04A05

BeE90D17G07

BeG90N16H08

BeZSPN02F03

BeE30N17G08

BeE30N18D07

BeG60N16H02

BeG9ONO9B12

BeG90N12C08

BeG30N12D07

BeG3ON15B12

BeG3ON20G08

BeG60N19B01

BeE60C24G08

BeG120N09C02

BeG9ON18B04

BeG60N01B06

BeZSPNO3F10

BeE30N01E09

BeE30N07A05

BeE90D15C05

BeG90N19E11

BeNSVP04F11

BeE120N25C08

BeE60C10B01

BeE90D18C05

BeG9ON06E08

BeG3ON09D02

BeG60N02F10

BeG30N13A10

BeG90N15D01

BeE120N06H09

BeE120N20H04

BeE30N09G01

BeE30N16B09

BeE3ON22H03

BeE60H10E07

BeE6OH22A09
Q9Y6M9 NADH-ubiquinone oxidoreductase B22 subunit

Mandelate racemase/muconate lactonizing enzyme-like acyl-coenzyme A oxidase I, putative

\section{Metabolismo de Lipídeos}

Q8BH95 Enoyl coenzyme A hydratase

Enoyl-CoA hydratase (31.2 kD) [Caenorhabditis eleg

fatty acid-2 hydroxylase [Laccaria bicolor

Q88LT3 1-acyl-sn-glycerol-3-phosphate acyltransferase

C-5 sterol desaturase

leukotriene A4 hydrolase

P5345 C-4 methyl sterol oxidase

Q872A4 Related to phosphatidylserine decarboxylase

P4398 Fatty acid synthase subunit alpha

P7978 Delta-9 fatty acid desaturase

Deoxyhypusine hydroxylase (Deoxyhypusine monooxygenase)

cyclopropane-fatty-acyl-phospholipid synthase

1-acylglycerol-3-phosphate acyltransferase (AtaAp)

delta 4-(E)-sphingolipid desaturase

Q9P4D7 Long chain polyunsaturated fatty acid elongation enzyme

Q7ZA40 Serine palmitoyl transferase subunit

P33121

Long-chain-fatty-acid--CoA ligase 2

\section{Metabolismo de Ácidos Nucleicos}

Q7ZV49 hypoxanthine phosphoribosyltransferase I

ATP phosphoribosyltransferase

Q9BLT3 Nucleoside hydrolase

Q27124 ribonuleotide reductase small subunit

similar to Endonuclease G like 1 (Endo G like)

093937 PyrABCN

URA1 protein

Q8NIH8 Nuclease Le3

P38625 GMP synthase [glutamine-hydrolyzing]

Q8XRK0 TDP-glucose-4,6-dehydratase-related protein

Q8NIH8

Nuclease Le3

Adsl-prov protein

Q84P58 Adenosine kinase-like protein

probable inosine-5\'-monophosphate dehydrogenase

putative purine nucleoside phosphorylase

Nucleoside phosphorylase

094413 Ribose-phosphate pyrophosphokinase

Q871N5 Probable uracil phosphoribosyltransferase F

similar to cytidine deaminase

P20054 Protein PYR1-3

Q8D6V0 Predicted nucleotidyltransferase

O42806 Cpa protein (Fragment)

Q2787 Adenylosuccinate synthetase

5\'-3\' exoribonuclease 2; Dhm1-like protein

Q9VC99 Probable uridine-cytidine kinase

Q9KVD5 Orotate phosphoribosyltransferase

P21588 5'-nucleotidase precursor

\section{Enovelamento e Modificação de Proteínas}

$013351 \quad$ Ubiquitin-like protein smt3/pmt3

Q9M4C4

putative protein serine/threonine kinase

077622 T-complex protein 1, zeta subunit

Q9UTS Hypothetical subtilase-type proteinase psp3

T-complex protein 1, theta subunit

Q13526

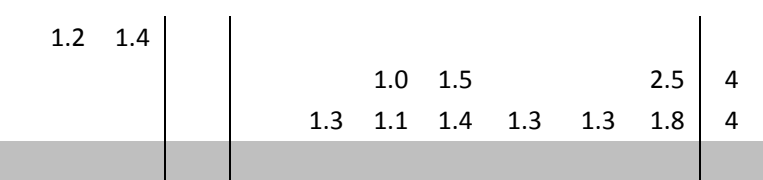

$\downarrow$

$\downarrow$

\begin{tabular}{llll|l}
$\uparrow$ & 2.2 & 1.1 & 0.9 & 5
\end{tabular}

$\uparrow \quad 1.1 \quad 0.3$

$\uparrow \quad 1.7$

\begin{tabular}{l|lll|l}
$\uparrow$ & 1.6 & 1.1 & 0.7 & 5
\end{tabular}

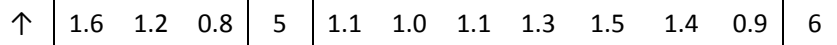

\begin{tabular}{|l|lll|l|llllllll|l}
$\uparrow$ & 5.0 & 2.6 & 1.0 & 6 & 0.9 & 1.8 & 2.5 & 6.1 & 15.8 & 12.6 & 2.7 & 7
\end{tabular}

\begin{tabular}{llll|l|lllllllll}
$\uparrow$ & 1.5 & 1.7 & 0.4 & 5 & 1.0 & 1.3 & 1.1 & 1.1 & 1.8 & 2.0 & 0.5 & 6
\end{tabular}

\begin{tabular}{llll|l|lllllll|l|}
$\uparrow$ & 3.1 & 1.9 & 0.3 & 6 & 1.0 & 1.9 & 0.7 & 1.4 & 3.8 & 4.4 & 0.2 & 3
\end{tabular}

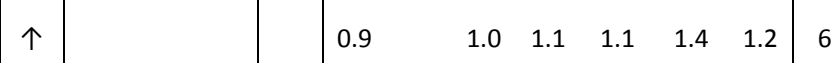

\begin{tabular}{l|lllllllll}
$\uparrow$ & 1.1 & 1.8 & 1.5 & 3.8 & 8.9 & 5.7 & 2.0 & 7 \\
1
\end{tabular}

\begin{tabular}{l|lllllll|l}
$\uparrow$ & 0.9 & 0.8 & 1.1 & 1.0 & 1.2 & 1.5 & 0.9 & 6
\end{tabular}

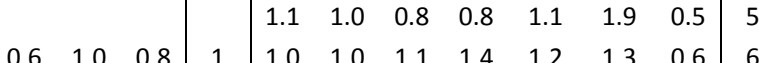

\begin{tabular}{lll|l|llllllll}
0.6 & 1.0 & 0.8 & 1 & 1.0 & 1.0 & 1.1 & 1.4 & 1.2 & 1.3 & 0.6 & 6 \\
& & & & 0.9 & 1.3 & 1.2 & 1.4 & 1.2 & 1.5 & 1.2 & 4
\end{tabular}

$\begin{array}{llllllllll}0.9 & 1.0 & 1.0 & 1.0 & 0.7 & 0.9 & 0.9 & 5\end{array}$

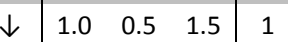

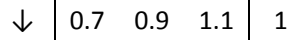

$\downarrow$

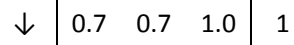

$\downarrow$

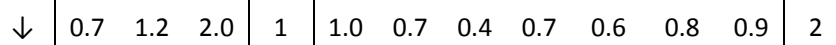

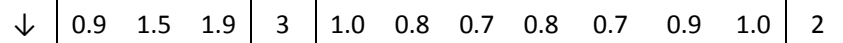

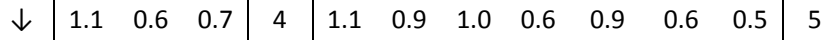

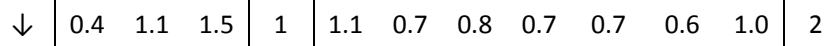

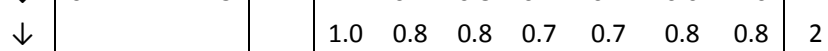

\begin{tabular}{llllllll|l}
1.2 & 1.3 & 1.0 & 0.9 & 0.6 & 0.7 & 1.0 & 2
\end{tabular}

\begin{tabular}{lllllll|l}
1.0 & 0.7 & & 0.5 & & 0.6 & 0.8 & 2 \\
1.0 & 0.8 & 0.6 & 0.7 & 0.4 & 0.5 & 0.7 & 2
\end{tabular}

$\downarrow$

$\uparrow$\begin{tabular}{lll|l}
1.1 & 1.5 & 1.4 & 3
\end{tabular}

\begin{tabular}{llll|l|lllllll|l}
$\uparrow$ & 3.7 & 1.4 & 0.6 & 6 & 1.1 & 1.1 & 0.7 & 1.0 & 2.0 & 4.7 & 0.6 & 3
\end{tabular}

\begin{tabular}{llll|l|llllllll|l}
$\uparrow$ & 4.7 & 2.3 & 0.7 & 6 & 1.1 & 1.2 & 0.7 & 1.1 & 4.3 & 4.6 & 0.6 & 3 \\
\hline
\end{tabular}

\begin{tabular}{llll|l|lllllll|l}
$\uparrow$ & 1.9 & 1.7 & 1.3 & 3 & 1.1 & 0.9 & 0.9 & 0.9 & 1.4 & 1.7 & 0.9 & 6
\end{tabular}

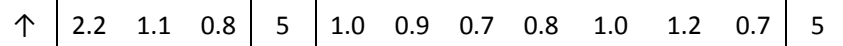

\begin{tabular}{llll|l|lllllll|l}
$\uparrow$ & 2.3 & 0.7 & 0.4 & 5 & 0.9 & 1.2 & 1.3 & 2.6 & 1.0 & 6
\end{tabular}

\begin{tabular}{lll|l|llllllll|l}
$\uparrow$ & & & & & & 0.9 & 1.2 & & 1.3 & 2.6 & & 1.0 \\
1.1 & 1.1 & 1.1 & 1.0 & 2.2 & 1.3 & 0.7 & 6
\end{tabular}

\begin{tabular}{llllll|l}
1.1 & 0.9 & 1.4 & 2.3 & 1.5 & 1.3 & 6
\end{tabular}

$\uparrow$

\begin{tabular}{lll|l}
1.0 & 1.2 & 1.5 & 3
\end{tabular}

\begin{tabular}{lllllll|l}
1.0 & 1.0 & 0.9 & 0.9 & 2.2 & 1.5 & 0.5 & 6
\end{tabular}

1.0

0.8

0.5

$0.6 \quad 5$

\begin{tabular}{lllllll|l}
1.1 & 0.8 & 0.8 & 0.7 & 0.7 & 0.8 & 0.7 & 5
\end{tabular} 


\begin{tabular}{|c|c|c|c|c|c|c|c|c|c|c|c|c|c|c|c|}
\hline BeE60H30E02 & 06953 & 20S proteasome subunit & $\downarrow$ & 0.5 & 0.9 & 0.7 & 1 & & & & & & & & \\
\hline BeE60H32E04 & 042993 & Peptidyl-prolyl cis-trans isomerase & $\downarrow$ & 0.6 & 0.7 & 0.8 & 1 & & & & & & & & \\
\hline BeE60N11B08 & Q9M77 & Putative serine/threonine protein kinase & $\downarrow$ & 0.6 & 0.7 & 0.9 & 1 & & & & & & & & \\
\hline BeE90D20D04 & P5999 & T-complex protein 1 , delta subunit & $\downarrow$ & 0.7 & 0.9 & 0.9 & 1 & & & & & & & & \\
\hline BeE60C24C07 & Q7ZA53 & Peptidyl-prolyl cis-trans isomerase & $\downarrow$ & 0.6 & 0.7 & 0.9 & 1 & 0.9 & 1.0 & 1.0 & 1.2 & 0.9 & 0.7 & 0.9 & 2 \\
\hline BeE60N07C06 & Q9UTM4 & T-complex protein 1 , epsilon subunit & $\downarrow$ & 0.5 & & & & 1.0 & 1.1 & 1.0 & 1.1 & 0.6 & 0.6 & 0.9 & 2 \\
\hline BeE60N07G09 & Q872U9 & Probable chaperonin of the TCP1 ring comple & $\downarrow$ & 0.7 & 0.8 & 0.8 & 1 & 1.0 & 0.9 & 0.9 & 1.0 & 0.6 & 0.7 & 0.7 & 2 \\
\hline BeG120N23B05 & Q99832 & T-complex protein 1 , eta subunit & $\downarrow$ & 0.6 & 0.8 & 0.9 & 1 & 1.0 & 1.0 & 0.9 & 0.9 & 0.7 & 0.7 & 0.8 & 2 \\
\hline BeE60H30F05 & & similar to Chaperonin containing TCP1, subunit 4 (delta) & $\downarrow$ & & & & & 1.0 & 0.9 & 0.9 & 0.8 & 0.7 & 0.7 & 0.8 & 2 \\
\hline BeE60N15H02 & P24155 & Thimet oligopeptidase & $\downarrow$ & & & & & 1.1 & 0.9 & 1.0 & 0.8 & 0.7 & 0.6 & 0.9 & 2 \\
\hline BeG120N17H03 & P46595 & Ubiquitin-conjugating enzyme E2 4 & $\downarrow$ & & & & & 1.0 & 1.1 & 1.1 & 1.1 & 0.9 & 0.7 & 0.8 & 2 \\
\hline BeG90N16A03 & Q9VSF3 & NEDD8 conjugating enzyme Ubc12 & $\downarrow$ & & & & & 0.9 & 1.0 & 1.0 & 1.1 & 0.9 & 0.6 & 0.9 & 2 \\
\hline BeG90N22B10 & Q7Q8R2 & AgCP11849 (Fragment) & $\downarrow$ & & & & & 1.0 & 0.9 & 0.9 & 0.8 & 0.8 & 0.6 & 1.1 & 2 \\
\hline BeE60N18G04 & 06178 & protein $\mathrm{N}$-terminal asparagine amidohydrolase & $\uparrow$ & 1.7 & 1.4 & 1.2 & 3 & & & & & & & & \\
\hline BeE90D03E05 & Q9NTU3 & Ubiquitin-activating enzyme 3 & $\uparrow$ & 1.6 & 1.5 & 1.0 & 3 & & & & & & & & \\
\hline BeG60N12E03 & 043447 & Peptidyl-prolyl cis-trans isomerase $\mathrm{H}$ & $\uparrow$ & 1.5 & 1.1 & 0.9 & 5 & & & & & & & & \\
\hline BeE90D05G05 & Q7Z8F2 & Putative serine/threonine phosphatase $2 \mathrm{C}$ ptc2 & $\uparrow$ & 2.3 & 1.9 & 0.9 & 5 & 1.0 & 1.3 & 1.5 & 2.2 & 4.9 & 4.8 & 0.9 & 7 \\
\hline BeG120N03B03 & & CasA & $\uparrow$ & 2.2 & 1.2 & 0.8 & 5 & 1.0 & 1.2 & 1.1 & 1.4 & 2.3 & 3.7 & 0.9 & 7 \\
\hline BeE60H17C06 & P52495 & Ubiquitin-activating enzyme E1 1 (Fragment) & $\uparrow$ & & & & & 1.0 & 1.1 & 1.1 & 1.4 & 1.1 & 1.1 & 0.7 & 6 \\
\hline BeE6OH22F09 & 074819 & POLYUBIQUITIN & $\uparrow$ & & & & & 0.9 & 1.2 & 1.2 & 1.4 & 1.3 & 1.5 & 1.2 & 6 \\
\hline & & Homeostase Redox & & & & & & & & & & & & & \\
\hline BeE60C19G01 & Q4IHX8 & Thioredoxin peroxidase & $\downarrow$ & 0.6 & 1.1 & 1.0 & 1 & & & & & & & & \\
\hline BeE60H29E07 & Q1137 & Superoxide dismutase [Cu-Zn] & $\downarrow$ & 0.6 & 0.8 & 0.9 & 1 & & & & & & & & \\
\hline BeE90N13F05 & Q9NL96 & Glutathione reductase & $\downarrow$ & 0.2 & 1.3 & 0.9 & 2 & & & & & & & & \\
\hline BeE60N14F11 & Q9BGI3 & Peroxiredoxin 2 & $\uparrow$ & & & & & 0.7 & 1.1 & 1.2 & 1.3 & 1.3 & 1.3 & 1.1 & 6 \\
\hline BeE90D18F01 & P40581 & Glutathione peroxidase 3 & $\uparrow$ & & & & & 0.9 & 1.1 & 1.3 & 1.4 & 1.2 & 1.5 & 1.2 & 6 \\
\hline & & Proteínas Ribossômicas / Tradução & & & & & & & & & & & & & \\
\hline BeE120N37D12 & P38665 & $60 \mathrm{~S}$ ribosomal protein $\mathrm{L} 24$ & $\downarrow$ & 1.0 & 0.6 & 1.0 & 4 & & & & & & & & 6 \\
\hline $\mathrm{BeE60H23E04}$ & 042952 & $40 \mathrm{~S}$ ribosomal protein & $\downarrow$ & 0.6 & 0.7 & 1.0 & 1 & & & & & & & & \\
\hline BeE60N19C01 & 074966 & Probable small nuclear ribonucleoprotein $\mathrm{G}$ & $\downarrow$ & 0.9 & 0.6 & 1.0 & 4 & & & & & & & & \\
\hline BeE90D08E09 & Q9XGL4 & $60 S$ ribosomal protein $\mathrm{L} 31$ & $\downarrow$ & 0.7 & 1.0 & 0.9 & 1 & & & & & & & & \\
\hline BeG120N01H09 & & structural constituent of ribosome [C. neoformans & $\downarrow$ & 0.6 & 0.8 & 1.0 & 1 & & & & & & & & \\
\hline $\mathrm{BeG} 12 \mathrm{ON} 10 \mathrm{H} 02$ & Q95V37 & ribosomal protein L29 [Bombyx mori] & $\downarrow$ & 0.6 & 0.9 & & & & & & & & & & \\
\hline BeG90N04A04 & & Probable eukaryotic translation initiation factor & $\downarrow$ & 0.6 & 0.7 & 1.1 & 1 & & & & & & & & \\
\hline BeG90N09C08 & & Elongation factor $\mathrm{G} 1$, mitochondrial precursor ( $\mathrm{mE}$ & $\downarrow$ & & 0.3 & 1.3 & & & & & & & & & \\
\hline BeG90N15C05 & Q9S826 & Putative U3 small nucleolar ribonucleoprotein & $\downarrow$ & 1.0 & 0.7 & 1.0 & 4 & & & & & & & & \\
\hline BeE30N15A04 & P7983 & Eukaryotic translation initiation factor 3 & $\downarrow$ & 0.7 & 0.7 & 1.0 & 1 & 1.0 & 0.9 & 0.8 & 0.8 & 0.5 & 0.6 & 1.0 & \\
\hline BeG120N20E02 & Q9NPE3 & H/ACA ribonucleoprotein complex subunit 3 & $\downarrow$ & 0.4 & 0.4 & 0.9 & 2 & 0.9 & 0.9 & 1.1 & 0.9 & 0.3 & 0.3 & 1.3 & 2 \\
\hline BeG60N15D01 & 07469 & SNU13 snRNP subunit homolog & $\downarrow$ & 0.6 & 0.5 & 0.9 & 1 & 1.0 & 0.9 & 0.9 & 0.8 & 0.4 & 0.2 & 1.2 & 1 \\
\hline BeG90N02G11 & & phenylalanine-tRNA ligase & $\downarrow$ & 0.9 & & 0.5 & & & 0.9 & 1.0 & 0.9 & 0.4 & 0.9 & 1.0 & 1 \\
\hline BeG90N10A10 & P32495 & High mobility group & $\downarrow$ & & 0.5 & 0.9 & & 1.0 & 1.0 & 0.9 & 0.9 & 0.5 & 0.4 & 1.2 & 2 \\
\hline BeG120N22D07 & Q556 & Arginyl tRNA synthetase, cytoplasmic & $\downarrow$ & 0.7 & 0.6 & 1.2 & 1 & 1.0 & 1.1 & 1.3 & 1.0 & 0.5 & 0.5 & 1.7 & 1 \\
\hline BeNSVP10C04 & & elF3/signalosome protein & $\downarrow$ & 0.6 & & & & 0.9 & 0.9 & 1.0 & 0.7 & 0.5 & 0.5 & 1.3 & 1 \\
\hline BeE30N13H12 & & lysyl-tRNA synthetase & $\downarrow$ & & & & & 1.0 & 1.0 & 0.9 & 0.8 & 0.6 & 0.6 & 1.0 & 2 \\
\hline BeE30N18E04 & & glycyl-tRNA synthetase & $\downarrow$ & & & & & 1.0 & 0.9 & 0.8 & 0.8 & 0.7 & 0.8 & 0.9 & 2 \\
\hline BeE3ON22E01 & 014339 & $60 \mathrm{~S}$ ribosomal protein L17-A & $\downarrow$ & & & & & 0.9 & 0.9 & 0.8 & 0.8 & 0.7 & 0.7 & 0.8 & 2 \\
\hline
\end{tabular}


BeE60H15C05

BeG120N04E02

BeG120N11F05

BeG120N13E04

BeG30N06D06

BeG30N13C06

BeZSPN06C04

BeZSPN17H02

BeE60N04D02

BeG3ON13H07

BeG90N19F12

BeG90N07C02

BeNSVP07H09

\section{BeZSPN08B03}

BeG120N08G05 Q9P72

BeG120N26G03

BeG30N02C06

BeG9ON08H03

BeG30N14A04

BeE120N02E04 O

BeE120N02E04

BeE60N16D02

BeG90N08A02

BeZSPN16D09

BeE120N28E07

\begin{tabular}{|c|c|c|}
\hline BeE120N28E07 & Q9HFN1 & G protein alpha subunit (Fragment) \\
\hline & & Resposta a Estresse \\
\hline BeZSPN11F03 & & $10 \mathrm{kDa}$ heat shock protein, mitochondrial \\
\hline BeG60N07C03 & Q9S9N1 & Hsp70-3 (Blastocladiella emersonii) \\
\hline BeE6OH2OC05 & P22774 & Hsp70-9 (Blastocladiella emersonii) \\
\hline BeE60H29E01 & & putative stress-related protein \\
\hline BeE60H06A02 & P4872 & Hsp70-1 (Blastocladiella emersonii) \\
\hline BeE60C13A12 & Q8DM43 & Heat shock protein \\
\hline
\end{tabular}

Homo sapiens eukaryotic translation initiation factor $1 \mathrm{~A}$

similar to Eukaryotic translation initiation factor

014044 Ribosomal RNA processing protein 28

Q09692 tryptophanyl-tRNA synthetase

similar to Fibrillarin CG9888PA

Q9CHN6 Elongation factor $P$

Q13685 ribosome biogenesis protein Sqt1

P29691 Elongation factor 2

Q84KQ4 Elongation factor-1alpha (Fragment)

Q84KQ4 Elongation factor-1alpha (Fragment)

$50 \mathrm{~S}$ ribosomal protein L2

$60 S$ ribosomal protein $\mathrm{L} 16$

elongation factor EF-Tu

tRNA synthetase

50 S ribosomal protein $\mathrm{L} 3$

eukaryotic translation initiation factor 3 subunit 7 Transdução de Sinal

Q7YXG1 soluble guanylyl cyclase 2 beta

P3446 Guanine nucleotide-binding protein alpha-8

Q9W711 activated protein kinase $C$ receptor

Q12741 cAMP-dependent protein kinase catalytic sub

$G$ protein alpha subunit (Fragment)
Threonyl-tRNA synthetase, cytoplasmic

Q9HGT6 Seryl-tRNA synthetase, cytoplasmic

IF5_YEAST Eukaryotic translation initiation factor 5

$\downarrow$
$\downarrow$
$\downarrow$
$\downarrow$
$\downarrow$
$\downarrow$
$\downarrow$
$\downarrow$
$\uparrow$
$\uparrow$
$\uparrow$
$\uparrow$
$\uparrow$

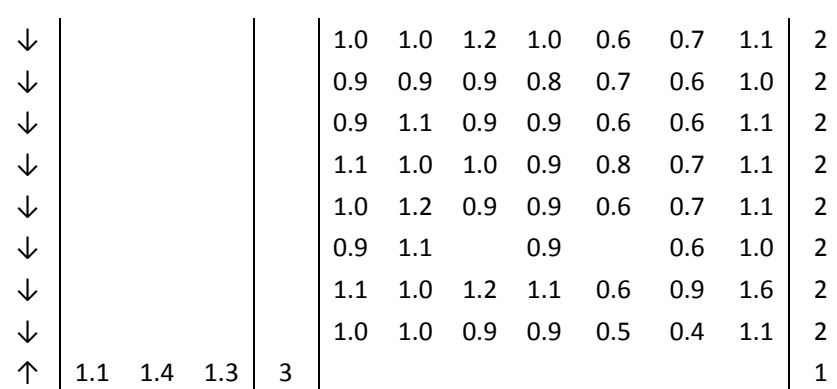

$\uparrow \begin{array}{lll}1.2 & 0.4\end{array}$

\begin{tabular}{lll|l}
1.2 & 1.6 & 0.5 & 5
\end{tabular}

$\uparrow$

\begin{tabular}{lll|l}
0.9 & 1.1 & 1.3 & 3
\end{tabular} 1.0 \begin{tabular}{lll|l}
1.0 & 0.4 & 0.4 & 4 \\
0.9 & 1.1 & 1.3 & 3
\end{tabular}

Estrutura Celular / Microtúbulos

BeE120N07A12

BeE60N12E01

BeE90N17C06

BeE60H23E05

BeG30N07C04

BeE60N03E07

BeE60N12G09

BeE60H28B01

BeE60N13F03

BeE9OD08H04

Q9196

roadblock-related dynein light chain

Q9SMH3 Dynein 1-alpha heavy chain

calponin/transgelin

P25323 Myosin light chain kinase

beta-tubulin

P7436 Tubulin beta-1 chain

P10989 Actin

beta-tubulin

Q9UFH2 Axonemal beta dynein heavy chain 17 Transcrição / Processamento de RNA

BeE90D17A08 Q7ZY47 ATP-dependent RNA helicase DDX42

BeZSPN12F04 Q3532

BeG120N02A10 Q9916

BeE3ON22H05 08198

BeE90D16F01 Q9P6Q6

BeG90N17F03 Q9NQT4

Probable ATP-dependent RNA helicase HAS1

Putative ATP dependent RNA helicase C1F7.02

RNA polymerase I, II and III $24.3 \mathrm{kDa}$ subun

mRNA-capping enzyme subunit beta

BeZSPN17G09

BeE30N15E05

BeG90N10B01

BeE60N18A09

BeG60N07D01

BeE90D08E03

BeG90N19A06

BeE60N11E05

Q8BU5

exosome component Rrp46 [Homo sapiens]

P2441

DNA-directed RNA polymerases III $12.5 \mathrm{kDa}$

Ras-related protein Rab-11A

DNA-directed RNA polymerase I subunit $D$ protein

Q9UVL1 Nonhistone protein 6

Q8MYR3 La related protein

RNA polymerase II elongator-associated protein putative reverse transcriptase-RNaseH-integrase

094666

DNA-directed RNA polymerase III largest sub

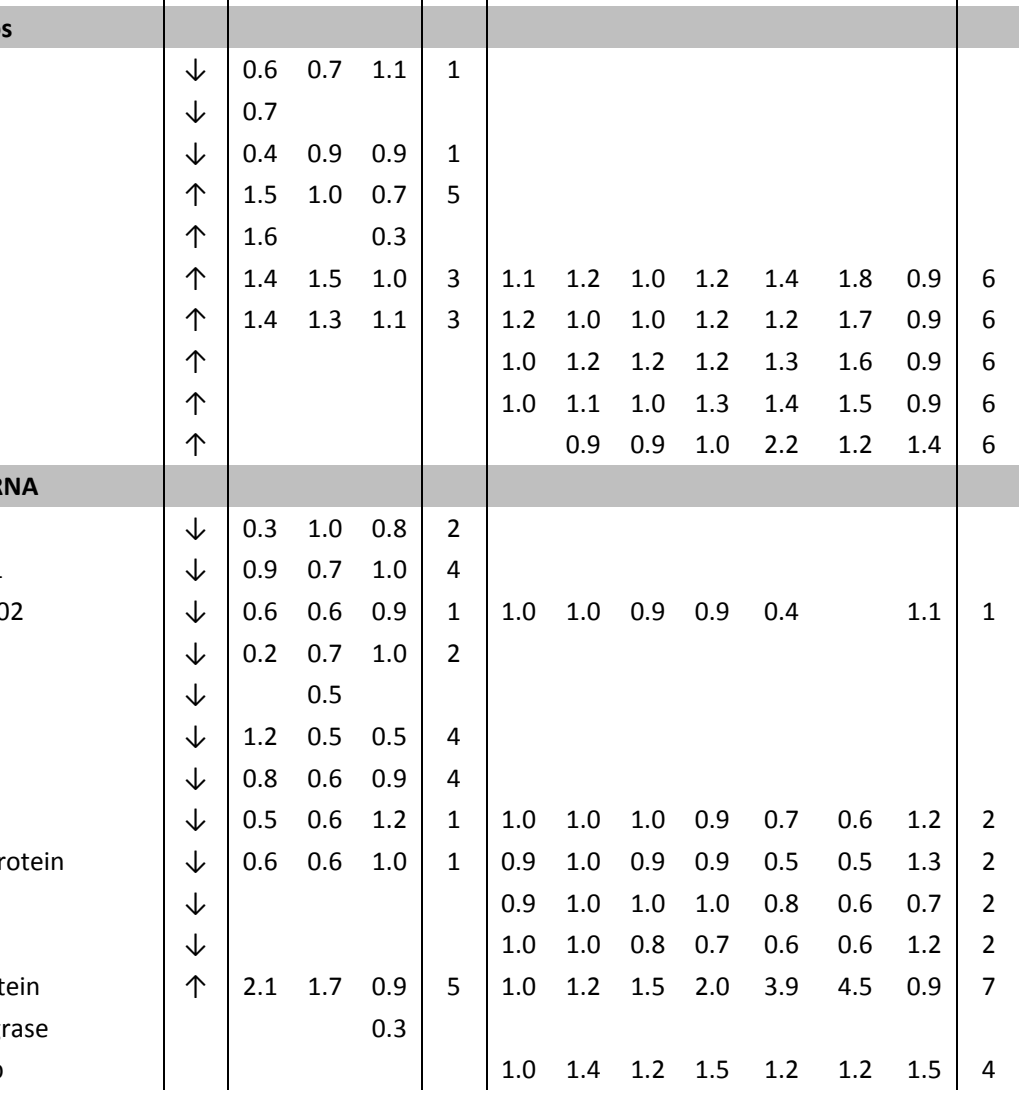


BeG60N15E01 Q00659 Sulfur metabolite repression control protein

\begin{tabular}{|c|c|c|c|c|c|c|c|c|c|c|c|c|c|c|c|}
\hline BeG60N15E01 & Q00659 & Sulfur metabolite repression control protein & & & & & & 1.0 & 1.2 & 1.0 & 1.2 & 1.1 & 1.1 & 1.4 & 4 \\
\hline \multicolumn{16}{|c|}{ Transporte } \\
\hline BeE120N01A01 & Q87C4 & Cationic amino acid transporter & $\downarrow$ & 0.5 & 0.8 & 0.8 & 1 & & & & & & & & \\
\hline BeE120N35H01 & Q7SAQ1 & Clathrin assembly protein 2 small chain & $\downarrow$ & 0.6 & 0.6 & 0.7 & 1 & & & & & & & & \\
\hline BeE60H21G09 & Q8RBT1 & Amino acid transporters & $\downarrow$ & 1.0 & 0.7 & 0.8 & 4 & & & & & & & & \\
\hline BeE90D19D08 & Q8T665 & $\mathrm{ABC}$ transporter $\mathrm{Abc \textrm {H }} .1$ & $\downarrow$ & 0.6 & 1.0 & 0.9 & 1 & & & & & & & & \\
\hline BeG120N07E03 & Q9P8H & nuclear transport factor 2 (ntf-2), putative & $\downarrow$ & 0.6 & 0.8 & 1.1 & 1 & & & & & & & & \\
\hline BeG90N14C01 & & high affinity methionine permease [Aspergillus clavatus & $\downarrow$ & & 0.2 & & & & & & & & & & \\
\hline BeE30N06H12 & & Peptide transporter PepT1 & $\downarrow$ & 0.7 & 0.7 & 1.0 & 1 & 1.0 & 0.9 & 0.9 & 0.8 & 0.6 & 0.7 & 0.9 & 2 \\
\hline BeE30N10D02 & Q6593 & Oligopeptide transporter 2 & $\downarrow$ & 0.4 & 0.1 & 1.0 & 8 & 1.1 & 1.0 & 1.2 & 1.1 & 0.5 & 0.5 & 0.7 & 1 \\
\hline BeE30N17A03 & P4897 & High affinity transporter for glutathione & $\downarrow$ & 0.3 & 0.5 & 0.8 & 2 & 1.0 & 1.0 & 1.1 & 1.1 & 0.4 & 0.4 & 0.8 & 1 \\
\hline BeE60N10A01 & P38264 & Inorganic phosphate transporter $\mathrm{PHO} 88$ & $\downarrow$ & 0.4 & 0.7 & 1.4 & 1 & 0.9 & 0.8 & 0.7 & 0.7 & 0.3 & 0.3 & 0.8 & 1 \\
\hline BeE60N13C09 & P7144 & Outer mitochondrial membrane protein porin & $\downarrow$ & 0.7 & 0.8 & 0.9 & 1 & 1.0 & 0.9 & 0.7 & 0.9 & 0.5 & 0.5 & 0.8 & 2 \\
\hline BeG60N20F09 & Q87216 & Probable iron inhibited $A B C$ transporter 2 & $\downarrow$ & 0.7 & 0.7 & 1.0 & 1 & 1.0 & 1.0 & 1.1 & 1.0 & 0.7 & 0.7 & 1.4 & 2 \\
\hline BeG90N09B05 & & proton-glutamate symporter & $\downarrow$ & 0.5 & & & & 1.1 & 0.9 & 0.8 & 0.5 & 0.4 & 0.4 & 0.7 & 2 \\
\hline BeE120N04F11 & & putative mitochondrial carrier protein & $\downarrow$ & & & & & 1.0 & 0.8 & 0.8 & 0.7 & 0.7 & 0.7 & 0.7 & 2 \\
\hline BeE60H30F10 & Q10481 & $\begin{array}{l}\text { Mitochondrial import inner membrane translocase } \\
\text { subunit tim13 }\end{array}$ & $\downarrow$ & & & & & 1.1 & 0.9 & 1.0 & 0.9 & 0.8 & 0.7 & 1.1 & 2 \\
\hline BeE60N18A11 & & putative phosphate/phosphoenolpyruvate translocator & $\downarrow$ & & & & & 1.0 & 1.0 & 0.9 & 1.0 & 0.8 & 0.6 & 0.8 & 2 \\
\hline BeG120N24A07 & Q8H727 & ADP/ATP translocase & $\downarrow$ & & & & & & 1.2 & 1.0 & 0.7 & 0.6 & 0.7 & 0.8 & 2 \\
\hline BeG30N12H02 & & probable amino acid transporter & $\downarrow$ & & & & & 1.0 & 1.1 & 1.1 & 1.2 & 0.8 & 0.7 & 1.0 & 2 \\
\hline BeG30N19C05 & Q63424 & Oligopeptide transporter, kidney isoform & $\downarrow$ & & & & & & 0.8 & 0.7 & 0.6 & 0.8 & 0.5 & 1.0 & 2 \\
\hline BeG90N09D08 & 074700 & $\begin{array}{l}\text { Mitochondrial import inner membrane translocase } \\
\text { subunit TIM9 }\end{array}$ & $\downarrow$ & & & & & 0.9 & 0.8 & 0.8 & 0.6 & 0.6 & 0.4 & 1.0 & 1 \\
\hline BeG90N16G06 & Q9UUY0 & calcium P-type ATPase & $\downarrow$ & & & & & 1.0 & 1.0 & 1.0 & 0.9 & 0.7 & 0.6 & 0.9 & 2 \\
\hline BeZSPN05F06 & & hypothetical protein [Neurospora crassa] & $\downarrow$ & & & & & 1.0 & 1.0 & 1.0 & 0.9 & 0.7 & 0.8 & 1.5 & 2 \\
\hline BeE90N13G10 & P21851 & dapter-related protein complex 2 beta 1 subunit & $\uparrow$ & 1.3 & 1.5 & 1.0 & 3 & & & & & & & & \\
\hline BeG120N07C03 & Q84VI6 & Phosphate transporter HvPT7 & $\uparrow$ & 1.2 & 1.3 & 1.3 & 3 & & & & & & & & \\
\hline BeG60N01F09 & & methionine permease, putative [Neosartorya fischeri & $\uparrow$ & 1.6 & 2.1 & 0.9 & 3 & & & & & & & & \\
\hline BeG90N07C10 & Q8TGD1 & tricarboxylate carrier, putative & $\uparrow$ & 1.2 & 2.2 & 0.6 & 5 & & & & & & & & \\
\hline $\mathrm{BeE} 60 \mathrm{H} 32 \mathrm{G} 06$ & P15847 & Trafficking protein particle complex subunit 5 & $\uparrow$ & 3.0 & 1.9 & 0.9 & 6 & 0.9 & 0.9 & 1.1 & 1.4 & 3.6 & 9.2 & 0.7 & 3 \\
\hline BeE60N12D06 & Q9JL62 & Glycolipid transfer protein & $\uparrow$ & 2.3 & 1.7 & 1.1 & 5 & 1.0 & 1.3 & 1.3 & 1.9 & 2.8 & 2.8 & 1.0 & 7 \\
\hline BeG120N22G10 & & MFS quinate transporter & $\uparrow$ & 1.4 & 1.0 & 0.6 & 5 & 1.0 & 1.0 & 1.1 & 1.2 & 1.7 & 1.0 & 0.9 & 6 \\
\hline BeG90N01D10 & Q8WZW8 & Probable YHM1 mitochondrial carrier protein & $\uparrow$ & 1.6 & 1.0 & 0.9 & 5 & 1.0 & 0.9 & 0.8 & 0.8 & 0.9 & 0.8 & 0.7 & 5 \\
\hline BeG90N16C06 & P42833 & Hexose transporter HXT14 & $\uparrow$ & 2.0 & 1.0 & 0.4 & 5 & 1.1 & 0.9 & 1.2 & 1.5 & 1.9 & 1.1 & 1.0 & 6 \\
\hline BeNSVP07B10 & & proton glutamate symport protein & $\uparrow$ & 0.9 & 1.6 & 1.0 & 3 & 0.8 & 0.8 & 1.0 & 1.2 & 1.4 & 1.8 & 1.0 & 6 \\
\hline BeZSPN02C07 & & hypothetical nicotinamide mononucleotide transporter & $\uparrow$ & & & & & 0.9 & 1.1 & 1.1 & 1.0 & 1.2 & 1.6 & 1.1 & 6 \\
\hline BeE120N21G10 & Q92356 & Synaptobrevin homolog 1 & & & & & & 0.9 & 1.2 & 1.0 & 1.1 & 1.2 & 1.3 & 1.4 & 4 \\
\hline BeE30N21E06 & & cation efflux protein/zinc transporter & & & & & & 1.3 & 1.1 & 1.0 & 0.8 & 0.6 & 0.7 & 0.7 & 5 \\
\hline BeE90D07E03 & 015258 & RER1 protein & & & & & & 1.0 & 1.1 & 1.0 & 1.4 & 1.4 & 1.4 & 1.7 & 4 \\
\hline BeE90D08C11 & & $\mathrm{ABC}$ transporter 7 protein & & & & & & 1.1 & 0.9 & 1.1 & 1.0 & 1.2 & 1.0 & 0.7 & 5 \\
\hline BeG30N13H08 & Q9JL97 & GPI-anchored ceruloplasmin & & & & & & 1.1 & 1.0 & 1.1 & 0.8 & 0.6 & & 0.7 & 5 \\
\hline BeG30N19E11 & & zinc/iron permease & & & & & & 1.0 & 1.6 & 1.1 & 0.5 & 0.6 & 1.0 & 0.6 & 5 \\
\hline BeZSPN09D06 & & hypothetical protein FG08884.1 & & & & & & 1.0 & 1.0 & 1.0 & 0.9 & 1.1 & 1.1 & 1.4 & 4 \\
\hline \multirow[t]{2}{*}{ BeZSPN17H06 } & & amino acid permease-associated region & & & & & & & 1.0 & 0.8 & 0.8 & 0.6 & 1.0 & 0.8 & 5 \\
\hline & & \multicolumn{14}{|l|}{ Transposição } \\
\hline BeE60H29B05 & & Putative transposase & $\downarrow$ & & & & & 1.0 & 0.7 & 0.9 & 0.9 & 0.6 & 0.5 & 1.1 & 2 \\
\hline BeZSPN17B12 & & Putative transposase & $\downarrow$ & & & & & 0.9 & 0.8 & 0.8 & 0.9 & 0.7 & 0.6 & 1.2 & 2 \\
\hline \multicolumn{16}{|c|}{ Outros } \\
\hline BeE30N07B02 & & Calmodulin (CaM) & $\downarrow$ & 0.6 & 0.8 & & & & & & & & & & \\
\hline BeE30N17E06 & Q7RZV & Hypothetical protein & $\downarrow$ & 0.6 & 0.8 & 0.9 & 1 & & & & & & & & \\
\hline BeE30N18B10 & & Hypothetical protein & $\downarrow$ & 0.5 & 0.8 & 1.0 & 1 & & & & & & & & \\
\hline BeE60C05B10 & Q882A7 & Oxidoreductase, Gfo/Idh/MocA family & $\downarrow$ & 0.5 & 0.7 & 0.9 & 1 & & & & & & & & \\
\hline BeE60C06H06 & Q7WWT9 & Putative NagM-like protein & $\downarrow$ & 0.7 & 0.7 & 0.8 & 4 & & & & & & & & \\
\hline BeE60C15B06 & Q91264 & Fe2+-dicitrate sensor & $\downarrow$ & 0.3 & 0.9 & 0.8 & 2 & & & & & & & & \\
\hline BeE60C25F11 & & hypothetical protein & $\downarrow$ & & 0.5 & 1.2 & & & & & & & & & \\
\hline BeE60C26F01 & & Hypothetical protein & $\downarrow$ & 0.6 & 0.8 & 0.8 & 1 & & & & & & & & \\
\hline BeE60H03A09 & & Hypothetical protein & $\downarrow$ & 0.7 & 0.7 & 1.1 & 1 & & & & & & & & \\
\hline BeE60N16C10 & & fiber protein Fb27 [Gossypium barbadense] & $\downarrow$ & 0.1 & 0.9 & 0.9 & 2 & & & & & & & & \\
\hline
\end{tabular}


BeE60N18G11

BeE90N19D05

BeE9ON2OHO7

BeG120N20D07

BeG30N06B11

BeG60N01F08

BeG90N03C01

BeE120N27B06

BeE60H31F05

BeE60N16C07

BeE9ON06H03

BeG120N02B04

BeG30N06H12

BeG30N14H06

BeG30N20D08

BeG60N08E04

BeE30N06D09

BeE30N13C08

BeE60N13A07

BeE60N16E08

BeE60N17D11

BeE60N19G04

BeG30N05D12

BeG30N06D12

BeG60N12C04

BeG60N19A03

BeZSPN15C05

BeE120N37B07

BeE30N02D01

BeE30N2OC05

$\mathrm{BeE60H32A03}$

BeE60N03D02

BeE60N07D03

BeE60N10G01

BeE60N11C12

BeE60N15F12

BeE90N05B08

BeG30N10E08

BeG30N14G08

BeG90N10E12

BeNSVP03D05

BeNSVP06B04

BeZSPN10A09

BeZSPN14F11

BeZSPN16C07

BeE30N07B04

BeE60N13B06

BeG120N23D09

BeZSPN05D01

BeZSPN10F11

BeE120N38E10

BeE3ONO2H12

BeE30N05H08

BeG90N06G12

BeE120N27E09 BeZSPN10C05

BeE60N08B01 bud site selection-related protein, putative [Cryp

similar to abhydrolase domain containing 11

Putative hydrolase

Hypothetical $39.5 \mathrm{kDa}$ protein

Hypothetical protein

hypothetical protein AN1230.2 [Aspergillus nidulan

zinc finger protein, putative [Cryptococcus neofor

Conserved hypothetical protein

pyrimidine 5 '-nucleotidase, putative

similar to DC6

similar to armadillo repeat containing 4

Hydrolase

Diphthine synthase

Gastric cancer antigen Zg14 (Fragment)

hypothetical protein CNBN1570

Q9UUG1 Brix domain containing protein 1 homolog

O42468 PP2A inhibitor

$\mathrm{N}$-alpha-acetyltransferase major subunit

Q91V01 Putative transmembrane protein

P53011 Nuclear pore protein SEH1

required for meiotic nuclear division 5 homolog $\mathrm{A}$

014220 Meiotic expression up-regulated protein 26

similar to PRIP-interacting protein PIPMT

protein arginine $n$-methyltransferase 1

P38783

P53738

Hypothetical $15.3 \mathrm{kDa}$ protein in MED6-VMA22

Hypothetical $15.1 \mathrm{kDa}$ protein in PET494MSO

Q9W3Y0 RE14402p Zinc finger protein

Q09919 Hypothetical protein C1F7.07c in chromosome

Q9C5

P97834

Q7YZR8

Q83L76

Dpy-30-like protein

Vacuolar protein sorting-associated protein 26

COP9 signalosome complex subunit 1

ferritin GF2

putative phosphohydrolase

Hypothetical protein

$094453 \quad$ Ubiquinone biosynthesis protein $\mathrm{COQ} 4$

Q7S952 Hypothetical protein

Hypothetical protein

hypothetical protein UM01058.1 [Ustilago maydis 52

Q9251

Hypothetical RING finger protein

Q7XJ13 Chloroplast nucleoid DNA-binding protein-li

Q7SEL5 Hypothetical protein

Q7S9X7 Hypothetical protein

Hypothetical protein

Hypothetical protein

Q8AVD5 Similar to Benzodiazepin receptor

Q9251 similar to Ring finger protein 121

P53326 Hypothetical 81.2 kDa protein in MES1-FOL2

Q8AVD5 Similar to Benzodiazepin receptor

putative protein disulfate isomerase

similar to Protein Mo25 (dMo25)

Multitransmembrane protein (ISS)

hypothetical protein [Strongylocentrotus purpuratus]

Hypothetical protein

hypothetical protein [Mycobacterium vanbaalenii]

acyl-coA-binding protein, ACBP

Regulator of G-protein signaling 5

Putative splicing factor

088848 ADP-ribosylation factor-like protein 6

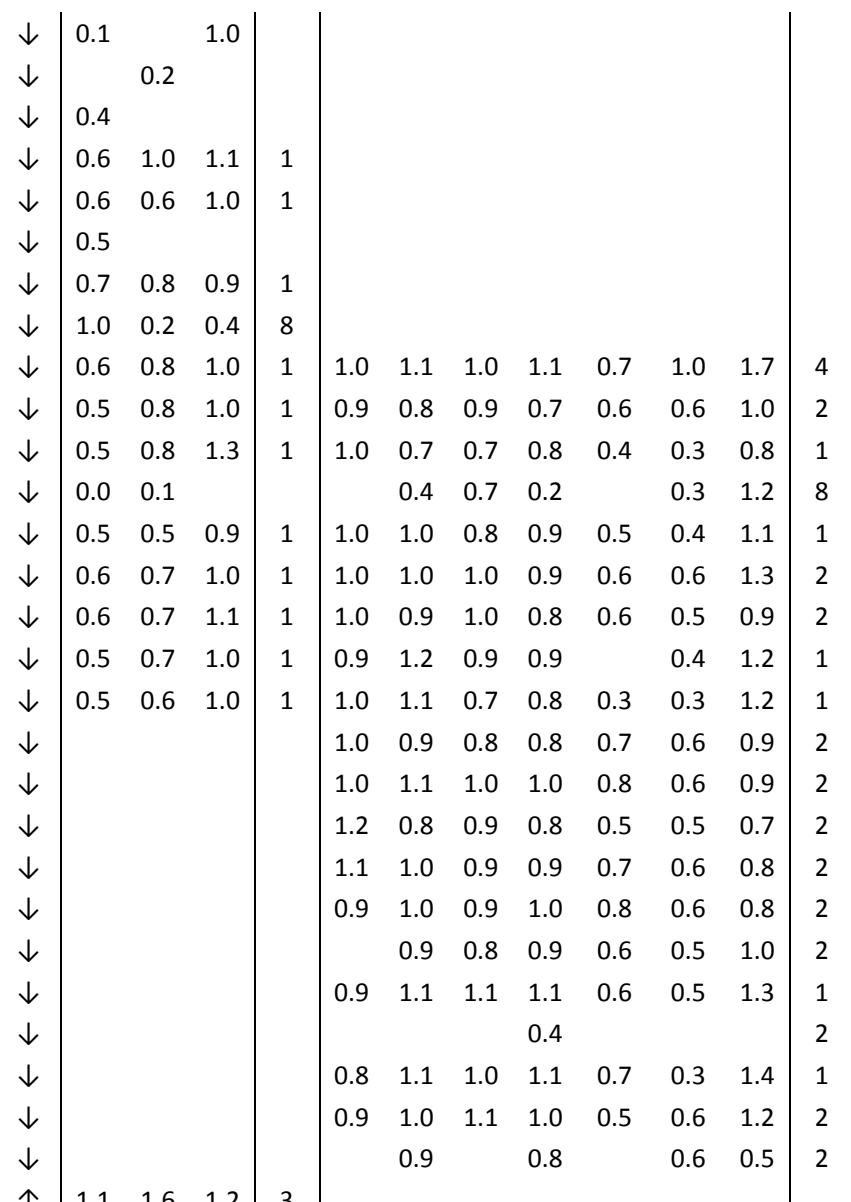

\begin{tabular}{llll|l}
$\uparrow$ & 1.1 & 1.6 & 1.2 & 3
\end{tabular}

\begin{tabular}{l|lll|l}
$\uparrow$ & 1.8 & 1.6 & 1.0 & 5
\end{tabular}

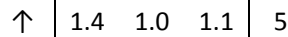

\begin{tabular}{l|lll|l}
$\uparrow$ & 1.7 & 1.3 & 0.7 & 5
\end{tabular}

\begin{tabular}{llll|l}
$\uparrow$ & 1.4 & 1.3 & 1.1 & 3
\end{tabular}

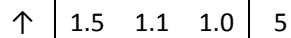

\begin{tabular}{llll|l}
$\uparrow$ & 1.8 & 1.5 & 1.0 & 5
\end{tabular}

\begin{tabular}{llll|l}
$\uparrow$ & 1.4 & 1.2 & 1.2 & 3
\end{tabular}

\begin{tabular}{l|lll|l}
$\uparrow$ & 2.1 & 1.8 & 1.0 & 5
\end{tabular}

\begin{tabular}{llll|l}
$\uparrow$ & 1.4 & 1.4 & 1.0 & 3
\end{tabular}

\begin{tabular}{llll|l}
$\uparrow$ & 1.5 & 1.2 & 0.9 & 5
\end{tabular}

$\begin{array}{llll}\uparrow & 1.2 & 0.2\end{array}$

\begin{tabular}{llll|l}
$\uparrow$ & 1.3 & 2.0 & 0.9 & 3
\end{tabular}

$\begin{array}{lllll}\uparrow & 1.2 & 2.3 & 2.2 & 3\end{array}$

个 $\quad 2.3 \quad 1.2$

$\uparrow 1.5$

$\uparrow 1.6$

$\uparrow \quad 1.6$

\begin{tabular}{llll|l|lllllll|l}
$\uparrow$ & 1.7 & 1.4 & 0.9 & 5 & 1.0 & 1.0 & 1.2 & 1.7 & 2.4 & 2.8 & 1.4 & 7
\end{tabular}

$\uparrow \quad \begin{array}{lll}1.7 & 1.4 & 0.9 \\ 2.2 & 1.8 & \end{array}$

$\uparrow$\begin{tabular}{lll|l}
1.5 & 1.8 & 1.1 & 3
\end{tabular}

$\uparrow \begin{array}{lll}1.8 & 1.2\end{array}$

$\uparrow \quad 1.7 \quad 1.3$

$\uparrow$

$\uparrow$

$\uparrow$

$\uparrow$

1.11 .3

$\begin{array}{ll}1.5 & 1.5 \\ & 0.5\end{array}$

$\begin{array}{lllllll}1.0 & 1.0 & 1.2 & 1.7 & 2.4 & 2.8 & 1.4 \\ 1.0 & 0.9 & 0.8 & 1.1 & 1.5 & 2.1 & 0.7\end{array}$

$\begin{array}{lllllllll}1.0 & 1.2 & 1.2 & 1.5 & 1.9 & 1.6 & 0.8 & 6\end{array}$

\begin{tabular}{llllllll|l}
0.9 & 1.2 & 1.0 & 1.3 & 1.5 & 1.9 & 1.0 & 6
\end{tabular}

\begin{tabular}{llllllll|l}
1.1 & 1.1 & 1.1 & 1.5 & 1.7 & 1.6 & 1.1 & 6
\end{tabular}

\begin{tabular}{lllllll|l}
0.9 & 1.2 & 1.4 & 1.4 & 1.3 & 1.7 & 1.2 & 6
\end{tabular}

\begin{tabular}{llllllll|l}
1.0 & 0.8 & 1.0 & 1.1 & 1.2 & 1.6 & 1.0 & 6
\end{tabular}

\begin{tabular}{llllllll|l}
0.9 & 1.1 & 1.2 & 1.3 & 1.6 & 1.6 & 1.0 & 6
\end{tabular}

\begin{tabular}{lllllll|l}
1.0 & 1.1 & 1.2 & 1.5 & 1.6 & 1.5 & 1.0 & 6
\end{tabular}

\begin{tabular}{lllllll|l}
1.1 & 1.4 & 0.9 & 1.3 & 1.3 & 1.3 & 1.3 & 4
\end{tabular}

$\begin{array}{lll}0.9 & 1.4 & 1.1\end{array}$

1. 


\begin{tabular}{|c|c|c|c|c|c|c|c|c|c|c|c|c|c|c|c|}
\hline \multirow{2}{*}{$\begin{array}{l}\text { BeZSPN10F01 } \\
\text { BeE120N04E04 }\end{array}$} & & Hypothetical protein & & \multicolumn{2}{|l|}{1.0} & \multicolumn{2}{|l|}{0.4} & \multirow[b]{2}{*}{1.0} & \multirow[b]{2}{*}{1.4} & \multirow[b]{2}{*}{1.0} & \multirow[b]{2}{*}{1.1} & \multirow[b]{2}{*}{1.0} & \multirow[b]{2}{*}{0.8} & \multirow[b]{2}{*}{1.4} & \multirow[b]{2}{*}{4} \\
\hline & & hypothetical protein & & & & & & & & & & & & & \\
\hline BeE30N04B08 & & similar to intersectin 2 isoform 3 & & & & & & 0.9 & 1.4 & 1.0 & 1.0 & 1.0 & 1.3 & 1.3 & 4 \\
\hline BeE30N15E12 & & $20 S$ proteasome beta subunit & & & & & & 1.0 & 1.0 & 0.9 & 1.0 & 1.0 & 1.5 & 0.6 & 5 \\
\hline BeG120N21E09 & & putative translation factor & & & & & & & 1.5 & 1.6 & 0.7 & & & 0.5 & 5 \\
\hline BeG30N02F07 & Q9UU79 & SPCP1E11.08 protein & & & & & & 0.9 & 1.5 & 1.1 & 1.3 & 1.1 & 1.2 & 1.8 & 4 \\
\hline BeG30N18D12 & Q9D2E2 & Target of EGR1 protein 1 & & & & & & & 1.4 & & 1.0 & & & & 5 \\
\hline BeG9ON04H09 & P72926 & Hypothetical protein sll1024 & & & & & & 1.0 & 1.3 & 1.4 & 1.5 & 1.3 & 1.1 & 1.3 & 4 \\
\hline BeZSPN16A08 & P40157 & Vacuolar import and degradation protein 27 & & & & & & 1.0 & 1.5 & 1.2 & 1.3 & 1.2 & 1.3 & 1.5 & 4 \\
\hline & & No Match & & & & & & & & & & & & & \\
\hline BeE120N02E01 & & No match & $\downarrow$ & 0.6 & 0.8 & 0.8 & 1 & & & & & & & & \\
\hline BeE120N04A06 & & No match & $\downarrow$ & & 0.6 & 1.2 & & & & & & & & & \\
\hline BeE120N20E11 & & No match & $\downarrow$ & 0.9 & 0.4 & 0.8 & 4 & & & & & & & & \\
\hline BeE120N28D05 & & No match & $\downarrow$ & 0.0 & 0.2 & 0.2 & 7 & & & & & & & & \\
\hline BeE120N29D12 & & No match & $\downarrow$ & 0.6 & 0.7 & 1.1 & 1 & & & & & & & & \\
\hline BeE120N34E05 & & No match & $\downarrow$ & 0.0 & 1.0 & 1.1 & 7 & & & & & & & & \\
\hline BeE30N06A02 & & No match & $\downarrow$ & 0.6 & 0.9 & 0.9 & 1 & & & & & & & & \\
\hline BeE30N06H08 & & No match & $\downarrow$ & 0.7 & 0.9 & 1.2 & 1 & & & & & & & & \\
\hline BeE30N17F07 & & No match & $\downarrow$ & 0.7 & 0.7 & 1.0 & 1 & & & & & & & & \\
\hline BeE30N18A10 & & No match & $\downarrow$ & 0.6 & 1.1 & 1.0 & 1 & & & & & & & & \\
\hline BeE30N21E07 & & No match & $\downarrow$ & 0.4 & 1.0 & 0.9 & 1 & & & & & & & & \\
\hline BeE60C05A01 & & No match & $\downarrow$ & 0.6 & 0.8 & 0.8 & 1 & & & & & & & & \\
\hline BeE60C14C08 & & No match & $\downarrow$ & 1.0 & 0.7 & 0.9 & 4 & & & & & & & & \\
\hline BeE60C19F04 & & No match & $\downarrow$ & 0.4 & 1.0 & 1.2 & 1 & & & & & & & & \\
\hline $\mathrm{BeE} 60 \mathrm{H} 24 \mathrm{~F} 02$ & & No match & $\downarrow$ & 0.7 & 0.8 & 1.0 & 1 & & & & & & & & \\
\hline $\mathrm{BeE60H26E03}$ & & No match & $\downarrow$ & 0.6 & 0.8 & 1.0 & 1 & & & & & & & & \\
\hline BeE60H26F07-1 & & No match & $\downarrow$ & 0.8 & & 0.3 & & & & & & & & & \\
\hline BeE60N03A10 & & No match & $\downarrow$ & & 0.7 & 0.6 & & & & & & & & & \\
\hline BeE60N10A10 & & No match & $\downarrow$ & 0.5 & & & & & & & & & & & \\
\hline BeE60N11G03 & & No match & $\downarrow$ & 0.5 & 1.0 & 1.1 & 1 & & & & & & & & \\
\hline BeE60N14B10 & & No match & $\downarrow$ & 0.9 & 0.7 & 0.7 & 4 & & & & & & & & \\
\hline BeE60N19B06 & & No match & $\downarrow$ & 0.4 & 0.9 & 0.9 & 1 & & & & & & & & \\
\hline BeE60N19C08 & & No match & $\downarrow$ & 0.4 & 1.1 & & & & & & & & & & \\
\hline BeE60N19C09 & & No match & $\downarrow$ & 0.6 & 0.5 & 0.4 & 4 & & & & & & & & \\
\hline BeE90D03F09 & & No match & $\downarrow$ & 0.7 & 0.8 & 0.7 & 4 & & & & & & & & \\
\hline BeE90D04A05 & & No match & $\downarrow$ & 0.7 & 0.9 & 0.9 & 1 & & & & & & & & \\
\hline BeE90D04A06 & & No match & $\downarrow$ & 0.8 & 0.6 & 0.8 & 4 & & & & & & & & \\
\hline BeE90D15G11 & & No match & $\downarrow$ & 1.0 & 0.8 & 0.6 & 4 & & & & & & & & \\
\hline BeE90N07E01 & & No match & $\downarrow$ & 0.6 & 1.0 & 1.0 & 1 & & & & & & & & \\
\hline BeE90N07F02 & & No match & $\downarrow$ & 0.3 & 0.9 & 1.3 & 2 & & & & & & & & \\
\hline BeE90N07H12 & & No match & $\downarrow$ & 0.5 & 0.8 & 0.7 & 1 & & & & & & & & \\
\hline BeE90N12G06 & & No match & $\downarrow$ & 0.4 & 0.8 & 0.8 & 2 & & & & & & & & \\
\hline BeE90N13D06 & & No match & $\downarrow$ & 0.2 & 1.2 & 1.0 & 2 & & & & & & & & \\
\hline BeG120N07D05 & & No match & $\downarrow$ & & 0.4 & 0.4 & & & & & & & & & \\
\hline BeG120N12C07 & & No match & $\downarrow$ & 0.8 & & 0.4 & & & & & & & & & \\
\hline BeG120N15D09 & & No match & $\downarrow$ & 0.6 & & & & & & & & & & & \\
\hline
\end{tabular}




\begin{tabular}{|c|c|}
\hline BeG120N17B05 & No match \\
\hline BeG120N17E07 & No match \\
\hline BeG120N17E10 & No match \\
\hline BeG120N17G10 & No match \\
\hline BeG120N22B01 & No match \\
\hline BeG30N02G12 & No match \\
\hline BeG30N03E03 & No match \\
\hline BeG30N06B03 & No match \\
\hline BeG30N11A02 & No match \\
\hline BeG30N11D04 & No match \\
\hline BeG30N11H04 & No match \\
\hline BeG30N17B05 & No match \\
\hline BeG30N20D04 & No match \\
\hline BeG30N20G02 & No match \\
\hline BeG60N03C06 & No match \\
\hline BeG60N03E12 & No match \\
\hline BeG60N04H08 & No match \\
\hline BeG60N17H09 & No match \\
\hline BeG90N01E04 & No match \\
\hline BeG90N03D10 & No match \\
\hline BeG90N08D05 & No match \\
\hline BeG90N11E11 & No match \\
\hline BeG90N15A11 & No match \\
\hline BeG90N15H09 & No match \\
\hline BeG90N17B11 & No match \\
\hline BeG90N19A08 & No match \\
\hline BeG90N21C05 & No match \\
\hline BeNSVP09C09 & No match \\
\hline BeNSVPO9HOG & No match \\
\hline BeNSVP12G10 & No match \\
\hline BeZSPN08G10 & No match \\
\hline BeZSPN09E01 & No match \\
\hline BeZSPN10C06 & No match \\
\hline BeZSPN16H09 & No match \\
\hline BeZSPN17H12 & No match \\
\hline BeZSPN18D04 & No match \\
\hline BeE120N01C01 & No match \\
\hline BeE120N02C09 & No match \\
\hline BeE12ONO2H03 & No match \\
\hline BeE120N04C07 & No match \\
\hline BeE120N24E05 & No match \\
\hline BeE120N26B08 & No match \\
\hline BeE120N30F10 & No match \\
\hline BeE120N32B08 & No match \\
\hline BeE120N35B10 & No match \\
\hline BeE30N06F05 & No match \\
\hline BeE30N14E05 & No match \\
\hline BeE30N18D04 & No match \\
\hline BeE60C03D07 & No match \\
\hline BeE60C11C01 & No match \\
\hline BeE60H15D02 & No match \\
\hline BeE60N20E01 & No match \\
\hline BeE90D04G12 & No match \\
\hline BeE90D11H09 & No match \\
\hline BeG120N11D04 & No match \\
\hline BeG30N08A04 & No match \\
\hline BeG60N17D07 & No match \\
\hline BeG60N18C02 & No match \\
\hline
\end{tabular}

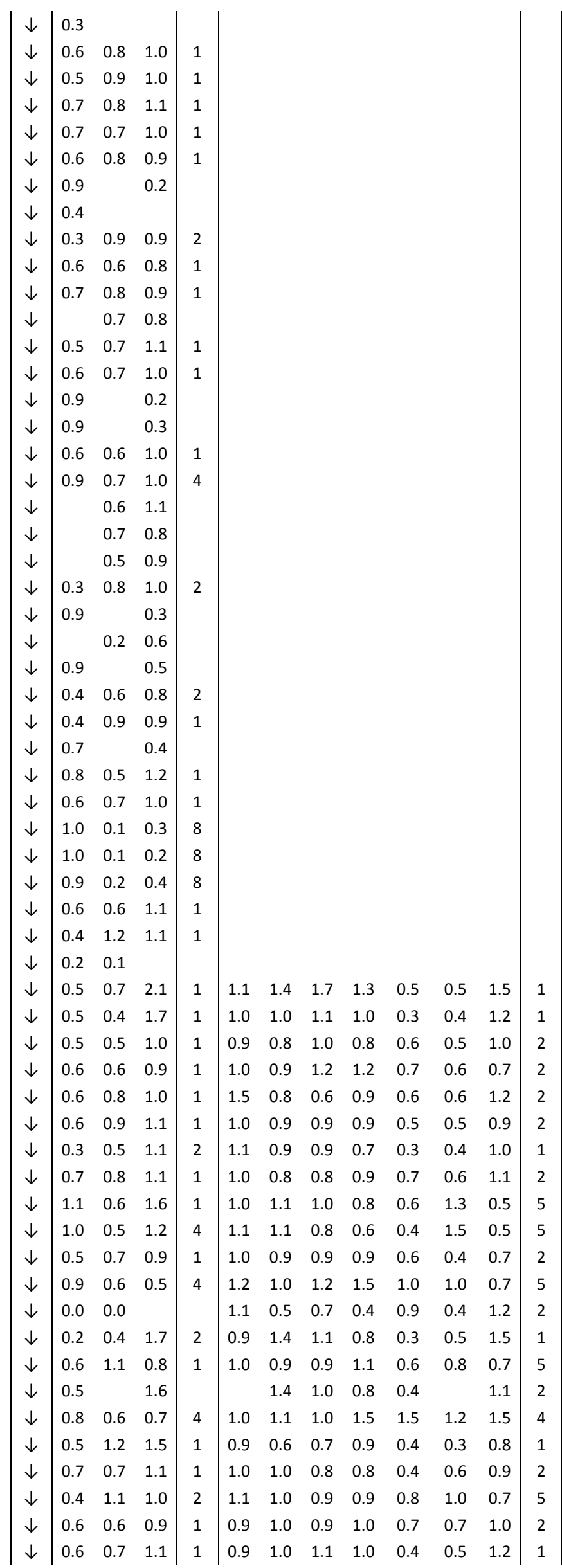




\begin{tabular}{|c|c|}
\hline BeG60N18G09 & No match \\
\hline BeG60N19C12 & No match \\
\hline BeG90N05D09 & No match \\
\hline BeG90N18G03 & No match \\
\hline BeNSVP04A06 & No match \\
\hline BeNSVP05B07 & No match \\
\hline BeNSVP09C06 & No match \\
\hline BeNSVP09E01 & No match \\
\hline BeE120N06E03 & No match \\
\hline BeE120N10H08 & No match \\
\hline BeE30N19C11 & No match \\
\hline BeE60C04F02 & No match \\
\hline ВеЕ60H09H11 & No match \\
\hline BeE60N04D07 & No match \\
\hline BeE60N05E11 & No match \\
\hline BeE60N05G03 & No match \\
\hline BeE60N17E03 & No match \\
\hline BeE90N14D02 & No match \\
\hline BeG120N14G12 & No match \\
\hline BeG120N15H09 & No match \\
\hline BeG120N22B10 & No match \\
\hline BeG30N12H05 & No match \\
\hline BeG60N06E08 & No match \\
\hline BeG60N14B04 & No match \\
\hline BeZSPN14B03 & No match \\
\hline BeE120N09C09 & No match \\
\hline BeE120N37E05 & No match \\
\hline BeE30N11D11 & No match \\
\hline BeE30N14D02 & No match \\
\hline BeE60C05C02 & No match \\
\hline BeE60C15G05 & No match \\
\hline BeE60C19A10 & No match \\
\hline BeE60C31A02-1 & No match \\
\hline BeE60H15D09 & No match \\
\hline ВеЕ60Н19B03 & No match \\
\hline BeE60N05D04 & No match \\
\hline BeE60N06C09 & No match \\
\hline BeE60N08D08 & No match \\
\hline BeE90D07H03 & No match \\
\hline BeE90D09B06 & No match \\
\hline BeE90D15C08 & No match \\
\hline BeE90N02A02 & No match \\
\hline BeE90N19A07 & No match \\
\hline BeE90N19F09 & No match \\
\hline BeG30N06C01 & No match \\
\hline BeG30N13G05 & No match \\
\hline BeG30N14B07 & No match \\
\hline BeG30N14C06 & No match \\
\hline BeG30N14H05 & No match \\
\hline BeG30N20D01 & No match \\
\hline BeG60N01F05 & No match \\
\hline BeG60N09D12 & No match \\
\hline BeNSVP06E02 & No match \\
\hline BeNSVP09G10 & No match \\
\hline BeNSVP11G01 & No match \\
\hline BeZSPN09B06 & No match \\
\hline BeZSPN15D04 & No match \\
\hline BeZSPN15F05 & No match \\
\hline
\end{tabular}

\begin{tabular}{|c|c|c|c|c|c|c|c|c|c|c|c|c|}
\hline$\downarrow$ & 0.5 & 0.9 & 1.2 & 1 & 0.9 & 0.9 & 0.8 & 0.5 & 0.4 & 0.3 & 0.7 & 1 \\
\hline$\downarrow$ & 0.4 & 0.7 & & & 1.0 & 1.0 & 0.9 & 0.7 & 0.7 & 0.5 & 1.1 & 2 \\
\hline$\downarrow$ & 0.5 & 0.6 & 0.9 & 1 & & 0.9 & 0.8 & 0.7 & 0.6 & 0.6 & 1.0 & 2 \\
\hline$\downarrow$ & 0.7 & 0.5 & 1.1 & 1 & 0.9 & 1.1 & 1.1 & 0.7 & 0.5 & 0.5 & 1.2 & 1 \\
\hline$\downarrow$ & 0.5 & 0.6 & 0.9 & 1 & 0.9 & 1.1 & 1.0 & 0.8 & 0.5 & 0.6 & 1.2 & 2 \\
\hline$\downarrow$ & 0.6 & 0.7 & 1.1 & 1 & & 1.1 & 1.1 & 0.8 & 0.9 & 0.6 & 1.3 & 2 \\
\hline$\downarrow$ & 0.6 & 0.8 & 1.2 & 1 & 0.9 & 1.0 & 0.9 & 0.9 & 0.5 & 0.4 & 1.5 & 1 \\
\hline$\downarrow$ & 0.2 & 0.8 & 2.5 & 2 & 1.0 & 0.5 & 0.4 & 0.3 & 0.2 & 0.2 & 0.4 & 8 \\
\hline$\downarrow$ & & & & & 1.1 & 0.8 & 1.1 & 0.9 & 0.9 & 0.7 & 0.8 & 2 \\
\hline$\downarrow$ & & & & & 1.0 & 0.8 & 0.7 & 0.7 & 0.6 & 0.6 & 0.9 & 2 \\
\hline$\downarrow$ & & & & & 1.1 & 1.1 & 0.9 & 0.9 & 0.8 & 0.6 & 1.3 & 2 \\
\hline$\downarrow$ & & & & & 0.9 & 0.9 & 1.0 & 0.8 & 0.7 & 0.6 & 0.8 & 2 \\
\hline$\downarrow$ & & & & & 1.0 & 0.8 & 1.0 & 0.9 & & 0.6 & 0.9 & 2 \\
\hline$\downarrow$ & & & & & 0.9 & 0.9 & 0.8 & 1.0 & 0.7 & 0.7 & 0.8 & 2 \\
\hline$\downarrow$ & & & & & 0.9 & 0.9 & 0.8 & 0.8 & 0.6 & 0.7 & 0.8 & 2 \\
\hline$\downarrow$ & & & & & 1.1 & 1.0 & 1.1 & 0.9 & 0.8 & 0.7 & 0.9 & 2 \\
\hline$\downarrow$ & & & & & 1.0 & 0.9 & 1.0 & 1.0 & 0.8 & 0.6 & 0.7 & 2 \\
\hline$\downarrow$ & & & & & 1.0 & 1.0 & 1.0 & 1.0 & 0.6 & 0.5 & 0.6 & 2 \\
\hline$\downarrow$ & & & & & 1.1 & 1.2 & 1.1 & 1.0 & 0.5 & 0.7 & 1.2 & 2 \\
\hline$\downarrow$ & & & & & & & & & & & 0.5 & 1 \\
\hline$\downarrow$ & & & & & 1.1 & 0.9 & 0.7 & 0.7 & 0.6 & 0.5 & 0.7 & 2 \\
\hline$\downarrow$ & & & & & & 0.9 & & 0.6 & 0.9 & 0.8 & 1.0 & 2 \\
\hline$\downarrow$ & & & & & 0.9 & 0.8 & 0.8 & 0.7 & 0.7 & 0.8 & 0.8 & 2 \\
\hline$\downarrow$ & & & & & 0.9 & 1.0 & 1.0 & 0.8 & 0.7 & 0.6 & 1.0 & 2 \\
\hline$\downarrow$ & & & & & 1.0 & 1.0 & 0.9 & 0.7 & 0.9 & 0.6 & 0.9 & 2 \\
\hline$\uparrow$ & 1.2 & 1.6 & 0.7 & 3 & & & & & & & & \\
\hline$\uparrow$ & 1.5 & 1.6 & 1.0 & 3 & & & & & & & & \\
\hline$\uparrow$ & 1.5 & 1.1 & 1.0 & 5 & & & & & & & & \\
\hline$\uparrow$ & 1.4 & 1.2 & 0.9 & 5 & & & & & & & & \\
\hline$\uparrow$ & 1.3 & 1.2 & 0.8 & 5 & & & & & & & & \\
\hline$\uparrow$ & 2.3 & 1.1 & 0.7 & 5 & & & & & & & & \\
\hline$\uparrow$ & 1.4 & 1.2 & 0.8 & 5 & & & & & & & & \\
\hline$\uparrow$ & 2.0 & 1.4 & 0.6 & 5 & & & & & & & & \\
\hline$\uparrow$ & 1.6 & 1.4 & 0.9 & 5 & & & & & & & & \\
\hline$\uparrow$ & 1.0 & 1.4 & 1.5 & 3 & & & & & & & & \\
\hline$\uparrow$ & 1.5 & 1.1 & 1.0 & 5 & & & & & & & & \\
\hline$\uparrow$ & 1.2 & 1.5 & 1.1 & 3 & & & & & & & & \\
\hline$\uparrow$ & 1.5 & 1.4 & 1.1 & 3 & & & & & & & & \\
\hline$\uparrow$ & 1.2 & 1.5 & 1.0 & 3 & & & & & & & & \\
\hline$\uparrow$ & 1.2 & 1.6 & 1.1 & 3 & & & & & & & & \\
\hline$\uparrow$ & 4.1 & 3.0 & 0.5 & 6 & & & & & & & & \\
\hline$\uparrow$ & 1.3 & 0.8 & 0.8 & 4 & & & & & & & & \\
\hline$\uparrow$ & 1.7 & 1.3 & 0.8 & 5 & & & & & & & & \\
\hline$\uparrow$ & 1.9 & 0.9 & 0.8 & 5 & & & & & & & & \\
\hline$\uparrow$ & 1.4 & 1.2 & 0.9 & 5 & & & & & & & & \\
\hline$\uparrow$ & 2.7 & 1.5 & 0.9 & 5 & & & & & & & & \\
\hline$\uparrow$ & 2.0 & 1.0 & 1.1 & 5 & & & & & & & & \\
\hline$\uparrow$ & 1.2 & & 0.2 & & & & & & & & & \\
\hline$\uparrow$ & 2.8 & 1.3 & 1.0 & 5 & & & & & & & & \\
\hline$\uparrow$ & 1.2 & & 0.4 & & & & & & & & & \\
\hline$\uparrow$ & 1.7 & & 0.1 & & & & & & & & & \\
\hline$\uparrow$ & 1.4 & 1.2 & 0.7 & 5 & & & & & & & & \\
\hline$\uparrow$ & & 1.8 & & & & & & & & & & \\
\hline$\uparrow$ & 1.2 & & 0.5 & & & & & & & & & \\
\hline$\uparrow$ & 1.2 & & 0.3 & & & & & & & & & \\
\hline$\uparrow$ & 1.2 & 0.3 & 0.4 & 8 & & & & & & & & \\
\hline$\uparrow$ & 1.2 & & 0.4 & & & & & & & & & \\
\hline$\uparrow$ & 1.9 & & 0.6 & & & & & & & & & \\
\hline
\end{tabular}




\begin{tabular}{|c|c|}
\hline BeZSPN15H07 & No match \\
\hline BeZSPN15H09 & No match \\
\hline BeZSPN16E03 & No match \\
\hline BeZSPN16G12 & No match \\
\hline BeE120N20F10 & No match \\
\hline BeE120N28C06 & No match \\
\hline BeE12ON28H09 & No match \\
\hline BeE120N35C12 & No match \\
\hline BeE3ON02C02 & No match \\
\hline BeE3ON04H12 & No match \\
\hline BeE30N06E10 & No match \\
\hline BeE30N14F05 & No match \\
\hline BeE30N16A03 & No match \\
\hline BeE30N20B08 & No match \\
\hline BeE60C32F10 & No match \\
\hline BeE60C34B10 & No match \\
\hline BeE60H05E07 & No match \\
\hline BeE60H08F12 & No match \\
\hline BeE60N01B04 & No match \\
\hline BeE60N01C08 & No match \\
\hline BeE60N12C04 & No match \\
\hline BeE60N13B09 & No match \\
\hline BeE60N18B07 & No match \\
\hline BeE90D05F08 & No match \\
\hline BeE90D17D01 & No match \\
\hline BeG3ON02F02 & No match \\
\hline BeG30N09F03 & No match \\
\hline BeG60N20A07 & No Match \\
\hline BeG90N03G03 & No match \\
\hline BeZSPN03D11 & No match \\
\hline BeZSPN07B12 & No match \\
\hline BeZSPN09F05 & No match \\
\hline BeZSPN15E10 & No match \\
\hline BeE120N36E08 & No match \\
\hline BeE60C14A09 & No match \\
\hline BeE60C24H02 & No match \\
\hline BeE60H15G12 & No match \\
\hline $\mathrm{BeE60H26G08}$ & No match \\
\hline BeE90D14D07 & No match \\
\hline BeG120N09E12 & No match \\
\hline BeG30N06A12 & No match \\
\hline BeG30N13C07 & No match \\
\hline BeNSVP07F06 & No match \\
\hline BeNSVP12C06 & No match \\
\hline BeZSPN02B03 & No match \\
\hline BeZSPN02C06 & No match \\
\hline BeZSPN02G02 & No match \\
\hline BeZSPN03B07 & No match \\
\hline BeZSPN03D08 & No match \\
\hline BeZSPNO3E07 & No match \\
\hline BeZSPN11B10 & No match \\
\hline BeZSPN12D03 & No match \\
\hline BeZSPN17D01 & No match \\
\hline BeG120N10C05 & No match \\
\hline BeG60N06H10 & No match \\
\hline BeE120N20C04 & No match \\
\hline BeE60N06F03 & No match \\
\hline BeG120N14B03 & No match \\
\hline
\end{tabular}

\begin{tabular}{|c|c|c|c|c|c|c|c|c|c|c|c|c|}
\hline 个 & & 1.4 & 1.1 & & & & & & & & & \\
\hline 个 & 1.2 & & 0.1 & & & & & & & & & \\
\hline 个 & 1.2 & & 0.3 & & & & & & & & & \\
\hline 个 & 1.8 & 1.1 & 0.8 & 5 & & & & & & & & \\
\hline$\uparrow$ & 1.8 & & 1.0 & & 1.0 & 1.1 & 1.3 & 1.3 & 1.4 & 1.5 & 1.2 & 6 \\
\hline$\uparrow$ & 2.2 & 1.5 & 0.8 & 5 & 1.0 & 1.4 & 1.0 & 1.1 & 2.0 & 1.9 & 0.4 & 6 \\
\hline$\uparrow$ & 1.0 & 1.4 & 1.1 & 3 & 1.1 & 1.1 & 1.3 & 1.2 & 1.4 & 1.5 & 1.0 & 6 \\
\hline$\uparrow$ & 1.4 & & & & 1.1 & 1.2 & 1.0 & 1.2 & 1.4 & 1.5 & 1.1 & 6 \\
\hline$\uparrow$ & 5.7 & 2.9 & 0.7 & 6 & 0.9 & 1.3 & 1.3 & 1.4 & 3.8 & 4.3 & 0.6 & 3 \\
\hline$\uparrow$ & 1.0 & 1.5 & 1.0 & 3 & 0.9 & 0.7 & 1.0 & 0.9 & 1.1 & 1.5 & 0.9 & 6 \\
\hline$\uparrow$ & 2.0 & 1.8 & 0.8 & 5 & 1.0 & 1.1 & 0.8 & 1.0 & 1.5 & 1.6 & 0.8 & 6 \\
\hline$\uparrow$ & 2.1 & 1.6 & 0.9 & 5 & 1.0 & 1.3 & 1.5 & 2.1 & 3.5 & 4.0 & 1.1 & 7 \\
\hline$\uparrow$ & 1.6 & 1.1 & 0.8 & 5 & 1.0 & 1.0 & 1.1 & 1.5 & 1.9 & 1.9 & 1.0 & 6 \\
\hline$\uparrow$ & 1.7 & 1.7 & 1.0 & 3 & 1.0 & 1.3 & 1.5 & 2.4 & 2.4 & 3.2 & 1.1 & 7 \\
\hline$\uparrow$ & 3.9 & 2.2 & 0.9 & 6 & 0.9 & 1.4 & 1.3 & 2.4 & 4.0 & 3.9 & 0.8 & 7 \\
\hline$\uparrow$ & 1.6 & 1.3 & 0.6 & 5 & 1.0 & 1.0 & 0.7 & 0.9 & 1.0 & 1.0 & 0.5 & 5 \\
\hline$\uparrow$ & 1.8 & 1.7 & & & 1.0 & 1.1 & 1.1 & 1.6 & 4.8 & 3.8 & 1.3 & 7 \\
\hline$\uparrow$ & 8.1 & 3.5 & 0.4 & 6 & 0.9 & 1.1 & 0.9 & 1.3 & 4.5 & 15.8 & 0.6 & 3 \\
\hline$\uparrow$ & 3.3 & 1.7 & 1.0 & 6 & 0.9 & 1.1 & 1.6 & 3.1 & 7.6 & 5.5 & 1.7 & 7 \\
\hline$\uparrow$ & 1.0 & 1.7 & 1.1 & 3 & 1.0 & 1.0 & 1.0 & 1.1 & 1.2 & 1.5 & 0.9 & 6 \\
\hline$\uparrow$ & & 1.5 & 1.1 & & 0.9 & 1.4 & 1.1 & 1.3 & 1.6 & 1.7 & 1.4 & 4 \\
\hline$\uparrow$ & 1.4 & 2.1 & 1.5 & 3 & 1.1 & 1.0 & 0.8 & 0.9 & 1.1 & 1.1 & 0.6 & 5 \\
\hline$\uparrow$ & 2.2 & 1.6 & 1.0 & 5 & 1.0 & 1.4 & 1.4 & 1.7 & 3.7 & 4.4 & 1.3 & 7 \\
\hline$\uparrow$ & 5.8 & 2.4 & 0.5 & 6 & 1.1 & 1.0 & 0.6 & 1.3 & 4.3 & 4.5 & 0.6 & 3 \\
\hline$\uparrow$ & 1.4 & 1.9 & 0.5 & 5 & & & & 1.0 & & 5.6 & & 3 \\
\hline$\uparrow$ & 1.6 & 1.8 & & & 1.0 & 1.2 & 1.2 & 1.3 & 1.6 & 2.0 & 1.1 & 6 \\
\hline$\uparrow$ & 1.3 & 1.4 & 1.3 & 3 & 0.9 & 1.4 & 1.2 & 1.4 & 1.2 & 1.4 & 1.4 & 4 \\
\hline$\uparrow$ & 1.4 & 1.4 & 0.7 & 5 & 1.1 & 0.9 & 1.2 & 1.2 & 1.4 & 1.1 & 0.5 & 6 \\
\hline$\uparrow$ & 2.3 & 2.0 & 1.3 & 3 & 1.1 & 1.1 & 1.2 & 1.3 & 1.5 & 1.9 & 0.7 & 6 \\
\hline 个 & 1.0 & 1.8 & 1.2 & 3 & 0.8 & 0.7 & 1.1 & 0.9 & 1.3 & 1.7 & 0.8 & 6 \\
\hline 个 & 2.0 & 1.1 & 0.8 & 5 & 1.0 & 1.2 & 1.2 & 1.3 & 1.4 & 1.6 & 1.0 & 6 \\
\hline$\uparrow$ & 0.9 & 0.2 & 0.4 & 8 & 0.9 & 0.8 & 1.1 & 1.0 & 1.1 & 1.4 & 0.9 & 6 \\
\hline$\uparrow$ & 1.4 & 1.5 & 1.2 & 3 & 0.9 & 1.5 & 1.3 & 1.6 & 1.4 & 1.5 & 1.6 & 4 \\
\hline$\uparrow$ & & & & & 1.1 & 1.1 & 0.9 & 1.1 & 1.4 & 1.8 & 0.9 & 6 \\
\hline 个 & & & & & 1.0 & 1.1 & & 1.3 & 1.6 & 2.0 & 1.2 & 6 \\
\hline 个 & & & & & 1.2 & 0.8 & 1.1 & 1.4 & 3.5 & 2.5 & 0.8 & 7 \\
\hline$\uparrow$ & & & & & 1.1 & 0.9 & 1.1 & 1.1 & 1.3 & 1.4 & 0.9 & 6 \\
\hline$\uparrow$ & & & & & 1.1 & 0.9 & 1.0 & 1.1 & 1.3 & 1.9 & 0.9 & 6 \\
\hline 个 & & & & & 1.1 & 1.0 & 1.1 & 0.9 & 1.5 & 2.3 & 0.8 & 6 \\
\hline$\uparrow$ & & & & & 1.0 & 1.2 & 1.1 & 1.2 & 1.7 & 1.6 & 1.1 & 6 \\
\hline 个 & & & & & 1.0 & 1.2 & 1.2 & 1.4 & 1.5 & 1.6 & 1.1 & 6 \\
\hline$\uparrow$ & & & & & 0.9 & 1.2 & 1.0 & 1.1 & 1.2 & 1.5 & 1.1 & 6 \\
\hline 个 & & & & & 0.8 & 0.9 & 1.1 & 1.3 & 1.6 & 2.0 & 1.0 & 6 \\
\hline$\uparrow$ & & & & & 1.0 & 1.1 & 1.1 & 1.1 & 1.3 & 1.2 & 1.0 & 6 \\
\hline 个 & & & & & 0.9 & 1.0 & 1.0 & 1.2 & 1.4 & 1.7 & 1.0 & 6 \\
\hline$\uparrow$ & & & & & 0.9 & 1.0 & 0.9 & 1.0 & 1.1 & 1.5 & 0.9 & 6 \\
\hline 个 & & & & & 0.9 & 1.0 & 0.9 & 1.1 & 1.1 & 1.5 & 0.5 & 6 \\
\hline 个 & & & & & 0.9 & 0.9 & 0.9 & 1.0 & 1.2 & 1.4 & 1.1 & 6 \\
\hline$\uparrow$ & & & & & 0.9 & 0.9 & 0.9 & 1.1 & 1.3 & 1.6 & 1.0 & 6 \\
\hline$\uparrow$ & & & & & 0.9 & 0.9 & 1.0 & 1.2 & 1.4 & 1.6 & 1.0 & 6 \\
\hline & & & & & 0.8 & 0.8 & 0.9 & 1.0 & 1.1 & 1.5 & 0.9 & 6 \\
\hline$\uparrow$ & & & & & 1.0 & 0.9 & 1.1 & 1.0 & 1.2 & 1.4 & 1.0 & 6 \\
\hline & & & & & 1.0 & 1.2 & 1.0 & 1.3 & 1.2 & 1.5 & 1.2 & 6 \\
\hline & 0.6 & 0.9 & 1.2 & 1 & 0.8 & 1.4 & 1.0 & 1.1 & 1.1 & 1.6 & 1.0 & 6 \\
\hline & 1.0 & 1.9 & 1.1 & 3 & 1.1 & 1.0 & 0.7 & 0.5 & 0.5 & 0.8 & 0.8 & 2 \\
\hline & 1.0 & 0.9 & 0.7 & 4 & & & & & & & & \\
\hline & & & 0.2 & & & & & & & & & \\
\hline & & & 0.3 & & & & & & & & & \\
\hline
\end{tabular}




\begin{tabular}{|c|c|}
\hline BeG30N07B05 & No match \\
\hline BeG30N07H04 & No match \\
\hline BeG30N09F11 & No match \\
\hline BeG30N19F01 & No match \\
\hline BeG3ON2OH01 & No match \\
\hline BeG60N02F02 & No match \\
\hline BeG90N08C07 & No match \\
\hline BeG90N14F04 & No match \\
\hline BeG90N16D10 & No match \\
\hline BeG90N18G05 & No match \\
\hline BeG90N19C11 & No match \\
\hline BeNSVP12G03 & No match \\
\hline BeZSPN07G06 & No match \\
\hline BeZSPN08H06 & No match \\
\hline BeZSPN10G04 & No match \\
\hline BeZSPN15B11 & No match \\
\hline BeE120N04F05 & No match \\
\hline BeE120N10B07 & No match \\
\hline BeE120N10F10 & No match \\
\hline BeE120N18H10 & No match \\
\hline BeE120N25G04 & No match \\
\hline BeE120N29D03 & No match \\
\hline BeE120N37H11 & No match \\
\hline BeE30N01E07 & No match \\
\hline BeE30N21A09 & No match \\
\hline BeE60C10F08 & No match \\
\hline BeE60C13E11 & No match \\
\hline BeE60C23B10 & No match \\
\hline BeE60C26D02 & No match \\
\hline $\mathrm{BeE} 60 \mathrm{H} 04 \mathrm{C} 08$ & No match \\
\hline BeE60H05B11 & No match \\
\hline BeE60H09C02 & No match \\
\hline BeE60H26C07 & No match \\
\hline BeE60N09C07 & No match \\
\hline BeE60N13D02 & No match \\
\hline BeE60N17G08 & No match \\
\hline BeE60N19H04 & no match \\
\hline BeE90D09G06 & No match \\
\hline BeE90N05E03-1 & No match \\
\hline BeE90N14F08 & No match \\
\hline BeG120N16F11 & No match \\
\hline BeG120N22H04 & No match \\
\hline BeG30N05D01 & No match \\
\hline BeG30N09B10 & No match \\
\hline BeG30N09G04 & No match \\
\hline BeG30N15G07 & No match \\
\hline BeG60N17B11 & No match \\
\hline BeG90N01C12 & No match \\
\hline BeG90N10F08 & No match \\
\hline BeZSPN04B05 & No match \\
\hline BeZSPN04C11 & No match \\
\hline BeZSPN15F04 & No match \\
\hline
\end{tabular}

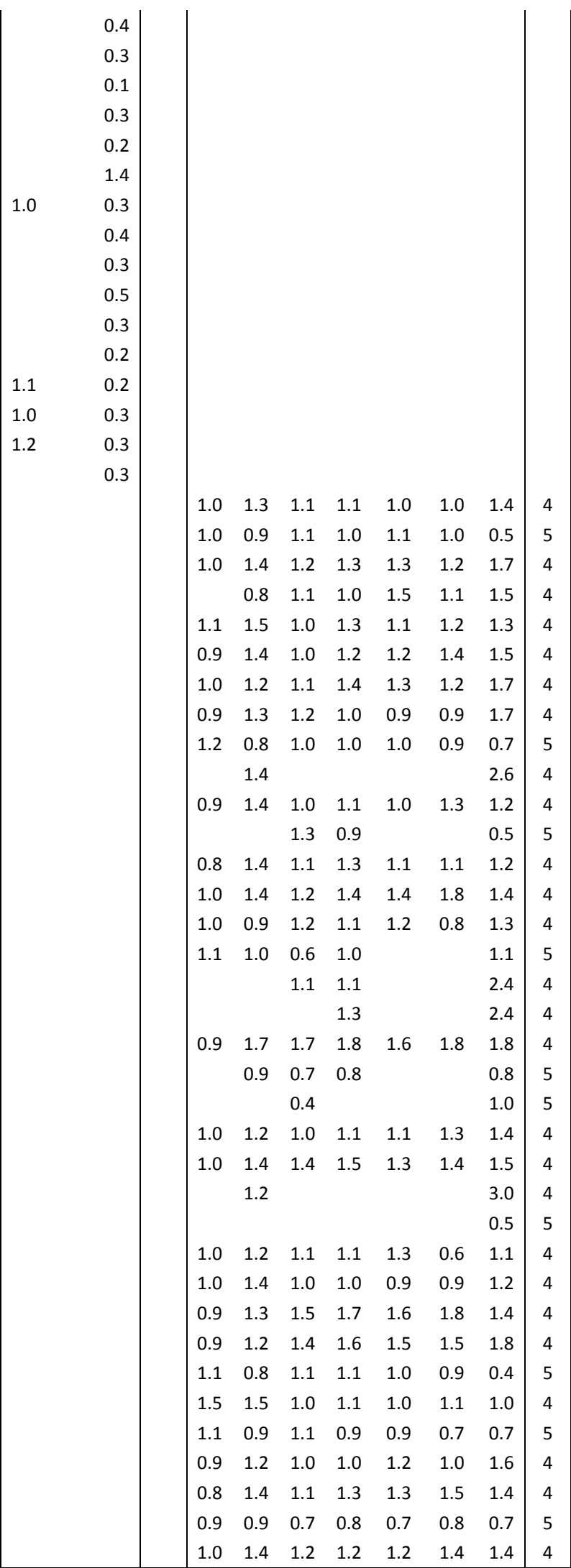


Tabela S 2: Lista completa dos genes diferencialmente expressos por carência de ferro (II) e comparação com os microarranjos de hipóxia gradual e direta. Os valores representam a razão de expressão (teste/C70). As setas indicam os perfis de indução (para cima) ou repressão (para baixo).

\begin{tabular}{|c|c|c|c|c|c|c|c|c|c|c|c|c|c|c|c|c|}
\hline \multirow[b]{2}{*}{ Clone ID } & \multirow[b]{2}{*}{ SwissProt } & \multirow[b]{2}{*}{ Anotação } & \multirow{2}{*}{ 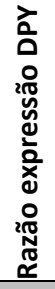 } & \multirow{2}{*}{ 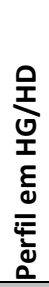 } & \multicolumn{4}{|c|}{ Hipóxia Direta } & \multicolumn{8}{|c|}{ Hipóxia Gradual } \\
\hline & & & & & 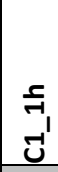 & 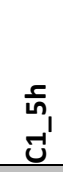 & 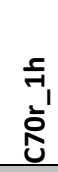 & 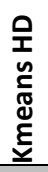 & $\stackrel{0}{0}$ & $\stackrel{n}{\dddot{Y}}$ & $\stackrel{\text { ñ }}{\check{c}}$ & 气 & 더 & 8 & ডั & 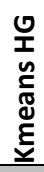 \\
\hline \multicolumn{17}{|c|}{ Metabolismo de Aminoácidos } \\
\hline BeG90N11B07 & & acetolactate synthase Ilv2 [Filobasidiella neoform & 0.3 & & & & & & & & & & & & & \\
\hline BeG30N08D01 & Q9Y3D8 & Adenylate kinase isoenzyme 6 & 0.5 & $\downarrow$ & 0.9 & 0.6 & 0.9 & 4 & 1.0 & 1.0 & 1.0 & 0.9 & 0.6 & 0.6 & 1.1 & 2 \\
\hline BeG60N02D07 & & glycine cleavage system $\mathrm{H}$ protein (16.0 kD) & 0.5 & & & & & & 1.0 & 1.0 & 0.8 & 1.0 & 1.0 & 1.0 & 0.6 & 5 \\
\hline BeE60N17D10 & & asparagiNyl tRNA Synthetase NRS-1 (61.2 kD) (nrs-1 & 0.6 & & & & & & & & & & & & & \\
\hline $\mathrm{BeE} 60 \mathrm{H} 21 \mathrm{G} 01$ & & homogentisate 1,2-dioxygenase & 0.6 & & & & & & 1.0 & 1.4 & 1.2 & 1.3 & 0.9 & 1.0 & 0.9 & 4 \\
\hline BeE60H28B12 & Q96VZ6 & Acetolactate synthase Ilv2 & 0.6 & $\downarrow$ & 0.4 & 0.5 & 2.9 & 1 & 1.0 & 1.2 & 1.5 & 1.3 & 0.3 & 0.3 & 1.5 & 1 \\
\hline BeE30N02B01 & 004974 & 2-isopropylmalate synthase B & 0.6 & & & & & & & & & & & & & \\
\hline \multicolumn{17}{|c|}{ Ciclo Celular } \\
\hline BeE120N28B12 & Q9C1M3 & Septin & 0.6 & & & & & & & & & & & & & \\
\hline $\mathrm{BeE} 60 \mathrm{H} 26 \mathrm{CO} 8$ & Q9P3A7 & Cell division cycle protein 48 homolog & 1.7 & & & & & & 1.0 & 0.9 & 0.9 & 1.1 & 0.9 & 1.0 & 0.7 & 5 \\
\hline \multicolumn{17}{|c|}{ Estrutura de Cromatina } \\
\hline BeG30N17G05 & Q1469 & programmed cell death 11 & 0.6 & $\downarrow$ & 0.9 & 0.7 & 0.9 & 4 & & & & & & & & \\
\hline \multicolumn{17}{|c|}{ Metabolismo Energético } \\
\hline BeE90D08B03 & & $\begin{array}{l}\text { glycogen storage control protein, putative } \\
\text { [Cryptococcus }\end{array}$ & 0.3 & & & & & & & & & & & & & \\
\hline BeE120N27B02 & P56205 & Cytochrome c & 0.3 & $\downarrow$ & 0.6 & 0.7 & 1.0 & 1 & 1.0 & 0.9 & 0.9 & 0.9 & 0.5 & 0.3 & 1.4 & 1 \\
\hline BeG120N23E11 & Q99L23 & NADH dehydrogenase (Fragment) & 0.3 & & & & & & & & & & & & & \\
\hline BeG120N07H08 & 074699 & Aconitase & 0.4 & $\downarrow$ & & & & & 1.0 & 0.9 & 0.8 & 0.9 & 1.0 & 0.8 & 1.4 & 2 \\
\hline BeE120N27B03 & Q03015 & $\mathrm{NADH}$-ubiquinone oxidoreductase $12 \mathrm{kDa}$ subunit & 0.5 & $\downarrow$ & & & & & 1.1 & 0.8 & 0.9 & 0.9 & 0.8 & 0.7 & 1.0 & 2 \\
\hline BeZSPN09F10 & Q8J267 & Aconitase (Fragment) & 0.5 & & & & & & & & & & & & & \\
\hline BeE120N08B02 & & aconitase 2, mitochondrial [Danio rerio] & 0.5 & & & & & & & & & & & & & \\
\hline BeE120N20G02 & 097725 & NADH-ubiquinone oxidoreductase subunit B17. & 0.6 & & & & & & & & & & & & & \\
\hline BeG30N12E07 & Q9P8D2 & Cytochrome c oxidase subunit $\mathrm{V}$ & 0.6 & $\uparrow$ & 1.4 & 1.2 & 0.9 & 5 & & & & & & & & \\
\hline BeE120N37A09 & Q7SGS6 & $\begin{array}{l}\text { succinate dehydrogenase flavoprotein subunit } \\
\text { precursor }\end{array}$ & 0.6 & & & & & & & & & & & & & \\
\hline BeG90N12C05 & & glutaryl-Coenzyme A dehydrogenase isoform a & 0.6 & $\downarrow$ & & & & & 1.0 & 1.0 & 0.9 & 0.7 & 0.6 & 0.4 & 0.9 & 2 \\
\hline $\mathrm{BeG} 30 \mathrm{~N} 06 \mathrm{H} 08$ & & Isocitrate lyase (Isocitrase) (Isocitratase) (ICL) & 0.6 & & & & & & & & & & & & & \\
\hline BeG90N18D03 & & Similar to cytochrome c-1 [Xenopus laevis] & 0.7 & & & & & & & & & & & & & \\
\hline BeG120N10C03 & & NADH-ubiquinone oxidoreductase $30.4 \mathrm{kDa}$ subunit, $\mathrm{p}$ & 0.7 & & & & & & & & & & & & & \\
\hline BeE120N01B06 & P17568 & NADH-ubiquinone oxidoreductase B18 subunit & 0.7 & & & & & & & & & & & & & \\
\hline BeE120N01B08 & & $\mathrm{NADH}$-ubiquinone oxidoreductase $51 \mathrm{kDa}$ subunit, put & 0.7 & & & & & & & & & & & & & \\
\hline BeG60N09E05 & P52504 & NADH-ubiquinone oxidoreductase $13 \mathrm{kDa}-\mathrm{A}$ sub & 0.7 & & & & & & & & & & & & & \\
\hline $\mathrm{BeE60H08E04}$ & Q9A212 & Quinone oxidoreductase & 1.6 & $\uparrow$ & 1.2 & 1.5 & 1.0 & 3 & & & & & & & & \\
\hline BeE60N10B03 & & vacuolar ATP synthase subunit c" & 1.6 & $\uparrow$ & 2.1 & 1.3 & 0.9 & 5 & 0.9 & 1.2 & 1.1 & 1.4 & 2.3 & 2.2 & 0.8 & 6 \\
\hline BeE30N03G09 & Q7PRL2 & V-type ATPase proteolipid subunit & 1.6 & & & & & & & & & & & & & \\
\hline BeE120N28B05 & P48826 & Glucose-6-phosphate 1-dehydrogenase & 1.6 & & & & & & & & & & & & & \\
\hline BeE60N05D05 & Q8EBH2 & Transaldolase & 1.8 & $\uparrow$ & 1.5 & 1.5 & 1.0 & 3 & 1.1 & 1.0 & 1.0 & 1.2 & 1.6 & 3.1 & 0.8 & 6 \\
\hline BeE30N04H06 & Q9Z2K9 & Isocitrate dehydrogenase [NADP] cytoplasmic & 1.8 & $\downarrow$ & & & & & 1.1 & 1.3 & 1.2 & 1.1 & 0.6 & 0.8 & 1.0 & 2 \\
\hline BeE60N18F02 & P48826 & Glucose-6-phosphate 1-dehydrogenase & 1.8 & & & & & & & & & & & & & \\
\hline BeE30N21H07 & P06738 & Glycogen phosphorylase & 2.0 & $\uparrow$ & 1.3 & 2.0 & 1.0 & 3 & 1.1 & 1.1 & 0.9 & 1.2 & 1.4 & 1.7 & 0.7 & 6 \\
\hline BeG90N11A02 & Q90WD9 & Glyceraldehyde 3-phosphate dehydrogenase & 2.2 & $\uparrow$ & 1.9 & 2.4 & 1.2 & 3 & 1.0 & 1.4 & 1.3 & 2.0 & 2.3 & 2.6 & 0.9 & 7 \\
\hline \multicolumn{17}{|c|}{ Metabolismo de Lipídeos } \\
\hline BeE90D17G07 & Q9P4D7 & $\begin{array}{l}\text { Long chain polyunsaturated fatty acid elongation } \\
\text { enzyme }\end{array}$ & 1.4 & & 0.6 & 1.0 & 0.8 & 1 & 1.0 & 1.0 & 1.1 & 1.4 & 1.2 & 1.3 & 0.6 & 6 \\
\hline $\mathrm{BeE} 60 \mathrm{H} 26 \mathrm{A05}$ & Q872A4 & Related to phosphatidylserine decarboxylase & 1.7 & $\uparrow$ & 5.0 & 2.6 & 1.0 & 6 & 0.9 & 1.8 & 2.5 & 6.1 & \#\#\#\# & \#\#\#\# & 2.7 & 7 \\
\hline BeG90N07B07 & Q7Q192 & leukotriene $\mathrm{A} 4$ hydrolase & 1.7 & $\uparrow$ & 1.6 & 1.1 & 0.7 & 5 & & & & & & & & \\
\hline
\end{tabular}




\begin{tabular}{|c|c|c|c|c|c|c|c|c|c|c|c|c|c|c|c|c|}
\hline $\begin{array}{l}\text { BeE60N03G10 } \\
\text { BeZSPN11E04 } \\
\text { BeZSPN15E12 }\end{array}$ & Q7SBV0 & $\begin{array}{l}\text { cyclopropane-fatty-acyl-phospholipid synthase } \\
\text { deoxyhypusine hydroxylase } \\
\text { deoxyhypusine hydroxylase/monooxygenase }\end{array}$ & $\begin{array}{l}1.9 \\
2.5 \\
3.4\end{array}$ & $\uparrow$ & & & & & 1.1 & 1.8 & 1.5 & 3.8 & 8.9 & 5.7 & 2.0 & 7 \\
\hline \multicolumn{17}{|c|}{ Metabolismo de Ácidos Nucleicos } \\
\hline BeE90D15C05 & 094413 & Ribose-phosphate pyrophosphokinase & 0.5 & $\uparrow$ & 1.9 & 1.7 & 1.3 & 3 & 1.1 & 0.9 & 0.9 & 0.9 & 1.4 & 1.7 & 0.9 & 6 \\
\hline BeG30N12D07 & 093937 & PyrABCN & 0.5 & $\downarrow$ & 0.7 & 1.2 & 2.0 & 1 & 1.0 & 0.7 & 0.4 & 0.7 & 0.6 & 0.8 & 0.9 & 2 \\
\hline BeG30N04E02 & P50094 & Probable inosine-5'-monophosphate dehydroge & 0.6 & & & & & & & & & & & & & \\
\hline BeZSPN03F10 & & probable inosine-5\'-monophosphate dehydrogenase & 0.6 & $\uparrow$ & 1.1 & 1.5 & 1.4 & 3 & & & & & & & & \\
\hline \multicolumn{17}{|c|}{ Enovelamento e Modificação de Proteínas } \\
\hline BeE120N06B11 & Q8CEE6 & PAS domain containing serine/threonine kinase & 0.3 & & & & & & & & & & & & & \\
\hline BeG30N13C06 & & Ribosomal RNA processing protein 28 & 0.5 & $\downarrow$ & & & & & 0.9 & 1.1 & & 0.9 & & 0.6 & 1.0 & 2 \\
\hline BeE30N18D09 & Q8UGX7 & Peptide methionine sulfoxide reductase $\mathrm{msrB}$ & 0.6 & & & & & & & & & & & & & \\
\hline BeE30N03D10 & P25007 & Peptidyl-prolyl cis-trans isomerase & 1.4 & & & & & & & & & & & & & \\
\hline BeE30N21E09 & Q7ZWL1 & Similar to prolyl endopeptidase (Fragment) & 1.4 & & & & & & & & & & & & & \\
\hline $\mathrm{BeE60H} 28 \mathrm{G} 06$ & 073817 & Proteasome subunit beta type 3 & 1.5 & & & & & & & & & & & & & \\
\hline BeE60H23C11 & Q9W227 & similar to peptidylprolyl isomerase B isoform 1 & 1.5 & & & & & & & & & & & & & \\
\hline BeE60N10D10 & & proteasome subunit alpha type- 4 & 1.5 & & & & & & & & & & & & & \\
\hline BeG120N08G03 & Q13200 & $26 \mathrm{~S}$ proteasome non-ATPase regulatory subuni & 1.5 & & & & & & & & & & & & & \\
\hline BeE60N15G05 & & DnaJ-like protein MsJ1 - alfalfa & 1.6 & $\uparrow$ & 1.6 & 1.2 & 1.0 & 5 & 1.1 & 1.1 & 1.3 & 1.4 & 2.4 & 2.7 & 0.8 & 7 \\
\hline BeE60N13G06 & Q96U28 & Probable 26s proteasome $\mathrm{p} 44.5$ protein & 1.7 & & & & & & & & & & & & & \\
\hline BeG30N09H07 & P52493 & Ubiquitin-conjugating enzyme E2-17 kDa & 1.8 & & & & & & & & & & & & & \\
\hline BeE60H17C06 & P52495 & Ubiquitin-activating enzyme E1 1 (Fragment) & 1.8 & $\uparrow$ & & & & & 1.0 & 1.1 & 1.1 & 1.4 & 1.1 & 1.1 & 0.7 & 6 \\
\hline BeE90D05G05 & Q7Z8F2 & Putative serine/threonine phosphatase $2 \mathrm{C}$ ptc2 & 1.8 & $\uparrow$ & 2.3 & 1.9 & 0.9 & 5 & 1.0 & 1.3 & 1.5 & 2.2 & 4.9 & 4.8 & 0.9 & 7 \\
\hline BeZSPN13B02 & Q9HF04 & Vacuolar serine protease & 1.9 & & & & & & & & & & & & & \\
\hline BeG90N22C02 & Q9PTW9 & Proteasome subunit alpha type 7 & 1.9 & & & & & & & & & & & & & \\
\hline BeE60N14C07 & 014413 & Proteinase A & 2.2 & & & & & & & & & & & & & \\
\hline \multicolumn{17}{|c|}{ Homeostase Redox } \\
\hline BeE60N14F11 & Q9BGI3 & Peroxiredoxin 2 & 1.3 & $\uparrow$ & & & & & 0.7 & 1.1 & 1.2 & 1.3 & 1.3 & 1.3 & 1.1 & 6 \\
\hline BeE90D16C06 & P91252 & Probable glutathione S-transferase 6 & 1.4 & & & & & & & & & & & & & \\
\hline BeE60C04G01 & 014463 & Thioredoxin & 1.5 & & & & & & & & & & & & & \\
\hline BeE60C31E12 & Q94GY8 & Putative glutathione S-transferase & 2.0 & & & & & & & & & & & & & \\
\hline BeE120N37A02 & Q94GY8 & Putative glutathione S-transferase & 2.1 & & & & & & & & & & & & & \\
\hline $\mathrm{BeE} 60 \mathrm{H} 11 \mathrm{CO} 4$ & Q7YXM3 & peroxiredoxins [Phanerochaete chrysosporium] & 3.2 & & & & & & & & & & & & & \\
\hline BeE60C19G01 & & Thioredoxin peroxidase & 3.4 & $\downarrow$ & 0.6 & 1.1 & 1.0 & 1 & & & & & & & & \\
\hline \multicolumn{17}{|c|}{ Proteínas Ribossomais / Tradução } \\
\hline BeG60N15D01 & 07469 & SNU13 snRNP subunit homolog & 0.3 & $\downarrow$ & 0.6 & 0.5 & 0.9 & 1 & 1.0 & 0.9 & 0.9 & 0.8 & 0.4 & 0.2 & 1.2 & 1 \\
\hline BeG90N10A10 & P32495 & High mobility group & 0.4 & $\downarrow$ & & 0.5 & 0.9 & & 1.0 & 1.0 & 0.9 & 0.9 & 0.5 & 0.4 & 1.2 & 2 \\
\hline BeG120N20E02 & Q9NPE3 & H/ACA ribonucleoprotein complex subunit 3 & 0.4 & $\downarrow$ & 0.4 & 0.4 & 0.9 & 2 & 0.9 & 0.9 & 1.1 & 0.9 & 0.3 & 0.3 & 1.3 & 2 \\
\hline BeG120N02A10 & Q09916 & Putative ATP dependent RNA helicase C1F7.02 & 0.4 & $\downarrow$ & 0.6 & 0.6 & 0.9 & 1 & 1.0 & 1.0 & 0.9 & 0.9 & 0.4 & & 1.1 & 1 \\
\hline BeG120N22A08 & P38805 & Ribosome biogenesis protein RPF1 & 0.5 & & & & & & & & & & & & & \\
\hline BeG90N04A04 & & Probable eukaryotic translation initiation factor & 0.5 & $\downarrow$ & 0.6 & 0.7 & 1.1 & 1 & & & & & & & & \\
\hline BeZSPN17H02 & & similar to Fibrillarin CG9888PA & 0.6 & $\downarrow$ & & & & & 1.0 & 1.0 & 0.9 & 0.9 & 0.5 & 0.4 & 1.1 & 2 \\
\hline BeG90N19G08 & Q8S1Z1 & U3 small nucleolar RNA-associated & 0.6 & & & & & & & & & & & & & \\
\hline BeG120N04E02 & & $\begin{array}{l}\text { Homo sapiens eukaryotic translation initiation factor } \\
1 \mathrm{~A}\end{array}$ & 0.7 & $\downarrow$ & & & & & 0.9 & 0.9 & 0.9 & 0.8 & 0.7 & 0.6 & 1.0 & 2 \\
\hline BeE90N16A07 & Q7MXM0 & Aspartyl-tRNA synthetase & 1.8 & & & & & & & & & & & & & \\
\hline BeE90D07H12 & P25444 & $40 S$ ribosomal protein $\mathrm{S} 2$ & 1.8 & & & & & & & & & & & & & \\
\hline \multicolumn{17}{|c|}{ Transdução de Sinal } \\
\hline BeE90D03C08 & Q8BWJ3 & $\begin{array}{l}\text { Phosphorylase B kinase alpha regulatory chain, liver } \\
\text { isoform }\end{array}$ & 0.7 & & & & & & & & & & & & & \\
\hline BeZSPN16D09 & Q12741 & cAMP-dependent protein kinase catalytic sub & 1.4 & $\uparrow$ & 1.2 & 1.4 & 1.3 & 3 & & & & & & & & \\
\hline BeG90N08A02 & Q9W7I1 & activated protein kinase $\mathrm{C}$ receptor & 1.5 & $\uparrow$ & 0.9 & 1.4 & 1.1 & 3 & & & & & & & & \\
\hline \multicolumn{17}{|c|}{ Resposta a Estresse } \\
\hline BeG60N07C03 & Q9S9N1 & Hsp70-3 (Blastocladiella emersonii) & 0.7 & $\downarrow$ & & & & & 1.1 & 1.0 & 0.8 & 0.8 & 0.6 & 0.7 & 1.0 & 2 \\
\hline BeE60H30A07 & Q818Z4 & Heat shock protein 90 (Fragment) & 1.6 & & & & & & & & & & & & & \\
\hline \multicolumn{17}{|c|}{ Estrutura Celular / Microtúbulos } \\
\hline BeE90N19F03 & Q8WXX0 & Ciliary dynein heavy chain 7 & 0.5 & & & & & & & & & & & & & \\
\hline BeE60N10H11 & & kinesin heavy chain & 0.6 & & & & & & & & & & & & & \\
\hline \multicolumn{17}{|c|}{ Transcrição / Processamento de RNA } \\
\hline BeG90N10B01 & & DNA-directed RNA polymerase I subunit D protein & 0.5 & $\downarrow$ & 0.6 & 0.6 & 1.0 & 1 & 0.9 & 1.0 & 0.9 & 0.9 & 0.5 & 0.5 & 1.3 & 2 \\
\hline BeE30N22H05 & 081098 & RNA polymerase I, II and III 24.3 kDa subun & 0.6 & $\downarrow$ & 0.2 & 0.7 & 1.0 & 2 & & & & & & & & \\
\hline BeE90D08E03 & P34253 & RNA polymerase II elongator-associated protein & 1.9 & $\uparrow$ & 2.1 & 1.7 & 0.9 & 5 & 1.0 & 1.2 & 1.5 & 2.0 & 3.9 & 4.5 & 0.9 & 7 \\
\hline
\end{tabular}




\begin{tabular}{|c|c|c|c|c|c|c|c|c|c|c|c|c|c|c|c|c|}
\hline & & Transporte & & & & & & & & & & & & & & \\
\hline BeG60N20F09 & Q87216 & Probable iron inhibited $A B C$ transporter $2 \mathrm{G}$ & 0.4 & $\downarrow$ & 0.7 & 0.7 & 1.0 & 1 & 1.0 & 1.0 & 1.1 & 1.0 & 0.7 & 0.7 & 1.4 & 2 \\
\hline BeZSPN05F06 & & hypothetical protein [Neurospora crassa] & 0.5 & $\downarrow$ & & & & & 1.0 & 1.0 & 1.0 & 0.9 & 0.7 & 0.8 & 1.5 & 2 \\
\hline BeE60C03A02 & & Cation/multidrug efflux pump [Pseudomonas & 0.6 & & & & & & & & & & & & & \\
\hline BeE60N18C10 & & Acyl carrier protein, mitochondrial precursor (ACP & 0.6 & & & & & & & & & & & & & \\
\hline BeE60N18A11 & & $\begin{array}{l}\text { putative phosphate/phosphoenolpyruvate } \\
\text { translocator }\end{array}$ & 0.7 & $\downarrow$ & & & & & 1.0 & 1.0 & 0.9 & 1.0 & 0.8 & 0.6 & 0.8 & 2 \\
\hline BeNSVP07B10 & & proton glutamate symport protein & 1.4 & $\uparrow$ & 0.9 & 1.6 & 1.0 & 3 & 0.8 & 0.8 & 1.0 & 1.2 & 1.4 & 1.8 & 1.0 & 6 \\
\hline BeG60N01F09 & & methionine permease, putative [Neosartorya fischeri & 1.8 & $\uparrow$ & 1.6 & 2.1 & 0.9 & 3 & & & & & & & & \\
\hline BeE60N12D06 & Q9JL62 & Glycolipid transfer protein & 2.0 & $\uparrow$ & 2.3 & 1.7 & 1.1 & 5 & 1.0 & 1.3 & 1.3 & 1.9 & 2.8 & 2.8 & 1.0 & 7 \\
\hline BeG30N13H08 & Q9JL97 & GPI-anchored ceruloplasmin & 2.5 & & & & & & 1.1 & 1.0 & 1.1 & 0.8 & 0.6 & & 0.7 & 5 \\
\hline BeZSPN15C05 & & high-affinity iron permease [Rhizopus oryzae] & 2.7 & $\downarrow$ & & & & & & 0.9 & & 0.8 & & 0.6 & 0.5 & 2 \\
\hline BeG90N02G07 & Q8JZT2 & S-adenosylmethionine mitochondrial carrier protein & 2.7 & & & & & & & & & & & & & \\
\hline BeG30N20G10 & & $\mathrm{ABC}$ transporter-like protein [Arabidopsis thaliana & 3.3 & & & & & & & & & & & & & \\
\hline BeG120N25D02 & Q92341 & siderophore iron transporter mirC & 4.9 & & & & & & & & & & & & & \\
\hline BeG30N19E11 & & zinc/iron permease & 8.9 & & & & & & 1.0 & 1.6 & 1.1 & 0.5 & 0.6 & 1.0 & 0.6 & 5 \\
\hline & & Outros & & & & & & & & & & & & & & \\
\hline BeE90N06H03 & Q81CV0 & Hydrolase & 0.2 & $\downarrow$ & & 0.1 & & & & 0.4 & 0.7 & 0.2 & & 0.3 & 1.2 & 8 \\
\hline BeE60C18D04 & Q8FW89 & Quinone oxidoreductase & 0.2 & & & & & & & & & & & & & \\
\hline BeNSVP04C06 & P19727 & Minor capsid protein $10 \mathrm{~B}$ & 0.3 & & & & & & & & & & & & & \\
\hline BeG30N08D09 & Q92R40 & Hypothetical protein & 0.3 & & & & & & & & & & & & & \\
\hline BeG30N20D08 & Q9UUG1 & Brix domain containing protein 1 homolog & 0.3 & $\downarrow$ & 0.5 & 0.7 & 1.0 & 1 & 0.9 & 1.2 & 0.9 & 0.9 & & 0.4 & 1.2 & 1 \\
\hline BeG60N08E04 & 042468 & PP2A inhibitor & 0.4 & $\downarrow$ & 0.5 & 0.6 & 1.0 & 1 & 1.0 & 1.1 & 0.7 & 0.8 & 0.3 & 0.3 & 1.2 & 1 \\
\hline BeE60C21A11 & Q88FF9 & Outer membrane siderophore receptor & 0.4 & & & & & & & & & & & & & \\
\hline BeG60N12C05 & Q9BQ67 & Glutamate-rich WD-repeat protein 1 & 0.5 & & & & & & & & & & & & & \\
\hline BeG60N12C04 & P53738 & Hypothetical 15.1 kDa protein in PET494MSO & 0.5 & $\downarrow$ & & & & & 0.8 & 1.1 & 1.0 & 1.1 & 0.7 & 0.3 & 1.4 & 1 \\
\hline BeG90N07D08 & Q8EIN1 & Alkaline phosphatase, putative & 0.5 & & & & & & & & & & & & & \\
\hline BeE30N07B04 & P53326 & Hypothetical 81.2 kDa protein in MES1-FOL2 & 0.6 & $\uparrow$ & 1.7 & 1.4 & 0.9 & 5 & 1.0 & 1.0 & 1.2 & 1.7 & 2.4 & 2.8 & 1.4 & 7 \\
\hline BeE60C15B06 & & Fe2+-dicitrate sensor & 0.6 & $\downarrow$ & 0.3 & 0.9 & 0.8 & 2 & & & & & & & & \\
\hline BeZSPN14H05 & & histidinol phosphate aminotransferase & 0.6 & $\downarrow$ & 0.7 & 1.0 & 1.4 & 1 & 1.0 & 0.7 & 0.7 & 0.7 & 0.3 & 0.2 & 0.7 & 1 \\
\hline BeE90D02B04 & P25338 & $\begin{array}{l}\text { Hypothetical } 20.2 \text { kDa protein in PRS2-LEU1 intergenic } \\
\text { region }\end{array}$ & 0.6 & & & & & & & & & & & & & \\
\hline BeE60C25F11 & & hypothetical protein & 0.6 & $\downarrow$ & & 0.5 & 1.2 & & & & & & & & & \\
\hline BeG120N18B05 & & hypothetical protein [Entamoeba histolyt & 0.6 & & & & & & & & & & & & & \\
\hline BeG30N15E09 & & hypothetical protein & 0.7 & & & & & & & & & & & & & \\
\hline BeE60N16C10 & & fiber protein Fb27 [Gossypium barbadense] & 0.7 & $\downarrow$ & 0.1 & 0.9 & 0.9 & 2 & & & & & & & & \\
\hline $\mathrm{BeG} 30 \mathrm{~N} 10 \mathrm{H} 02$ & & zinc finger, HIT type 6 & 0.7 & & & & & & & & & & & & & \\
\hline BeE60C05B10 & Q882A7 & Oxidoreductase, Gfo/Idh/MocA family & 0.7 & $\downarrow$ & 0.5 & 0.7 & 0.9 & 1 & & & & & & & & \\
\hline $\mathrm{BeG} 30 \mathrm{~N} 18 \mathrm{H} 02$ & 014236 & gtp-binding protein associated & 0.7 & & & & & & & & & & & & & \\
\hline BeE60C06H06 & Q7WWT9 & Putative NagM-like protein & 0.7 & $\downarrow$ & 0.7 & 0.7 & 0.8 & 4 & & & & & & & & \\
\hline BeG60N03C11 & & Hypothetical protein & 0.7 & & & & & & & & & & & & & \\
\hline BeG120N02B04 & P32469 & Diphthine synthase & 0.7 & $\downarrow$ & 0.5 & 0.5 & 0.9 & 1 & 1.0 & 1.0 & 0.8 & 0.9 & 0.5 & 0.4 & 1.1 & 1 \\
\hline BeE90N11H01 & & hypothetical protein & 0.7 & & & & & & & & & & & & & \\
\hline BeZSPN12D07 & Q7SH92 & Hypothetical protein & 1.4 & & & & & & & & & & & & & \\
\hline BeZSPN16B05 & Q9NY68 & Hypothetical protein & 1.5 & & & & & & & & & & & & & \\
\hline BeG120N23D09 & & putative protein disulfate isomerase & 1.5 & $\uparrow$ & 1.5 & 1.8 & 1.1 & 3 & 1.0 & 1.2 & 1.2 & 1.5 & 1.9 & 1.6 & 0.8 & 6 \\
\hline BeNSVP06B04 & & Hypothetical protein & 1.7 & $\uparrow$ & & 2.3 & 1.2 & & & & & & & & & \\
\hline & & No Match & & & & & & & & & & & & & & \\
\hline BeE60N06F03 & & No match & 0.0 & & & & 0.2 & & & & & & & & & \\
\hline BeZSPN18D04 & & No match & 0.1 & $\downarrow$ & 0.2 & 0.1 & & & & & & & & & & \\
\hline BeE120N28D05 & & No match & 0.1 & $\downarrow$ & & 0.2 & 0.2 & 7 & & & & & & & & \\
\hline BeG90N22E03 & & No match & 0.1 & & & & & & & & & & & & & \\
\hline BeE60C03D07 & & No match & 0.1 & $\downarrow$ & & & & & 1.1 & 0.5 & 0.7 & 0.4 & 0.9 & 0.4 & 1.2 & 2 \\
\hline BeNSVP12C06 & & No match & 0.2 & $\uparrow$ & & & & & 1.0 & 1.1 & 1.1 & 1.1 & 1.3 & 1.2 & 1.0 & 6 \\
\hline BeG90N18A04 & & No match & 0.3 & & & & & & & & & & & & & \\
\hline BeE120N02E01 & & No match & 0.4 & $\downarrow$ & 0.6 & 0.8 & 0.8 & 1 & & & & & & & & \\
\hline BeG90N19A08 & & No match & 0.4 & $\downarrow$ & 0.4 & 0.6 & 0.8 & 2 & & & & & & & & \\
\hline BeG60N18C02 & & No match & 0.4 & $\downarrow$ & 0.6 & 0.7 & 1.1 & 1 & 0.9 & 1.0 & 1.1 & 1.0 & 0.4 & 0.5 & 1.2 & 1 \\
\hline BeE60N15C03 & & No match & 0.4 & & & & & & & & & & & & & \\
\hline BeG60N14B04 & & No match & 0.4 & $\downarrow$ & & & & & 0.9 & 1.0 & 1.0 & 0.8 & 0.7 & 0.6 & 1.0 & 2 \\
\hline BeG60N07A06 & & No match & 0.4 & & & & & & & & & & & & & \\
\hline BeE60N04D07 & & No match & 0.4 & $\downarrow$ & & & & & 0.9 & 0.9 & 0.8 & 1.0 & 0.7 & 0.7 & 0.8 & 2 \\
\hline
\end{tabular}




\begin{tabular}{|c|c|}
\hline BeG60N07A03 & No match \\
\hline BeE60C28C01 & No match \\
\hline BeE90D02E01 & No match \\
\hline BeE60C25A12 & No match \\
\hline BeE60N13G01 & No match \\
\hline BeG60N04H08 & No match \\
\hline BeNSVP03B04 & No match \\
\hline BeE60C29F06 & No match \\
\hline BeG60N17D07 & No match \\
\hline BeNSVP09E01 & No match \\
\hline BeE60C08F10 & No match \\
\hline BeNSVP09H06 & No match \\
\hline BeE60H11C06 & No match \\
\hline BeE120N25H08 & No match \\
\hline BeE60C10C09 & No match \\
\hline BeE120N06D02 & No match \\
\hline BeG60N2OF04 & No match \\
\hline BeE90D11H09 & No match \\
\hline BeG30N10A03 & No match \\
\hline BeE90N18C02 & No match \\
\hline BeNSVP05B07 & No match \\
\hline BeE30N17F07 & No match \\
\hline BeE120N27B04 & No match \\
\hline BeE60C05A01 & No match \\
\hline BeE90D03E07 & No match \\
\hline BeE120N32B08 & No match \\
\hline BeE90D04A06 & No match \\
\hline BeE60N04D03 & No match \\
\hline BeE120N02C09 & No match \\
\hline BeE120N21E02 & No match \\
\hline BeZSPN10G09 & No match \\
\hline BeNSVP09C06 & No match \\
\hline BeG30N20G02 & No match \\
\hline BeE30N14E05 & No match \\
\hline BeE90D03F09 & No match \\
\hline BeE30N20G07 & No match \\
\hline BeG90N18G03 & No match \\
\hline BeE120NO2H03 & No match \\
\hline BeG30N08C10 & No match \\
\hline BeNSVP10H03 & No match \\
\hline BeG30N19F03 & No match \\
\hline BeZSPN06H07 & No match \\
\hline BeE60C29H10 & No match \\
\hline BeG30N10E11 & No match \\
\hline BeNSVP01G12 & No match \\
\hline BeG30N11D04 & No match \\
\hline BeG90N10C12 & No match \\
\hline BeG60N18G09 & No match \\
\hline BeE90D17B09 & No match \\
\hline BeE60N08A09 & No match \\
\hline BeZSPN03D11 & No match \\
\hline BeE12ON28H09 & No match \\
\hline BeE30N04H12 & No match \\
\hline BeE30N19C11 & No match \\
\hline BeE90D14C03 & No match \\
\hline BeNSVP02H10 & No match \\
\hline BeNSVP07F10 & No match \\
\hline BeE120N24A06 & No match \\
\hline BeG60N06H10 & No match \\
\hline BeE60H15D02 & No match \\
\hline BeE60N18B07 & No match \\
\hline BeE60N12F10 & No match \\
\hline
\end{tabular}

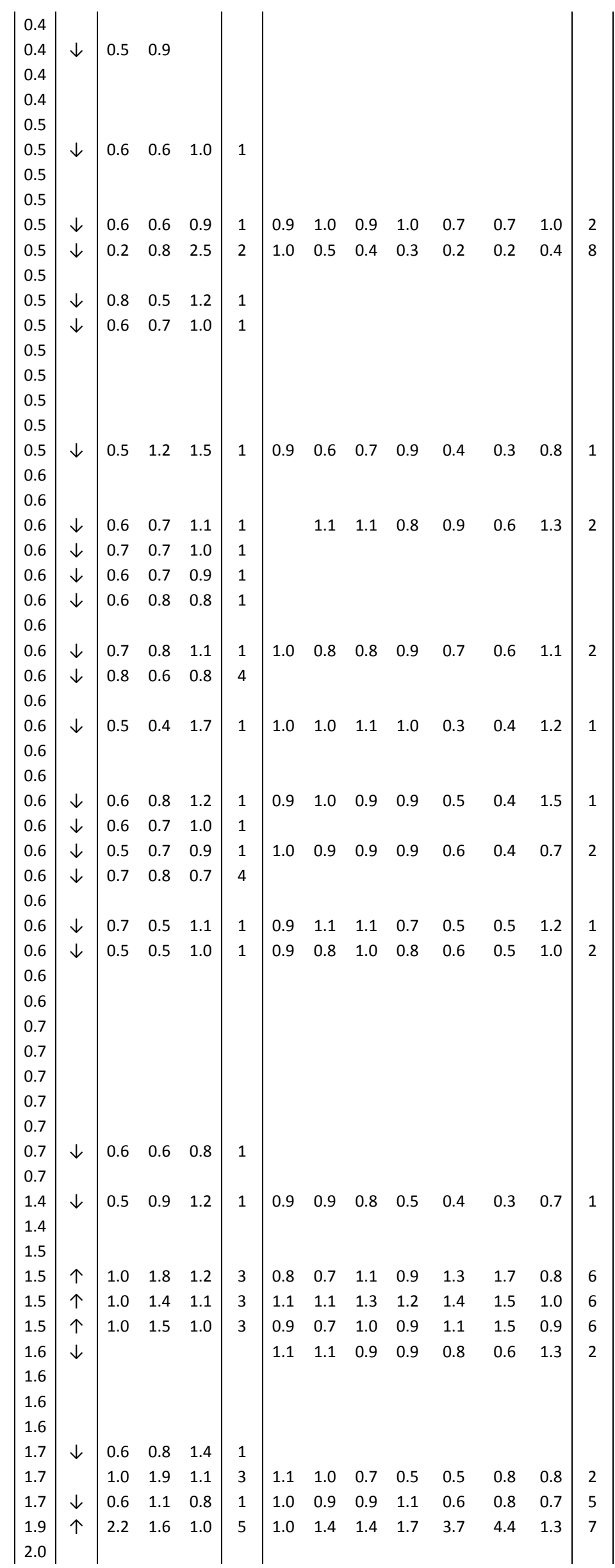




\begin{tabular}{|c|c|c|c|c|c|c|c|c|c|c|c|c|c|c|c|}
\hline BeE60H28C01 & No match & 2.1 & & & & & & & & & & & & & \\
\hline BeE120N38F02 & No match & 2.1 & & & & & & & & & & & & & \\
\hline BeE30N14F05 & No match & 2.3 & $\uparrow$ & 2.1 & 1.6 & 0.9 & 5 & 1.0 & 1.3 & 1.5 & 2.1 & 3.5 & 4.0 & 1.1 & 7 \\
\hline BeE30N20B08 & No match & 2.4 & $\uparrow$ & 1.7 & 1.7 & 1.0 & 3 & 1.0 & 1.3 & 1.5 & 2.4 & 2.4 & 3.2 & 1.1 & 7 \\
\hline BeG90N01C12 & No match & 3.3 & & & & & & 1.1 & 0.9 & 1.1 & 0.9 & 0.9 & 0.7 & 0.7 & 5 \\
\hline BeNSVP04A06 & No match & 3.6 & $\downarrow$ & 0.5 & 0.6 & 0.9 & 1 & 0.9 & 1.1 & 1.0 & 0.8 & 0.5 & 0.6 & 1.2 & 2 \\
\hline BeNSVP01A12 & No match & 3.8 & & & & & & & & & & & & & \\
\hline BeE60H26C07 & No match & 4.1 & & & & & & & & 1.1 & 1.1 & & & 2.4 & 4 \\
\hline BeE60H10F09 & No match & 6.9 & $\downarrow$ & 0.9 & 1.6 & 1.7 & 3 & & & & & & & & \\
\hline
\end{tabular}


Tabela S 3: Lista completa dos genes diferencialmente expressos no experimento de hipóxia + geldanamicina. Os valores são expressos em número de vezes reprimido. As setas indicam os perfis de expressão dos experimentos de hipóxia gradual e/ou direta (HG/HD) e no experimento de carência de ferro (II) (DPY).

\begin{tabular}{|c|c|c|c|c|c|}
\hline Clone ID & SwissProt & Anotação & 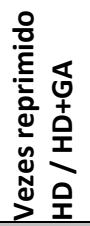 & 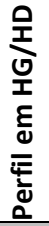 & 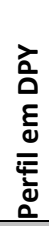 \\
\hline \multicolumn{6}{|c|}{ Metabolismo de Aminoácidos } \\
\hline BeG9N7G3 & & glutamate dehydrogenase, NAD(P)+ & -6.3 & & \\
\hline \multicolumn{6}{|c|}{ Reparo de DNA } \\
\hline BeG3N14F1 & & ATP-dependent DNA helicase pcra & -13.3 & & \\
\hline \multicolumn{6}{|c|}{ Metabolismo Energético } \\
\hline BeE6N5D5 & Q8EBH2 & Transaldolase & -1.6 & $\uparrow$ & $\uparrow$ \\
\hline BeG9N18E8 & Q8X97 & Probable ATP-citrate synthase subunit 1 & -1.7 & $\uparrow$ & \\
\hline BeE12N3E1 & Q8ZN3 & D-lactate dehydrogenase & -1.4 & $\uparrow$ & \\
\hline \multicolumn{6}{|c|}{ Metabolismo de Lipídeos } \\
\hline BeE6H26A5 & Q872A4 & Related to phosphatidylserine decarboxylase & -1.6 & $\uparrow$ & $\uparrow$ \\
\hline BeG6N6G5 & P7978 & Delta-9 fatty acid desaturase & -2.0 & $\uparrow$ & \\
\hline BeZSPN14C8 & & lysophospholipase [Ajellomyces & -6.9 & & \\
\hline BeG9N7B7 & & leukotriene A4 hydrolase & -1.5 & $\uparrow$ & $\uparrow$ \\
\hline BeG9N15A12 & & fatty acid elongase (Gig3) & -5.3 & & \\
\hline \multicolumn{6}{|c|}{ Metabolismo de Ácidos Nucleicos } \\
\hline BeG9N17F7 & & carbamoyl-phosphate synthase arginine-specific large chain & -19.6 & & $\downarrow$ \\
\hline \multicolumn{6}{|c|}{ Proteínas Ribossomais / Tradução } \\
\hline BeG12N16D6 & & mitochondrial S4 ribosomal protein [Saccharomyces & -11.8 & & \\
\hline BeE3N21H12 & 013418 & $6 \mathrm{~S}$ ribosomal protein $\mathrm{L} 15$ & -1.6 & & \\
\hline BeG9N11F1 & Q81SP7 & ribosomal protein L9 & -1.3 & & \\
\hline BeG3N2A1 & & similar to Ribosomal protein, large, P1 & -7.6 & & \\
\hline BeG12N6A4 & Q9SIP7 & $4 \mathrm{~S}$ ribosomal protein $\mathrm{S} 3$ & -1.5 & & \\
\hline BeG3N5H6 & P5288 & $6 \mathrm{~S}$ ribosomal protein $\mathrm{L} 3-1$ & -1.3 & & \\
\hline BeG3N5A5 & & translational activator GCN1, putative & -6.8 & & \\
\hline BeG9N16F8 & & methionine aminopeptidase [Schizosaccharomyces & -7.2 & & \\
\hline \multicolumn{6}{|c|}{ Transdução de Sinal } \\
\hline BeE6C14H8 & Q886H3 & Sensor histidine kinase & -9.8 & & \\
\hline BeG3N17E1 & & serine/threonine protein kinase FSK [Cryptococcus & -19.8 & & \\
\hline BeG3N7D9 & & $\begin{array}{l}\text { histidine acid phosphatase, IP6 and IP7 kinase, inositol pyrophosphate } \\
\text { synthase, putative [Candida dubliniensisputative; }\end{array}$ & -25.8 & & \\
\hline BeNSVP7F1 & & cAMP-dependent protein kinase regulatory subunit [Blastocladiella & -1.4 & & \\
\hline \multicolumn{6}{|c|}{ Estrutura Celular / Microtúbulos } \\
\hline BeE6N13F3 & & beta-tubulin [Blastocladiella emersonii] & -1.5 & $\uparrow$ & \\
\hline BeE9N19F3 & Q8WXX & Ciliary dynein heavy chain 7 & -9.3 & & $\downarrow$ \\
\hline \multicolumn{6}{|c|}{ Transcrição / Processamento de RNA } \\
\hline BeZSPN17G9 & Q8BU5 & DNA-directed RNA polymerases III $12.5 \mathrm{kDa}$ & -43.1 & $\downarrow$ & \\
\hline BeG12N19C7 & & RNA polymerase II largest subunit [Blastocladiella emersonii] & -26.2 & & $\downarrow$ \\
\hline Q88LS5 & & Transcriptional regulator, LysR family & -14.4 & & \\
\hline \multicolumn{6}{|c|}{ Transporte } \\
\hline BeG12N15C5 & & $\mathrm{H}+/$ nucleoside cotransporter & -23.6 & & \\
\hline BeG9N7C1 & Q8TGD1 & tricarboxylate carrier, putative & -5.8 & $\uparrow$ & \\
\hline \multicolumn{6}{|c|}{ Outros } \\
\hline BeE9N6H3 & Q81CV & Hydrolase & -29.5 & $\downarrow$ & $\downarrow$ \\
\hline BeE9N12E11 & Q8DCG4 & Predicted Zn-dependent proteases & -8.0 & & \\
\hline BeZSPN14G4 & & FAD-dependent oxidoreductase & -8.6 & & \\
\hline
\end{tabular}




\begin{tabular}{|c|c|c|c|c|c|}
\hline BeE9N2G7 & & mitochondrion organization and biogenesis-related protein & -24.4 & & \\
\hline BeG3N13E7 & & ATP-dependent RNA helicase & -1.3 & & \\
\hline BeZSPN18A12 & Q9NUN7 & Alkaline phytoceramidase & -24.8 & & $\downarrow$ \\
\hline BeE6N6E1 & Q7TPT3 & Exocyst complex component 7 & -14.5 & & \\
\hline BeG9N16H4 & Q9BUH4 & similar to Serine/threonine-protein kinase 16 & -7.1 & & \\
\hline BeG9N6G2 & & oxidoreductase, acting on the $\mathrm{CH}-\mathrm{CH}$ group of donors & -14.3 & & $\downarrow$ \\
\hline BeE9N12C6 & Q88E1 & Filamentous hemagglutinin, intein-containing & -12.4 & & \\
\hline BeE9N21D6 & & aminomethyltransferase family protein & -6.6 & & \\
\hline BeG3N19H5 & & hypothetical protein & -6.8 & & \\
\hline BeE6C12B7 & Q913X9 & Probable siderophore receptor & -1.9 & & \\
\hline BeG3N16C3 & & leucine rich repeat (LRR) protein & -3.5 & & \\
\hline BeNSVP4C6 & P19727 & Minor capsid protein 1B & -5.5 & & \\
\hline BeE9D17A8 & Q7ZY47 & ATP-dependent RNA helicase DDX42 & -4.8 & $\downarrow$ & \\
\hline BeZSPN12G2 & & GTP-binding family protein & -8.6 & & $\uparrow$ \\
\hline BeE6C16F1 & Q8XQU5 & short chain dehydrogenase [Plesiocystis & -8.9 & & \\
\hline BeE6C4B1 & & putative secreted protein [Xanthomonas & -7.9 & & \\
\hline BeG3N3F11 & P4493 & Hypothetical 39.4 kDa protein & -7.4 & & \\
\hline BeG3N13D9 & & mitochondrial import receptor subunit tom2 & -23.9 & & \\
\hline & & No Match & & & \\
\hline BeE6C3D7 & & No match & -44.3 & $\downarrow$ & \\
\hline BeG9N1E4 & & No match & -12.5 & $\downarrow$ & \\
\hline BeG3N14H11 & & No match & -9.7 & & \\
\hline BeG6N17C11 & & No match & -6.5 & & \\
\hline BeG6N2C11 & & No match & -22.9 & & $\downarrow$ \\
\hline BeG6N14D7 & & No match & -14.3 & & $\uparrow$ \\
\hline BeG12N17C3 & & No match & -11.4 & & \\
\hline BeG3N14E3 & & No match & -20.0 & & \\
\hline BeG3N7D1 & & No match & -9.5 & & $\downarrow$ \\
\hline BeG9N15D8 & & No match & -8.6 & & \\
\hline BeG3N9G12 & & No match & -26.7 & & \\
\hline BeG6N15C2 & & No match & -8.5 & & \\
\hline BeG3N2E1 & & No match & -18.9 & & \\
\hline BeZSPN9A7 & & No match & -7.1 & & \\
\hline BeE12N28D5 & & No match & -14.7 & $\downarrow$ & \\
\hline BeE9N21C6 & & No match & -1.8 & & \\
\hline BeZSPN18D4 & & No match & -29.5 & $\downarrow$ & \\
\hline BeG3N7F11 & & No match & -5.8 & & \\
\hline BeG9N12A4 & & No match & -6.9 & & \\
\hline BeE6N1B4 & & No match & -1.7 & $\uparrow$ & \\
\hline BeG6N2F4 & & No match & -13.6 & & $\downarrow$ \\
\hline BeE3N6F5 & & No match & -2.3 & & \\
\hline BeG3N8F1 & & No match & -11.9 & & \\
\hline BeG3N9B8 & & No match & -7.3 & & \\
\hline BeG3N8B1 & & No match & -6.7 & & \\
\hline BeE6C5A1 & & No match & -8.8 & $\downarrow$ & \\
\hline BeG3N6B1 & & No match & -11.3 & & \\
\hline BeE9D14D7 & & No match & -1.9 & $\uparrow$ & \\
\hline BeE6N6F3 & & No match & -7.6 & & \\
\hline BeG3N1E6 & & No match & -7.4 & & \\
\hline BeG9N8D5 & & No match & -1.6 & $\downarrow$ & \\
\hline BeG9N19E8 & & No match & -9.4 & & \\
\hline BeG6N1B2 & & No match & -7.6 & & \\
\hline BeG9N1F9 & & No match & -7.2 & & \\
\hline BeG6N17F7 & & No match & -8.6 & & $\downarrow$ \\
\hline BeG9N21H2 & & No match & -5.7 & & \\
\hline BeNSVP4A6 & & No match & -1.7 & $\downarrow$ & \\
\hline BeG3N2A4 & & No match & -11.7 & & \\
\hline BeG3N16D8 & & No match & -8.4 & & \\
\hline BeG9N9A3 & & No match & -6.5 & & \\
\hline BeG3N2F4 & & No match & -2.3 & & \\
\hline BeG9N14A8 & & No match & -22.6 & & \\
\hline BeG9N14F4 & & No match & -1.9 & & \\
\hline
\end{tabular}




\begin{tabular}{|c|c|c|c|c|}
\hline BeZSPN15A6 & No match & -6.0 & & \\
\hline $\mathrm{BeG} 3 \mathrm{~N} 2 \mathrm{H} 3$ & No match & -7.5 & & \\
\hline BeNSVP9H6 & No match & -5.7 & $\downarrow$ & \\
\hline BeE6N18B7 & No match & -1.4 & $\uparrow$ & \\
\hline BeE6H8F12 & No match & -1.7 & $\uparrow$ & \\
\hline BeNSVP7G2 & No match & -1.4 & & \\
\hline BeG9N22E3 & No match & -5.2 & & \\
\hline BeG9N3F11 & No match & -9.7 & & \\
\hline BeZSPN3E6 & No match & -6.6 & & \\
\hline BeZSPN7G9 & No match & -6.7 & & $\uparrow$ \\
\hline BeG3N9D6 & No match & -6.6 & & \\
\hline BeG3N14E4 & No match & -5.3 & & $\downarrow$ \\
\hline BeG6N3F1 & No match & -14.3 & & \\
\hline BeG9N8A4 & No match & -6.3 & & \\
\hline BeG6N15D8 & No match & -8.3 & & \\
\hline BeZSPN13H1 & No match & -13.3 & & \\
\hline BeZSPN8E5 & No match & -4.7 & & \\
\hline
\end{tabular}




\section{SÚMULA CURRICULAR}

Nome: César Moisés Camilo

Local e data de nascimento: Guarulhos, SP, 10 de fevereiro de 1982

\section{Educação:}

Ensino Médio:

Colégio Integrado - Rio Claro/SP

1997 a 1999

\section{Graduação:}

Universidade de São Paulo - Faculdade de Ciências Farmacêuticas - São Paulo/SP Farmácia e Bioquímica (Modalidade Análises Clínicas e Toxicológicas) 2000 a 2005

\section{Ocupação:}

2001 a 2002 - Bolsista de Iniciação Científica PIBIC-CNPq - Faculdade de Ciências Farmacêuticas, Departamento de Análises Clínicas e Toxicológicas - USP

2002 a 2003 - Bolsista de Iniciação Científica FIPFARMA - Faculdade de Ciências Farmacêuticas, Departamento de Análises Clínicas e Toxicológicas - USP

2004 a 2005 - Bolsista de Iniciação Científica FAPESP - Instituto de Química, Departamento de Bioquímica - USP

2005 a 2009 - Bolsista de Doutorado Direto CAPES - Instituto de Química, Departamento de Bioquímica - USP

\section{Publicações:}

\section{$\underline{\text { Artigos Completos }}$}

Camilo, C.M.; Assunção, N.A.; Bechara, J.H.E; Gomes, S.L. "Transcriptomic and metabolic response of Blastocladiella emersonii to hypoxia and transient anoxia" (Manuscrito em preparação).

Salinas, R.K.; Camilo, C.M.; Tomaselli, S.; Valencia, E.Y.; Farah, C.S.; El-Dorry, H.; Chambergo, F.S. "Solution structure of the C-terminal domain of multiprotein bridging factor 1 (MBF1) of Trichoderma reesei." Proteins, v. 75, p. 518-523, 2009. 
Salinas, R.K.; Camilo, C.M.; Farah, C.S.; El-Dorry, H.; Chambergo, F.S. "1H, 15N and 13C backbone NMR assignments of a multiprotein bridging factor 1 from Trichoderma reesei (TrMBF1, 56-159).” Activity Report (Laboratório Nacional de Luz Síncrotron), v. 1, p. 1-2, 2006.

Salazar, P.M.N.; Ropke, C.D.; Camilo, C.M.; Freitas, P.C.D.; Barros, S.B.M. "Avaliação por análise fatorial das condições da extração do 4-nerolidilcatecol de Pothomorphe umbellata (L). Miq.” RBCF. Revista Brasileira de Ciências Farmacêuticas, v. 41, n. 2, p. 261-269, 2005.

Ropke, C.D.; Ostrosky, E.A.; Kaneko, T.M.; Camilo, C.M.; Sawada, T.C.H.; Barros, S.B.M. "Validação de metodologias analíticas para determinação quantitativa de alfa-tocoferol e 4-nerolidilcatecol." RBCF. Revista Brasileira de Ciências Farmacêuticas, São Paulo/SP, v. 39, n. 2, p. 209-217, 2003.

\section{$\underline{\text { Resumos em Congressos }}$}

CAMILO, C. M. ; GOMES, S.L. . Transcriptional response of the chytridiomycete Blastocladiella emersonii to hypoxia and transient anoxia: evidence of a regulatory mechanism similar to the mammalian HIF-1 pathway. In: FEMS - 3rd Congress of European Microbiologists, 2009, Gothenburg.

SALINAS, R. K. ; CAMILO, C. M. ; TOMASELLI, S. ; FARAH, S. C. ; EL-DORRY, H. ; CHAMBERGO, F. S. . The Solution Structure of the C-terminal Domain of a Multiprotein Bridging Factor 1 (MBF1) of Trichoderma reesei. In: 49th ENC Experimental Nuclear Magnetic Resonance Conference, 2008, Pacific Grove, California

CAMILO, C. M. ; EL-DORRY, H. ; GOMES, S.L. . TRANSCRIPTIONAL RESPONSE TO HYPOXIA AND TRANSIENT ANOXIA IN THE AQUATIC FUNGUS BLASTOCLADIELLA EMERSONII. In: 33rd FEBS Congress \& 11th IUBMB Conference, 2008, Atenas.

CAMILO, C. M. ; EL-DORRY, H. ; GOMES, S.L. . TRANSCRIPTIONAL RESPONSE OF THE AQUATIC FUNGUS BLASTOCLADIELLA EMERSONII TO HYPOXIA AND TRANSIENT ANOXIA. In: XXXVI Reunião Anual da SBBq e 10th IUBMB Conference, 2007, Salvador.

SALINAS, R. K. ; CAMILO, C. M. ; FARAH, S. C. ; EL-DORRY, H. ; CHAMBERGO, F. S. . NMR STUDIES ON THE STRUCTURE OF THE C-TERMINAL DOMAIN FROM A MULTIPROTEIN BRIDGING FACTOR (TRMBF1) FROM TRICHODERMA REESEI. In: XXXVI Annual Meeting of the SBBq and 10th IUBMB Conference, 2007, Salvador.

CAMILO, C. M. ; CHAMBERGO, F. S. ; EL-DORRY, H. . Cloning, heterologous expression and purification of transcription factors from Trichoderma reesei. In: XXXV Reunião Anual da SBBq, 2006, Águas de Lindóia.

SALINAS, R. K. ; CAMILO, C. M. ; FARAH, S. C. ; EL-DORRY, H. ; CHAMBERGO, F. S. . NMR studies of a multiprotein bridging factor (TrMBF1) from Trichoderma reesei and its interaction with TATA binding protein (TrTBP). In: XXXV Reunião Anual da SBBq, 2006, Águas de Lindóia. 